\author{
UNIVERSIDADE DE SÃO PAULO \\ FACULDADE DE FILOSOFIA, LETRAS E CIÊNCIAS HUMANAS \\ DEPARTAMENTO DE HISTÓRIA \\ PROGRAMA DE PÓS-GRADUAÇAO EM HISTÓRIA SOCIAL
}

\author{
ANDRÉ OLIVA TEIXEIRA MENDES
}

Os Documentos interessantes para a história e costumes de São Paulo: subsídios para a construção de representações 


\section{UNIVERSIDADE DE SÃO PAULO \\ FACULDADE DE FILOSOFIA, LETRAS E CIÊNCIAS HUMANAS \\ DEPARTAMENTO DE HISTÓRIA \\ PROGRAMA DE PÓS-GRADUAÇAO EM HISTÓRIA SOCIAL}

Os Documentos interessantes para a história e costumes de São Paulo: subsídios para a construção de representações

Dissertação apresentada ao Programa de

Pós-Graduação em História Social da Faculdade de Filosofia, Letras e Ciências Humanas da Universidade de São Paulo, para a obtenção do título de Mestre.

Orientação: Prof ${ }^{a}$. Dr ${ }^{\text {a }}$ Zilda M. G. Iokoi 
A César Martins, sobretudo por sua amizade. Ao Arquivo do Estado, local de guarda da documentação pública paulista e de visitação imprescindível por todos aqueles que se dedicam à história. Aos meus alunos, especialmente os da rede pública, por tudo o que me ensinaram. 


\section{Resumo}

Deste o séc. XIX os arquivos vêm se consolidando, pelo menos no imaginário popular, como verdadeiros celeiros da história. No entanto, cabe ao pesquisador munir-se de um repertório cada vez mais eficiente para lidar com esses acervos, especialmente no que diz respeito ao caráter de representação (sob a perspectiva de Henri Lefebvre) expresso tanto em sua constituição quanto na disponibilização do material a ser utilizado pelo público pesquisador. Assim, a intenção desse trabalho é mostrar como o Arquivo Público de São Paulo responsabilizou-se por estabelecer uma determinada imagem do passado paulista especialmente por meio de uma de suas publicações: os Documentos interessantes para a história e costumes de São Paulo.

Criado como um órgão ligado diretamente à administração pública, a Repartição de Estatística e Arquivo (1892) incumbiu-se de recolher, selecionar, transcrever e disponibilizar um repertório significativo de documentos acerca do passado administrativo de São Paulo, vinculando-se com outras instituições, como o IHGSP (Instituto Histórico e Geográfico de São Paulo) e o Museu Paulista, responsáveis por construir uma representação elitista do pioneirismo bandeirante, fosse por meio das análises documentais realizadas, fosse pelo estabelecimento de critérios para a seleção e descarte de documentos de seu acervo.

Assim, essa dissertação quer demonstrar como a Repartição de Arquivo em seu vínculo com as instituições citadas acima, atuou, através de sua coleção Documentos Interessantes, como agente efetivo na construção de uma representação conservadora sobre a formação de São Paulo, levando à elaboração de uma representação da própria Repartição e de seu papel diante da sociedade civil.

Palavras-chave: historiografia, história de São Paulo, Arquivo Público de São Paulo, teoria das representações, arquivologia. 


\begin{abstract}
Since the 19th Century, Archives have been turning, at least in the popular imaginary, as real deposits of history. Nevertheless, it is the researcher's responsibility to acquire an efficient repertory to deal with these files, especially concerning representation (according to Henri Lefebvre's perspective) expressed in both their constitution and their availability to the research public. From this perspective, this work aims at showing how São Paulo Public Archives determined a certain image of the past of the city mainly through a publication called $O s$ Documentos interessantes para a história e costumes de São Paulo. (Interesting Documents for History and Customs of São Paulo).

Created as an institution, directly linked to the public administration, Repartição de Estatística e Arquivo (1982) assumed the functions of collecting, selecting, transcribing and making available a significant repertory of documents about the administrative past of São Paulo. Working in collaboration with other institutions such as, IHGSP (Instituto Histórico e Geográfico de São Paulo) and Museu Paulista, they built and elitist representation of the pioneers Bandeirantes by means of documental analysis; selection and rejection of documents in the archives.

This dissertation intends to show how Repartição de Arquivo, together with the other institutions, using the collection Documentos Interessantes, acted as effective agents in the construction of a conservative representation of São Paulo formation, leading to the delineation of the Repartição itself, and its role in the civil society.
\end{abstract}

Keyword: historiography, São Paulo History, São Paulo Public Archives, representation theories, archivology. 


\section{Agradecimentos}

Desde que me conheço como leitor nunca gostei de ler os "Agradecimentos" feitos pelo autor em seu trabalho. Acho mesmo que li apenas três deles, e por razões muito pessoais. A minha impressão era que se tratava de algo piegas, não mais que adulação desnecessária ou mera "burocracia" acadêmico-familiar. Ledo engano... Talvez fruto da minha arrogância e total ignorância.

Com o término desse trabalho, cuja qualidade será avaliada pela banca examinadora, senti uma enorme necessidade de agradecer a todos aqueles que de alguma forma contribuíram para sua execução, quase como um tributo às pessoas que, mesmo sem a menor idéia, acabaram por permitir que essa dissertação chegasse ao fim. São professores, familiares, amigos, colegas que, de um lado, entenderam as ausências (que poderiam parecer descaso), as conversas monotemáticas, a teimosia (travestida de convicção), a irritação quase gratuita... E, de outro, contribuíram com “orientações" paralelas, indicações bibliográficas imprescindíveis, leituras críticas, correções, discussões acaloradas, sempre acompanhadas de muito carinho.

Aos amigos Ana Maria e Zilton deixo registrado todo o meu apreço. Obrigado pelas noites de sábado, sempre regadas a boas conversas (e não apenas isso), que transitavam sobre os mais diversos assuntos, menos no tema da minha dissertação (ainda bem!). Agradeço também a Ana Lúcia Rodrigues que, além de amiga, foi responsável pela digitação de parte significativa dos registros dos Documentos interessantes disponíveis em anexo nesse trabalho.

Formado desde 1995, nunca passou pela minha cabeça realizar um trabalho acadêmico que visasse titulação. Não se trata de descaso com o fazer pesquisa, nem mesmo a pretensão de imaginar-me já plenamente formado, pois sempre achei que a busca e o trato com as fontes documentais seriam elementos imprescindíveis ao exercício da profissão de professor, sendo mesmo impossível dissociá-las. Porém, fui distanciando-me da universidade por vontade própria e a reaproximação foi lenta 
e por vezes dolorosa. Nesse quesito tenho muito a agradecer a algumas pessoas. A primeira delas é a Prof ${ }^{a}$. Dra . Zilda Iokoi que, mesmo conhecendo-me desde 1992 não tinha maiores motivos para aceitar a orientação de um trabalho como esse, a não ser por uma dose demasiada de confiança, fruto de sua experiência profissional e do grande carinho mútuo, além de algumas indicações oriundas de amigos comuns. A ela devo o meu respeito e a mais profunda gratidão, seja por seu jeito agridoce no trato, ou por sua leitura acurada e precisa de tudo aquilo que eu ousava entregar, mesmo passando por momentos pessoais difíceis. Quero deixar aqui registrado que ela faz parte da minha vida e sempre estaremos juntos, mesmo que o destino aparentemente nos afaste.

Aproveito ainda para agradecer a uma querida amiga. Professora das melhores que conheço, sempre dedicada e preocupada com o ofício, Ciça Martinez juntamente com Lourdes, minha mãe, talvez tenham sido as pessoas que mais insistiram, quase à exaustão, para que esse trabalho tivesse início, participando de tudo, desde a apresentação do projeto. É certo que sem elas esse mestrado não existiria.

Como imagino ser natural, no decorrer desses anos, dúvidas foram surgindo sobre o tema, sua relevância, a qualidade do que eu lia ou como escrevia. Nesse cenário tive a sorte de conviver com pessoas como Claudia Moraes, Cristina Soto e Hélio Braga, além da própria Ciça, que sempre se mostraram dispostas à troca de idéias e apreciação crítica, ao incentivo e encorajamento. A elas serei sempre grato.

Aos colegas do grupo de estudos mantidos pela professora Zilda junto ao LEI (Laboratório de Estudos sobre a Intolerância), especialmente a Sandra Nunes, por todas as discussões e opiniões diversas, acompanhadas por muitas risadas e café nas tardes de sexta-feira.

Em relação ao início do processo que culminou nessa dissertação, devo registrar toda a minha consideração ao Prof. Dr. José Carlos Sebe. Ele foi ele o responsável por permitir e conduzir minha "entrada" no mundo acadêmico, sendo meu orientador de Iniciação Científica, ainda em 1994. Posso afirmar que, se de 
alguma forma tornei-me um historiador com o mínimo de preocupação em relação à sistematização e leitura de documentos, certa parcela de "culpa" é dele.

Aos profissionais do Arquivo do Estado de São Paulo que, apesar das mudanças de nome e subordinação, continuará sempre a ser conhecido carinhosamente por aqueles que por lá passaram apenas por Arquivo. A Lauro Ávila Pereira e Simone Lucena Cordeiro meus profundos agradecimentos por tudo o que fizeram quanto ao meu acesso ao acervo. Espero não ter sido um consulente muito chato.

Meus agradecimentos também aos Profs. Drs. Ana Maria de Almeida Camargo e Odair da Cruz Paiva, presentes em minha banca de qualificação. Se à primeira vista esse trabalho não refletiu a totalidade de suas indagações, sugestões, críticas e comentários, todos eles estiveram, no entanto, presentes, "assombrandome" em cada momento desde junho de 2009. Assumo por completo qualquer falha nesse sentido. Espero poder contar sempre com a ajuda deles.

Aproveito também para agradecer aos professores Luiz Carlos de Azevedo, pai e filho. Pode parecer bobagem, mas para quem não pensava em seguir carreira acadêmica, ser aceito com professor universitário talvez tenha sido um dos maiores elementos de "pressão" para que tudo isso ocorresse. Mais uma vez devo agradecer à Cristina Soto, pois partiu dela a aposta e o convite para que eu ingressasse no ensino superior.

Propositalmente deixei para o final os agradecimentos a algumas pessoas. Não se tratou de descaso, mas sim uma dose de incompetência para mensurar em palavras a relevância que elas têm na minha vida e tiveram no desenvolvimento desse trabalho. Trata-se de Luiz, Lourdes, Daniela e Silvia que, certamente, são as pessoas mais importantes com quem convivo, mesmo que por vezes eu insista em não demonstrar.

Como filho de professores, devo a Luiz e Lourdes, cada um à sua maneira, todo o gosto e respeito que tenho pela minha profissão. Se coube a minha mãe ensinar-me a estudar, foi meu pai que direcionou minhas leituras, devido ao seu 
amor e dedicação aos temas da história. Se algum mérito tenho naquilo que faço em sala de aula, devo a eles.

Contudo, desde muito cedo tive que aprender a "dividir" as atenções deles devido à presença de minha irmã Daniela. Diametralmente oposta a mim em muitos aspectos, tornou-se minha principal "oponente" em algumas brigas memoráveis. Ainda bem que foi assim, caso contrário teria sido uma vida muito sem graça. Dizer que não contribuiu diretamente para a execução desse trabalho seria desfaçatez, pois ela sempre esteve lá, pronta para ajudar e dar suporte afetivo no que fosse possível. O que sou devo, em parte, a ela também. Se à primeira vista não parece muito, posso garantir que para mim isto foi, e será sempre, imprescindível.

Quanto à Silvia, o que dizer para externar gratidão e amor? Desse último rol de agradecimentos é a pessoa com quem há menos tempo convivo e talvez seja a que mais conheço. Companheira, leitora minuciosa, pesquisadora refinada e historiadora como poucos. Sou-lhe grato por fazer parte da minha vida, mesmo que essa convivência seja o "fardo" da dela. Sou incapaz de imaginar-me sem sua presença e opiniões tão divergentes das minhas (ainda bem!).

A todas essas pessoas reafirmo uma vez mais minha gratidão, esperando que um dia possa retribuir à altura. Ao leitor fica a esperança que este texto não tenha ficado parecido com um daqueles agradecimentos que eu mesmo nunca gostei de ler. 


\section{SUMÁRIO}

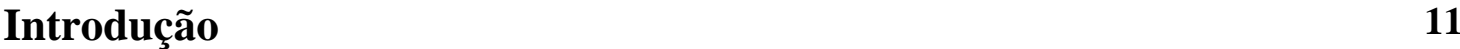

Capítulo 1- O desenvolvimento urbano de São Paulo e a construção de 35 sua identidade

Capítulo 2- O Arquivo do Estado e seus Documentos interessantes para a história e costumes de São Paulo

Capítulo 3- Os arquivos e seus dilemas: memória, patrimônio e representações

Capítulo 4- Considerações finais 202

Referências $\quad 209$

Anexos

I- Relação de títulos dos Documentos interessantes 222

II- Relação de títulos do Boletim do Departamento do Arquivo do Estado 223

III- Base de dados com todos os registros dos Documentos interessantes 224 


\section{Introdução}

Nas últimas décadas muito tem sido dito e escrito acerca das dificuldades e importância do ofício do historiador. Estudar o passado, (re)construindo-o constantemente, de acordo com as orientações teórico-metodológicas de cada pesquisador em seu tempo, bem como o uso dado às fontes documentais, implicam necessariamente assumir determinadas posições políticas, em uma clara demonstração da impossibilidade de manter-se neutro diante de um suposto "passado intocado", pronto para ser "resgatado". Exercitar a escrita da história mostra-se, cada vez mais, uma tarefa árdua, responsável por estabelecer um determinado vínculo entre os "mortos e os vivos". Assim, o presente assume posição de destaque quanto às escolhas feitas para essa compreensão, estabelecendo-se verdadeiro método progressivo-regressivo em que as preocupações e anseios próprios do presente condicionam e delimitam o retorno ao passado. Nas palavras de Lucien Febvre, a "História é filha de seu tempo", na medida em que o indivíduo percebe apenas o que lhe é permitido, de acordo com seu estrito mundo mental ${ }^{1}$. Em relação ao passado, seria proibido "conhecer de si qualquer coisa a não ser o que ele mesmo lhes fornece, [conscientemente ou não]", cabendo ao historiador preocuparse com a posição "humilhante" que ocupa na fila de transmissão das informações ao longo do tempo ${ }^{2}$.

Não sendo capaz de recompor o passado por meios encantatórios, caberia ao historiador buscar elementos que permitissem a ele estabelecer determinadas explicações aos seus questionamentos, utilizando-se de resíduos ou indícios de tempos históricos distintos e simultâneos. Marc Bloch defendia a tese de que seria impossível fazer história daquilo que não deixou vestígios, e se fosse esse o caso,

\footnotetext{
${ }^{1}$ BLOCH, Marc. Apologia da história, ou o ofício do historiador. Rio de Janeiro, Jorge Zahar Editor, 2001, p. 67.

${ }^{2}$ Idem, p.75.
} 
caberia tanto aos historiadores como ao grupo social ao qual ele pertencesse, resignarem-se à ignorância ${ }^{3}$.

A própria escolha de quais vestígios estudar, em detrimento de outros, mostra-se um ato repleto de parcialidades, num exercício ativo de construção de seu entendimento do passado a partir do hoje, na medida em que seus parâmetros analíticos são forjados no mundo do vivido, elegendo-se os problemas que mereçam ser respondidos, transformando possíveis documentos em fontes.

Sendo assim, a intenção desta dissertação é mostrar de que maneira instituições de guarda documental, em especial o caso do Arquivo do Estado de São Paulo, tiveram um papel preponderante na construção de determinadas imagens e identidades, especialmente a paulista, fosse pelo posicionamento ideológico de muitos de seus membros, fosse pelo caráter técnico de muitas das suas intervenções de descarte e seleção de material a ser publicado, atuando como grande receptáculo administrativo e histórico de São Paulo.

O presente trabalho tem por objetivo mostrar, por meio da análise da série Documentos interessantes para a história e costumes de São Paulo, como a escolha de determinados conjuntos documentais permitem a (re)construção constante de representações diversas sobre um determinado passado, seja na sua atuação junto à produção historiográfica, seja dentro da própria instituição arquivística, responsável por selecionar e publicar documentos tidos como historicamente relevantes. Assim, esse mecanismo atuaria como forma de (re)afirmação de estruturas conservadoras de poder, retomando constantemente o posicionamento sócio-político de determinados grupos sociais. Vale aqui um esclarecimento. Devido à extensão temporal abarcada por essa publicação (apesar das interrupções, seus 95 volumes percorrem o período que vai de 1894 a 1990), o recorte desse trabalho restringe-se aos primeiros 43 volumes da série, publicados até 1903, enquanto o Diretor Antonio de Toledo Piza ainda estava vivo e responsável pelo projeto.

\footnotetext{
${ }^{3}$ Como será visto adiante, especificamente no Capítulo III, na opinião de Henri Lefbvre sempre existiriam vestígios de um passado, preservados por meio de seus resíduos.
} 
Cabe ressaltar também, que nos mais de 110 anos de existência oficial do Arquivo do Estado, originalmente chamado de Repartição de Estatística e Arquivo, muito foi mudado quanto à representação que a instituição tinha de si mesma. De um espaço atuante na administração pública, mediante a produção de quadros estatísticos, além de acumulador de documentos em suporte papel, responsável pela preservação de elementos capazes de alimentar uma memória coletiva ligada a um segmento social, tornou-se um órgão que luta por sua efetivação como agente "facilitador" de ações públicas e coletivas, capazes de dar acesso irrestrito a um volume cada vez maior de informações contidas em seus depósitos ${ }^{4}$. O ato de recolher e disponibilizar acervos tem tornado possível a visibilidade a uma massa documental cada vez maior, por muito tempo acumulada nas mais diversas instâncias do poder público paulista ou junto a particulares, fadadas ao desaparecimento, fosse pelo descaso, fosse pelo apego ao sigilo. Nas palavras de Celso Lafer, em uma democracia a coisa pública não se restringe apenas ao que é comum a todos, mas também abarcaria tudo aquilo que é "acessível ao conhecimento de todos"5. Talvez venha desse princípio a incorporação, aos arquivos, da idéia de patrimônio ${ }^{6}$.

Parcela significativa de todo esse processo de reconstrução foi gestada dentro do próprio Arquivo, na medida em que este reelaborou sua auto-imagem e seus procedimentos técnicos, estabelecendo novas prioridades, métodos e ações de divulgação, o que pode ser percebido mediante a análise dos novos cenários da

\footnotetext{
${ }^{4}$ Vale salientar que as funções subsidiárias que ligavam esta instituição às atividades administrativas inerentes ao poder executivo paulista foram sendo retiradas mediante a criação de novas instituições, como o Departamento de Estatística, relegando o Arquivo a uma condição subalterna, e muitas vezes encarada como menos importante.

${ }^{5}$ LAFER, Celso. "O público e o privado: suas configurações contemporâneas para a temática dos arquivos". In: INSTITUTO FERNANDO HENRIQUE CARDOSO. Documentos privados de interesse público: o acesso em questão. São Paulo, IFHC, 2004, p. 34.

${ }^{6}$ Apesar de essa discussão inserir-se em capítulo posterior, vale lembrar que no Brasil os conjuntos arquivísticos não são vistos verdadeiramente pelo poder público ou parcela da sociedade civil como elementos do patrimônio histórico-cultural nacional, tratando-se apenas de um atributo meramente legal. Além disso, vale ressaltar que a elevação de determinado conjunto documental a essa "categoria" implica em escolhas feitas a partir de critérios os mais diversos, longe de um suposto espírito de neutralidade, mas próximo a determinadas escolhas ideológicas que acabam por "restringir" o acesso à informação, e "obrigando" o pesquisador a voltar-se às possíveis brechas resistentes.
} 
produção historiográfica. Em hipótese alguma este trabalho tem por intuito atribuir ao Arquivo do Estado de São Paulo o pioneirismo nesta área. Tal característica mostrou-se uma constante em todo o mundo ocidental, especialmente durante a virada do séc. XIX para o séc. XX, quando instituições congêneres ganharam força e espaço junto à sociedade, fornecendo importantes subsídios para a construção de suas (re)interpretações históricas, possibilitando verdadeiros "resgate" por parte dos pesquisadores.

Visando uma análise mais objetiva, neste trabalho optou-se por utilizar, prioritariamente, a publicação Documentos interessantes por ter sido esta uma obra que durante muito tempo foi vista como referência para um grupo de historiadores, especialmente àqueles ligados ao Instituto Histórico e Geográfico de São Paulo (IHGSP) ${ }^{7}$, na medida em que "facilitava" seus trabalhos de pesquisa, organizando e publicizando suas fontes potenciais. Trata-se de uma série capaz de retratar como conjuntos documentais permitiram, e permitem ainda, a construção de determinadas representações históricas, mesmo após terem passado por processo de avaliação e descarte $^{8}$, ou mesmo quando sua manutenção/publicação não levou em conta princípios como os de organicidade, fundamental na composição de qualquer conjunto documental arquivístico na atualidade. Em muitos casos os critérios alegados por seus editores para a seleção e escolha dos documentos a serem publicados estavam relacionados ao risco de perda e obscuridade de "importantes e preciosos" documentos históricos, fosse pelo precário estado de conservação do material, fosse pelo descaso a que fora entregue a documentação durante várias décadas ${ }^{9}$.

\footnotetext{
${ }^{7}$ Para maiores informações sobre a proximidade de ações existente entre o Arquivo do Estado e o IHGSP, ver o Capítulo I.

${ }^{8}$ A esse respeito, o presente trabalho dedicou uma de suas partes. Para maiores informações, ver Capítulo III.

${ }^{9}$ Apesar do precário estado de conservação dos documentos ser apresentado como uma constante, também são comuns as referências que indicam a origem dos documentos como estando em perfeito estado de conservação. Este é o caso do termo de abertura do volume 55, referente às "Correspondência oficial do Capitão General Antonio José da França Horta (1802- 1804)", no qual aparece expressa a informação de que os originais estariam no códice 82 do acervo do Arquivo, em perfeito estado de conservação. AESP. Documentos interessantes. São Paulo, Casa Eclética, 1937, vol. 55, p. 07.
} 
Um dos elementos que motivaram a escolha do tema foi o fato de eu ter trabalhado durante oito anos no Arquivo do Estado e em boa parte desse período não ter muita clareza quanto à função pragmática dessa publicação, apesar da relevância historiográfica que ela assumia. Publicar transcrições de documentos que, em tese estariam sob a guarda do próprio Arquivo, sem dar ao pesquisador a posição física dos originais, parecia uma atitude pouco eficiente, e tecnicamente questionável. Inúmeras tentativas de localização dos documentos publicados acabaram fracassando, apesar de alguns indícios da existência de trabalhos técnicos efetuados na própria instituição, fazendo com que muitos dos documentos transcritos na publicação assumissem o papel de originais, autênticos e fidedignos. Além disso, ficava a dúvida quanto aos critérios utilizados na própria seleção daquilo que seria efetivamente interessante para seus editores.

Apesar das críticas, considero que todo o apego aos documentos apresentado nesse tipo de publicação reflete diretamente os princípios teórico-metodológicos estabelecidos pela chamada escola metódica, responsáveis por nortear iniciativas semelhantes em diversas partes do mundo ocidental, além de orientar a formação acadêmica de um grande conjunto de historiadores. Para José Honório Rodrigues,

a "palavra documentum, de uso mais generalizado que fonte, vem do verbo docere, ensinar, mostrar indicar. O Documento é, assim, entendido como fonte escrita, meio de conhecimento, de algum fato ou ato ali representado" 10 .

Tal representação ainda é muito forte, especialmente junto ao público "leigo", e talvez venha daí o maior desafio para aqueles que acolheram o fazer história como profissão. Mostra-se cada vez mais necessário religar a história à formação do indivíduo, passando a ser vista não como culto aos mortos, mas como manifestação efetiva de vida.

\footnotetext{
${ }^{10}$ WITTER, José Sebastião. Arquivo e história. O Arquivo do Estado de São Paulo na administração e na história. Tese de Livre Docência apresentada na FFLCH da Universidade de São Paulo, 1981, p. 39.
} 
A melhor forma para revalorização do passado seria conhecê-lo e assim, deixar de enaltecer o episódico e a peça museal estática em nome de uma relação mais dinâmica e orgânica.

Nesse cenário, o Arquivo do Estado apresentar-se-ia como uma instituição típica por ser ela detentora de inestimável acervo documental, capaz de fornecer subsídios importantes para estudiosos, mas contando com pouco, ou nenhum, reconhecimento das estruturas administrativas governamentais, ou mesmo de parcela significativa da opinião pública. Assim, nas palavras de José Sebastião Witter,

\begin{abstract}
"a procura do entendimento do papel efetivo, dos Arquivos, como elemento de retaguarda da máquina governamental, como guardião de documentação transitória e como depósito de cultura permanente, poderá criar condições para que eles ocupem a verdadeira e correta posição dentro da vida nacional, estadual e municipal"11.
\end{abstract}

Apenas para ilustrar tal situação, em relatório apresentado pelo Secretário do Interior, Gustavo de Oliveira Godoy (1907) apontava para as boas condições de salubridade e higiene presentes em São Paulo devido ao baixo coeficiente de óbitos registrados, não excedendo " 21 por 100"12.

Se por um lado os trabalhos efetuados pela antiga Repartição de Estatística e Arquivo atendiam aos anseios administrativos do Estado, por outro a preocupação em publicar repertórios de fontes documentais mostrava-se uma constante nas atividades subsidiárias da instituição. Para Theodore Schellenberg, os historiadores tiveram papel fundamental na criação/fortalecimento dos arquivos pois,

"compreendendo o valor das fontes documentais, começaram a agir junto aos governos a fim de proteger e tornar acessível uma das principais fontes, qual seja a dos documentos públicos" $" 13$.

\footnotetext{
${ }^{11}$ Idem, p. 74.

${ }^{12}$ GOVERNO DE SÃO PAULO. Relatório da Secretaria dos Negócios do Interior. São Paulo, Tipografia do Estado de São Paulo, 1907, p. 64.

${ }^{13}$ SCHELLENBERG, Theodore R. Arquivos modernos: princípios técnicos. Rio de Janeiro, FGV, 2002, p. 335.
} 
A contra partida institucional viria com a disponibilização de instrumentos de pesquisa e publicações de coleções, servindo de estímulo às futuras investigações.

Tal iniciativa encontrou eco em diversas instituições européias. Na Itália, Ludovico Antonio Muratori, conservador dos arquivos de Modena, publicou o Rerum italicarium scriptors (1723-38), com 28 volumes. Seguindo a mesma linha, na Alemanha foi editado o Monumenta Germaniae Histórica (iniciada em 1826), dedicando-se ao levantamento de fontes medievais, registradas em 115 volumes. Essa última iniciativa foi fruto de uma ação incentivada pela Sociedade Histórica Alemã, tendo como grande orientador George Heinrich Putz, bibliotecário em Hanover e Berlim. Na Inglaterra foi organizado o Rerum Britannicarum mediiaevi scriptores (1858-1911). Em todos eles, apesar de terem suas origens vinculadas ao financiamento particular, cada vez mais o poder público passou a ocupar essa função, orientando as linhas e critérios de seleção e divulgação.

No caso paulista dos Documentos interessantes, a série atenderia às necessidades de uma legítima publicação documentária na medida em que as reproduções, além de substituírem os originais, trariam agregado um abundante volume de informações explicativas capazes de orientar futuros interpretes da história paulista e nacional ${ }^{14}$.

Na opinião de Schellenberg, os documentos produzidos em sua instância administrativa e acumulados em acervos arquivísticos trariam consigo certo caráter de isenção. A subjetividade seria um elemento de menor relevância na medida em que caberia apenas ao pesquisador, e não à instituição arquivística, determinar o significado dos documentos reproduzidos ${ }^{15}$.

Quanto a isso, a questão apresenta-se como um problema. Inegavelmente, a valoração dos documentos, bem como sua qualificação moral, dá-se mediante análise promovida apenas pelos pesquisadores. Se os documentos foram produzidos visando atender a uma demanda burocrático-administrativa, nada mais correto que

\footnotetext{
${ }^{14}$ Esse é especialmente o caso dos primeiros 43 volumes, organizados e publicados sob a orientação do então Diretor Antonio de Toledo Piza. Para maiores informações, ver Capítulo II.

${ }^{15}$ SCHELLENBERG, T. R. Arquivos modernos. Op Cit., p. 343.
} 
encará-los como isentos, visto precederem quaisquer análises. Contudo, não se pode perder de vista que estes mesmos documentos nada mais são que o reflexo cotidiano dos embates e dilemas políticos em voga quando de suas confecções, fruto das disputas de poder de grupos e sua interação com os demais agentes sociais. Assim, esse material não poderia ser visto sob a ótica da neutralidade pois, se precedem as análises, são decorrências de embates políticos. Além disso, a escolha de quais documentos publicar sob a ótica de um interesse único e homogêneo consolidaria um determinado caráter interpretativo, inquestionavelmente distanciado da idéia de isenção.

A publicação de documentos transcritos representaria a possibilidade de disponibilização de catálogos seletivos (o mesmo que repertório), atendendo aos interesses específicos de determinados grupos. Esse tipo de instrumento de pesquisa nada mais seria que um catálogo que toma como unidade básica documentos previamente selecionados, pertencentes a um ou mais fundos ou arquivos, seguindo-se critérios temáticos ${ }^{16}$. Para André Ancona Lopez, esses repertórios "transcendem a dimensão arquivística dos catálogos convencionais", disponibilizando documentos aglutinados por meio de seus temas ${ }^{17}$, fruto de escolhas deliberadas. Apesar de sua aparente importância no que diz respeito ao atendimento aos anseios de determinados grupos de pesquisadores, tais ferramentas não seriam encaradas como obrigações das instituições de guarda, tornando-se responsabilidade dos próprios pesquisadores e, por tanto, dotada de parcialidade.

Esse é o caso específico dos Documentos interessantes. Apesar de ser fruto direto das ações cotidianas de uma instituição pública de guarda documental, tal iniciativa foi levada a cabo, mesmo que com caráter secundário, devido ao engajamento intelectual do Diretor da Repartição, Sr. Antonio de Toledo Piza, com

\footnotetext{
${ }^{16}$ CAMARGO, Ana Maria de Almeida, BELlOTTO, Heloisa Liberalli (coord.). Dicionário de terminologia arquivística. São Paulo, AAB-SP/SEC, 1996, p. 15. No caso específico dos Documentos interessantes, este instrumento não deve ser confundido com um Guia de Fontes pois caberia a este instrumento identificar e localizar fundos, grupos ou séries, de um ou mais arquivos, seguindo-se critérios temáticos ( Idem, p. 42).

${ }^{17}$ LOPEZ, André Ancona. Como descrever documentos de arquivo: elaboração de instrumentos de pesquisa. São Paulo, AESP/ Imesp, 2002.
} 
o IHGSP e sua Revista, fornecendo importantes subsídios para a confecção de análises sobre a história e costumes de São Paulo, balizadas em documentos oficiais, e cujos resultados eram estampados nas páginas desse periódico.

No decorrer dos 11 anos que Toledo Piza ficou à frente da instituição, foram publicados 43 volumes da série (entre 1894 e 1903). O volume 44 (“Diversos"), o primeiro a ser editado após sua morte, e contando com um interregno de 12 anos, teve como característica trazer a público uma "miscelânea" de textos, muitos deles sem nenhuma conexão aparente a uma mesma linha temática. O principal motivo para a adoção desse critério foi que se tratava de documentos selecionados e transcritos pelo próprio Toledo Piza, destinados a uma publicação interrompida com a sua morte. A única contribuição da então direção da Repartição foi a confecção de um texto introdutório e a escolha do último documento transcrito, relativo ao confisco de bens jesuíticos na capitania de São Paulo. Nas palavras do próprio Toledo Piza, em um esboço de texto que deveria servir como introdução ao respectivo volume, tratavam-se de "papéis estranhos ao Arquivo do Estado e a ele recolhidos de várias partes por meus esforços", sendo "um dos mais variados e mais curiosos da coleção" $"$.

Mesmo não pertencendo ao recorte temporal desse trabalho, merece atenção uma leitura um pouco mais detalhada acerca da continuidade da série. Se em um primeiro momento os Documentos interessantes voltaram-se para a publicação de transcrições documentais capazes de atender a uma demanda da elite intelectual e econômica paulista enfeudada no IHGSP, após a morte de Toledo Piza pouco foi alterado. A principal transformação talvez tenha sido a perda de periodicidade da série que, no decorrer de quase uma década, mostrara-se fortemente profícua.

Retomada em 1915, a coleção estendeu-se até o volume 95, editado em 1990, apesar de permanecer suspensa por períodos relativamente longos. Apenas para ilustrar tal situação, o volume 45, o primeiro sem a participação efetiva de Toledo

\footnotetext{
${ }^{18}$ PRADO, Armando. "Antonio de Toledo Piza". In: AESP. Documentos interessantes. São Paulo, Casa Eclética, vol. 44, p. 15.
} 
Piza, veio a público apenas em 1924. Daí em diante, mesmo que com alguns períodos sem ofertar ao público nenhum novo volume da série, os Documentos interessantes mantiveram certa regularidade, nunca ficando mais de 5 anos sem que um novo exemplar da coleção fosse publicado. Contudo, é possível afirmar que, apesar de manter-se como uma publicação regular da instituição, o volume de exemplares foi ficando cada vez mais escasso. Entre os anos de 1947 (volume 71) e 1990 (volume 95) foram editados apenas 24 novos números, com periodicidade pouco regular (o volume $\mathrm{n}^{\circ} 93$ foi publicado no ano de 1980, e após 10 anos de intervalo foram lançados os dois últimos exemplares da série).

Apesar da importância adquirida junto a um segmento do meio acadêmico paulista ${ }^{19}$ é possível perceber como um dos grandes "inconvenientes" da reprodução sistemática de documentos sem a menor preocupação de referenciá-los quanto à sua localização física, mesmo em épocas mais recentes, afirmando de maneira quase inquestionável e infalível o caráter de fé pública existente na instituição. Além disso, cabem aqui algumas questões. Por que a reprodução de determinados documentos e não outros do mesmo período? Teriam sido reproduzidas todas as peças documentais referentes a um tema, ou período, presentes no acervo? Foram levados em conta princípios como a organicidade e proveniência (especialmente para volumes produzidos após os anos 1950)? Quais os critérios de seleção? Após reproduzidos, que princípios técnicos foram adotados visando a conservação dos originais? $?^{20}$ Em nenhum dos casos existem respostas claras, seja por parte da historiografia, seja pela própria instituição. Uma referência direta feita aos documentos originais partiu de um Diretor do Arquivo, Ubirajara Dolacio Mendes que,

\footnotetext{
19 Se inicialmente a seleção, transcrição e disponibilização dos documentos existentes no acervo da Repartição de Estatística e Arquivo contava com a atuação direta dos membros do IHGSP, a formação desses intelectuais ganharia um novo fôlego com o surgimento da Universidade de São Paulo (1934) e seu curso de História. Contudo, os vínculos existentes entre a intelectualidade paulista e o Arquivo não cessaram.

${ }^{20}$ Vale lembrar que as técnicas adotadas para a conservação de documentos em suporte papel deram um verdadeiro salto de qualidade com o desenvolvimento da indústria química, especialmente no tocante às contaminações por agentes biológicos (especialmente insetos). Durante todo o séc. XIX as ações de conservação restringiam-se à confecção de cópias fiéis dos manuscritos deteriorados. Foi na primeira metade do séc. XX que se relatou o uso de produtos químicos em seu tratamento de conservação, mediante a fumigação de documentos.
} 
no volume 73 (“Ofícios do Capitão General D. Luis Antonio de Souza Botelho Mourão: 1765- 1766”), publicado em 1952, afirmava que os originais daquele material corresponderiam a parte do códice 94 do acervo do Arquivo. Apresentando uma relação das aldeias do padroado, afirmava que:

“apesar de a leitura ser feita por funcionários com longos anos de prática paleográfica, o Arquivo mantém os originais à disposição dos historiadores, para quaisquer dúvidas que possam ocasionalmente surgir" 21 .

Vale salientar que a primeira alusão à existência dos originais nos depósitos da então Repartição de Estatística e Arquivo apareceu apenas em 1902, no volume 39 ("Correspondência do Capitão General Antonio Manoel de Mello Castro e Mendonça"). Tratar-se-ia, aparentemente, da transcrição "integral” do códice 115 de seu acervo. A partir daí, inúmeros volumes passaram a trazer referências quanto aos códices originais, como foi o caso dos volumes 55 (códice 82), 56 a 58 (todos oriundos do códice 83), 59 (códice 85), 60 (códice 58), 61 (códice 59), entre outros. Em alguns casos, um mesmo volume seria fruto da transcrição de documentos existentes em mais de um códice, como o caso dos volumes 65 (códices 63 e 127) e 66 (códices 62, 63 e 127), aparentemente selecionados por uma questão temática e/ou cronológica ${ }^{22}$.

Inegavelmente, a publicação dos Documentos interessantes apresentou-se como fruto de uma determinada visão do fazer história, própria de um momento específico e mantido por inércia, atribuindo a um determinado conjunto de documentos um valor muito mais museal do que propriamente o de peça administrativa produzida de maneira contextualizada. Sendo assim, tanto as unidades documentais aí reproduzidas como os próprios volumes da série não

\footnotetext{
${ }^{21}$ AESP. Documentos interessantes. São Paulo, Casa Eclética, 1952, vol. 73, p. 03.

22 Apesar disso, mesmo que tenham sido produzidas Tabelas de Equivalência, estas não puderam ser localizadas, dificultando o trabalho de futuros pesquisadores que, por ventura, queiram cotejar as transcrições com os documentos originais. De acordo com Ana Maria Camargo e Heloísa Bellotto este seria um "instrumento que estabelece relação de concordância com diferentes notações dos mesmos documentos", apontando os novos "endereços" físicos dos documentos mesmo após mudanças e reorganizações do acervo. CAMARGO, A. M. de A., BELlotTO, H. L. (coord.). Dicionário de terminologia arquivística. Op. Cit., p. 72. Para maiores informações quanto aos códices "originais”, ver Anexo I.
} 
poderiam ser vistas superficial e rasteiramente como estruturas imbuídas de neutralidade, sem trazer intrinsecamente à sua composição, interferências propositais, arquitetadas e levadas a cabo de maneira premeditada.

O volume 48 ("Documentos relativos à história da Capitania de São Vicente e do bandeirismo: 1548-1734"), de 1929, pode ser tomado como um exemplo disso. Sendo uma obra cuja organização e preparo apresentava-se concluída desde 1917, deu início a uma seqüência de exemplares em que foram publicados documentos referentes à capitania de São Vicente, levantados, compilados e anotados pelo historiador e folclorista Basílio de Magalhães, sob ordem do governo de São Paulo. De acordo com informações registradas no próprio volume, os documentos originais aí selecionados poderiam ser localizados nos acervos do Instituto Histórico e Geográfico Brasileiro e no Arquivo Nacional, ambos no Rio de Janeiro. Temas como o bandeirismo paulista também foram tratados nessa seleção. Tal iniciativa estendeu-se até o volume 54, lançado em 1932 sob o título "Relação dos documentos históricos existentes no Arquivo Nacional e respeitantes a São Paulo, compreendidas as circunscrições que ao tempo lhe estavam anexas (1534- 1879)"23. Em alguns casos, documentos foram selecionados mesmo já tendo sido publicados pelo próprio Arquivo Nacional, detentor do material, devido a eventuais equívocos de tradução paleográfica apontadas por Magalhães ${ }^{24}$.

A publicação de todo esse material apresenta questões por vezes pitorescas. Esse talvez seja o caso do volume 51 ("Documentos relativos ao bandeirismo paulista e questões conexas") que, em sua apresentação trata de um texto intitulado “A expansão geográfica do Brasil até fins do séc. XVII", que teria sido apresentado no I Congresso de História Nacional (em setembro de 1914), mas que não fora publicado no respectivo exemplar para não retardar seu lançamento. Esse volume

\footnotetext{
${ }^{23}$ Apesar desses volumes terem vindo a público apenas entre os anos de 1929 e 1932 , de acordo com as anotações existentes em suas introduções, tratava-se de material preparado para publicação muito tempo antes. Em alguns casos, desde 1914 ou 1915, como nos volumes 51 e 52 respectivamente. Para maiores informações, ver Anexo I.

${ }^{24}$ AESP. Documentos interessantes. São Paulo, Casa Eclética, 1929, vol. 50, p. 03.
} 
dos Documentos interessantes somente veio a público em 1930, 16 anos depois do respectivo congresso, tempo aparentemente suficiente para uma criteriosa revisão.

Em 1937, após 5 anos sem a publicação de nenhum novo exemplar da série, foi lançado o volume 55 ("Correspondência oficial do Capitão General Antonio José da França Horta"). Tratava-se do início de uma "parceria" entre o Arquivo e o Instituto Histórico e Geográfico de São Paulo. Amparado pela lei no 2.800 (de 28 de dezembro de 1936) o IHGSP tornou-se o responsável por coordenar as publicações do Arquivo (o acordo estabelecia a edição de 12 novos volumes da série, contando cada um com 350 páginas). Por meio dessa intervenção caberia também ao Instituto dar continuidade a outras duas coleções de publicações do Arquivo, sendo elas as séries de Inventários e testamentos e os volumes referentes a Sesmarias. Por uma questão pragmática, optou-se pela publicação de documentos mais recentes, ou em melhor estado de conservação, para que não se perdesse tempo com traduções. Com isso, foram aproveitados diversos materiais já preparados e prontos devido ao empenho do corpo técnico do próprio Arquivo.

Foram publicados, além das correspondências do Capitão General Antonio José da França Horta, ordens régias e avisos militares, um recenseamento dos habitantes da capital ocorrido entre os anos de 1765- 67 e inventários e testamentos setecentistas da cidade de Ubatuba. Este último material foi todo ele compilado em um único volume da série, o de número 66 , referente a documentos recolhidos do Cartório do $1^{\circ}$ Ofício da cidade de Ubatuba devido à esperança de preservação da documentação cartorária mediante a criação do Departamento do Patrimônio Histórico de São Paulo. Logo na introdução do volume, Paulo Duarte apontava para a necessidade de se fazer uma história paulista e do Brasil, até então acanhada devido à falta de fontes documentais. Para ele boa parte da documentação estaria ainda por ser lida, estando ela depositada em acervos nos estados de Minas Gerais, Rio de Janeiro, diversos cartórios (especialmente naqueles que ainda não tinham conseguido destruir tudo, apesar dos esforços), em acervos governamentais portugueses e espanhóis, assim como junto a ordens religiosas como a dos jesuítas. 
No ano seguinte a Repartição talvez tenha atravessado seu período mais difícil. Por decreto governamental os serviços estatísticos haviam sido retirados das atribuições do órgão e direcionados para um novo Departamento Central de Estatística, recém criado $^{25}$. Como a documentação administrativa do Estado não poderia ficar sem tutela, por ação do Sr. Adhemar Pereira de Barros (Interventor Federal) foi assinado um decreto ${ }^{26}$ que renomeava a extinta Repartição, passando a chamar-se Departamento do Arquivo do Estado. Esse novo órgão foi dotado de três seções independentes, responsáveis pelos negócios administrativos, documentação histórica e expediente e contabilidade.

Tratando das atividades desenvolvidas pela Repartição entre os anos de 1930 e 1938, foi encaminhado um relatório assinado por Francisco Azzi ao Sr. Augusto Meirelles Reis Filho, então Secretário da Educação e Saúde Pública, órgão ao qual o Arquivo estava vinculado. Nele o Diretor fazia duras críticas à criação do Departamento de Estatística que, em sua visão, seria um “órgão útil, legal, louvável sob vários aspectos, e até necessário", mas não deveria ter surgido mediante "rude mutilação do mais antigo dos aparelhos estatísticos oficiais"27. O novo Departamento era visto como macrocéfalo, sendo uma "imensa cabeça quase sem corpo",28.

Na mesma ocasião, o Diretor aproveitou para criticar a "parceria" com o IHGSP pois, tudo aquilo que fora publicado mediante o convênio havia sido

\footnotetext{
${ }^{25}$ Trata-se do decreto $\mathrm{n}^{\circ}$ 9.036, de 14 de março de 1938.

${ }^{26}$ Trata-se do decreto $\mathrm{n}^{\circ} 9.285$, de 01 de julho de 1938. Uma vez perdia a função de produção e análise estatística, o novo órgão, responsável pela avaliação, recolhimento, guarda, e disponibilização dos documentos produzidos pelo poder público paulista perdia seu único contato direto com a administração pública. Com isso o Departamento passou a ser visto, paulatinamente, como mero depósito de papéis velhos, sem nenhuma função administrativa direta. Na visão de José Witter, o Arquivo do Estado apresentar-se-ia como uma instituição sui generis por ser ela detentora de inestimável acervo documental, fornecendo o maior volume de subsídios aos estudiosos paulistas, mas não ter reconhecimento algum das estruturas administrativas, ficando relegado a uma estrutura subalterna do governo, e não subsidiária das ações governamentais. Ver: WITTER, José Sebastião. Arquivo e história. O Arquivo do Estado de São Paulo na administração e na história. Tese de Livre Docência apresentada na FFLCH da Universidade de São Paulo, 1981.

${ }^{27}$ AESP. Relatório da Repartição de Estatística e Arquivo (1938). São Paulo, AESP, 1938, pp. 10- 11.

${ }^{28}$ Ibidem.
} 
preparado pela própria Repartição. A divulgação apenas não teria ocorrido devido à falta de recursos orçamentários do Estado.

Diante tantas críticas, mesmo com aquilo que era estabelecido em lei, apenas 9 volumes de Documentos interessantes vieram a público e, em 1939, quando foi rescindido o contrato com o IHGSP, voltaram a ser de responsabilidade do próprio Arquivo suas publicações. Nesse mesmo ano foi publicado o volume 64 intitulado "Ofícios do Capitão General D. Luis Antonio de Souza Botelho Mourão aos diversos funcionários da Capitania (1772- 1775)" que, de acordo com o então Diretor João Lellis Vieira, seria fruto direto da retomada de investimentos por parte do governo paulista em uma de suas "obrigações" históricas, tão necessários para o cumprimento de sua "rota patriótica"29.

Apesar dos esforços de seu corpo técnico, muito do material depositado no acervo do Arquivo perecia devido às más condições de conservação. Um bom exemplo disso é o volume 65 ("Ofícios do Capitão General D. Luis Antonio de Souza Botelho Mourão aos diversos funcionários da Capitania"), compilando o códice 64 do acervo (correspondência de governo entre 1765 e 1771). Apesar de ser um tema que causava certo frisson junto aos historiadores paulistas, por trata-se de período imediatamente posterior à recriação da capitania, extinta em 1748, a opção por tal publicação veio apenas em decorrência do códice 68 , publicado no volume 64 da coleção, ter desaparecido devido à má conservação.

Em 1942, quando da publicação do volume 66, o Arquivo contava com um volume de 909 consulentes por ano ${ }^{30}$. Nesse contexto, a intenção de manter os Documentos interessantes seria para vulgarizar as raridades manuscritas existentes no acervo visto que, naquele momento a instituição já contava com biblioteca especializada, coleção de leis e decretos, jornais, revistas, mapas estatísticos, relatórios e um conjunto razoável de publicações. Todo esse aparato informativo vinha para reforçar a necessidade de investimentos governamentais no sentido de

\footnotetext{
${ }^{29}$ AESP. Documentos interessantes. São Paulo, Casa Eclética, 1939, vol. 64, p. 03.

${ }^{30}$ Dados referentes ao ano de 1941. AESP. Documentos interessantes. São Paulo, Casa Eclética, 1942, vol. 66, p. 03.
} 
dotar a instituição com uma sede própria, capaz de dar vazão às necessidades do público pesquisador ${ }^{31}$.

Devido à falta de sistematização e organização dos originais, assim como a sistemática escassez de recursos, muitos volumes tornaram-se repetitivos quanto ao tema, apesar de percorrerem períodos cronológicos distintos. Esse foi o caso das correspondências mantidas pelo Capitão General D. Luis Antonio de Souza Botelho Mourão (Morgado de Matheus). Iniciada sua publicação no volume 19 (1896), foi retomada nos volumes 33 a 35 (todos de 1901), 64 e 65 (1939 e 1940), 67 a 69 (de 1943 a 1946), 72, 73 (ambos de 1952) e 92 (1978).

Mesmo gozando de grande interesse, esses originais talvez não tenham sido publicados sistematicamente na época em que Antonio de Toledo Piza era o Diretor da Repartição devido ao precário estado de conservação dos originais, sendo comuns as referências a partes dos textos danificadas pela ação da água, possibilitando, em alguns casos, a leitura apenas palavras soltas ${ }^{32}$.

Durante muito tempo a visão que o Arquivo teve de si, e mesmo do papel de São Paulo diante da história nacional, pouco sofreu alteração. Em 1946, logo na abertura do volume 70, João Lellis Vieira colocava o Arquivo como "verdadeiro Instituto do passado", afirmando seu caráter universitário na medida em que constitui a "cátedra máxima da História Paulista e do Brasil"33. Essa mesma visão foi defendida por Célio Debes quase 50 anos depois, ao afirmar que

"a história corrente é manipulada pelos vencedores. E São Paulo, há mais de seis décadas, é o vencido. Os arquivos dos homens que participaram de suas glórias- e que, por isso, justamente, amargaram as agruras da derrota- é que deverão propiciar a restauração dos fatos, permitindo que se possa expungir de nossos fastos a manipulação maliciosa e cínica, que torna tais fastos caricatos" ${ }^{34}$.

\footnotetext{
${ }^{31}$ Nesse volume foi apresentada ao público a imagem do projeto de uma futura sede do Arquivo do Estado, elaborado pela Secretaria da Viação e Obras Públicas. Idem, p. 07.

${ }_{32}^{32}$ AESP. Documentos interessantes. São Paulo, Casa Eclética, 1946, vol. 69, p. 07.

${ }^{33}$ AESP. Documentos interessantes. São Paulo, Casa Eclética, 1946, vol. 70, p. 04.

${ }^{34}$ DEBES, Célio. "A revista do Instituto Histórico e Geográfico de São Paulo e a pesquisa histórica". In: IHGSP. Revista do Instituto Histórico e Geográfico de São Paulo. São Paulo, IHGSP, vol. 88, 1993, p. 65.
} 
Após mais um período de 5 anos sem que nenhum novo exemplar dos Documentos interessantes fosse lançado, veio a público o volume 72. Tratava-se da publicação de originais existentes em parte do códice 94 do acervo do Arquivo, em péssimo estado de conservação devido à existência de rasgos, água e trechos ilegíveis (a leitura de documentos apagados somente pode ser feita mediante o uso de luz ultra-violeta, pois os sais ferrosos presentes na composição da tinta impediam a fluorescência do papel). Como uma nova sede fora inaugurada (esse teria sido o motivo para um período tão longo sem publicações), o texto introdutório apresentou um trecho da fala de Laurindo de Brito (presidente da Província de São Paulo) à Assembléia, transcrito em Relatório de 1881, sobre a necessidade de se dotar o arquivo de meios para tratar os documentos visto que "amontoados os papéis e sujeitos à unidade, muitos deles já se acham inutilizados, documentos esses imprescindíveis para o conhecimento da história da Província”35.

O ano de 1954 mostrou-se profícuo para o Arquivo e suas publicações. Em mais uma nova sede foram lançados outros 6 volumes da série (do 74 ao 79), todos referentes a ofícios do Capitão General Martim Lopes Lobo de Saldanha. A importância do material residiria no fato de os assuntos tratados serem "interessantes aos nossos fastos" ${ }^{\text {36 }}$. Nas palavras de Américo Mendes, a documentação interessaria aos pesquisadores imbuídos da "tarefa de ilustrar o povo, fortalecendo cada vez mais o valor da história, na formação do civismo e do patriotismo de nossa gente" ${ }^{\text {37. }}$.

É curioso notar que, objetivando diminuir custos com a publicação, em dado momento optou-se por suprimir os índices dos respectivos volumes. Isso ocorreu a partir do número 79, estendendo-se até o 83. Em 1961 foi publicado um exemplar dedicado aos "Ofícios do General Martins Lopes de Saldanha (Governador da Capitania): 1782- 1786". Para César Teixeira Penteado tratar-se-ia de "cópia fiel do último dos livros originais, classificado sob o número setenta do códice deste

\footnotetext{
${ }^{35}$ AESP. Documentos interessantes. São Paulo, Casa Eclética, 1952, vol. 72, p. 06.

${ }^{36}$ AESP. Documentos interessantes. São Paulo, Casa Eclética, 1954, vol. 76, p. 03.

${ }^{37}$ AESP. Documentos interessantes. São Paulo, Casa Eclética, 1954, vol. 79, p. 01. Não se pode perder de vista ser esta a época das comemorações do IV Centenário de fundação da cidade de São Paulo, "berço" do movimento bandeirante e do "pioneirismo" nacional.
} 
Órgão" ${ }^{38}$. Vale notar que, devido ao grande volume de informações contidas em todos os exemplares da série, recorrentemente foram publicados volumes índice. Estes são os casos dos volumes 21 (1897), 71 (1947) e 91 (1968). Os quatro últimos exemplares da série nunca foram indexados em nenhum índice ${ }^{39}$.

A questão da falta de índices acometeu outros volumes da série. Este foi o caso do volume 86, dedicado às "Atas do Conselho da Presidência da Província de São Paulo (1824-1829)”. Apesar do título, o exemplar trouxe a público as atas do Conselho Provisório escritas entre os anos de 1824 e 1834 com exceção de 1827, "que não se acha arquivado no Departamento" Conselho em 1835, devido à criação da Assembléia Provincial, documentos com semelhantes características continuaram sendo produzidos, visto que a função burocrático-administrativa permaneceu em vigor. A continuação desta "série" de documentos pode ser encontrada nos volumes 15 e 16 do Boletim do Arquivo ${ }^{41}$.

Com a edição do volume 92, dedicado aos "Ofícios do General D. Luiz aos diversos funcionários da Capitania (1768-1772)", foi publicado um artigo fazendo um apanhado geral dos 84 anos de existência dos Documentos interessantes. Nele, Amélia F. Trevisan aponta que os critérios adotados para a publicação sempre foram os mais variados, indo desde a seleção de papéis avulsos, códices e mesmo coletâneas de documentos. Para a autora os documentos referentes ao Morgado de Matheus só poderiam ser lidos após a compra de aparelhos de luz ultra-vileta (1953), mas tal informação não procede, conforme avaliado anteriormente ${ }^{42}$.

Mesmo com grande lapso temporal, em 1990 foram publicados os dois últimos volumes da série, os de números 94 e 95, ambos referentes aos "Ofícios do

\footnotetext{
${ }^{38}$ AESP. Documentos interessantes. São Paulo, Casa Eclética, 1961, vol. 84, p. 07.

${ }^{39}$ Em relação aos índices, vale aqui uma ressalva. Como muitos dos volumes da série foram sendo reeditados mediante demanda, fosse para atender a consulentes, fosse pela necessidade de material de divulgação (ver Capítulo II), existe certa imprecisão quanto às informações expressas nos índices, especialmente no que diz respeito à paginação (uma equivalência foi registrada apenas quanto ao primeiro volume da série). Para ter acesso à relação de todos os documentos registrados nos 95 volumes dos Documentos interessantes, ver Anexo III.

${ }^{40}$ AESP. Documentos interessantes. São Paulo, Casa Eclética, 1961, vol. 86, p. 05.

${ }^{41}$ Apenas para deixar registrado, os volumes 87 a 90, 94 e 95 também não possuem índices.

42 O primeiro volume a fazer alusão à administração de D. Luiz Antonio de Souza veio a público em 1896 (volume 19 dos Documentos interessantes).
} 
General Horta aos Vice-Reis e Ministros". Um elemento importante desses exemplares, mas que apareceu pela primeira vez no volume 93, foi a apresentação de um índice específico das abreviaturas utilizadas. A experiência mostrou-se tão produtiva que levou o Arquivo a publicar, em parceria com a Universidade do Estado de São Paulo (Unesp), uma obra que se tornaria referência na área de transcrição documental. Trata-se do livro de Maria Helena Flexor ${ }^{43}$, uma das ferramentas indispensáveis para a leitura de documentos originais ou transcritos, visto ser o uso de abreviaturas uma prática administrativa recorrente tanto no Brasil como em Portugal, fosse visando a economia de material, fosse objetivando a diminuição do tempo gasto na elaboração de documentos manuscritos.

No primeiro capítulo desse trabalho tem-se a intenção de discutir o panorama sócio-cultural e político de São Paulo na virada do séc. XIX para o XX, contextualizando a criação efetiva do Arquivo do Estado junto a uma política governamental muito mais ampla no tocante à consolidação de determinados grupos políticos no cenário regional e nacional. Para tanto, pretende-se demonstrar como foram estabelecidos mecanismos de construção identitária a partir de políticas públicas capazes de consolidar uma imagem pioneira de São Paulo no tocante ao desenvolvimento econômico e cultural nacional. Além disso, será demonstrado os vínculos institucionais existentes entre o Arquivo do Estado e o Instituto Histórico e Geográfico de São Paulo (IHGSP), cabendo ao primeiro a disponibilização de documentos fidedignos e autênticos, e ao segundo a produção de trabalhos analíticos acerca da história paulista.

O processo de modernização conservadora e periférica pelo qual passou São Paulo, com o crescimento urbano da metrópole, ocasionado pelo café, o surgimento de novos bairros e atividades econômicas, a implantação de políticas de incentivo à imigração européia, a influência cultural exercida por esses "novos" agentes e o controle estatal sobre esses indivíduos, foram tratados na primeira parte do capítulo.

\footnotetext{
${ }^{43}$ FLEXOR, Maria Helena Ochi. Abreviaturas: manuscritos dos séculos XVI ao XIX. São Paulo, AESP/ Editora da Unesp, 1991.
} 
A adoção de reformas no campo sócio-educacional levaram o governo paulista a instalar na capital novos estabelecimentos de ensino, voltados à formação de um público laico e republicano. Assim, surgiram a Escola Normal da Praça, a Escola Politécnica e o próprio Museu Paulista que, ao longo das duas primeiras décadas do séc. XX foi consolidando sua vocação histórica nacionalista, tendo São Paulo como seu berço.

No mesmo cenário, surgia a Repartição de Estatística e Arquivo, alvo da segunda parte do capítulo. Se por um lado, mostrava-se necessário a institucionalização de um órgão capaz de subsidiar as ações administrativas do Estado com seus cálculos estatísticos e efetivo controle administrativo, por outro, objetivava-se dar racionalidade e visibilidade aos documentos históricos produzidos e acumulados pela administração no correr do tempo, dando-lhes guarda, organização, conservação e acesso por meio de instrumentos de pesquisa eficientes. Vale lembrar que muitos dos quadros estatísticos produzidos pela Repartição foram utilizados como mecanismos de propaganda de São Paulo no exterior, mostrando o progresso e modernidade paulista diante do restante do país. Sob o comando de Antonio de Toledo Piza as duas funções foram levadas a cabo, sendo deste momento o início da publicação dos Documentos interessantes e da "parceria" entre a Repartição e o IHGSP. Aliás, este vínculo é retratado, bem como o debate historiográfico acerca da figura do bandeirante, na terceira e última parte do capítulo.

Se um novo Brasil estava surgindo, nada melhor que colocar São Paulo em um lugar de destaque nesse processo. Historiograficamente, a figura do bandeirante nem sempre foi bem vista pelos historiadores, especialmente aqueles radicados no Instituto Histórico e Geográfico Brasileiro (IHGB). Uma vez que São Paulo passou a gozar da existência de seu próprio instituto, essa característica foi sendo alterada, ficando a cargo do IHGSP a constituição de um discurso identitário próprio, legitimando a hegemonia paulista sobre o restante do país. Para tanto, era necessário que documentos fossem localizados, tratados e disponibilizados. Daí os fortes 
vínculos que uniram a Repartição ao Instituto desde sua criação, visto que seu lema era: "a história de São Paulo é a própria história do Brasil".

Na seqüência, a primeira parte do segundo capítulo visa discutir propriamente a linha editorial adotada pela Repartição de Estatística e Arquivo ao longo das primeiras décadas do séc. XX, especialmente publicando reproduções documentais sob diversas rubricas, fossem elas Inventários e testamentos, Sesmarias, Boletim do Departamento do Arquivo, Documentos avulsos, ou os Documentos interessantes para a história e costumes de São Paulo.

Esta última, iniciada em 1894, por iniciativa de Toledo Piza, estendeu-se até a década de 1990. Durante boa parte de sua existência, contou com a participação direta de vários dos membros do IHGSP como Orville Derby, Teodoro Sampaio e Domingos Jaguaribe, além do próprio Toledo Piza que, juntamente com a função de Diretor da Repartição foi também um dos fundadores do Instituto paulista e membro responsável pela edição de sua Revista. Vale lembrar que foram nas páginas dessa publicação que muitos dos estudos promovidos por essa intelectualidade foram divulgados embasando-se, na maioria das vezes, em documentação levantada e publicada pelo Arquivo. É importante lembrar que, diferente do que se pensou durante muito tempo, alguns dos 95 volumes trazem ensaios e artigos analíticos sobre temas relacionados a questões sócio-políticas e econômicas de São Paulo, e não necessariamente reprodução de documentos.

Uma análise mais atenta a respeito desses agentes e dos próprios Documentos interessantes, pelo menos em seu primeiro momento, foi realizada na segunda parte desse capítulo, visando demonstrar os vínculos institucionais e ideológicos existentes entre a Repartição e a elite intelectual paulista. Como visto anteriormente, dos 95 volumes constantes na publicação, 43 deles foram publicados até 1903, tendo Toledo Piza à frente da empreitada. Temas como a administração colonial em São Paulo, a independência do Brasil e o estabelecimento das divisas do estado mostraram-se recorrentes nesses volumes, tentando demonstrar a grandiosidade paulista juntamente com a de seus bravos bandeirantes. 
Foi aí que algumas observações acerca da importância da adoção de política de reprodução documental, bem como sua divulgação, foram levadas a cabo.

As questões relacionadas aos dilemas estabelecidos pela (re)construção da memória coletiva e institucional, assim como o debate sobre o papel exercido pelos arquivos como espaço de preservação de um determinado tipo de patrimônio cultural público, constam do terceiro capítulo. Vale salientar que a importância desse debate amarra-se no fato de ser essa memória o espaço próprio de construção identitária de determinados grupos sociais, agindo tanto como ferramenta de poder e dominação, como instrumento de manifestação residual, mesmo que por vezes, "inventada". Este seria o caso da própria imagem do bandeirante paulista, estabelecida por meio de uma memória amparada em vestígios de um passado preservados e divulgados de maneira deliberada, responsável por estabelecer o que deveria ser lembrado ou esquecido.

Os elementos apresentados na primeira parte desse capítulo dialogam diretamente com as questões estabelecidas ainda no Capítulo I, na medida em que a modernidade paulista da virada do séc. XIX para o séc. XX precisava encontrar respaldo em uma memória oficial, capaz de equalizar as diferentes referências individuais em nome de uma memória coletiva, aglutinadora dos diversos agentes sociais envolvidos na constituição da metrópole, relegando a um segundo plano tudo aquilo que implicasse identificação com grupos oprimidos ou minoritários.

Levando-se em conta o poder de influência da escola metódica no Brasil, o uso do documento escrito na pesquisa historiográfica no séc. XIX e boa parte do séc. XX, mostrava-se imprescindível. Contudo, ele deixaria de ser visto apenas como resíduo de uma manifestação ocorrida no passado, sendo encarado como seu produto direto, preservado e disponibilizado intencionalmente, alimentando uma determinada memória.

A patrimonialização do material arquivístico também se mostrou tema relevante desse capítulo, especialmente devido ao seu vínculo ideológico com a constituição de uma identidade supostamente monolítica para São Paulo, produzindo 
valores que, apesar de comungados na coletividade, representariam os interesses de grupos sociais específicos. O esforço em apagar as identidades "estrangeiras", fossem elas oriundas de outros países ou mesmo outras regiões do país, em nome de um ambiente agregador, servia especialmente a determinados grupos da elite, docilizando realidades mais amplas e complexas.

Foi por meio da constituição de instituições arquivísticas que determinados conjuntos documentais passaram a ser preservados e disponibilizados, tornando-se, por vezes, verdadeiros espaços de fossilização do passado. Vistos originalmente como arsenais administrativos, passaram a servir a um papel de reconstituição histórica importante.

Além disso, os temas relacionados à teoria arquivística, em especial a gestão documental e o estabelecimento de políticas públicas de descarte, serão tratados aí. Vale lembrar que estes são elementos fundamentais na constituição seja da memória, seja de representações sobre o passado como forma de manifestações de poder. Para tanto, foi levada em conta a teoria das representações, de Henri Lefebvre, que coloca a reconstrução do passado como espaço de possibilidades, servindo para a constituição da própria tessitura social. Sua (re)construção está amparada em uma determinada valoração, própria de sua relação tempo-espaço.

O presente trabalho conta ainda com três anexos. O primeiro, dedicado aos próprios Documentos interessantes, apresenta uma relação de cada um dos 95 títulos da série, contendo ano de publicação, periodização dos documentos que o integram e eventuais observações realizadas a partir da leitura de cada um dos volumes. Devido à falta de outro instrumento de pesquisa mais adequado, um segundo anexo foi elaborado contendo os títulos de cada um dos 16 volumes do Boletim do Departamento do Arquivo e seus respectivos anos de publicação. O terceiro anexo, encartado na contracapa do volume, diz respeito a uma base de dados elaborada em MS Access contendo os registros de todos os documentos publicados ao longo dos 95 volumes da série Documentos interessantes. Nele foram descritos o conteúdo genérico de cada um dos documentos, sua tipologia, data (quando existente), bem 
como sua localização (referências quanto ao volume e paginação). Os dados aí contidos foram retirados dos próprios volumes índice, com exceção daqueles em que as referências não foram incorporadas. Nesses casos, optou-se pela elaboração dos índices mediante a leitura dos próprios volumes. É importante salientar que para a alimentação de parcela significativa dos cerca de 22 mil registros, o trabalho contou com o auxílio da historiadora Ana Lúcia Rodrigues da Luz.

A intenção do presente trabalho é contribuir, mesmo que de maneira rudimentar, para o debate acerca do papel desempenhado pelo Arquivo Público de São Paulo na edificação da uma identidade paulista, bem como o efetivo que os arquivos públicos devem ocupar no cenário político brasileiro quanto à preservação documental, subsidiando uma constante (re)construção de representações sobre o passado. Vale salientar que não se tratam de meros espaços dotados de neutralidade, mas sim, locais híbridos que permitem tanto novas elaborações historiográficas, como o estabelecimento de debates acerca de políticas públicas concernentes à conservação de um determinado repertório burocrático, capaz de subsidiar o Estado em sua tarefa administrativa. 


\section{Capítulo 1}

\section{O desenvolvimento urbano de São Paulo e a construção de sua identidade}

\section{1- Aspectos gerais de São Paulo}

Para uma melhor compreensão da abrangência e importância das ações governamentais adotadas no final do séc. XIX no sentido de se construir uma identidade nitidamente paulista, utilizando-se para tanto de instituições recém criadas como o próprio Arquivo do Estado, mostra-se de fundamental importância perceber qual a situação de São Paulo em termos populacionais, físicos e intelectuais no decorrer do século. Se por um lado, o volume de estrangeiros e migrantes tornava-se cada vez maior na medida em que a capital se efetivava como um importante centro econômico, por outro, os agentes públicos precisavam tomar certas atitudes para garantir o "distanciamento" desses mesmos setores sociais em relação às elites, fosse por mecanismos acadêmicos (historiográficos), sociais ou geográficos, que atuavam como ferramentas efetivas de um processo de inclusão em um novo sistema econômico capitalista por meio de controle sociais, delimitando-se os espaços de circulação e atuação desses novos agentes ${ }^{44}$.

É sabido que a segunda metade do séc. XIX foi marcada pelo grande crescimento de São Paulo, tanto em termos populacionais quanto urbanísticos. A expansão do poder do Estado amparava-se na proliferação de cafezais pelo interior visando atender a uma crescente demanda internacional. Para Hernani Donato, a abertura de novas áreas pioneiras no oeste paulista fazia

\footnotetext{
${ }^{44}$ De acordo com as idéias dos economistas Paul Baran e Paul Sweezy, a lógica do capitalismo monopolista amparava-se na criação, muitas vezes arbitrária, de excedentes e a adoção de mecanismos de pressão para que os mesmos fossem absorvidos e assim retroalimentassem o sistema produtivo. Nesse sentido, a incorporação de novos sujeitos, associados aos já existentes, permitiria agilizar e ampliar tal processo, mesmo que aparentemente, parcela significativa desse contingente permanecesse marginalizada. Para maiores esclarecimentos vale a leitura de: BARAN, P.; SWEEZY, P. Capitalismo monopolista. Rio de Janeiro, Zahar, 1966.
} 
"brotar fazendas, vilas, oficinas, depósitos, fortunas, muitas e grandes fortunas; nas ferrovias estendidas com fúria em diversas direções, especialmente a São Paulo Railway; no porto de Santos, desde 1893 o primeiro do mundo na exportação de café; nas dezenas de fábricas que respondiam à demanda de bens e de serviços decorrentes do crescimento populacional",45.

Vale lembrar que a implantação de uma grande malha ferroviária pelo mundo foi possível graças às elevadas somas de capitais ingleses disponíveis no decorrer do séc. XIX, tornando-se o setor preferido dos investimentos capitalistas por mais de meio século. Assim, coube às estradas-de-ferro responsabilizarem-se por produzir significativas mudanças na geografia econômica, influenciando nos processos migratórios e na formação de novas comunidades. É importante perceber que esta se tornou uma das principais ferramentas utilizadas pelo sistema para a ampliação de mercados a produtos industriais, além de permitir a entrada de um volume de capitais para investimento ainda maior que aqueles mobilizados no setor de transporte ${ }^{46}$.

Foi nesse mesmo contexto que São Paulo passou a receber um grande volume de europeus, imprimindo à cidade um ritmo cada vez mais acelerado, com uma profusão de idiomas e culturas de diferentes pontos do mundo. De acordo com dados apresentados por Lucia Lippi Oliveira, entre os anos de 1870 e 1930 entraram na América entre 31 e 40 milhões de imigrantes ${ }^{47}$.

As motivações que levaram esses imigrantes a abandonarem suas terras de origem e se deslocarem para o Brasil podem ser entendidas sob diferentes perspectivas, com especial atenção às perseguições de cunho religioso, as dificuldades econômicas e as questões políticas locais, além das motivações pessoais. Para a historiadora Silvia Cristina Lambert Siriani ${ }^{48}$, os imigrantes de

\footnotetext{
${ }^{45}$ DONATO, Hernani. “A cidade de São Paulo em 1894”. In: Revista do Instituto Histórico e Geográfico de São Paulo. São Paulo, vol. 88, 1993, p. 09.

${ }^{46}$ BARAN, P; SWEEZY, P. Capitalismo monopolista. Op. Cit.

${ }^{47}$ OLIVEIRA, Lucia Lippi. O Brasil dos imigrantes. Rio de Janeiro, Jorge Zahar Editora, 2001.

${ }^{48}$ SIRIANI, Silvia Cristina Lambert. Uma São Paulo alemã: vida quotidiana dos imigrantes germânicos na região da capital (1827- 1889). São Paulo, Arquivo do Estado/ Imesp, 2003.
} 
origem germânica em São Paulo, um dos principais elementos que fomentaram o deslocamento de europeus para o Brasil, em especial os alemães, teria sido o processo de desenvolvimento do capitalismo e a industrialização que "atingiu principalmente os artesãos e pequenos proprietários do campo que, falidos, desempregados e espoliados de suas terras, fosse pela grande propriedade agrícola, fosse pelas tradicionais regras de sucessão baseadas na primogenitura" ${ }^{\text {"49 }}$, obrigandoos a optar por novas formas de sobrevivência e reprodução material.

Muitos desses grupos imigrantes acabaram formando núcleos endogâmicos sólidos e duradouros a partir da união promovida pelas dificuldades de adaptação e sobrevivência, como as questões de idiomas ou religiosas.

Para Maria Thereza Petrone, esse fluxo de imigrantes ampliou-se desde a chegada da Família Real portuguesa em terras de além mar em 1808 e a assinatura em 25 de novembro, pelo então Príncipe Regente D. João VI, de um decreto que permitia a propriedade fundiária a estrangeiros. A intenção seria povoar o território e branquear a raça, ou como era comumente defendido pelo jornalista Hipólito José da Costa, "melhorar a população". A implantação de uma forte política imigrantista, contando com a participação direta ou indireta do Estado brasileiro, intensificou-se no decorrer de todo o séc. XIX como forma de "impedir" levantes negros em território nacional, a exemplo do que ocorrera no Haiti no final do séc. XVIII. Tal medida aliviaria as tensões oriundas do elevado número de escravos mantidos no Brasil. Ainda de acordo com Petrone, nas primeiras décadas do séc. XIX a população brasileira atingia a cifra de 3,5 milhões de indivíduos, ao passo que os escravos alcançavam a casa dos 1,5 milhões, dobrando até a extinção do tráfego em $1850^{50}$.

A adoção de uma política de imigração subvencionada tornava o Brasil uma região mais atrativa aos olhares europeus visto que, comumente, era mais barato ir da Europa para os Estados Unidos do que vir para cá, o que acabava por definir o

\footnotetext{
${ }^{49}$ Idem, p. 39.

${ }^{50}$ PETRONE, Maria Thereza Schorer. O imigrante e a pequena propriedade. São Paulo, Brasiliense, 1982.
} 
destino de muitos imigrantes. Assim, em 1886, foi criada a Sociedade Promotora da Imigração, por iniciativa dos cafeicultores de São Paulo e administrada por "alguns dos mais eminentes membros da elite paulista" como os Condes de Itu e Três Rios, o Visconde do Pinhal, os Barões de Tatuí e Piracicaba e o Sr. Martinho da Silva Prado. Cientes do final da escravidão, "buscavam a lucratividade da mão-de-obra supostamente especializada do europeu"51. Buscando a fixação dessa massa imigrante, núcleos coloniais eram abertos pelo interior, com a venda de lotes para imigrantes. Como a intenção não era retirar mão-de-obra já fixada nas fazendas, os lotes de terra eram vendidos a imigrantes recém chegados mediante pagamento de $10 \%$ de seu valor como entrada, e o restante com prazos que variavam de 5 a 10 anos, enquanto para os europeus já fixados, o montante a ser desembolsado à vista era de até $2 / 3$ do valor do lote ${ }^{52}$.

De acordo com Richard Morse, a elevação no volume de entrada de imigrantes em São Paulo entre os anos de 1885 e 1891 coincidiu com o aumento significativo de alforrias concedidas, conforme quadro abaixo ${ }^{53}$.

\section{Entrada de Imigrantes Europeus na Província de São Paulo ${ }^{54}$}

\begin{tabular}{|c|c|}
\hline Ano de entrada & Total de imigrantes \\
\hline 1885 & 6.500 \\
\hline 1886 & 9.536 \\
\hline 1887 & 32.112 \\
\hline 1888 & 92.086 \\
\hline 1889 & 27.893 \\
\hline 1890 & 28.291 \\
\hline 1891 & 108.736 \\
\hline
\end{tabular}

O grande número desses indivíduos, bem como a influência cultural exercida por estrangeiros em São Paulo, atingiu patamares tão elevados que em

\footnotetext{
${ }^{51}$ SIRIANI, S. C. L. Uma São Paulo alemã. Op. Cit, p. 55.

${ }_{53}^{52}$ HOLLOWAY, Thomas H. Imigrantes para o café. Rio de Janeiro, Paz e Terra, 1984.

${ }^{53}$ Vale salientar que a questão da imigração mostrou-se controversa até mesmo entre os membros da elite paulista. Para Eduardo Prado o imigrante, apesar de forte, audaz e enérgico, também não seria um elementos confiável, por ter abandonado sua própria terra. Cf. OLIVEIRA, L. L. O Brasil dos imigrantes. Op. Cit., p.17. ${ }^{54}$ Departamento Estadual de Trabalho. Dados para a história da imigração e colonização em São Paulo. São Paulo, 1916, pp. 11- 13. In: SIRIANI, S. C. L. Uma São Paulo alemã. Op. Cit., p. 55.
} 
1914 o então prefeito da capital, Washington Luis Pereira de Sousa, pôs em vigor uma legislação específica sobre a prática da publicidade nas ruas da cidade. A nova lei estabelecia que todas as mensagens publicitárias espalhadas pelas ruas (pintadas em tabuletas, letreiros ou mesmo folhetos de distribuição direta) deveriam vir acompanhadas por textos traduzidos para o português, sendo ele escrito de maneira visível e em caracteres maiores que os das palavras escritas em língua estrangeira. A penalidade prevista pelo descumprimento da lei seria, além da cobrança obrigatória do imposto publicitário, o pagamento de uma taxa extra de $100 \$ 000$ anuais ${ }^{55}$.

Para se ter uma imagem um pouco mais precisa dessa questão vale a pena lembrar que dos 130.775 habitantes da cidade de São Paulo em 1894, 54,5\% eram de origem estrangeira ${ }^{56}$.

Juntamente com a toda essa presença européia cresceu o processo de urbanização em alguns centros, atrelado à diversificação de investimentos financeiros, fruto dos ganhos aferidos com a cafeicultura. Eventos como o desenvolvimento ferroviário e a instalação de plantas industriais em São Paulo levaram a um rápido adensamento populacional. Como subproduto, nesses centros urbanos crescia também o risco de surtos de epidemias, acarretando no desenvolvimento de políticas de saúde pública associadas às noções de desenvolvimento e processo civilizatório. A partir de 1892 tornou-se obrigação do poder público investir no estudo de doenças, culminando com a criação do Instituto Vacinogênico e nos hospitais de isolamento esparramados por todo o estado ${ }^{57}$. Para a elite ilustrada, os princípios científicos mostravam um triste futuro para a cidade, fosse devido à mistura racial proveniente da mestiçagem de brancos, negros e

\footnotetext{
55 BARBUY, Heloísa. A cidade-exposição. Comércio e cosmopolitismo em São Paulo, 1860- 1914. São Paulo, 2006, p. 134.

${ }^{56}$ A Constituição de 1891 estabelecia a nacionalização de todo o estrangeiro residente no país, desde que em 6 meses não se manifestasse de maneira contrária.

${ }^{57}$ CARONE, Edgard. A evolução industrial de São Paulo (1889-1930). São Paulo, Editora SENAC, 2001.
} 
mulatos, fosse pelo elevado índice de relações promíscuas, degenerância, sujeira, vagabundagem, provenientes do perigoso direito de ir e $\operatorname{vir}^{58}$.

O processo de transformação urbana pelo qual passou São Paulo, especialmente a partir de 1850, contou com a participação de inúmeros imigrantes com formação especializada (pedreiros, ferreiros, carpinteiros...), entre eles alemães, espanhóis, italianos e portugueses, além de negros (escravos ou libertos).

Na opinião de Candido Malta Campos, todo processo de modernização periférica semelhante ao que atravessou São Paulo, esbarra em um dilema, qual seja, o de não poder ser levada a cabo na plenitude sem que fossem "questionadas as próprias bases de sustentação do grupo modernizante" ${ }^{49}$. Apesar de profundamente vinculada ao cenário econômico internacional, uma estrutura econômica fundiária como a brasileira apresentava-se como um limitador à modernização, independentemente do volume de novas influências culturais ${ }^{60}$.

Inegavelmente a presença de indivíduos das mais variadas origens fez de São Paulo um foco de diversidade. A efervescência da cidade pautava-se em parte pela adoção de um modo de vida estrangeiro que precisava de produtos importados para realizar-se. Novos hábitos europeus diversificaram a cidade, com destaque para setores como o lazer e sociabilidade, além da "modernização" arquitetônica das residências, numa clara evidência do que Gilberto Freyre chamou de "sociedade transeuropéia". Cafés e confeitarias ganharam o espaço urbano, e as formas de consumo também foram sendo paulatinamente importadas graças à ação de casas

\footnotetext{
58 Tal política culminaria com a criação da escola de Medicina em 1912. Visto que a elite atribuía grande "valor à aparência corporal, à pele limpa, branca, lisa e sem manchas" (p. 56), apenas a prática médica seria capaz de garantir a cura e a manutenção da saúde. Vale lembrar que São Paulo tornou-se a precursora de uma política eugênica, propondo o branqueamento da raça mediante vinda de imigrantes brancos europeus capazes de purificar o sangue "nativo" em até cinco gerações. Sobre o tema vale a leitura do livro de ROMERO, Mariza. Medicalização da saúde e exclusão social. Bauru, EDUSC, 2002.

59 CAMPOS, Candido Malta. Os rumos da cidade. Urbanismo e modernização em São Paulo. São Paulo, SENAC, 2002, p. 22.

${ }^{60}$ É importante salientar que tal situação não reflete um impasse para o processo de modernidade, mas sim à modernização, visto que é pela manutenção de setores atrasados que se pode extrair maior volume de maisvalia.
} 
comerciais instaladas na capital da província ${ }^{61}$. Em seus folhetos de divulgação eram comuns os dizeres "importação direta", em uma demonstração de cosmopolitismo. Além disso, muitos deles eram escritos em quatro idiomas diferentes, visando atender um público cada vez mais amplo. Para Hernani Donato,

"vivia-se melhor. O refinamento, a europeização dos costumes incentivava as récitas de ópera sempre como celebridades européias, as turnês de companhias teatrais estrangeiras, aulas- dezenas delas- de artes, música, de pintura, de escultura, de estucagem, de lavores em mármore" ${ }^{" 62}$.

Vale salientar que, como defende Siriani, juntamente com o elevado fluxo de importações cresceu também o volume de produtos fabricados internamente, como foi o caso de chapéus, relógios, cerveja, tecidos e fundições. Um levantamento feito por Richard Morse indica que dos 94 estabelecimentos industriais existentes em São Paulo em 1901 apenas quatro tinham data de fundação anterior a 1870. Em boa medida, todo esse grande volume de remodelações sempre ocorreu de maneira parcial e em espaços de maior referência simbólica ou importância econômica. Para Malta Campos essas mudanças ocorreriam como forma de garantir uma melhor reprodução do capital, associadas a um efetivo controle social. Assim, se Guilherme Gaensly e Militão de Azevedo foram vistos como o responsáveis por registrar as transformações urbanísticas e arquitetônicas de São Paulo, deixaram de lado uma outra parte da mesma cidade que "crescia em ritmo bem mais intenso do que as obras de Antonio Prado" $"$.

Se por um lado a década de 1870 foi profundamente marcada pelo crescimento urbano da capital da província e seu adensamento populacional, por outro vivenciou uma diversificação de investimentos financeiros. Silvia Siriani aponta que, apesar de prática pouco consolidada no país, alguns imigrantes alemães

\footnotetext{
${ }^{61}$ De acordo com Heloisa Barbuy, em A cidade-exposição, o crescimento comercial de São Paulo pode ser sentido mediante a instalação de sucursais de estabelecimentos comerciais oriundos de Santos e Rio de Janeiro, a elevação dos aluguéis na região comercial, além da abertura de diversas agências bancárias.

${ }^{62}$ DONATO, Hernani. "A cidade de São Paulo em 1894". Op. Cit., p. 12.

${ }^{63}$ CAMPOS, Candido Malta. Os rumos da cidade. Op. Cit., p. 91.
} 
arriscaram investimentos financeiros em mercados de ações como estradas-de-ferro (Sorocabana, Ituana, Mogiana, São Paulo Railway) e de aparelhagem urbana (Companhia Carris de Bonde de São Paulo e Companhia Cantareira de Águas e Esgotos), dando a dimensão do crescimento da cidade ${ }^{64}$.

$\mathrm{Na}$ arquitetura dos novos palacetes houve a implantação de um estilo neoclássico, tão comum ao cenário europeu e estadunidense, associado ao consumo cada vez mais forte de produtos como instrumentos musicais e a famosas cadeiras em madeira torneada em estilo austríaco ${ }^{65}$, em uma clara apropriação de um "novo" estilo de vida. Uma parcela significativa de cidades passou por processos de modernização, sendo dotadas de infra-estrutura, comodidades e mecanismos de controle social semelhantes às oferecidas pelas capitais européias.

Novos bairros eram abertos para atender a uma demanda da elite. Esse foi o caso de Higienópolis e Campos Elísios (criados entre 1880-90), loteados por ação de indivíduos como Victor Nothmann, Frederico Glette e Martin Burchard. Se por um lado a abertura desses empreendimentos mostrou-se como um dos responsáveis pelo processo de especulação imobiliária por que passou a capital paulista, visando atender a um novo estilo de vida da elite tradicional, por outro esse mesmo espírito esteve presente na periferia da cidade, servindo de exemplo desse processo de modernização "controladora". Para Siriani,

"as alamedas ladeadas por árvores, as casas recuadas do alinhamento da rua e dos limites laterais, entre outros fatores, tornaram-se forte atrativo para que os proprietários de chácaras na região passassem a loteá-las, dando início a uma

\footnotetext{
${ }^{64}$ No ano de 1900, todo esse crescimento em serviços públicos culminou com a entrada, em São Paulo, da empresa canadense Light and Power, possuidora de contrato de prestação de serviços de 40 anos com a prefeitura da capital. Com ela os bondes passaram a ser eletrificados, oferecendo maior conforto, segurança, rapidez, além de transportar um maior número de passageiros. CARONE, E. A evolução industrial de São Paulo... Op. Cit. Debate semelhante pode ser encontrado também em SIRIANI, S. C. L. Uma São Paulo alemã... Op. Cit

${ }^{65}$ É importante lembrar que um dos fabricantes europeus que mais se destacaram nessa área foi o prussiano Michael Thonet (1796- 1871), capaz de associar a criatividade à produção seriada, tão importante no transcorrer da primeira revolução industrial, fundindo a prática artesanal com a produção industrial. Suas cadeiras ganharam fama e reconhecimento em meados do séc. XIX, quando sua fábrica já estava instalada em Viena. Para maiores informações vale a leitura de: PALUMBO, Maria Rita. "Bom gosto e bom senso na produção em série: a Casa Thonet". In: DE MASI, Domenico (org.). A emoção e a regra. Os grupos criativos na Europa de 1850 a 1950. Rio de Janeiro, José Olympio, 1999.
} 
onda de especulação imobiliária que só viu paralelo com o que ocorria, na mesma época, com as chácaras na freguesia do Brás, que desapareciam em lotes de terrenos que dariam lugar a empreendimentos menos glamurosos que seus congêneres da zona oeste, visto tratar-se de loteamento para a construção de galpões industriais, vilas e cortiços, onde a grande massa operária, formada especialmente por imigrantes da Itália meridional, ir-se-ia instalar devido à proximidade da fábrica" ${ }^{, 66}$.

Nesse espaço, mostrava-se cada vez mais necessária a constituição de uma estrutura de Estado capaz de controlar todos esses agentes alienígenas não apenas pelo uso da força repressiva, mas também em termos ideológicos e históricos. $\mathrm{Na}$ região das várzeas, um verdadeiro cinturão de fábricas foi sendo instalado, representando sua ocupação. Assim, boa parte das medidas de intervenção urbanística nessas regiões objetivava encobrir, ou até mesmo isolar, a paisagem ocupada por plantas industriais e bairros operários. Na visão de Baran e Sweezy, uma reorientação urbana pautada nos moldes estabelecidos pelo capital não implicaria em uma renovação de fato. Muitas vezes a eliminação de cortiços e moradas populares de uma determinada área, não implica na superação ou eliminação da pobreza, mas sim em sua redistribuição e transferência, tendo em vista a reapropriação da região por parte do capital ${ }^{67}$.

A abertura de novos bairros exigia, por parte da administração pública, novas posturas municipais quanto ao arruamento, higiene, construções, visando atender exigências por infra-estrutura. Objetivando dar vazão a essas necessidades, em 1892 foi criada a Intendência de Obras, numa clara demonstração da ação do poder público sobre a cidade. Ao estudar o processo de reurbanização da região central da capital paulista, Heloísa Barbuy apontou para o fato de, apesar do Código de Posturas $(1875)^{68}$ ter sido fortemente regulador em relação aos projetos arquitetônicos de futuras construções e reformas, os próprios comerciantes foram os

\footnotetext{
${ }^{66}$ SIRIANI, S. C. L. Uma São Paulo alemã. Op. Cit., p. 180.

${ }^{67}$ BARAN, P. SWEEZY, P. Capitalismo monopolista. Op. Cit.

${ }^{68}$ Sobre o tema vale a leitura de: DIAS, Maria Odila Leite da. Quotidiano e sobrevivência em São Paulo no séc. XIX. São Paulo, Brasiliense, 1995.
} 
grandes responsáveis por retardar a "demolição generalizada dos antigos edifícios de taipa, protelando, assim, por mais de um quarto de século o início do 'bota-abaixo' paulistano proposto pelo poder público municipal" ${ }^{\prime 69}$. Na prática, a demolição quase total dos edifícios coloniais da região formada pelas ruas 15 de Novembro, Direita e São Bento ocorreu apenas entre os anos de 1902 e 1912.

Contudo, entre os anos de 1860 e 1914 a cidade passou por um profundo processo de transformação, fosse em seus projetos arquitetônicos e urbanísticos, fosse na exibição de produtos comerciais em vitrines, adotando-se uma estética cosmopolita. Foram postas em prática medidas de modernização de imóveis comerciais no centro de São Paulo, contando com reformas nas fachadas e implantação de vitrines, assim como a reformulação dos espaços internos visava atender tanto a legislação em vigor, como a princípios higienistas. Em todo esse processo foram levados em conta questões como iluminação, aeração e circulação de pessoas e mercadorias.

A virada do séc. XIX para o XX foi marcada pelo processo de verticalização da cidade. No final do séc. XIX São Paulo contava com apenas um prédio de 3 andares, ocupado pela Casa Paiva, esquina da r. 15 de Novembro com a r. do Tesouro ${ }^{70}$.

A adoção de uma série de obras públicas visando a implantação de benfeitorias na cidade acarretou tanto na elevação dos preços dos imóveis como no aproveitamento assustador dos espaços habitáveis. De acordo com Hernani Donato, os $2.800 \mathrm{~m}$ da av. Paulista (aberta em 1891) eram reflexos da "vontade paulista de crescer e inovar", levando a ocupação da cidade para as proximidades do rio Pinheiros, e obrigando a abertura de novos bairros (como a vila América, atual Jardins, construída nos moldes da Companhia City) ${ }^{71}$.

Inegavelmente, a implantação de um processo de urbanização planejada ganhou espaço no mesmo momento em que a cidade passava por um surto de

\footnotetext{
${ }^{69}$ BARBUY, H. A cidade-exposição. Op. Cit., p. 26.

${ }^{70}$ Idem, p. 60.

${ }^{71}$ DONATO, H. “A cidade de São Paulo em 1894”. Op. Cit.
} 
prosperidade econômica associada ao desenvolvimento industrial, trazendo a reboque todo o cientificismo europeu. Para Helena K. Cordeiro, quando da configuração de uma metrópole, tal espaço torna-se o principal emissor de decisões e inovações no setor econômico, social, cultural e político. Assim, os mecanismos de concentração populacional impostos por uma economia de escala, levariam ao aparecimento de novas formas produtivas, realimentando concentrações, uma vez que nesses centros de decisão ampliam-se as possibilidades de acúmulo econômico. Com isso, os desdobramentos do centro metropolitano refletiriam a ação de agentes econômicos na busca por eficiência no processo de controle e aglomeração uma vez que quanto menores forem os investimentos em infra-estrutura nas regiões periféricas, maior será o poder de atração dos centros, ampliando exponencialmente sua força de manipulação da informação ${ }^{72}$.

O crescimento espacial da cidade, associado a uma concentração de capitais cada vez maior, tornou evidente um elevado conjunto de conflitos sociais e culturais, obrigando novas intervenções do poder em maior escala, em um claro "sistema de ordenação e controle sociais, baseado numa ideologia progressista, numa filosofia racionalista e numa estratégia higienista, com alto custo social”"73.

Nesse cenário, a medicina encarregou-se da criação de todo um código de normas de higiene que iam desde o banho e a escovação dos dentes até formas de como dormir, sentar, falar e não apertar as mãos de estranhos ${ }^{74}$. Além disso, desde o final do séc. XIX a literatura médica propunha a esterilização em massa como forma de "terapêutica social" a ser adotada especialmente entre prostitutas, alcoólatras, vagabundos, leprosos, tuberculosos, sifilíticos, epiléticos, cancerosos, loucos e miseráveis, o que acarretaria em pesados custos para o poder público ${ }^{75}$.

Um melhor controle social somente poderia ocorrer mediante a produção de dados estatísticos capazes de dirigir cientificamente a ação reorientadora do Estado.

\footnotetext{
${ }^{72}$ CORDEIRO, Helena Kohn. O centro da metrópole paulistana. Expansão recente. São Paulo, USP, 1980.

${ }^{73}$ BARBUY, H. A cidade-exposição. Op. Cit., p. 70.

${ }^{74}$ Esses seriam hábitos cada vez mais comuns em um ambiente cuja prudência, educação e higiene preponderassem. ROMERO, M. Medicalização da saúde. Op Cit., pp. 80- 2.

${ }^{75}$ Idem, p. 140.
} 
Assim, foi criada em São Paulo a Repartição de Estatística e Arquivo responsável por produzir pesquisas quantitativas em todo o Estado com o objetivo de orientar, de maneira precisa, as ações do poder público quanto a um melhor controle social, reafirmando antigas estruturas de poder.

Foi nesse momento que a antiga cidade colonial viu-se rasgada por grandes avenidas e ruas retificadas, além de grandes prédios públicos estrategicamente colocados, servindo de "monumentos" à modernidade, ao crescimento e ao desenvolvimento.

Se por um lado toda essa racionalidade pautou-se na visibilidade e uniformização, por outro também foi a responsável pela implantação de um verdadeiro "zoneamento social", criando áreas próprias para a elite e para o temido populacho, que deveria ser mantido afastado por ser foco de "propagação da morte". Um exemplo disso, além da própria abertura de bairros destinados a públicos específicos, talvez sejam os parques e jardins abertos pela cidade como o Antarctica e o do Museu Paulista, ambos em estilo europeu, destinados a um público que podia dedicar parte de seu tempo ao ócio. Na prática, imigrantes pobres eram deslocados para a periferia, assim como ex-escravos e toda a sorte de migrantes, enquanto os imigrantes endinheirados que chegassem ao Brasil já com fortuna, ou mesmo que a conquistassem por aqui, eram vistos como empreendedores, gozando de certos privilégios.

O crescimento desordenado da cidade trouxe consigo consequiências pouco abonadoras, como a elevação dos casos de violência. Tratava-se de um enorme contraste em relação à antiga cidade dotada de "pacata sisudez e a hombridade tradicionais" ${ }^{276}$. Assim sendo, em nome da ordem, a polícia perseguia todos aqueles que eram considerados simpatizantes dos Federalistas ou dos revoltosos da Armada, além de agir com total rigor em relação às consideradas perigosas práticas socialistas e anarquistas, trazidas e mantidas no país junto a colônias de imigrantes. Assim, a cidade de São Paulo era protegida por forças policiais ostensivas e secretas, além de

\footnotetext{
${ }^{76}$ DONATO, H. “A cidade de São Paulo em 1894”. Op. Cit., p. 10.
} 
um grande número de soldados do $14^{\circ}$ Regimento de Cavalaria e do $3^{\circ}$ de Artilharia, tudo isso visando garantir a ordem pública e o bom funcionamento das estruturas econômicas privadas. Vale lembrar que, legal e moralmente, todo aquele que pudesse ser visto com um risco à idéia do progresso seria considerado elemento anômalo, devendo ser enquadrado em instituições controladoras como prisões, hospícios e estabelecimentos correcionais ${ }^{77}$.

Não foi a toa que a partir de 1894 as estatísticas criminais produzidas pelo poder público por meio da Repartição de Estatística passaram a incluir classificações para delitos como "anarquistas", ao lado de "gatunos" e "cafetões".

Uma vez instalada a República, as ações de contenção social adotadas visavam a promoção de uma ampla reforma na área educacional. Com a implantação do novo regime, o voto deixou de ser censitário e tornou-se universal, mediante permanência de elementos limitantes da cidadania, como a exclusão das mulheres do processo político e a exigência de alfabetização, ao mesmo tempo em que a Constituição de 1891 não se propunha garantir a educação básica como obrigação do Estado, ficando ela a mercê de práticas coronelísticas. Foi nesse mesmo momento que, por ação de Benjamim Constant, foi criado o Ministério da Instrução, Correios e Telégrafos (1891-92).

Nesse contexto, a criação de estabelecimentos de ensino laicos, pautados no ensinamento científico e prático, em contraposição à lógica monárquica de entregar a religiosos essa tarefa, tornou-se um dos melhores mecanismos de propaganda republicana promovida pela elite em São Paulo.

Posta em vigor em 1892 mediante a vigência da lei $\mathrm{n}^{\circ}$ 88, a reforma educacional em São Paulo começaria a dar seus primeiros frutos dois anos depois, tendo à frente da pasta governamental o Sr. Cesário Motta Jr. A intenção era a ampliação do número de escolas, tendo como referência a Escola Normal da Praça (inaugurada em 02 de agosto de 1894) e o Ginásio do Estado, ambos construídos como "templos do saber", dotados da função de reproduzir a própria idéia de

\footnotetext{
${ }^{77}$ ROMERO, M. Medicalização da saúde. Op. Cit.
} 
República e seu projeto de construção nacional. A intenção última seria a reconciliação do povo com a nação, plasmado em uma pátria ordeira e $\operatorname{progressista}^{78}$.

Outra de suas ações foi a instalação da Escola Politécnica no palacete Três Rios, comprado por 80:000\$000, mesmo em uma época de grandes dificuldades financeiras do estado, impactado com os elevados encargos bélicos decorrentes da Revolta da Armada. Sua criação serviria para sanar a falta de engenheiros que atuariam na abertura de novas ferrovias, obras públicas e expansão da malha urbana. Além disso, instalava-se na cidade de Piracicaba uma Escola Prática de Agricultura, tendo por objetivo o desenvolvimento de pesquisas na área agrícola e a manutenção de São Paulo à frente do progresso agrícola nacional.

Àqueles que não tivessem "direito" ao sistema público de educação receberiam o serviço militar como forma de moldá-los para o mundo do trabalho ${ }^{79}$. Para a elite, o crescimento no número de homens fora do controle oligárquico, como foi em Canudos e no Contestado, era motivo de medo, sendo necessário normatizar o trabalho por meio da disciplina militar ${ }^{80}$.

Ao fazer um balanço do ano de 1894 para a Revista do IHGSP, em comemoração ao centenário do Instituto Histórico e Geográfico de São Paulo, o historiador Hernani Donato apontou ter sido nesse mesmo ano o início da construção do Museu Paulista (também conhecido como "Museu do Ipiranga"), inaugurado no

\footnotetext{
${ }^{78}$ Sobre o tema vale a leitura de: NISKIER, Arnaldo. Educação brasileira: 500 anos de história (15002000). Rio de Janeiro, Consultor, 1995. Também vale a leitura de: LOPES, Eliane Marta Teixeira (org.). 500 anos de educação no Brasil. Belo Horizonte, Autêntica, 2000.

${ }^{79}$ Apesar da previsão do serviço militar existir em território brasileiro desde o período colonial, quando a Câmara de São Vicente promulgou um termo organizando uma milícia formada por colonos e indígenas (1542), seu marco inicial remontaria a 1574 com a Provisão sobre as Ordenanças, obrigando todo o homem com idade entre 14 e 60 anos a servir nas Companhias de Ordenanças. Inúmeras determinações foram postas em vigor durante o império, mas foi em 1908 que uma lei foi assinada instituindo o serviço militar obrigatório no Brasil. Contudo, o novo sistema só foi posto em prática após uma campanha cívica levada a cabo por Olavo Bilac entre os anos de 1915- 6, estabelecendo-se o recrutamento mediante sorteio.

${ }^{80}$ LINHARES, Maria Yedda; SILVA, Francisco Carlos Teixeira da. Terra prometida. Uma história da questão agrária no Brasil. Rio de Janeiro, Campus, 1999.
} 
ano seguinte ${ }^{81}$. A intenção seria instruir de maneira prática o "público pelas coleções expostas e a exploração científica do Estado, especialmente no ramo da zoologia"82, utilizando-se o recurso da observação. Tendo como primeiro diretor o zoólogo alemão Hermann Von Ihering ${ }^{83}$, o Museu tinha como perfil à dedicação a História Natural, sendo construído com dinheiro levantado por meio de três loterias ${ }^{84}$. Chegava ao "fim" mais uma etapa do projeto republicano de somar independência e patriotismo com ciência e instrução.

Para Ana Maria de Alencar Alves os museus criados ao longo do séc. XIX seguiram diferentes temáticas, especialmente devido ao fato de terem sido uma das mais importantes instituições de ação científica. No caso específico do Museu Paulista, a "perda" do apego pela História Natural veio sob orientação do engenheiro Afonso d'Escragnolle Taunay, nomeado como seu Diretor em 1917. Nesse momento São Paulo, detentor de hegemonia política na República, passava por questionamentos internos profundos, cabendo ao Estado, a supressão desses agentes e pensamentos estrangeiros. Assim, buscou-se definir as características de uma São Paulo antiga, especialmente atrelada à idéia de "berço da nacionalidade e o centro de onde esta deveria irradiar-se para o resto do país", utilizando-se do aparato criado no Museu Paulista ${ }^{85}$. Na medida em que o interesse pela história pátria crescia, especialmente até 1922, reafirmando-se o poder republicano em São Paulo, diminuía a presença da História Natural.

Idealizado ainda durante a monarquia como forma de celebrar a Independência, o Museu começou a ser construído sob a idéia de monumento,

\footnotetext{
${ }^{81}$ Vale lembrar que o modelo seguido foi o norte-americano, mesclando avanço do conhecimento com educação pública. Essa talvez tenha sido a grande inovação oriunda dos EUA, diferenciando-os dos países europeus.

${ }^{82}$ DONATO, H. “A cidade de São Paulo em 1894”. Op. cit.

${ }^{83}$ Aparentemente, seu vínculo com a história seria maior que a imaginada por muitos, especialmente se levado em conta que Ihering foi, durante muitos anos, membro participante do Instituto Histórico e Geográfico de São Paulo.

${ }^{84}$ Criada por Laurindo Abelardo de Brito em 1880, ficou conhecida com a "fraudulenta" pois mecanismo legal que estabelecia sua criação destinava o dinheiro arrecadado como investimento em instrução pública primária. Vários municípios pressionaram para que a lei fosse levada à risca, pois assim receberiam parte das verbas.

${ }^{85}$ ALVES, Ana Maria de Alencar. O Ipiranga apropriado. Ciência política e poder: o Museu Paulista (18931932). São Paulo, Humanitas, 2001, p. 28.
} 
mesclando uma função celebrativa com um aspecto instrutivo e científico. Para os monarquistas, a elaboração desse monumento seria um fim em si mesmo (comemoração), enquanto republicanos encaravam-no como um meio, sendo a instrução um fim. Nas palavras de Rangel Pestana, a educação seria uma forma de "regeneração social" ${ }^{86}$. Se por um lado o Museu teria a função de atuar como agente educador de uma população em crescimento, por outro serviria para aculturar uma grande leva de imigrantes, agindo como peça importante de um "quebra-cabeças civilizatório" 87 , especialmente em um país formado por analfabetos, libertos e imigrantes.

A elite de São Paulo estabeleceu os elementos necessários para contar a sua história, bem como a história nacional a partir do local, por meio da trajetória dos seus "grandes homens". Assim, a figura de D. Pedro I teve que dividir espaço com os bandeirantes (especialmente Raposo Tavares e Fernão Dias), encomendados junto ao escultor italiano Luigi Brizzolara. No final "estava montado um discurso heróico que exaltava São Paulo como o berço da nacionalidade e o lugar de onde esta se irradiava para o resto do país" ${ }^{\prime 8}$. Vale lembrar que outras instituições de caráter cultural seguiram o mesmo caminho, amparando-se mutuamente. Este é o caso tanto da recém criada Repartição de Estatística como do próprio IHGSP.

O espírito de progresso era tamanho que na edição da Enciclopédia Meyer Konversation Lexikon, editada na Alemanha naquele mesmo ano, São Paulo era colocada como uma cidade recomendável aos jovens "ansiosos por triunfar na vida", definindo-a como um paraíso de possibilidades, especialmente no comércio. $\mathrm{Na}$ prática o crescimento desse setor foi tamanho que em 07 de dezembro de 1894 foi criada a Associação Comercial de São Paulo, responsável pelo estabelecimento de articulações entre o empresariado paulista e o governo, sendo uma das primeiras

\footnotetext{
86 Para Ana Maria de Alencar Alves, um museu de História Natural mostrava-se necessário para a implantação de um eficiente sistema de ensino, associando-se à recém criada Escola Normal, com o objetivo de formar novos mestres. Idem.

${ }^{87}$ Idem, p. 97.

${ }^{88}$ Idem, p. 176.
} 
entidades de classe na cidade. ${ }^{89}$. Seu prestígio aumentava na mesma proporção do crescimento econômico de São Paulo. Uma das causas defendidas pela instituição ainda no início do séc. XX, quando não existia grande diferença entre a atividade industrial e a importadora, dizia respeito à adoção de medidas protecionistas da agricultura, indústria, comércio e importação.

\section{2- A criação do Arquivo do Estado de São Paulo}

De acordo com Antônio Barreto do Amaral, em seu livro O Departamento de Arquivo do Estado e sua história, esta instituição seria a

"mais antiga repartição pública estadual, possivelmente do Brasil, pois suas origens remontam a setembro de 1721, quando em uma das dependências do Palácio do Governo, o Secretário Gervásio Leite Rebelo, deu início ao arrolamento dos papéis oficiais, para isso escriturando um livro-índice, peça histórica guardada com o maior carinho" ${ }^{90}$.

Criado efetivamente apenas em 1892 com a incumbência de realizar “trabalhos estatísticos, guarda, coordenação, classificação de todos os papéis, documentos e livros atinentes ao direito constitucional, à história política e administrativa, à legislação e geografia de São Paulo e de todos os demais que o governo determinar que ali se depositem" "91, sua função remontaria ao séc. XVIII, mesmo com todas as mudanças administrativas decorrentes das determinações metropolitanas.

\footnotetext{
${ }^{89}$ De acordo com Guia dos documentos históricos na cidade de São Paulo, uma das primeiras vitórias da Associação Comercial ocorrera ainda em 1895 quando da inauguração de uma alfândega seca na cidade, uma antiga reivindicação dos homens de comércio paulista. Tratava-se de um estabelecimento destinado "à liberação de documentos" e, por tanto, facilitador de relações mercantis. NEPS. Guia dos documentos históricos na cidade de São Paulo: 1554- 1954. São Paulo, Hucitec, 1998, pp. 583- 4.

${ }^{90}$ AMARAL, Antônio Barreto do. O departamento de arquivo do estado e sua história. São Paulo, DAESP, 1974, p. 16.

${ }^{91}$ AESP. História do arquivo público de São Paulo; acompanhado da relação dos cidadãos que governaram a província e o estado. São Paulo, São Paulo, Duprat, 1908, p. 13.
} 
Em toda a trajetória política de São Paulo a tarefa de armazenar documentos orientou-se por duas grandes vertentes de atuação. Em 1721, com o desmembramento de São Paulo da capitania de Minas Gerais e a nomeação de D. Rodrigo César de Meneses como Governador e Capitão-General da recém criada Capitania, tornou-se atribuição do governo recolher material original e minutas de textos legais produzidos e remetidos a terceiros, especialmente porque, até então, toda a documentação era acumulada na cidade de Ouro Preto, centro administrativo da antiga Capitania.

Estando Gervásio Leite Rebello à frente da Secretaria de Governo, iniciouse um processo de acumulo de documentos para fins burocrático-administrativos, visando subsidiar as tomadas de decisão do novo governo ${ }^{92}$.

Sempre ocupando as mesmas dependências do Palácio do Governo, inicialmente toda a massa documental foi instalada em um convento jesuíta na capital, confiscado em 1759 por ordem do Marquês de Pombal. Enquanto a administração ocupava o pavimento térreo e superior, a documentação ficou relegada às instalações existentes no subsolo do edifício, situação que persistiu até 1906, quando foi transferido para os fundos (térreo) da igreja dos Remédios e Biblioteca do Estado.

Não tendo esse $1^{\circ}$ prédio o assoalho impermeável, "as lavagens do pavimento superior inundavam o andar térreo, ficando, por esse motivo, bastante estragado grande número de Cartas Régias, Avisos, Regulamentos e Ordens diversas de 1611 a 1761, papéis avulsos e Livros de Registro de Correspondência dos Vice-Reis e Ministros com os antigos Governadores e Capitães-Generais e com os Governos Interinos da Capitania de São Paulo (...) assim como os Livros de Registro de Correspondências dos mesmos Capitães-Generais com os Vice-Reis, Ministros e diversos

\footnotetext{
92 Sobre esse assunto vale salientar que nenhum conjunto documental é produzido dentro de qualquer estrutura administrativa objetivando atender às necessidades inerentes à pesquisa acadêmica, mas sim atender a demandas administrativas. Na prática, o uso de toda essa massa documental por parte dos pesquisadores, entre eles os historiadores, acaba sendo um de seus possíveis "subprodutos".
} 
funcionários da Capitania, os quais representavam verdadeiras preciosidades para a história e geografia (...) ${ }^{, 93}$.

Com a extinção da Capitania de São Paulo em 1748, tudo aquilo que havia sido acumulado pela Secretaria de Governo foi transferido para o Rio de Janeiro, onde permaneceu até 1765 . Toda a documentação que dissesse respeito a negócios que envolvessem a Coroa, e estivessem em andamento, deveria ser remetida ao Governador da praça de Santos ou ao Vice-Rei no Rio de Janeiro. Coube ao Morgado de Matheus (a partir de 1765), reorganizar o material na época em que a Capitania de São Paulo voltou a ter autonomia, aglutinando papéis administrativos que se encontravam esparramados por Minas Gerais, Rio de Janeiro e até mesmo São Paulo. Vale salientar que a reunião de todo esse conjunto não implicou, em hipótese alguma, na elaboração de mecanismos efetivos, por parte do governo da Capitania, para melhor acomodação, preservação e disponibilização dos originais.

Devido à importância informativa do material, em 1842 foi elaborada uma legislação específica sobre a questão, “criando-se” um Arquivo Público. Uma lei foi assinada pelo Barão de Monte Alegre ${ }^{94}$, estabelecendo-se em São Paulo um Arquivo Provincial sob o controle do secretário do governo ${ }^{95}$. Por meio dela, a nova repartição contaria com três seções, sendo uma legislativa, uma administrativa e outra histórica. Caberia a essa última guardar os documentos referentes a acontecimentos notáveis, documentação oficial relativa à independência, notícias úteis referentes a novas descobertas na área de história natural, patentes de inventos, memórias e planos referentes a agricultura, comércio, navegação, indústria, ciências e artes; e "tudo o mais que possa interessar à história” da província (parágrafo $3^{\circ}$,

\footnotetext{
93 AESP. História do arquivo público de São Paulo. Op. Cit., p. 07. Trata-se do primeiro instrumento de pesquisa produzido pelo Arquivo, ainda como Repartição de Estatística e Arquivo.

${ }^{94}$ Trata-se do baiano José da Costa Carvalho (1796-1860) que, além de membro da Regência Trina brasileira (não chegou a cumprir o mandato), foi também Presidente do Conselho de Ministros durante o II Reinado (1849- 52). Tendo seguido carreira jurídica, fixou-se em São Paulo, onde foi acusado de manter fortes vínculos com os interesses portugueses, sendo o mentor intelectual da bernarda de Francisco Ignácio (1822). Colocou-se como força antagônica aos irmãos Andrada, chegando a criara o primeiro jornal impresso de São Paulo, o Farol Paulistano. Para maiores informações ver: VAIFAS, Ronaldo (org.). Dicionário do Brasil imperial. Rio de Janeiro, Objetiva, 2002, pp. 428-9.

95 Trata-se da lei no 196 , de 08 de março de 1842.
} 
art. $6^{\circ}$ ). Também seria atribuição da nova instituição fornecer certidões quando solicitado, mediante pagamento ${ }^{96}$.

Contudo, essa e outras leis correlatas não tiveram efetiva atuação. Em 1842 o então Presidente da Província José Thomaz Nabuco de Araújo pronunciou-se a respeito da lei $\mathrm{n}^{\mathrm{o}} 20$, de 08 de março, quando da abertura dos trabalhos da Assembléia Legislativa Provincial:

"A lei número 20, de 8 de março de 1842, que instituiu o Arquivo Público, ainda não foi executada: aí estão disseminados por diversas Repartições, arquivos não classificados, não apreciados, jazendo no olvido, entregues ao pó e as traças, documentos importantes e preciosos para nossa história, rica de fatos gloriosos e heróicos" $"$.

Historicamente, a trajetória desta instituição foi sempre muito truncada, vivendo o dilema estabelecido entre a formalidade de seu aspecto legal e a realidade do cotidiano administrativo da província, depois estado, de São Paulo. Mesmo com sua criação oficial, o projeto de um Arquivo Público paulista nunca saiu do papel, configurando-se como verdadeira letra morta. A situação tornou-se tão crítica que em 1853 o responsável por toda a documentação acumulada pela administração pública era o porteiro da Secretaria de Governo.

Novamente, durante uma seção de abertura dos trabalhos da Assembléia Legislativa, Josino Nascimento da Silva ressaltava que

"o arquivo confiado atualmente ao Porteiro da Repartição não está em devida ordem como é de desejar. São muitas as incumbências que pesam sobre o Porteiro; obrigá-lo também a serviço de arquivista é exigir demasiado"98.

Em relatório encaminhado à Assembléia Provincial em 1880, o então Secretário dos Negócios do Interior, Sr. José Joaquim Cardozo de Mello, relatava a precariedade do arquivo, encontrando-se o acervo ou entulhado nas salas de

\footnotetext{
${ }^{96}$ Lei estabelecia que o dinheiro arrecadado com tal serviço deveria ser dividido igualmente entre os oficiais e amanuenses após deduzida a quota pertencente à fazenda provincial.

${ }^{97}$ Pronunciamento proferido em 01 de maio de 1852. In: AESP. História do arquivo público de São Paulo. Op. Cit., p. 09.

${ }^{98}$ AMARAL, A. B. do. O departamento de Arquivo. Op. Cit., p. 40.
} 
trabalho, ou no térreo, sem ar nem luz, "a ponto de ficar tudo perdido". Ao que parece, no porão do Palácio do Governo o arquivo ocupava uma sala em forma de palco e platéia de teatro, visto ter servido o espaço a esse propósito em outras oportunidades $^{99}$. Como medida alguma foi tomada, no ano seguinte um novo relatório foi produzido por Laurindo Abelardo de Brito e também encaminhado à Assembléia Provincial, onde se pode obter informações a cerca da condição física de parte do acervo documental da Secretaria de Governo, já muito danificados pela umidade $^{100}$.

Apesar dos esforços para organização e manutenção do acervo, em 1881 uma reforma no prédio do Governo resultou na demolição da sala em que funcionava o arquivo. Após inúmeras desarticulações e fragmentações, o acervo passou por uma reordenação durante o ano de 1882, a pedido do então Presidente da Província, Conselheiro Francisco de Carvalho Soares Brandão. A situação não persistiu por muito tempo, visto o descaso da administração provincial ${ }^{101}$.

Diferentemente dos anos anteriores, em 1886 um Relatório do Presidente da Província, produzido por João Alberto Corrêa de Oliveira e apresentado ao Visconde de Parnaíba (Vice-Presidente da Província) falava que o arquivo encontrase organizado. Vale salientar que, aparentemente, o trabalho pode ser feito após mudanças ocorridas na sede do Palácio do Governo ${ }^{102}$. Inicialmente no térreo, a Secretaria de Governo foi remanejada para o pavimento superior, após este ter sido restaurado, enquanto seu arquivo continuava ocupando as antigas dependências. A ampliação do espaço dedicado à Secretaria seria um reflexo da expansão de suas

\footnotetext{
${ }^{99}$ GOVERNO DE SÃO PAULO. Relatório do Presidente da Província. São Paulo, Tipografia Jorge Secker, 1880, p. 95.

${ }^{100}$ GOVERNO DE SÃO PAULO. Relatório do Presidente da Província. São Paulo, Tipografia Jorge Secker, 1881.

${ }^{101}$ Em uma "Breve história do Arquivo", o então Diretor Ubirajara Dolácio Mendes, apontava para a inexatidão quanto ao êxito da empreitada, apesar das suposições contrárias, pois nova comissão para esse fim foi nomeada em 1885- 6. In: AESP. Boletim do Departamento do Arquivo do Estado de São Paulo. São Paulo, Secretaria da Educação e Saúde, vol IX, 1952.

${ }^{102}$ GOVERNO DE SÃO PAULO. Relatório do Presidente da Província. São Paulo, Tipografia Jorge Secker, 1886.
} 
atividades, devido especialmente ao incremento da imigração e da necessidade de trabalhos estatísticos.

A partir da criação oficial da Repartição de Estatística e do Arquivo do Estado (1892) ${ }^{103}$ essa instituição passou a receber e incorporar em seu acervo documentos de origens e naturezas variadas, oriundos das diversas secretarias, cartórios, poder Judiciário e documentação privada, atuando como grande receptáculo administrativo e histórico de São Paulo. Por seu decreto de criação a nova instituição ficava incumbida dos

"trabalhos estatísticos, guarda, coordenação, classificação de todos os papéis, documentos e livros atinentes ao direito constitucional, à história política e administrativa, à legislação e geografia de São Paulo e de todos os demais que o governo determinar que ali se depositem"104.

O Decreto $\mathrm{n}^{\circ}$ 30, de 10 de março de 1892, assinado por J. A. de Cerqueira Cezar, subordinava a Repartição à Secretaria do Interior. Seu acervo original era composto pelo arquivo da extinta Secretaria do Governo, com exceção feita aos documentos remetidos às Secretarias de Estado específicas, criadas após a extinção da Secretaria de Governo ${ }^{105}$.

No mesmo ano, uma resolução foi assinada também por Cerqueira Cezar estabelecendo os serviços que deveriam ser prestados pela Repartição de Estatística e Arquivo ${ }^{106}$. O seu art. $2^{\circ}$ determinava que em seu acervo fossem depositados os originais da Constituição estadual e respectivos projetos; originais de todas as leis, decretos e resoluções; originais dos regulamentos e atos do poder Executivo; relatórios apresentados pelos Secretários e Presidente de Estado; mensagens e propostas ao Legislativo; documentos referentes à propriedade dos bens do Estado;

\footnotetext{
${ }^{103}$ Sua criação fez-se mediante decreto $\mathrm{n}^{\circ} 28$, de 01 de março de 1892 , responsável por organizar as Secretarias do Interior, Justiça e Agricultura. No mesmo dia entrava em vigor também o decreto $\mathrm{n}^{\circ} 29$, estabelecendo as diretrizes gerais da Secretaria da Fazenda, além de reorganiza o Tesouro estadual.

${ }^{104}$ AESP. História do arquivo público de São Paulo. Op. Cit., p. 13.

${ }^{105}$ O fim da Secretaria de Governo implicou na criação das Secretarias da Agricultura, Justiça, Fazenda e do Interior. Aos olhos dos administradores da Repartição seria um erro vê-la como apêndice dessas quatro Secretarias, subordinando-a aos quatro secretários.

${ }^{106}$ Trata-se da resolução no 30, de 10 de março de 1892.
} 
processos de responsabilidade contra altos funcionários; processos sobre conflitos de jurisdição; coleção dos Diários Oficiais da República e de São Paulo; cópia das atas de fundação dos edifícios públicos; relatórios e memórias apresentadas por comissões; documentos referentes ao descobrimento de riquezas naturais e desenvolvimento das ciências, letras e artes, além da agricultura, comércio, indústria e navegação do estado; mapas geográficos; livros, documentos e papéis que tivessem pertencido a repartições extintas; documentos históricos de qualquer natureza. Além disso, o art. $17^{\circ}$ estabelecia que dois exemplares de cada trabalho publicado pela imprensa do Estado deveriam ser remetidos à Repartição.

Caberia a ela também, conforme o art. $12^{\circ}$, os serviços de guarda, classificação e coordenação dos papéis ali depositados, além da organização de catálogos. Quanto à consulta ao material, esta deveria ocorrer mediante autorização do Diretor, e no caso de serem documentos classificados como "reservados", apenas com anuência do próprio Secretário do Interior (art. $20^{\circ}$ ).

Contudo, por não conseguir realizar a contento os trabalhos estatísticos previstos no decreto original, um novo decreto foi posto em vigor, reorganizando a recém criada Repartição ${ }^{107}$. Saliente-se que desde o seu efetivo surgimento, o arquivo era, de fato, apenas sua $3^{\mathrm{a}}$ seção, cabendo a esta, além da "guarda do Arquivo do Estado e a organização anual dos respectivos catálogos", a "função" de responder ofícios da Secretaria e do Presidente do Estado, e emitir certidões. Às outras duas seções caberiam todos os trabalhos estatísticos de São Paulo, ficando a $1^{a}$ seção incumbida das estatísticas referentes a população, imigração/emigração e colonização, e a $2^{\mathrm{a}}$ com os trabalhos estatísticos referentes ao desenvolvimento industrial, comercial e agrícola, renda pública do Estado e municípios, instrução pública, demografia sanitária, de estabelecimentos de beneficência, caridade, correios e telégrafos, água e esgoto.

\footnotetext{
107 Trata-se do decreto $\mathrm{n}^{\mathrm{o}} 116$, de 01 de outubro de 1892, assinado pelo então Presidente de Estado, Sr. Bernardino de Campos, que dotou a Repartição de 25 funcionários distribuídos em três seções, além da nomeação de 167 agentes municipais responsáveis por fornecer dados quantitativos necessários para a confecção de mapas estatísticos. Para esses cargos deveriam ser escolhidos, preferencialmente, os próprios Secretários dos municípios. MENDES, U. D. "Breve histórico do Arquivo". Op. Cit.
} 
Pelo art. $2^{\circ}$ do decreto 116 caberia à Repartição organizar "os trabalhos estatísticos" assim como "sua impressão e publicação, além da guarda de documentos e papéis, oficiais ou não, que interessarem, sob qualquer ponto de vista, à história de São Paulo em especial, e do Brasil em geral".

A preocupação quase que exclusiva com a coleta e produção de dados estatísticos fica cada vez mais evidente mediante a leitura da legislação em vigor à época. Pelo decreto $\mathrm{n}^{\mathrm{o}} 124$, de 11 de novembro de 1892, e também assinado por Bernardino de Campos, entrou em vigor o regulamento da Repartição. Por meio dele explicitava-se a necessidade dos trabalhos estatísticos, imprescindíveis para que se pudesse conhecer e aproveitar as exatas

$$
\begin{aligned}
& \text { "condições físicas, econômicas industriais, comerciais, } \\
& \text { políticas, administrativas, morais e intelectuais do Estado de } \\
& \text { São Paulo; e o da guarda de documentos e papéis, oficiais ou } \\
& \text { não, que interessarem, sob qualquer ponto de vista, à história } \\
& \text { de São Paulo, em especial, e do Brasil, em geral, dando-lhes a } \\
& \text { máxima publicidade""108. }
\end{aligned}
$$

Caberia à Repartição fazer o recenseamento da população do Estado, além publicar anualmente relatórios de trabalho. Quanto à $3^{\mathrm{a}}$ seção, passou também a ser de sua atribuição emaçar os documentos existentes e encaderná-los; emitir certidões e produzir índices cronológicos do material.

Se a intensificação da produção cultural em São Paulo durante os anos 1870 e 1880 não significou a imediata ruptura quanto à primazia cultural oriunda do Rio de Janeiro, um novo ambiente cultural, dotado de características próprias, passava a ser produzido. Tais características poderiam ser constatadas mediante os quadros estatísticos produzidos nos primeiros anos da República. Originalmente encaminhados ao poder central, passaram a ser gradativamente produzidos de maneira independente, atendendo a interesses das lideranças políticas locais, representando uma ruptura formal entre a Repartição de Estatística de São Paulo e a nacional.

${ }^{108}$ Parágrafo $1^{\circ}$, art. $1^{\mathrm{o}}$, do decreto $\mathrm{n}^{\mathrm{o}} 124$, de 11 de novembro de 1892. 
Pelo teor do relatório apresentado pela Secretaria do Interior ainda no ano de 1892, seria possível uma visão mais precisa do papel que deveria desempenhar a questão estatística nas atividades da Repartição. Segundo o Secretário Vicente de Carvalho tratava-se de uma importante ferramenta para legisladores e administradores, inclusive com forte caráter científico e eugênico.

"Poderá ela fornecer-nos dados precisos da população e suas condições, físicas, intelectuais e sociais, sua densidade e profissões, proporção da mortalidade e dos nascimentos; da salubridade nas várias zonas do território, e das moléstias que mais prejudicialmente as afetam; do desenvolvimento ou decadência das várias indústrias, e suas causas prováveis; da justa proporcionalidade dos impostos; das finanças do estado e de cada município; desenvolvimento médio dos seus recursos com relação a prazos determinados; da instrução pública e particular; dos crimes cometidos, classificados pela idade, sexo, nacionalidade, instrução e profissão dos delinqüentes, causas conhecidas que os provocaram; da imigração e emigração; etc, etc..."109

Uma vez solucionado os entraves burocráticos iniciais, a Repartição pode dedicar-se à sua verdadeira vocação. A análise das correspondências enviadas pelo primeiro Diretor da Repartição, Sr. Francisco Augusto da Cunha, demonstra que, já no início das atividades do órgão, as questões referentes à produção estatística mostravam-se como prioritárias. Apesar de tratarem de assuntos administrativos, os mais variados, indo desde questões burocráticas como o envio de relatório de faltas não justificadas de funcionários, até pedidos para a remessa de cópias de leis, anais, relatórios, exemplares da Constituição estadual e exemplares de Diários Oficiais, as minutas de correspondências ativas apontam para a maioria esmagadora de cartas e ofícios enviados pela Repartição solicitando o envio de dados estatísticos referentes a nascimentos e óbitos, entrada de imigrantes na Hospedaria, movimentação populacional em Núcleos Coloniais, relatórios geográficos, movimentos de escolas (boletins mensais), atividades policiais, relação e movimento de bibliotecas e salas

\footnotetext{
${ }^{109}$ GOVERNO DE SÃO PAULO. Relatório da Secretaria dos Negócios do Interior. São Paulo, Tipografia Vandorden, 1892, pp. XII- XIII.
} 
de leitura, assentamento em livros de registros de cemitérios, mapas de eleitores, nomeação de agentes censitários, produção econômica por município, receitas e despesas da Câmara (balancetes), registros de exportação (tanto para outros países como outros estados), dados sobre produção jornalística, dados sobre iluminação pública, existência de institutos de crédito, serviço telefônico, e movimento de estradas-de-ferro $^{110}$. Na visão do segundo Diretor da Repartição, Antônio de Toledo Piza, a estatística serviria como "um dos ramos do serviço público mais importantes que uma Nação civilizada, um Estado ou uma Província possa estabelecer" ${ }^{\text {,11. }}$.

A busca em todo o Estado por dados quantificáveis se mostrou uma constante nos registros de correspondências dos Diretores da Repartição, trocadas especialmente com membros das administrações municipais. Solicitação de informações para a confecção dos mapas estatísticos eram feitas às mais variadas instituições, fosse em relação aos alienados no hospício de Juqueri, fosse sobre instituições escolares particulares e serviços telegráficos disponíveis no estado. Assim, dados sobre a crescente produção jornalística em São Paulo poderiam ser utilizados para demonstrar o evidente desenvolvimento urbano por que atravessava o estado. Para a confecção de relatórios sobre hábitos e consumo alimentar da população paulista, a Repartição solicitava o envio de questionários próprios. Assim, para a mensuração da quantidade de carne ingerida pela população, a Repartição solicitou a todas as prefeituras do interior o envio de planilhas específicas com o intuito de consolidar os dados referentes ao volume de gado abatido, e assim estimar o ritmo alimentar da população ${ }^{112}$.

Em relatório da Secretaria dos Negócios do Interior encaminhado em 1894, o então Secretário Cesário Motta Jr apontava para a importância do trabalho estatístico pois serviria para demonstrar o "desenvolvimento crescente da população

\footnotetext{
${ }^{110}$ Acervo AESP. Repartição de Estatística e Arquivo (correspondências), E 01434, E 01438.

111 GOVERNO DE SÃO PAULO. Relatório da Secretaria dos Negócios do Interior. São Paulo, Tipografia Vandorden, 1895, p. 10.

${ }^{112}$ Acervo AESP. Repartição de Estatística e Arquivo (ofícios expedidos), E 11856.
} 
de São Paulo, durante os tempos coloniais e no primeiro quarto deste século"113. A grande dificuldade no recenseamento dos habitantes da capital vinha do fato de "população ignorante" temer "que o desejo que tinha o Governo de conhecer os membros de uma casa fosse para uma coação ao serviço militar" ${ }^{\text {"114. }}$.

Uma queixa recorrente em quase todos os relatórios encaminhados por Toledo Piza ao governo de São Paulo residia no fato de as Câmaras Municipais e registros civis não enviarem as informações necessárias à Repartição. Parte dos motivos disso era atribuída ao fato de não existir uma obrigação legal para tal encaminhamento.

O envolvimento da Repartição com a questão da produção de quadros estatísticos sobre São Paulo era tamanho que esse Diretor chegou a descrever em seu relatório encaminhado ao Secretário do Interior que, como o trabalho na $3^{\mathrm{a}}$ seção da Repartição não era urgente, "os seus empregados são chamados durante certa parte do ano a auxiliar os da $1^{\mathrm{a}}$ e $2^{\mathrm{a}}$ seção na confecção dos mapas destinados a aparecer no relatório anual da repartição" ${ }^{115}$. Nessa época o Toledo Piza elaborava dois tipos de quadros estatísticos, sendo um econômico (produção, comércio exterior, Núcleos Coloniais, sistemas ferroviários) e um moral (instrução e assistência pública, caridade particular, caixas econômicas).

Em 1909, sob a direção de Adolpho B. de Abreu Sampaio, a Repartição mantinha sua atuação de instituição responsável pelos quadros estatísticos do estado. O poder associado a isso era tamanho que, apenas para se ter uma pálida idéia, cabia à Repartição auditar os dados fornecidos pelos diferentes órgãos e instituições, especialmente porque, a partir deles é que seria, ou não, liberado verba pública destinada em orçamento para o auxílio a organizações privadas. Esse é o caso de um ofício enviado por Abreu Sampaio a José Manoel da Silva Villelas, provedor da Santa Casa de Misericórdia da cidade de Palmeiras. Pelo teor expresso nessa

\footnotetext{
${ }^{113}$ GOVERNO DE SÃO PAULO. Relatório da Secretaria dos Negócios do Interior. São Paulo, Tipografia Vandorden, 1892, p. CXXXVI.

${ }^{114}$ Idem, p. CXXXVII.

${ }^{115}$ GOVERNO DE SÃO PAULO. Relatório da Secretaria dos Negócios do Interior. São Paulo, Tipografia Vandorden, 1897, p. 08.
} 
correspondência o Diretor da Repartição deixava claro que o recebimento de dinheiro público aprovado pelo Congresso do Estado estava vinculado ao correto preenchimento e envio de questionário sobre o funcionamento da instituição ${ }^{116}$.

Tal mecanismo persistiu pelo menos até 1915, devido à lei orçamentária em vigor. De acordo com essa legislação, para que as Santas Casas, asilos e institutos de benemerência pudessem receber dinheiro do estado, era necessário que cumprissem algumas formalidades, como possuir um relatório do Serviço Sanitário estadual além de fornecer informações à Repartição de Estatística, referentes ao número de sócios, volume de receitas e despesas, relação de ativos, movimentação hospitalar, nacionalidade e sexo dos pacientes, assim como suas respectivas idades, e seu quadro de funcionários ${ }^{117}$.

Outro exemplo desse poder de controle pode ser lido em ofício de 19 de julho de 1899, enviado por Antônio de Toledo Piza ao Secretário do Interior, Sr. José Pereira de Queiroz. Por meio dele o Diretor denunciava irregularidades no Núcleo Colonial de Sabaúna, situado na cidade de Mogi das Cruzes, onde mortos eram enterrados sem que fossem feitos registros civis de óbito pelo escrivão de $\mathrm{Paz}^{118}$.

Com relação a esses relatórios e quadros estatísticos produzidos pela Repartição, vale a pena destacar sua importância enquanto peça de propaganda de uma São Paulo republicana e "moderna", apresentando o paulista como uma exceção de progresso e liberdade diante a realidade nacional ${ }^{119}$. Minutas de ofícios mostram que em 1910 boa parte desses levantamentos referentes a São Paulo foram publicados e remetidos a diversas embaixadas e missões diplomáticas do Brasil em

\footnotetext{
${ }^{116}$ Acervo AESP. Repartição de Estatística e Arquivo (ofícios expedidos). E 11856, p. 110, minuta de ofício datada de 30 de setembro de 1909.

${ }^{117}$ No acervo do AESP existem "processos" para liberação de recursos públicos para instituições de benemerência que podem ser encontrados no fundo Secretaria do Interior. C 7015.

${ }_{118}^{18}$ Acervo AESP. Secretaria do Interior. C 7006.

${ }^{119}$ Outra importante peça de divulgação desse espírito de modernidade paulista foi sua imprensa. Inúmeros periódicos foram produzidos em São Paulo, como foi o caso do Almanaque literário paulista, criado por José Maria Lisboa e editado entre os anos de 1876 e 1885. Sua intenção, expressa pelo criador logo na introdução do primeiro volume, seria produzir "um livro curioso e interessante, escrito simplesmente por Paulistas e sobre assuntos da província" (p. III).
} 
todo o mundo, servindo como subsídio "diplomático", fosse para fomentar a entrada de imigrantes, fosse para trazer investimentos estrangeiros, fosse para divulgar a imagem do "grande Estado bandeirante", agindo como a "locomotiva do país", moderna e pujante ${ }^{120}$. Em alguns casos, conforme apresentado em relatório ao Sr. Jorge Tibiriçá, então Presidente de São Paulo, os dados estatísticos coletados e organizados pela Repartição apresentavam incongruências, especialmente devido ao fato das populações do norte e litoral do Estado "manterem-se ainda refratárias ao registro dos nascimentos e casamentos" $" 121$.

Na prática, o termo "arquivo" no nome da Repartição vinha apenas como alusão à existência de um "depósito" de documentos, visto que toda a base de seu trabalho voltava-se à produção de dados estatísticos, visando a produção e acúmulo de dados úteis para a administração pública. A documentação aí existente servira como elemento subsidiário ao papel administrativo da Repartição, qual fosse, o de auxiliar na centralização administrativa e eventual tomadas de decisão por parte do poder político central. Uma reformulação desta situação veio apenas em 1911. Tratou-se do decreto $\mathrm{n}^{\circ} 2.187$, de 26 de dezembro, assinado pelo então Presidente M. J. Albuquerque Lins, alocando na "nova" instituição 32 funcionários. Por meio de seu art. $2^{\circ}$ a Repartição ficaria incumbida de

\begin{abstract}
"coligir, apurar, organizar e publicar todos os dados e informações estatísticas de caráter público ou privado, que tenham relação direta com as condições físico-naturais, demográficas, econômico-financeiras, políticas, intelectuais e morais no Estado".
\end{abstract}

Caberia a ela também a publicação de relatórios mensais, anuários estatísticos e "todos os documentos interessantes para a história e costumes nacionais" $\left(\operatorname{art} .3^{\circ}\right)$.

Nessa oportunidade, a Repartição passou a contar com quatro seções, cabendo à primeira os levantamentos estatísticos do serviço público, estatística

\footnotetext{
${ }^{120}$ Acervo AESP. Repartição de Estatística e Arquivo (ofícios expedidos). E 11856, pp. 185-6.

${ }^{121}$ GOVERNO DE SÃO PAULO. Relatório da Secretaria dos Negócios do Interior. São Paulo, Tipografia do Estado de São Paulo, 1907, p. 64.
} 
moral (movimento policial e judiciário, instrução, jornalismo, bibliotecas, associações de mutualismo e seguros e benemerência), estatística populacional e a consolidação de dados referentes ao Serviço Sanitário. À segunda seção ficaria a incumbência de produzir informações quantitativas referentes aos serviços econômico-financeiros (fonte e distribuição de renda, finanças do estado, casa de crédito, meios de transporte e comunicações). A terceira seção teria a mesma função da segunda, apenas voltando suas atenções à produção agrícola e industrial em geral, colonização de terras, volume e descrição de produtos exportados/importados, comércio e alimentação pública.

A quarta seção preservou as mesmas atribuições de regulamentos anteriores referentes ao recolhimento e guarda de documentos, acrescentando-se apenas que além da guarda de "documentos históricos" produzidos pelo poder público, deveriam ser preservados aqueles de natureza privada que pudessem servir à história de São Paulo e do Brasil. Assim, o art. $19^{\circ}$ estabelecia a necessidade de se criar uma área específica para a guarda de documentos doados por particulares, corporações ou municípios, e que fossem de interesse para a vida nacional e do estado ${ }^{122}$. Uma preocupação técnica que aparece nesse texto legal pela primeira vez. $\mathrm{O}$ art. $15^{\circ}$ do decreto estabelecia que todos os documentos que fossem recolhidos ao arquivo deveriam conter inventário específico, tornando possível a conferência e acesso ao material.

A primeira vez que as preocupações referentes à seção responsável pelo Arquivo vieram antes das demais seções estatísticas foi no Relatório da Secretaria dos Negócios do Interior de 1904. Produzido pelo secretário José Cardoso de Almeida, ele apontava para a necessidade de colocar a Repartição em contato com o público,

\footnotetext{
${ }^{122}$ É importante perceber como a teoria arquivística desse momento caminhava próxima à lógica dos museus. Por esse decreto, os documentos mais notáveis deveriam ser expostos em um "mostruário paleográfico" disponível aos visitantes. Apesar de não definir o que viria a ser um "documento notável”, a postura da instituição, especialmente em relação às suas publicações, aponta para a exibição de documentos referentes a datas significativas na história local ou nacional, bem como assinados por homens ilustres.
} 
"uma vez que os documentos, ali conservados, interessam muito a certa ordem de estudos e sempre se procuram para consultar. Não parece razoável guardá-los, negando-lhes a cópia, ou mesmo o exame, a pessoas que os queiram aproveitar, para fins científicos"

Apesar da produção de planilhas e mapas estatísticos ser uma de suas principais atribuições e contribuições à administração central, em ofício endereçado ao Secretário do Interior e Justiça, Sr. Bento Bueno, o Diretor Antônio de Toledo Piza cobrava uma solução legislativa para os "conflitos" de interesses surgidos entre a Repartição de Estatística e a Repartição de Higiene. Isso ocorria porque ambas as instituições acabavam por levantar dados estatísticos, visto que a Saúde Pública tinha dentro de seus quadros uma seção específica destinada à produção e análise demográfica. A solução encontrada pelo Diretor seria a elaboração de uma lei que estabelecesse os limites de atuação para ambas ${ }^{124}$.

Se em relação a uma parcela de suas atribuições, a Repartição de Estatística gozou de certa estabilidade desde sua criação, o mesmo não poderia ser dito quanto às suas instalações. Durante um bom período de existência a instituição ocupou a parte inferior do Palácio Presidencial, no bairro dos Campos Elíseos, onde era comum a deterioração e o expurgo de documentos devido à ação da umidade decorrente da água que escorria do assoalho, vindo do andar superior, especialmente quando o piso era lavado ${ }^{125}$.

Nas palavras de Antonio de Toledo Piza, os documentos da Repartição estiveram por vários anos sujeitos às traças e "inundações devido às lavagens do Palácio, na parte habitada por cima do Arquivo", problema esse que poderia ser evitado colocando-se "um teto sobre as estantes".

"Entre tantos papéis velhos, muitos deles seculares, há grande número que muito interessa à história de São Paulo

\footnotetext{
${ }^{123}$ GOVERNO DE SÃO PAULO. Relatório da Secretaria dos Negócios do Interior. São Paulo, Tipografia Vandorden, 1904, p. 178.

${ }^{124}$ Acervo AESP. Repartição de Estatística e Arquivo (correspondências), E 01438, pp. 159- 161. Minuta de ofício de 05/ 09/ 1900.

${ }^{125}$ AMARAL, A. B. Op. Cit., p. 52.
} 
durante os tempos coloniais. É de alta conveniência a publicação desses documentos, já para salvá-los da ação do tempo, já para o conhecimento dos amantes do estudo da história pátria. Pretendo iniciar a publicação no corrente ano; 'porém antes de começar este importante trabalho preciso arrecadar alguns documentos que pertencem ao Arquivo e que se acham fora dele, em mãos de particulares nesta Capital e na Secretaria de Governo Federal no Rio de Janeiro. Só depois de todos eles arrecadados e arranjados por ordem cronológica se poderá dar princípio à sua publicação de modo a torná-la útil e de fácil compreensão para o leitor"126.

Foi apenas em 1906 que o Arquivo mudou de sede, indo para os fundos da igreja dos Remédios e Biblioteca do Estado, saindo dos porões do antigo Palácio do Governo.

Desde 1894 o Diretor, em relatório da Repartição de Estatística à Presidência do Estado, deixava claro que "a porção do Palácio presidencial, em que está o Arquivo, não satisfaz o fim a que foi destinada; o espaço é pequeno, acanhado, não comporta estantes suficientes para acomodar os papéis amassados (...)”. Problema semelhante foi apontado por Francisco de Assis Barbosa, também Diretor da instituição, em relatório de 1976, que apontava como um dos principais problemas do Arquivo como sendo a "deficiência de instalações, vivendo em casa alugada, e assim mesmo inadequada para a custódia de documentos de valor permanente ou histórico, produzidos pela administração (...)"127.

As instalações, por vezes, mostravam-se tão precárias que o Secretário do Interior, em 1904, Sr. José Cardoso de Almeida, chegou a receber um ofício solicitando que a Repartição de Obras Públicas retirasse parte do assoalho das dependências da Repartição de Estatística e Arquivo para que pudesse ser feita a

\footnotetext{
${ }^{126}$ GOVERNO DE SÃO PAULO. Relatório da Secretaria dos Negócios do Interior. São Paulo, Tipografia Vandorden, 1892.

${ }^{127}$ WITTER, José Sebastião. Arquivo e história. O Arquivo do Estado de São Paulo na administração e na história. Tese de Livre Docência apresentada na FFLCH da Universidade de São Paulo, 1981.
} 
remoção de um rato morto "cujas exalações podem comprometer a saúde dos empregados" $" 128$.

Por ser a instituição pública detentora de toda a documentação da extinta Secretaria de Governo, além de receber documentos produzidos/acumulados de todas as demais, a Repartição tornou-se referência para os municípios do Estado quanto à sua história e o estabelecimento de seus limites geográficos. Especialmente em relação aos anos compreendidos entre 1899 e 1905 foram comuns os ofícios em respostas a questionamentos referentes aos efetivos limites de municípios, bem como a data de elevação de freguesias em vilas ${ }^{129}$.

Antônio de Toledo Piza foi o Diretor da Repartição de Estatística e Arquivo durante seus primeiros anos (período compreendido entre os anos de 1894 e 1905). Membro de família ilustre em São Paulo, nascido na cidade de Capivari, interior do estado, mostrou-se um republicano convicto, sendo inclusive presidente do Clube Republicano de Porto Feliz e seu delegado na Convenção de Itu (1873).

Como estudante, foi para os Estados Unidos em 1875 cursar engenharia civil na Universidade de Cincinati (Ohio). Já formado, trabalhou na construção de diferentes estradas-de-ferro. Foi nessa época que Toledo Piza tornou-se um dos grandes divulgadores do imaginário norte-americano no Brasil ${ }^{130}$. A lógica política estadunidense impressionou-o profundamente, fosse em relação à participação das elites financeiras no processo governamental, fosse no refinamento técnico utilizado para a exploração de minérios, fosse nos mecanismos eleitorais adotados nos EUA.

Regressando ao Brasil em 1880, exerceu a atividade de engenheiro, sendo contratado pela Joaquim de Salles \& Comp. para atuar como seu representante na compra de equipamentos destinados à implantação da futura cervejaria Antarctica (1885). Regressando novamente ao Brasil, responsabilizou-se pela montagem desse material e pela inicialização das atividades da fábrica.

\footnotetext{
128 Acervo AESP. Ofício datado de 09 de dezembro de 1904, encaminhado por Antônio de Toledo Piza ao Secretário José Cardoso de Almeida. Secretaria do Interior. C 7010.

${ }^{129}$ Ver: Acervo AESP. Repartição de Estatística e Arquivo (correspondências), E 01438.

${ }^{130}$ Esse posicionamento de quase idolatria pode ser constatado mediante a leitura de seus artigos publicados no jornal Província de São Paulo entre os anos de 1886 e 1887.
} 
Logo ao ser nomeado Diretor da Repartição de Estatística e Arquivo, em maio de 1893, Toledo Piza iniciou contatos com os diferentes municípios de São Paulo para solicitar dados quantitativos referentes a nascimentos e óbitos. Toda a correspondência registrada em livros borrador era endereçada aos Oficiais de Registro Civil, levando-se em conta o parágrafo $7^{\circ}$ do art. $3^{\circ}$ do Regulamento do Arquivo. Dos aproximadamente 450 ofícios registrados em livro próprio referentes à sua administração, $90 \%$ delas diziam respeito a solicitações de informações estatísticas $^{131}$.

Se inicialmente, cabia ao Diretor redigir manualmente e enviar os questionários sob a forma de ofício, um a um, com o tempo esses formulários passaram a ser impressos nas oficinas do Diário Oficial, dando maior agilidade ao processo $^{132}$.

Durante parte de sua vida dedicou seus estudos ao período colonial brasileiro, estendendo-se até o início do império. Uma obra sua intitulada Questões de divisas entre São Paulo e Minas Gerais foi vista por muitos como um importante trabalho e "valioso elemento de defesa dos nossos direitos sobre extensos territórios que nos tem sido tomados pelas constantes invasões dos povos mineiros". O próprio Toledo Piza alegava "ter prestado um serviço ao meu Estado e servido também à causa do direito e da justiça"133.

Originalmente publicado no jornal Correio Paulistano (18/ 09/ 1898), sob responsabilidade do próprio autor, que era colaborador do jornal, a obra passou por alterações visando sua publicação, recebendo o acréscimo de dois artigos assinados por Orville A. Derby ${ }^{134}$. Tratou-se de um levantamento junto ao acervo da

\footnotetext{
${ }^{131}$ Para maiores informações ver: AESP, Repartição de Estatística e Arquivo (correspondências), E 01434.

${ }^{132}$ A cada novo relatório estatístico produzido pela Repartição, uma cópia era enviada às Câmaras Municipais e demais "colaboradores", conforme pode ser percebido com a leitura das minutas de ofícios registradas no volume E 01438, referente à Repartição de Estatística e Arquivo (correspondências). Acervo AESP.

${ }^{133}$ PIZA, Antônio de Toledo. Questões de divisas entre São Paulo e Minas Gerais. São Paulo, Tipografia do Correio Paulistano, 1898, p. 03.

${ }^{134}$ Nascido nos Estados Unidos, veio ao Brasil pela primeira vez em 1869 para integrar uma expedição geológica à Amazônia (Expedição Morgan). Fixando-se no país, foi o responsável pela organização do acervo de mineralogia e paleontologia do Museu Nacional, no Rio de Janeiro. Posteriormente, dirigiu e fundou $a$ Comissão Geográfica e Geológica de São Paulo, atuante entre os anos de 1886 e 1904, e o Serviço Geológico
} 
Repartição quanto às divisas do estado de São Paulo e Minas Gerais a pedido do então Presidente de Estado, Dr. Bernardino de Campos. Em seu texto, Toledo Piza apontava para a defesa do federalismo, rendendo honras às ações de Santa Catarina e Paraná, Mato Grosso e Amazonas, sobre as deliberações de seus limites sem precisar da intervenção do poder central. "Os Estados são hoje autônomos, quase soberanos e não mais precisam do poder central, inerte ou egoísta, para os remédios aplicáveis aos males que sofrem" ${ }^{\prime 35}$.

Membro fundador do Instituto Histórico e Geográfico de São Paulo, atuou de maneira decisiva para a criação de sua Revista, exercendo cargo de direção dessa publicação até 1905, quando da sua morte. Foi nessa revista que Toledo Piza publicou artigos como "O suplício de Chaguinhas" ${ }^{136}$ e a "Bernarda de Francisco Ignácio", levante ocorrido em São Paulo pouco antes da Independência, tendo sido um dos motivos que fizeram vir a São Paulo o então Príncipe Regente, D. Pedro de Alcântara ${ }^{137}$. Também foi por seu intermédio que os manuscritos de Joaquim Costa Silveira, sobre a região de Cuiabá, foram divulgados ao público, em uma clara demonstração de sua ação no tocante ao recolhimento e salvaguarda de acervos documentais junto ao acervo do IHGSP. Tratava-se de material encontrado pelo próprio Toledo Piza "misturado" nos papéis do Tenente- General José Arouche, "salvando-o da ação destruidora do tempo"138. Para a efetiva publicação foi necessário o apoio da Biblioteca Nacional, possuidora de outra cópia do material, o que permitiu completar eventuais "lacunas".

Na ocasião de sua morte (1905), o Correio Paulistano dizia em nota necrológica publicada em 09 de novembro:

e Mineralógico do Brasil. Vale a leitura de algumas das suas obras, entre elas: DERBY, Orville A. Limites entre São Paulo e Minas Gerais. São Paulo, Typographia Brazil, 1920. LAMEGO, Alberto Ribeiro. Orville Adelbert Derby, 1851-1951; alguns aspectos da sua obra. Rio de Janeiro, Departamento Nacional Produção Mineral, 1951.

${ }^{135}$ Idem, p. 42.

${ }^{136}$ Esse artigo pode ser encontrado em: IHGSP. Revista do Instituto Histórico e Geográfico de São Paulo. São Paulo, vol. 5, 1899/ 1900.

137 A primeira versão desse texto foi publicado no vol. I dos Documentos interessantes publicado pela Repartição de Estatística e Arquivo do Estado de São Paulo em 1894. Na Revista do Instituto Histórico e Geográfico de São Paulo o mesmo texto pode ser encontrado no vol. 7, de 1902.

${ }^{138}$ Revista do Instituto Histórico e Geográfico de São Paulo. São Paulo, vol. 4, 1898- 9, p. I. 
“O serviço da Repartição de Estatística que é hoje um modelo entre os existentes no Brasil, tão bem organizado está, prestando-se mesmo de modelo às repartições iguais de outros Estados, foi trabalho seu, fruto da sua determinação de infatigável e não é pequeno o subsídio que para a reconstrução histórica de nosso passado nos legou a sua pena de estudioso para quem não possuía segredos os velhos documentos nem a crônica complicada e vaga dos primeiros tempos coloniais"139.

Funcionando por muitos anos sob a tutela da Secretaria do Interior, quando da sua extinção ${ }^{140}$ (1931), o Arquivo foi entregue, por um curto período, à Secretaria de Justiça ${ }^{141}$. Isso ocorreu pois, com o fim da Secretaria do Interior, todas as repartições e serviços que seriam incorporados à Secretaria da Educação e Saúde Pública foram relacionados no primeiro decreto, ficando as demais sob o controle da pasta da Justiça. A correção veio poucos meses depois, incorporando a Repartição à Secretaria de Educação e Saúde Pública.

Uma nova reestruturação administrativa foi levada a cabo em 1938, já sob a lógica do Estado Novo e sua preocupação com a eficiência administrativa ${ }^{142}$. Por meio dela foi criado o Departamento de Arquivo, sendo retiradas suas atribuições estatísticas (criação do Departamento Central de Estatística) ${ }^{143}$. Com o estabelecimento de um órgão especificamente responsável pela elaboração dos dados estatísticos do estado, ligado diretamente à administração e à tomada de

\footnotetext{
${ }^{139}$ Revista do Instituto Histórico e Geográfico de São Paulo. São Paulo, vol. 10, 1905.

140 Decreto $\mathrm{n}^{\circ}$ 4.917, de 03 de março de 1931, transformou a Secretaria dos Negócios do Interior em Secretaria da Educação e Saúde Pública. Assinado por João Alberto Lins de Barros (Interventor Federal), o decreto $\mathrm{n}^{\circ} 4.917$, em seu art. $2^{\circ}$, definia que tudo aquilo que não estivesse expresso como atribuição da nova Secretaria passaria para a jurisdição da Secretaria da Justiça. Assim, pelo art. $17^{\circ}$ a Repartição tornava-se oficialmente parte da Secretaria da Justiça.

${ }^{141}$ Tratou-se do período entre a publicação dos decretos $n^{\circ} 4.917$, de 03 de março de 1931, e o decreto $\mathrm{n}^{\circ}$ 5.243 , de 27 de outubro do mesmo ano. A correção veio com o segundo decreto, assinado pelo também Interventor Federal Laudo Ferreira de Camargo.

${ }^{142}$ Vale lembrar que o DASP (Departamento Administrativo do Serviço Público) foi criado em 1938 por meio do decreto-lei $\mathrm{n}^{\circ}$ 579, diretamente subordinado ao Presidente da República, com o intuito de profissionalizar a carreira de servidor público. Por meio dele os cargos do funcionalismo passaram a ser escolhidos de acordo com critérios técnicos, e não por indicações políticas.

${ }^{143}$ Tratou-se do decreto $\mathrm{n}^{\circ} 9.036$, de 14 de março de 1938. Um novo decreto, o de $\mathrm{n}^{\circ} 9.285$, de 01 de julho de 1938, assinado pelo Interventor Federal Adhemar Pereira de Barros, em seu art. $1^{\circ}$ renomeava a Repartição, que passou a chamar-se Departamento do Arquivo do Estado, dotando-lhe de três seções (uma administrativa, outra histórica e uma última de expediente e contabilidade) e 24 funcionários.
} 
decisões, o recém criado Departamento de Arquivo selava seu futuro desde o nascedouro. Na medida em que abriu mão de qualquer função administrativa relevante, sendo relegado a um segundo plano na estrutura pública, o Departamento adquiriu um verdadeiro caráter de depósito (muitas vezes de "papéis velhos"), que persiste até o séc. XXI, servindo muito menos à administração e tomadas de decisões do que para pesquisadores, diletantes ou acadêmicos, interessados em tomar contato com esse material ${ }^{144}$.

Ao que consta, após inúmeras mudanças de endereço, uma ordem de "despejo" fez com que todo o acervo fosse dividido e transportado para três novos depósitos na cidade de São Paulo. A operação de mudança contou com o auxílio do trabalho "técnico especializado" fornecido pelos funcionários da Divisão de Parques e Jardins da Prefeitura. Um desses novos depósitos utilizados situava-se no piso térreo do prédio do então Departamento de Ordem Política e Social (DOPS), no largo $G^{\text {al }}$ Osório $^{145}$. Ao que parece, os outros dois endereços eram alugados pelo estado, ficando um na r. Visconde do Rio Branco, 237 e outro na r. dos Timbiras, $361^{146}$.

Devido à necessidade de espaço, tanto para o Arquivo como para os serviços policiais, uma penúltima mudança ocorreu em 1953, entre os meses de fevereiro e maio, dessa vez com o auxílio de homens da Força Pública. Nesse momento o Estado responsabilizou-se por alugar um antigo prédio na rua Dona Antonia de Queiroz, 183, no bairro de Cerqueira César, na capital, que comportasse todo o acervo, bem como seus setores técnicos. Foram ocupadas as dependências da

\footnotetext{
${ }^{144}$ A criação de um Departamento Central de Estatística responsável por sistematizar informações capazes de subsidiar eventuais ações do poder público, representou uma verdadeira ruptura na trajetória da instituição vinculada, desde sua criação, com as atividades inerentes à administração. O surgimento do Departamento de Arquivo, retirando dele qualquer vínculo direto com as tomadas de decisão, significou relega-lo à condição subalterna que persistiu no Arquivo por muito tempo, assumindo sua condição "histórico-cultural" e eventualmente probatória. Vale salientar que, a partir desse momento, o binômio acumulação documental/ função institucional, comum a toda instituição arquivística, foi reorientado pelo próprio estado, deixando de ser um efetivo instrumento de governo.

${ }^{145}$ Esse edifício fora projetado pelo escritório do arquiteto paulista Francisco de Paula Ramos de Azevedo para servir, originalmente, como depósito e escritório da Companhia Estrada de Ferro Sorocabana. Inaugurado em 1914, foi reformado para receber o DOPS em 1939.

${ }_{146}$ Para maiores referências vale a consulta às notas de empenho existentes no acervo do AESP. Departamento de Arquivo do Estado (notas de empenho), E 11853, 23 e 26/ 01/ 1940, e E 11873.
} 
então fábrica de tapetes Santa Helena. Nesse momento, o Arquivo continuava sob a jurisdição da Secretaria dos Negócios da Educação e Saúde Pública. Visando a preservação dos originais, todo o acervo foi colocado em "latas de alumínio, hermeticamente fechadas, após serem, de maneira conveniente, dedetizados"147.

A última mudança física do acervo ocorreu de fato em 1998, quando todo o Arquivo foi realocado em um prédio no bairro de Santana, também na capital paulista. Seria a primeira vez em toda sua trajetória que o Arquivo do Estado contaria com dependências próprias.

Mesmo com as novas instalações não contando com um projeto arquitetônico ideal, o risco oriundo da mudança do acervo de um prédio para outro diminuíram muito. A questão que passou a ser colocada seria como preservar uma grande massa documental, composta basicamente por suporte em papel, altamente susceptíveis quando expostos a elevados teores de umidade, ficando acomodada a apenas 500 metros do maior rio urbano da capital.

Apesar das inúmeras mudanças de prédio, bem como das transformações ocorridas em relação ao conceito de patrimônio e de tudo aquilo que deveria ser preservado e divulgado em termos documentais nos últimos 114 anos, o Arquivo do Estado sempre teve no Instituto Histórico e Geográfico de São Paulo uma instituição irmã, com atribuições e envolvimentos políticos muito semelhantes. Mesmo sendo uma instituição privada local, suas atribuições confundiam-se com a de outras instituições congêneres espalhadas pelo país, mesmo que públicas. Esse foi o caso da Repartição de Estatística e Arquivo, com quem o Instituto manteve profundas afinidades, pelo menos durante seus 10 primeiros anos, em uma clara demonstração de simbiose entre aquilo que poderia ser chamado de interesse público e as ambições e necessidades privadas.

\footnotetext{
${ }^{147}$ AESP. Relatório Departamento de Arquivo do Estado de São Paulo. São Paulo, AESP, 1953, p. 02.
} 


\section{3- O IHGSP e a figura do bandeirante}

Se por um lado, coube à Repartição de Estatística e Arquivo produzir, conservar, organizar e disponibilizar a documentação acumulada pelo poder público de São Paulo, coube, pelo menos durante seus primeiros anos de existência, a instituições parceiras como o Instituto Histórico e Geográfico de São Paulo produzir análises acerca de um passado paulista, capaz de dar vazão aos anseios de uma elite tradicional ${ }^{148}$, até então "deixada de lado" por uma historiografia produzida no Rio de Janeiro imperial, sob uma vertente unificadora.

Após o Golpe da Maioridade (1840) que colocou no poder D. Pedro II, com apenas 14 anos de idade, as forças políticas em vigência passaram a fomentar o desenvolvimento de instituições como o Instituto Histórico e Geográfico Brasileiro (IHGB), a Academia de Belas-Artes e o Colégio Pedro II como espaços privilegiados para a construção de uma imagem de nação. Assim, o discurso produzido por estas instituições tornava-se cada vez mais afinado com o do poder central $^{149}$. A construção de mecanismos identitários voltava-se para o aspecto do nacional, em detrimento dos elementos locais, elaborando-se um repertório simbólico capaz de "unificar" o Brasil em torno de um poder político que emanava da cidade do Rio de Janeiro.

No caso de São Paulo, a imagem construída a cerca de seu passado repleto de glórias foi fruto da ação direta de historiadores alocados em instituições responsáveis pela elaboração oficial de uma determinada memória. Diferente de outros estados, como Minas Gerais ou mesmo parte dos estados da região Nordeste, onde a participação de ensaístas e romancistas foi muito mais contundente na construção de sua representação de passado, em São Paulo coube ao trabalho de historiadores o destaque dado ao "símbolo maior da identidade regional" que foi o

\footnotetext{
${ }^{148}$ É importante salientar que muitos daqueles que contribuíram com a Revista do IHGSP também garantiram presença atuante junto ao Arquivo do Estado e suas publicações. Para maiores informações, ver Capítulo II.

${ }_{149}$ MATTOS, Claudia V. de. "Imagem e palavra". In: OLIVEIRA, Cecília Helena de Salles; MATTOS, Claudia Valladão de (org.). O brado do Ipiranga. São Paulo, Edusp/ Museu Paulista, 1999.
} 
bandeirante, especialmente diante o "jogo de aproximação e distanciamento com a figura do jesuíta" ${ }^{\prime 50}$.

Como aponta Danilo Ferretti, a figura do bandeirante nunca contou com um sentido unívoco, "sendo representado de forma diferente pelos diversos historiadores que dele se apropriaram"151.

Ao analisar a trajetória dessa figura na historiografia nacional e paulista, Ferretti discutiu a inexistência, nas primeiras décadas no séc. XIX, de um espírito de identidade brasileira, especialmente constatável na medida em que boa parte dos colonos aqui presentes se sentia muito mais como portugueses residentes na América do que brasileiros, ou quando muito, alimentavam um espírito identitário regionalista. Como Sérgio Buarque de Holanda apontou, independência e unidade seriam dois termos com significados bem precisos e distintos naquele momento, predominando "entre os portugueses da América o sentimento de identidade

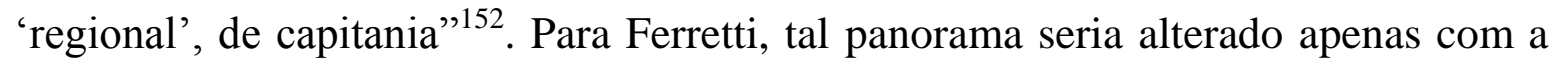
chegada da Família Real em 1808, e mesmo assim, diante de um restrito grupo de intelectuais.

No caso paulista, os primeiros autores a louvarem o seu passado glorioso, defendendo o papel desempenhado por sua elite, foram Frei Gaspar da Madre de Deus e Pedro Taques de Almeida Paes Leme ${ }^{153}$.

"Os paulistas que participaram das entradas para o sertão eram louvados pela liderança na preação de índios, na busca de minas de ouro e pedras preciosas para o rei e pelo combate aos estrangeiros e escravos rebeldes. Além de lembrar o inegável serviço e fidelidade à coroa prestado pelos paulistas antigos (...) Seus esforços foram todos no sentido de frisar a fidalguia dos troncos mais antigos de paulistas mediante o destaque dado às exigências para o pertencimento ao grupo dos Homens Bons, que representava exatamente o ápice da sociedade

\footnotetext{
${ }^{150}$ FERRETTI, Danilo José Zioni. A construção da paulistanidade. Identidade, historiografia e política em São Paulo (1856-1930). São Paulo, Tese de Doutorado defendida no Departamento de História da Faculdade de Filosofia, Letras e Ciências Humanas da Universidade de São Paulo, 2004, p. III.

${ }^{151}$ Idem, p. X.

${ }^{152}$ Idem, p. 2.

${ }^{153}$ Para maiores informações acerca desses autores e suas obras, vale a leitura da Revista do IHGSP e dos Documentos interessantes para a história e costumes de São Paulo. Ver Capítulo II.
} 
colonial. Assim, os antigos paulistas eram descritos como bravos militares, grandes senhores de terras e arcos, além de donos de inegável atestado de pureza de sangue exigido pelo tempo. Este último tópico é de especial importância, na medida em que ao frisar o sangue puramente europeu dos antigos paulistas, Pedro Taques negava a miscigenação com sangue índio que estava na raiz da maioria dos clãs vicentinos ou, quando impossível fazê-lo, condenava o relapso paulista promotor da mestiçagem" $" 154$.

Além disso, para os dois autores, um dos objetivos maiores de suas obras era o de rebater as acusações proferidas pela Igreja, em especial por seus representantes jesuítas. Para esses religiosos, as expedições sertanistas organizadas pelos paulistas não passavam de ações criminosas responsáveis, entre outras coisas, pela destruição de missões jesuíticas como as de Tapes e Guairá, ambas na região sul da colônia ${ }^{155}$.

$\mathrm{Na}$ visão da historiadora Kátia Abud, existiria na produção historiográfica referente à construção da imagem do bandeirante um desejo de valorização dos antigos moradores da capitania, em detrimento de um novo grupo, cada vez mais numeroso, oriundo de ondas imigratórias vindas da Metrópole. Fixando-se no comércio, esses novos moradores passaram a disputar espaço com membros das famílias tradicionais de São Paulo, especialmente em relação a cargos públicos. Nesse sentido, a historiografia do setecentos tornou-se "um relato do valor e das ações gloriosas de uma aristocracia tradicional da capitania a serviço da grandeza da Coroa Portuguesa", sendo Portugal a nação e São Paulo a pátria ${ }^{156}$.

Contudo, a consolidação dessa elite não se reverteu em uma produção historiográfica capaz de legitimar suas ações políticas, diferentemente do que ocorreria com os republicanos da virada do séc. XIX para o XX. Um dos possíveis motivos para a falta de um discurso identitário regional talvez fosse decorrência de um "acanhamento do ambiente cultural da São Paulo imperial", sendo que todos

\footnotetext{
${ }^{154}$ FERRETTI, D. A construção da paulistanidade. Op. Cit., p. 4.

${ }^{155}$ Muitos documentos referentes a esta questão foram selecionados pela Repartição de Estatística e Arquivo e publicados em diversos volumes da série Documentos interessantes. Para maiores informações, ver Capítulo II.

${ }^{156}$ FERRETTI, D. A construção da paulistanidade. Op. Cit., p. 5.
} 
aqueles com pretensões literárias e acadêmicas acabavam sendo atraídos para o Rio de Janeiro, "verdadeira capital da cultura letrada nacional"

"A própria Academia de Direito, normalmente tomada como foco de produção cultural paulista, dificilmente pode ser tomada como representante dos interesses regionais, uma vez que, segundo Antônio Cândido, não mantinha uma relação orgânica com a sociedade paulista, sendo antes uma congregação a ela justaposta. Estudantes e professores, na sua maioria originados de outras províncias do Império, como que formavam um círculo à parte da sociedade paulista e que somente secundariamente influiu na elaboração de um discurso identitário regional. ${ }^{158,}$

Nesse cenário, a tendência predominante na produção historiográfica brasileira pautava-se nos interesses e visão de mundo reproduzidos pelo Instituto Histórico e Geográfico Brasileiro (IHGB) criado em 1838, voltando suas atenções à ancestralidade indígena e colonial brasileira, e colocando a figura do jesuíta como o grande exemplar de um passado colonial grandioso, responsáveis, na visão de Ricardo Gumbleton Daunt, por tirar São Paulo das trevas. Assim, coube ao Marquês de Pombal a pecha de grande "articulador" da decadência paulista.

Agindo em duas frentes, o IHGB pretendeu elaborar uma identidade nacional capaz de sobrepujar os diferentes elementos regionais, além de reeducá-los em nome de uma adequação subalternizada frente a uma identidade nacional recém criada. A intenção dessa agremiação seria a de "elaborar uma história una da nação e na escrita de histórias provinciais submetidas ao padrão de nacionalidade monárquico" ${ }^{159}$. Em última instância, essa associação refletia o papel centralizador exercido pela Corte no que dizia respeito à produção cultural brasileira. Tal tendência pode ser percebida pelos objetivos traçados no interior do IHGB desde sua criação, qual sejam, o de concentrar em seus arquivos na Corte "os principais documentos e fontes referentes à história do país”, bem como incentivar a produção

\footnotetext{
${ }^{157}$ Idem, p. 14.

158 Ibidem.

${ }^{159}$ Idem, p. 27.
} 
de monografias referentes às histórias provinciais, tornando-se um espaço privilegiado para o contato das elites intelectuais regionais ${ }^{160}$.

Um forte debate instalou-se no interior do Instituto mediante a tendência de se escrever uma história do Brasil a partir de um viés unificador. A grande crítica vinha da impossibilidade de se produzir uma história geral, especialmente devido à falta de estudos específicos. Uma saída conciliadora veio com o trabalho premiado de Karl Friedrich Von Martius ${ }^{161}$ que levava em conta o local, mas sem cair no exclusivismo do regional, considerando-se apenas os elementos que fossem efetivamente comuns a todas as províncias, numa clara demonstração de uma História do Brasil eminentemente política, capaz de fornecer subsídios às mais diferentes medidas adotadas pelo poder imperial.

Tratava- se de permitir a construção de uma historiografia capaz de dar vazão ao espírito centralizador, costurando-se uma história nacional calcada em um espírito de pertencimento a um passado comum e glorioso. Assim, a história antes de servir como suporte a um discurso regional, tornava-se um instrumento de inserção de cada uma das províncias no cenário nacional centralizado. A "alma da pátria" estaria intimamente ligada ao elemento indígena e seu "pai", na figura do Monarca, representaria a soberania nacional ${ }^{162}$.

Toda essa produção norteou-se por meio de uma tradição intelectual ilustrada, própria do séc. XIX, amparando-se em uma visão de desenvolvimento histórico linear e progressista, passando pelos mais diferentes estágios. Em uma visão evolucionista, sua produção apontava os diferentes graus de civilização atingidos pelos habitantes da América, desde seu estágio nativo. Nesse sentido,

\footnotetext{
${ }^{160}$ Idem, p. 28- 29. Vale lembrar que o IHGB promoveu expedições pelo país com o intuito de recolher arquivos e documentos em diversas províncias, enviando representantes às mais diferentes localidade do país apenas com essa finalidade. Apesar de todas as diferenças existentes entre o Instituto brasileiro e o paulista, tal atitude de acúmulo de documentos, fosse por recolhimento ou doação, também foi adotada em São Paulo, na expectativa de se preservar a história local.

${ }^{161}$ Trata-se do trabalho intitulado "Como se deve escrever a história do Brasil", publicado originalmente em 1844, e reeditado in: $O$ estado do direito entre autóctones do Brasil. Belo Horizonte/ São Paulo, Itatiaia/ Edusp, 1980.

162 MAGNOLI, Demétrio. O corpo da pátria. Imaginação geográfica e política externa no Brasil (18081912). São Paulo, Editora da UNESP/ Moderna, 1977. Cf. FERRETTI, D. A construção da paulistanidade. Op. Cit.
} 
tornava-se premente a constituição de uma imagem positivada do indígena, degradado apenas após o contato colonizador promovido pelo branco europeu. Tal visão contou com profundas críticas, especialmente aquelas produzidas por Von Martius, que via no nativo um degenerado.

Com isso, o colonizador paulista, apresador de índios e opositor dos jesuítas, passou a ser visto como o grande inimigo da história nacional. Apesar do receio quanto à sua força reacionária, esses religiosos foram vistos pela historiografia produzida pelo IHGB como verdadeiros heróis civilizadores. Para José Joaquim Machado de Oliveira, seguidor da corrente indigenista, Martim Afonso de Sousa deveria ser louvado por ter preservado o elemento nativo do contato com o português, proibindo-o de se fixar no planalto paulista ${ }^{163}$. Contudo, era condenado por ter "permitido a introdução da semente do mal em São Paulo, representada pela instituição da escravidão indígena"164. Se para Machado de Oliveira a figura do bandeirante era mostrada sem o fausto e brilho próprio das obras de Saint Hilaire e Pedro Taques, o mameluco era ainda pior retratado por ser considerado embrutecido e possuidor de uma origem nefasta, fruto da miscigenação. Para o autor, a supressão do bandeirismo teria sido uma demonstração da regeneração desse grupo, que nada de negativo teria transmitido a seus descendentes.

Outro ramo do IHGB valorizava as expedições paulistas pelo interior, especialmente naquilo que concernia a seu aspecto de conquista de território. Tal produção encarregava-se de fornecer subsídios históricos aos tratados diplomáticos de fronteiras e limites junto aos países vizinhos. Para os membros dessa corrente, seriam os bandeirantes os verdadeiros responsáveis pela construção da unidade territorial da colônia em nome da Coroa. Nas palavras de José Feliciano Fernandes

\footnotetext{
${ }^{163}$ Sobre a produção desse autor, vale a leitura de: OLIVEIRA, José Joaquim Machado de. Quadro histórico da província de São Paulo até o ano de 1822. São Paulo, Governo do Estado, 1978; e OLIVEIRA, José Joaquim Machado de. Geografia da província de São Paulo adaptada à lição das escolas e oferecida à Assembléia Legislativa provincial. São Paulo, Tipografia Imparcial, 1862.

${ }^{164}$ MAGNOLI, D. O corpo da pátria. Op. Cit., p. 69.
} 
Pinheiro, o visconde de São Leopoldo, "a história da província de São Paulo será também a história geral do Brasil”165.

O único autor ligado ao IHGB que realmente se dedicou a escrever uma história una do Brasil foi Francisco Adolfo Varnhagen, opondo-se à matriz identitária indigenista. Para Ferretti, o autor propunha a imagem de um bandeirante apresador de índios bravos, adquirindo o direito de uso por seus serviços.

Percebendo que a adoção de "métodos brandos não eram eficazes e, colocando a razão de Estado acima de qualquer outro valor, partiam para o apresamento direto, possibilitando o crescimento da colônia" ${ }^{\prime 166}$.

Assim, os ataques promovidos às comunidades indígenas eram tratados como a vitória da civilização sobre a barbárie, trazendo uma solução à falta de mão-deobra na colônia.

Vale salientar que a posição indigenista ganhou força a partir de 1840, na mesma época em que o antilusitanismo perdia relevância. O próprio imperador D. Pedro II apoiou fortemente a intelectualidade nacional, construindo "uma imagem e uma história para o país" ${ }^{\prime 67}$. Desde a independência, o sentimento nacionalita ganhava força, especialmente na busca de um passado histórico próprio. Foi nesse cenário que exaltação da natureza passou a ocorrer (assim como já havia sido feito a própria Europa), sendo utilizada como ferramenta política para ofuscar as profundas crises sociais, financeiras e econômicas por que passava o país. Para muitos a escolha da figura do indígena como símbolo de brasilidade ocorrera devido a uma total "falta" de opção, na medida em que os portugueses não poderiam ser escolhidos, pois o Brasil acabara de conquistar sua independência (ressentimentos

\footnotetext{
${ }^{165}$ A frase deixaria clara a sobreposição do espírito regional ao nacional, colocando São Paulo como epicentro da nacionalidade. PINHEIRO, José Feliciano Fernandes. Anais da província de São Paulo. Rio de Janeiro, Imprensa Nacional, 1946, p. 31. Cf. FERRETTI, D. A construção da paulistanidade. Op. Cit., p. 72.

${ }^{166}$ FERRETTI, D. A construção da paulistanidade. Op. Cit., pp. 78- 9.

${ }^{167}$ ROWLAND, Robert. "Patriotismo, povo e ódio aos portugueses: notas sobre a construção da identidade nacional no Brasil independente”. In: JANCSÓ, István. Brasil: formação do estado e da nação. São Paulo, Hucitec, 2003.
} 
ainda eram significativos) e muito menos os negros, na medida em que sua condição amparava-se na negação de sua humanidade.

A partir da crise do império que marcou as décadas de 1870 e 1880, parcela significativa da elite paulista, descontente com a centralização fiscal existente, acabou por fortalecer o movimento republicano, haja vista ser este um dos motivos apontados pelo grupo como empecilho para o avanço da cafeicultura na região. $\mathrm{Na}$ prática, São Paulo pagaria mais em impostos ao governo central do que via revertido sob a forma de investimentos. Nas palavras de Alberto Salles, São Paulo tornara-se uma "feitoria imperial" 168 .

A posição da intelectualidade brasileira ligada ao IHGB pode parecer, num primeiro momento, algo desvinculado dos interesses primeiros desse trabalho. Contudo, vale salientar que os paulistas, em grande medida favoráveis ao movimento republicano, articularam-se em torno do Instituto Histórico e Geográfico de São Paulo (IHGSP), declarando franca oposição ao seu co-irmão carioca. Com isso, coube aos membros do Instituto paulista elaborar sua versão sobre a grandiosidade dos ancestrais de São Paulo, expressando-a por meio das páginas de sua Revista, amparadas pela documentação fidedigna disponibilizada pela Repartição de Arquivo. Assim, o federalismo tornava-se a grande bandeira de seu projeto modernizador, fortemente influenciado pelas teorias positivista e darwinista. Para esse grupo, o paradigma construído pelos Estados Unidos demonstrava-se "prova maior da superioridade da forma republicana sobre a monárquica, representada pelo 'atraso' do Império brasileiro" ${ }^{\text {169 }}$. Por meio da produção do IHGSP o povo paulista passou a ser representado da mesma forma que os estadunidenses, dotados de qualidades emancipadoras e empreendedoras ${ }^{170}$.

\footnotetext{
${ }^{168}$ SALLES, Alberto. A pátria paulista. Brasília, Editora da UnB, 1983, p. 45.

${ }^{169}$ FERRETTI, D. A construção da paulistanidade. Op. Cit., pp. 135- 6.

${ }^{170}$ Não foi por acaso a confecção da bandeira de São Paulo sob a forma das treze listras. Criada pelo jornalista republicano Júlio Ribeiro em 1888, logo após a abolição da escravatura, tratou-se de uma "imitação" da bandeira dos Estados Unidos. Concebida originalmente para servir de pavilhão nacional, passou a ser utilizada como símbolo do Partido Republicano Paulista (PRP) e, após a República, foi adotada como símbolo de São Paulo.
} 
Fundado em 1894, por ação de membros da elite paulista, o IHGSP passou a produzir um discurso identitário próprio, reflexo de um processo de desenvolvimento econômico por que passava a província desde a década de 1860 advindo do avanço das zonas cafeeiras. Vale lembrar que tal mecanismo alterou significativamente a relação de São Paulo com o restante do país ${ }^{171}$. Assim, iniciouse uma campanha no sentido de fortalecer o discurso regional sobre o nacional, pensando São Paulo como elemento construtor do Brasil, legitimando a hegemonia do estado sobre o restante do país.

Se uma região é sempre parte de um todo, as tentativas de construção de identidades regionais conviveriam com formas diversas de identidade. No caso paulista, o próprio IHGSP tentou de diversas maneiras impor sua versão ao restante das unidades federativas.

De acordo com Roberto Machado Carvalho, o chamamento para a instalação do Instituto paulista foi realizado por meio de nota publicada no jornal $O$ Estado de São Paulo de 01 de novembro de 1894, convidando "todos os homens de letras" a comparecer na velha academia de Direito a fim de criar o Instituto Histórico Paulista $^{172}$.

Conforme registrado em suas atas, transcritas no primeiro volume da Revista do IHGSP, ainda na primeira reunião, Antonio de Toledo Piza, então Diretor da Repartição de Estatística e Arquivo, fora aclamado como Secretário do Instituto, assim como todo o restante da diretoria interina ${ }^{173}$. Uma quarta reunião ocorreria em uma sala da Escola Normal (23 de dezembro do mesmo ano), encarregando Domingos Jaguaribe, Garcia Redondo e Toledo Piza por formarem uma comissão responsável por compilar e apresentar um Estatuto "ordenado e corrigido" após

\footnotetext{
${ }^{171}$ Vale salientar que nesse cenário um sem número de gabinetes de leitura, escolas e jornais foram abertos por todo o interior, atendendo a uma demanda oriunda do crescimento populacional. Tais iniciativas permitiram o surgimento de uma lógica cultural paulista, principalmente vinculada ao movimento republicano.

172 CARVALHO, Roberto Machado. "A fundação do IHGSP- os idealizadores e a sessão inaugural". In: Revista do Instituto Histórico e Geográfico de São Paulo. São Paulo, vol. 88, 1993.

${ }^{173}$ De acordo com Roberto Machado Carvalho, nessa mesma sessão o então Presidente da República, Sr. Prudente de Morais, foi eleito presidente honorário da instituição. Idem.
} 
todas as discussões feitas entre os associados. Apesar de seu envolvimento, Toledo Piza não fez parte da primeira diretoria eleita, cabendo a ele a liderança da comissão responsável pela redação de sua Revista, cargo que ocupou até sua morte em 1905.

$\mathrm{Na}$ opinião de seus próprios fundadores, a finalidade do Instituto seria: "promover os meios de estudar tantos documentos com os quais se pode vir a conhecer a origem dos mais importantes feitos dos nossos antepassados, ou esclarecer noções errôneas sobre fatos que merecem ser devidamente conhecidos" ${ }^{\prime 174}$.

Para o imaginário político republicano produzido em São Paulo, a figura do paulista antigo passou a ocupar posição de destaque, legitimando sua identificação com a causa republicana. Nesse processo, associaram-se os temas da liberdade primitiva dos paulistas com a identidade regional e o mito de origem com o Partido Republicano Paulista (PRP). De acordo com Ferretti,

"ao contrário de republicanos jacobinos e positivistas cariocas- que investiram em Tiradentes e na figura feminina da República, que apontam para uma visão unitária do país- os paulistas, em função da centralidade que conferiam à questão federalista, colocaram a temática regional no centro de sua pregação política"175.

Visto como uma exceção em relação ao restante do país, essa diferença legitimaria a posição de liderança política e econômica adotada por boa parte da elite de São Paulo. Muitos dos autores da época lançaram mão de um discurso histórico-científico amparado por uma proposta de determinismo geográfico e racial, tão comum em um momento em que a escola metódica se projetava com muita força

\footnotetext{
${ }^{174}$ DEBES, Célio. "A revista do Instituto Histórico e Geográfico de São Paulo e a pesquisa histórica”. In: Revista do Instituto Histórico e Geográfico de São Paulo. São Paulo, vol. 88, 1993.

175 FERRETTI, D. A construção da paulistanidade. Op. Cit., p. 153. Para José Murilo de Carvalho, a manutenção da unidade territorial brasileira após a independência somente fora possível mediante a projeção de um grupo da elite cuja formação ideológica o diferenciava das elites regionais. Na República, tal elemento ganharia maior projeção, agora com uma unidade construída mediante arranjos institucionais possíveis surgidos dos embates e negociações ocorridos entre os diferentes grupos elitistas, especialmente aqueles ligados ao café. Sobre esta questão lave a leitura de: CARVALHO, José Murilo de. A construção da ordem. A elite política imperial. Brasília, UnB, 1981.
} 
nos meios intelectuais brasileiros, criando em São Paulo uma suposta tradição de modernidade, e valendo-se dela como impulso simbólico ${ }^{176}$.

Os trabalhos elaborados sob esse tema, entre as décadas de 1870 e 1880, contavam com pouquíssima pesquisa empírica, ressalva feita à produção de Manuel Eufrásio de Azevedo Marques, conforme destacou Ferretti, que "igualava" tanto jesuítas como colonos paulistas como aqueles que lutavam pela defesa de seus interesses ${ }^{177}$. Nessa mesma época tornaram-se comuns as obras de cunho propagandístico e de divulgação, como foi o caso de A província de São Paulo, trabalho estatístico, histórico e noticioso, escrito por Joaquim Floriano de Godoy, especialmente produzido para ser distribuído na exposição internacional da Filadélfia $(1876)^{178}$.

Nessa ocasião, São Paulo carecia de historiadores capazes de criar uma nova historiografia que não estivesse pautada em "crônicas de monarcas e generais", mas que voltasse suas atenções ao "povo e se amparasse nos modernos métodos

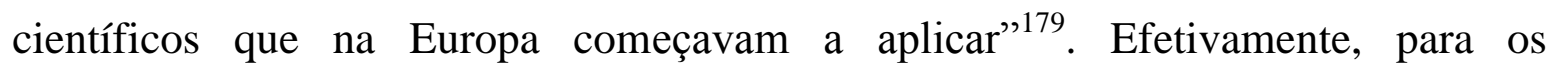
idealizadores do IHGSP “a história de São Paulo é a própria história do Brasil”. Assim, o objetivo do Instituto era conhecer, por meio de documentos

\footnotetext{
${ }^{176}$ Esse é o caso de autores como Martim Francisco e Alberto Salles que, entre outras coisas, defendiam até mesmo a separação de São Paulo em relação ao restante do país por ser esta uma região dotada de clima ameno, um povo predominantemente branco e dotado, desde a origem, de espírito autônomo e independente. Foi assim que a figura do bandeirante passou a gozar de grande prestígio e símbolo da identidade local, tornando-se verdadeiros ancestrais da elite cafeeira. FERRETTI, D. A construção da paulistanidade. Op. Cit, pp. 187- 92.

${ }^{177}$ Seu livro, Apontamentos históricos, geográficos, estatísticos e noticiosos da província de São Paulo, de 1879, contava com privilegiada pesquisa em documentos oficiais, sendo o autor um funcionário da Secretaria da Província, órgão detentor do principal acervo de então.

178 De acordo com Heloísa Barbuy, tais exposições surgiram em 1851, na cidade de Londres (Great Exhibitionof the Workof Industry of All National) e perduraram até 1915 (Exposição Internacional de São Francisco), servindo para divulgar modelos burgueses considerados indiscutíveis. Não deixava de ser um produto oferecido às massas, gozando de grande publicidade. Comumente seus projetos estavam ligados à mentalidade científica classificatória e enciclopédica, com seus produtos oriundos do "gênio humano". De acordo com Bernadette Bensaude-Vincent e Anne Rasmussen, as exposições seriam tidas como universais pois convite à participação era extensivo a todas as nações do mundo, além de apresentar um apanhado de todas as atividades humanas em um formato enciclopédico tridimensional e servir para propagação, pelo progresso, das normas da Revolução Francesa. Vale lembrar que estas exposições ultrapassaram seu objetivo pedagógico inicial, num processo dinâmico de "produção, consumo e reciclagem" (p. 17), atuando como um grande panorama de representação de mundo, visto em seu todo e de uma só vez. BARBUY, Heloísa. A exposição universal de 1889 em Paris. São Paulo, Loyola, 1999.

${ }^{179}$ FERRETTI, D. A construção da paulistanidade. Op. Cit., p. 196.
} 
"a origem dos mais importantes feitos dos nossos antepassados, ou esclarecer noções errôneas sobre fatos que merecem ser devidamente esclarecidos", devendo aperfeiçoar o trabalho de pesquisa até que "nossa história seja a fiel interprete dos acontecimentos, e o ensinamento útil dos patriotas" 180 .

Tais transformações somente encontraram um terreno favorável para sua efetivação mediante o advento da República, em especial a partir da Constituição de 1891, quando o lema positivista de "ordem por princípio, amor por meio e progresso por fim" foi adotado junto ao poder central. Se por um lado a ordem foi mantida mediante o uso da força, o clima de instabilidade pôs em risco o progresso econômico almejado por membros da elite. Os chamados restauracionistas, intelectuais desejosos pelo retorno da família de Bragança ao poder, concentravamse no eixo Rio de Janeiro- São Paulo, em boa medida ocupando posições importantes no IHGB e demais instituições culturais e administrativas do país.

Uma mudança efetiva veio a reboque da eleição à Presidência da República do advogado paulista, nascido em Itu, Prudente José de Morais Barros, em 1894. Membro da oligarquia cafeeira, Prudente de Morais foi eleito em um processo que contou com a participação de apenas $6 \%$ da população (recebeu aproximadamente 270 mil votos), não significando uma vitória inconteste imposta pelos perrepistas aos demais grupos políticos em voga no Brasil, nem tampouco representou o sufocamento, da noite para o dia, dos descontentamentos e distúrbios em todo o país. Vale salientar que tal "transformação" ocorreu apenas mediante a implantação de um acordo informal elaborado em conjunto entre os membros das elites locais, esparramadas por todo o país, e o governo federal. Esse acordo ficou conhecido por Política dos Governadores, quando da presidência do também paulista Manoel Ferraz de Campos Salles (1898), estabelecendo-se mecanismos de apoio mútuo entre essas elites e a Presidência da República. Assim, os paulistas detiveram o poder político central por aproximadamente uma década (1894- 1905), mas

\footnotetext{
${ }^{180}$ Revista do Instituto Histórico e Geográfico de São Paulo. São Paulo, vol. 1, 1895, pp. 10- 11.
} 
preservaram o controle da estrutura econômica nacional até por volta dos anos 1930, tendo o café como seu carro chefe.

$\mathrm{Na}$ última década do séc. XIX a zona cafeeira foi ampliada consideravelmente por todo o oeste paulista, resultando na abertura de mais de 40 novos municípios ${ }^{181}$. Fazendas eram abertas pelo interior, e com elas toda a modernidade subjacente era divulgada. Com isso, São Paulo viveu um momento impar na história brasileira, especialmente no tocante à ampliação da malha ferroviária em todo o estado, além do surto de crescimento urbano em alguns importantes centros regionais. Vale salientar que, se a primeira estrada-de-ferro inaugurada em território paulista foi a Santos- Jundiaí, construída com recursos públicos e tendo por objetivo abrir São Paulo para o mundo, ela era, na prática, um prolongamento da navegação a vapor. A partir dessa primeira iniciativa, o estado foi recortado por ferrovias construídas com dinheiro exclusivamente privado, muito dele procedente do café. Um dos motivos que talvez ajude a explicar a preocupação do governo estadual com investimentos em infra-estrutura, especialmente a partir de 1892, advenha do fato de a Constituição federal de 1891 permitir às unidades da federação o direito de usufruir dos impostos oriundos de exportações ${ }^{182}$. Assim, os incentivos tornaram-se cada vez maiores, especialmente quanto à ampliação das áreas cafeeiras pelo estado, transformado as ferrovias em verdadeiros mecanismos de "cata café", seguindo o rastro das zonas pioneiras e sem nenhum planejamento prévio $^{183}$. Nessa ocasião, o Brasil chegou a produzir $75 \%$ de todo o café consumido no mundo, sendo que grande parte dele saia por Santos ${ }^{184}$.

\footnotetext{
${ }^{181}$ SILVA, Lígia Osório. Terras devolutas e latifúndio. Os efeitos da lei de 1850. Campinas, Unicamp, 1996.

${ }^{182}$ Se a abertura de ferrovias ficou a cargo da iniciativa privada, coube ao poder público paulista investir especialmente na modernização do porto de Santos. CARONE, E. A evolução industrial de São Paulo. Op. Cit.

${ }^{183}$ MATOS, Odilon Nogueira de. Café e ferrovias. São Paulo, Alfa-Ômega, 1974.

184 De acordo com Thomas Holloway, mesmo com as crises financeiras mundiais decorrentes de superprodução, que ocasionavam a queda no preço do produto, a elite brasileira continuava ganhando dinheiro, especialmente por meio do câmbio, levando a cabo mecanismos de desvalorização da moeda nacional, gerando inflação e comprometendo aspectos econômicos internos. HOLLOWAY, T. H. Imigrantes para o café. Rio de Janeiro, Paz e Terra, 1984.
} 
Em decorrência de toda essa efervescência, desde 1885 a elite letrada de São Paulo vinha se articulando com o intuito de criar uma instituição capaz de agregar as mais diferentes tendências, inclusive políticas. Assim, fruto de uma atitude absolutamente pouco produtiva, foi posta em funcionamento a Sociedade dos Homens de Letras de São Paulo. Na prática, nenhuma iniciativa semelhante a essa obteve algum resultado positivo antes do período republicano.

Contudo, em 1894, quando o IHGSP foi criado, contava com inegável "apoio" do governo estadual paulista. A "trindade fundadora", composta por Toledo Piza, Domingos Nogueira Jaguaribe e Estevão Leão Bourroul, tinha nos dois primeiros funcionários ativos da Secretaria do Interior (Toledo Piza era Diretor da Repartição de Estatística e Jaguaribe Diretor em exercício do Liceu de Artes e Ofícios) ${ }^{185}$.

Tendo como Secretário o Sr. Cesário Motta Jr, colocado à frente da Secretaria em 1892, pelo então Presidente de Estado Bernardino de Campos, foi posta em vigor uma verdadeira "reforma cultural republicana", conforme apontou Ana Maria de Alencar Alves ${ }^{186}$, dotando o estado de um conjunto de instituições encarregadas pela produção e reprodução de novos saberes, concorrendo diretamente com as orientações emanadas do Rio de Janeiro, fazendo de São Paulo não mais um mero pólo cultural paralelo.

Ao citar Joseph Love, Ferretti apontou que tal atitude diferenciava profundamente a orientação intelectual da elite paulista em relação às demais, "mais inclinadas a se concentrarem na Capital Federal"187. A partir dessa época o estado passou a promover uma profunda reforma educacional, em seus diferentes níveis, mediante a abertura de grupos escolares pelo interior, a criação do Ginásio do

\footnotetext{
${ }^{185}$ Em relação a essa "trindade", Danilo Ferretti aponta para a diversidade de opiniões entre eles, o que significaria, na prática, no acolhimento das mais diferentes tendências políticas existentes no seio da elite paulista, mas empenhada na construção de um passado sólido e coeso. Se Bourroul representava a ala católico-monarquista, tanto Toledo Piza quanto Jaguaribe eram legítimos representantes dos segmentos republicanos, estando o segundo ligado a setores territorialistas, dedicando-se ao tema da ocupação do sertão oeste do estado.

${ }^{186}$ ALVES, A. M. de A. O Ipiranga apropriado. Op. Cit., p. 75.

${ }^{187}$ FERRETTI, D. A construção da paulistanidade. Op. Cit., p, 202.
} 
Estado e a reformulação da Escola Normal, instalada em um edifício na Praça da República. Além disso, na mesma época foram inaugurados o Museu Paulista e a Escola Politécnica, em uma clara demonstração de confluência dos interesses privados da elite e o poder público. Vale salientar que Cesário Motta era o legítimo representante de um espírito republicano interessado em "criar uma instituição que desse suporte e contornos mais precisos à identidade regional paulista". Foi nesse contexto que surgiu o IHGSP que, de acordo com Antônio Celso Ferreira, apesar de ser uma entidade privada, contava com a subvenção de recursos públicos, chegando a representar até $44 \%$ de seu orçamento anual ${ }^{188}$.

Inicialmente, o discurso histórico produzido pela instituição distanciava-se muito pouco do padrão criado pelo próprio IHGB, tendo como eixos centrais questões como o campo político e etnográfico, além de um forte vínculo com o poder instituído. Não se pode perder de vista que, se por um lado mostrava-se necessária a produção de um novo saber histórico amparado não mais em anedotas ou lugares comuns, mas sim, em métodos científicos, embasados na documentação oficial recolhida, avaliada e preservada, por outro, o apoio dado à criação do IHGSP não bastava para que tal idéia pudesse ser levada a cabo. Assim, nesse mesmo contexto, o governo responsabilizou-se por recolher, triar e disponibilizar ao público interessado (especialmente historiadores ligados ao IHGSP) parte significativa da documentação produzida pelo estado ou sob sua guarda, para que novos trabalhos historiográficos pudessem aparecer, trazendo em seu bojo a grandeza da capital bandeirante ${ }^{189}$. Não é demais lembrar que a instituição pública criada para esse fim, a Repartição de Estatística e Arquivo, tinha como seu Diretor o Sr. Antônio de Toledo Piza, a mesma pessoa que participou do chamamento dos membros da elite

\footnotetext{
${ }^{188}$ Para Ferretti, certa autonomia financeira do Instituto pode ser percebida apenas entre os anos de 1913- 27 e 1931- 6. Ver: FERREIRA, Antônio Celso. A epopéia paulista: imaginação literária e invenção histórica (1870-1940). Tese de Livre Docência defendida no Departamento de História da UNESP de Assis, 1999, p. 73.

${ }^{189}$ Toda essa produção serviu, em termos, para a consolidação da imagem de São Paulo como território de exceção no processo colonizador (autonomia), além de buscar no passado colonial as raízes da hegemonia política conquistada pelo estado (uso da tradição como mecanismo de estabilização).
} 
paulista para que participassem da criação do IHGSP, tornando-se membro atuante também nessa instituição.

Como destacou Ferretti,

o IHGSP "além de procurar legitimar o novo governo republicano, ele seria uma instituição voltada a consolidar um discurso identitário regional, que já vinha sendo de legitimação da ordem descentralizada e federalista" ${ }^{\prime 190}$.

Vale salientar que nas primeiras décadas do novo regime, inúmeros Institutos semelhantes foram criados em todo o país, em uma clara demonstração da federalização das forças políticas, tornando-se "espaços privilegiados de sociabilidade das elites regionais, agora alçadas pela política dos governadores a

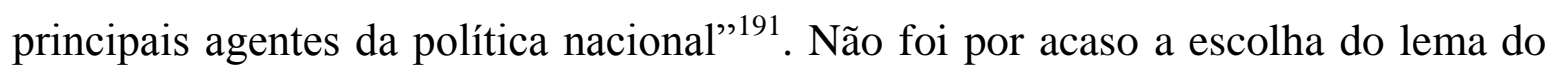
Instituto: “A história de São Paulo será a própria história do Brasil".

"Como ressaltou Antônio Celso Ferreira, os autores do IHGSP investiram na louvação de figuras históricas paulistas, identificadas como pioneiras na construção do conjunto da nacionalidade brasileira. Assim, o período colonial teria o bandeirante como figura de destaque na criação da base territorial nacional; a independência teria sido obra dos irmãos Andrada e de câmaras municipais como a de Itu, estudadas por Antônio de Toledo Piza e a unidade nacional consagrada pelo Segundo Império, teria sido fruto não de D. Pedro II, figura cultuada pelo IHGB, mas do regente paulista Diogo Feijó e, por fim, os republicanos paulistas Campos Sales e Prudente de Morais seriam apresentados como os verdadeiros artífices do regime republicano.

(...) [O discurso acabou assumindo certa coerência sendo que] dos primórdios da colônia até a era republicana, São Paulo e seus habitantes teriam como missão histórica a construção da nação brasileira, mediante a difusão da liberdade e a definição e povoamento do vasto território nacional, fonte das riquezas do país. ${ }^{192,}$

\footnotetext{
${ }^{190}$ FERRETTI, D. A construção da paulistanidade. Op. Cit., p. 205.

191 Ibidem.

${ }^{192}$ Idem, p. 206.
} 
Frente a tantas questões díspares, porém complementares, o discurso produzido pelo IHGSP não poderia ter sido homogêneo. Analisando a produção historiográfica decorrente da criação do IHGSP e seus primeiros 10 anos de existência, Danilo Ferretti apontou para a existência de três correntes internas que privilegiavam aspectos diferentes do passado paulista, dando vazão a cada um dos setores representados pela "trindade fundadora". Seriam elas: a corrente monárquico-católica, a corrente liberal republicana e a territorialista. $\mathrm{Na}$ prática $\mathrm{o}$ Instituto acabou assumindo a responsabilidade de institucionalizar as representações do passado paulista mediante a verificação científica promovida pela análise e crítica das fontes documentais, reafirmando a imagem positiva e laudatória do bandeirante ${ }^{193}$.

Diante de uma "tradição" republicana que ainda não se sustentava, o IHGSP atuou no sentido de legitimá-la nos campos da liberdade e soberania popular, desqualificando o regime monárquico. Assim, esse caráter de proximidade de São Paulo com o "grande irmão do norte" foi constantemente reafirmado nas páginas da Revista do Instituto, mediante a publicação de artigos amparados em pesquisas documentais, efetivadas principalmente junto ao acervo da Repartição de Estatística e Arquivo. Esse foi o caso da produção de Antônio de Toledo Piza, vendo no período colonial o bom tempo original de São Paulo, sua "idade de ouro", marcada pela "ausência do poder despótico do governo colonial" e percebendo a republicanidade paulista já no séc. XVII. Em sua perspectiva, a fusão da figura do paulista com o espírito republicano deu-se no bandeirante sem, contudo, elevar o tom quando o assunto eram os jesuítas e sua expulsão do solo português.

Ao que tudo indica, uma das principais preocupações do IHGSP era estabelecer a unidade da elite mediante a adoção de uma postura conciliadora e cooptadora diante as divergências, em especial o grupo católico, colocando a proclamação da República como o evento que poderia restabelecer os vínculos existentes, desde a origem, entre o paulista nato e a democracia, sendo capaz de

\footnotetext{
${ }^{193}$ Idem, p. 212.
} 
fazer com que São Paulo reencontrasse sua antiga e legítima vocação, perdida mediante adoção de políticas metropolitanas mais severas a partir de 1721 e a nomeação de Rodrigo César de Menezes para o cargo de Capitão-Mor da capitania $^{194}$. Além disso, teria sido com o Morgado de Matheus o momento em que Portugal retomara o controle político efetivo de parte de seu território colonial impondo, como afirmou Toledo Piza em seu artigo, O militarismo em São Paulo, de "medidas restritivas da liberdade individual e do direito de locomoção e a exação vigorosa e vexatória de pesados impostos", sendo este o momento da "decadência intelectual e moral da capitania" ${ }^{, 195}$.

Outra importante contribuição recebida pelo IHGSP veio diretamente das hostes da Comissão Geográfica Geológica de São Paulo, montada a pedido do Presidente da Província João Alfredo, em 1886, com a intenção de realizar um levantamento das potencialidades naturais da província. Foi daí que saíram Orville Derby e Teodoro Sampaio, respectivamente Diretor e primeiro ajudante da Comissão ${ }^{196}$.

Para muitos dos membros da elite paulista, esses "desbravadores" modernos fariam as vezes dos bandeirantes de outrora, responsáveis por uma nova conquista do sertão paulista, só que desta vez amparada na ciência.

Em termos historiográficos, Derby dedicou-se em fazer, a partir de um grande levantamento documental, a definição de nomes, datas e rotas de expedições bandeirantes pelo interior, construindo um verdadeiro panorama de integração nacional, em boa medida amparada em documentos existentes no acervo da Repartição de Estatística. Destacou-se também no estabelecimento das divisas entre São Paulo e Minas Gerais, fazendo em nível regional o que a historiografia do IGHB fez em nível nacional.

\footnotetext{
${ }^{194}$ Idem, p, 216- 7.

195 Idem, p. 221.

196 De acordo com Ferretti, a Comissão nada sofreu com a proclamação da República, visto ser a questão territorialista um dos principais interesses dos políticos republicanos. Idem, pp. 227- 8 .
} 
A diferença de tom entre essas correntes deu-se na medida em que, para um grupo, a visão republicana se amparava na atuação das instituições políticas, enquanto para outra corrente isso ocorreria mais pela geografia da região e na relação do homem com o meio.

Se por um lado Derby dedicou-se aos estudos sobre as questões espaciais e geográficas que envolviam São Paulo, para Teodoro Sampaio a "posição do Brasil apresentava uma grande e quase insuperável desvantagem: a sua tropicalidade". Este seria um dos principais obstáculos ao progresso brasileiro, sendo a questão climática a responsável pela criação de "um meio adverso à ação do europeu". Assim, a história do Brasil poderia ser resumida em uma constante luta do homem contra o meio (a vitória do homem resultaria na conquista de territórios). Nesse contexto, a figura dos cafeicultores paulistas poderia ser associada à figura do bandeirante desbravador e civilizador do sertão oeste. Para Sampaio, tanto jesuítas como bandeirantes estariam unidos em torno de um ideal comum, qual seja, o de ocupação do sertão, unindo o imaginário da elite política paulista em torno da conciliação do jesuíta e do bandeirante como agentes civilizadores. No limite, para Sampaio, a mestiçagem tornara-se um elemento positivo, permitindo ao colono aclimatar-se ao ambiente americano, forjando um "espírito de ação, independência e coragem incomparáveis".

A saída de Sampaio do IHGSP em 1903, a morte de Toledo Piza e a destituição de Derby do cargo de Diretor da Comissão Geológica em 1905, representaram importantes desfalques para o Instituto no final de sua primeira década de existência. Nas palavras de Danilo Ferretti,

"Fechava-se a primeira fase do IHGSP, que deixou consolidado os alicerces da historiografia regional paulista, desenvolvida nos anos 20. O bandeirante, outrora desprezado pela historiografia monárquico-indianista, acabou se tornando a figura histórica central da produção do Instituto paulista e símbolo maior dos atributos da identidade modernizante e progressista que a elite regional se auto atribuía. No interior do IHGSP ele tinha consolidado o seu processo de reabilitação, iniciada pela dupla fonte da historiografia territorialista 
renovada de Capistrano de Abreu e da contra história republicana, passando de anti-herói nacional, ao posto de herói civilizador dos bárbaros sertões brasileiros e construtor do corpo da pátria"197.

Apesar das perdas ocorridas no cenário intelectual paulista não restam dúvidas quanto à importância da preservação e publicação de fontes documentais iniciadas por algumas dessas personalidades, tanto no IHGSP como na própria Repartição de Estatística e Arquivo, disponibilizando ao público conjuntos de documentos especialmente referentes ao período colonial ${ }^{198}$. Uma das principais iniciativas desse processo veio com a publicação dos Documentos interessantes para a história e costumes de São Paulo, em 1894, alvo de análise do próximo capítulo.

\footnotetext{
${ }^{197}$ Idem, p. 238.

198 Vale a lembrança de que o grande responsável pela publicação dos Documentos interessantes foi seu diretor, Antônio de Toledo Piza, o mesmo que participou da fundação do IHGSP.
} 


\section{Capítulo 2}

\section{O Arquivo do Estado e seus Documentos interessantes para a história e costumes de São Paulo}

\section{1- A "política" de publicações do Arquivo do Estado}

Durante um longo período foi prática corrente manter os arquivos fechados, longe do olhar público, por representarem reservatórios de um status político e econômico, além de atuarem como verdadeiros arsenais de provas de direitos, principalmente quanto a guerras de sucessão nobiliárquicas. A grande preocupação dos responsáveis por esse material era garantir o segredo de documentos considerados úteis ao poder, lançando mão deles sempre que necessário.

O panorama começou a ser alterado de maneira mais intensa com o advento do Estado Moderno e a instalação de estruturas burocráticas necessárias à sua administração. No séc. XVI, o rei Felipe II da Espanha centralizou seus documentos no palácio de Simancas, enquanto o Pontificado reorganizava seus arquivos no Vaticano visando exercer com maior eficiência seu poder universal ${ }^{199}$.

Mas foi durante o séc. XIX que os debates acerca da preservação do patrimônio histórico e artístico, em especial pelo interesse suscitado por colecionadores, tornaram-se mais intensos. O elevado volume de destruição, fosse por conflitos ou descaso, trouxe a reboque o aumento no número de amantes de tudo aquilo que pudesse ser considerado "raro" e exótico. Museus consolidaram sua imagem, construída desde o séc. XVIII, de instituições de "conservação material das pinturas, esculturas e objetos de arte antigos", preparando o caminho para a preservação de monumentos arquitetônicos. Durante a Revolução Francesa, essas

\footnotetext{
${ }^{199}$ Na opinião de Heloísa Liberalli Bellotto existiria um forte vínculo entre os arquivos e o direito, pois os primeiros representariam verdadeiros "armazéns" legislativos, atuando como celeiros informativos para o Estado. Com o advento da Revolução Francesa, estas instituições tornar-se-iam também arsenais para os cidadãos em litígio. Para maiores informações ver: BELLOTTO, Heloísa Liberalli. Arquivística: objetos, princípios e rumos. São Paulo, Arq-SP, 2002.
} 
instituições passaram a ter função de instruir a nação, transferindo bens móveis para locais definitivos e abertos ao público. Com isso, muitos objetos simplesmente foram sacados de seus contextos originais, distanciando-se das idéias que lhes davam vida ${ }^{200}$.

Ainda nessa época, o debate acerca da preservação e disponibilização de séries documentais ganhou força ${ }^{201}$, especialmente devido à corrente acadêmica conhecida por Escola Metódica. Os historiadores passaram a utilizar séries documentais homogêneas e coerentes, deixando de lado o uso de documentos únicos, retirados de seus contextos. Foi quando surgiram os arquivos nacionais ${ }^{202} \mathrm{e}$ numerosos textos foram transcritos em grandes coleções (Monumenta historiae) capazes de sistematizar tudo aquilo que era considerado básico para a história de uma nação ${ }^{203}$. Vale lembrar que toda essa preocupação, na modernidade, remonta ainda ao séc. XVIII quando a centralização e organização dos arquivos adquiriram certa relevância, em decorrência do espírito cientificista das luzes, bem como das demandas administrativas, especialmente relacionadas ao Império Português.

No caso brasileiro, a criação do Arquivo Nacional no segundo quartel do séc. XIX seguiu os mesmos moldes de uma tradição portuguesa, fosse pelo apego à genealogia administrativa, fosse pelo patrimônio que conservava em seu acervo ${ }^{204}$. Contrariamente à tradição espanhola, durante o período colonial não foi constituído no Brasil nenhuma instituição de guarda de acervo documental centralizada. Na

\footnotetext{
${ }^{200}$ Sobre essa questão vale a leitura da obra de CHOAY, Françoise. A alegoria do patrimônio. São Paulo, Estação Liberdade/ Editora da Unesp, 2001, p.62.

${ }^{201}$ Vale lembrar que durante o período conhecido por Grande Medo (agosto de 1789), inúmeros documentos cartoriais foram queimados pela população francesa, imaginando-se que com isso seria superada a questão da propriedade da nobreza sobre a terra.

202 No caso brasileiro, um Arquivo Imperial, apesar de previsto desde a Constituição de 1824, foi criado apenas em 1838, durante a regência de Pedro de Araújo Lima. Foi nesse mesmo ano que surgiu o Instituto Histórico e Geográfico Brasileiro (IHGB), fundado nos mesmos moldes do Instituto Histórico parisiense, de 1834.

${ }^{203}$ WITTER, José Sebastião. Arquivo e história. O Arquivo do Estado de São Paulo na administração e na história. Tese de Livre Docência apresentada na FFLCH da Universidade de São Paulo, 1981.

${ }^{204}$ ARQUIVO NACIONAL. O Arquivo Nacional: 1838- 2004. Rio de Janeiro, Arquivo Nacional, 2004, p. 19. http://www.portalan.arquivonacional.gov.br/Media/Catalogo\%20Institucional.pdf (acessado em 22 de junho de 2009).
} 
visão de Antonio Cândido, as transformações no cenário intelectual brasileiro, pensadas desde a $2^{\mathrm{a}}$ metade do séc. XVIII, ocorreriam apenas quando

"imprensa, periódicos, escolas superiores, debate intelectual, grandes obras públicas, contato livre com o mundo (numa palavra, a promoção das luzes) assinalam o reinado americano de D. João VI, obrigado a criar na Colônia pontos de apoio para o funcionamento das instituições"205.

Por ocasião da transposição da Corte portuguesa para terras de além mar, o Real Arquivo da Torre do Tombo, designado como arquivo régio, não chegou a ser transladado para a América, ficando a salvo da fragmentação (ao contrário do que ocorrera com os arquivos de diversas Secretarias de Estado).

Uma vez posto em funcionamento, ações sistemáticas no sentido de estabelecer políticas de preservação dos documentos, bem como divulgá-los, foram empreendidas pelo Arquivo Nacional brasileiro mediante publicação de fac-símiles de documentos. O séc. XIX foi marcado por ações conjuntas do Museu Nacional, Biblioteca Nacional e IHGB no sentido de enriquecerem seus acervos por meio de captação de obras, coleções e documentos, fossem em outras localidades brasileiras, fosse na Europa, inclusive pressionando o governo imperial para promover pesquisas junto à Torre do Tombo. Na impossibilidade de se obterem os originais, eram providenciadas cópias, no intuito de sanar a falta de informações com relação à história nacional, bem como limites com outros países e o direito canônico. Em 1852 Antônio Gonçalves Dias teve a missão de "coligir documentos em bibliotecas e arquivos de mosteiros e repartições públicas, em diversas províncias do Norte, reunindo, especialmente, aqueles que pelo decreto de 1838 deveriam ser recolhidos ao Arquivo Público" ${ }^{206}$. Contudo, foi apenas no séc. XX, mais precisamente em

${ }^{205}$ CÂNDIDO, Antonio. Formação da literatura brasileira: 1750- 1836. Belo Horizonte, Itatiaia, 1975, p. 227.

${ }^{206}$ O mesmo Gonçalves Dias foi enviado para a Europa, em 1856, para recolher informações existentes em arquivos portugueses e espanhóis, mas desta vez para o IHGB. ARQUIVO NACIONAL. O Arquivo Nacional. Op. Cit., p. 26. 
1927, em parceria com a Biblioteca Nacional, que teve início a publicação de uma série intitulada Documentos históricos ${ }^{207}$.

Seguindo uma linha muito semelhante, em São Paulo foi criado em 1892 a Repartição de Estatística e do Arquivo do Estado. Se em boa parte de suas seções existia a preocupação com a sistematização, produção e análise de dados quantitativos/estatísticos que melhor pudessem nortear as ações do poder público paulista, em seu arquivo eram depositados documentos que pudessem servir de subsídio ao trabalho de historiadores, especialmente aqueles ligados ao Instituto Histórico e Geográfico de São Paulo (IHGSP).

Na Revista deste Instituto, capitaneada pelo próprio Toledo Piza desde sua criação, diversas personalidades encontraram espaço para deixarem registradas suas opiniões acerca da grandeza paulista, fosse ela política, econômica, social ou geológica. Sua intenção era permitir o estudo do maior volume possível de documentos para, assim, conhecer as origens dos "mais importantes feitos dos nossos antepassados, ou esclarecer noções errôneas sobre fatos que merecem ser devidamente conhecidos"208. A continuidade dos trabalhos deveria ser mantida até que "nossa história seja a fiel interprete dos acontecimentos"209. Nessa linha, o primeiro volume acolheu artigos de Orville Derby ("A denominação 'serra da Mantiqueira'"), Domingos Jaguaribe ("Origens republicanas do Brasil") e o discurso de João Monteiro em homenagem à independência dos Estados Unidos. Autores como Teodoro Sampaio, Derby, Monteiro e o próprio Toledo Piza mostraram-se figuras constantes nas páginas da Revista ao longo de seus primeiros anos.

Algumas obras completas foram inicialmente publicadas aí. Este foi o caso do texto produzido por Washington Luís ("Capitania de São Paulo"), mais tarde publicada sob a forma de livro. O mesmo autor também publicou artigos sobre a

\footnotetext{
207 Vale salientar que os trabalhos técnicos visando a elaboração de instrumentos de pesquisa, especialmente índices, tiveram início ainda em 1860. Tratavam-se das relações dos Códices e Chancelaria-mor, cartas régias, provisões, alvarás e avisos (entre os anos de 1662 e 1771), Tribunal da Mesa da Consciência e Ordens, e a correspondência da Corte com os Vice-reis no Brasil. Idem.

${ }^{208}$ Revista do Instituto Histórico e Geográfico de São Paulo. São Paulo, vol. 1, 1895, p. I.

${ }^{209}$ Idem, p. II.
} 
"verdadeira" identidade de Antonio Raposo, "perdido" entre 5 homônimos. Nas palavras de Célio Debes,

"ambas essas contribuições são produtos das pesquisas arquivais que, entre 1900 e 1903, o futuro Presidente de São Paulo e da República levou a efeito nos Arquivos Municipais e do Estado" ${ }^{210}$.

Um grande volume de documentos foi reproduzido e publicado, especialmente de maneira transcrita. Contudo, na mesma década em que o Arquivo Nacional iniciava a publicação de sua série de documentos históricos, o Arquivo do Estado já acumulava um grande volume de publicações congêneres. Coube à direção de Antonio de Toledo Piza iniciar as publicações do Arquivo, fosse por meio da reprodução de documentos inéditos ou de outros já conhecidos pelo público pesquisador, mas considerados importantes.

Iniciada ainda no final do séc. XIX, a iniciativa de reproduzir documentos considerados relevantes para a história de São Paulo teve continuidade ao longo de todo o séc. XX. Em muitos casos a autorização para uma nova série de publicações vinha diretamente da presidência do Estado. Já em 13 de maio de 1894, Toledo Piza enviava um ofício ao Secretário do Interior (Cesário Motta Jr.) solicitando dinheiro para a publicação de 1.000 exemplares do "folheto intitulado A Bernarda de Francisco Ignácio" ${ }^{211}$, considerado relevante à história pátria e paulista.

Em outra ocasião, o mesmo Diretor enviou ao Sr. Alfredo Pujol (então Secretário do Interior), um ofício encaminhando originais do Repertório da legislação provincial (1876- 89) para análise e possível impressão. Tratava-se da continuação de uma publicação congênere, organizada por João Carlos Da Silva Telles, abarcando o período de 1835 a $1875^{212}$.

\footnotetext{
${ }^{210}$ DEBES, Célio. "A revista do Instituto Histórico e Geográfico de São Paulo e a pesquisa histórica". In: Revista do Instituto Histórico e Geográfico de São Paulo. São Paulo, vol. 88, 1993, p. 64.

${ }^{211}$ Acervo AESP. Repartição de Estatística e Arquivo (correspondências), E 01434 (folha 192).

${ }^{212}$ Acervo AESP. Repartição de Estatística e Arquivo (correspondências), E 01438 (folha 62, de 06 de agosto de 1897).
} 
Seguindo a mesma linha, é possível tomar como exemplo a publicação de uma série denominada Inventários e testamentos. Iniciada sua edição em 1920, sob influência das publicações das Atas e do Registro Geral da Câmara Municipal de São Paulo, feita durante a administração de Washington Luis, quando prefeito da capital, sua intenção primeira era preservar a informação contida nessa documentação da ação deletéria da umidade e agentes biológicos nocivos, como traças. Recolhida havia poucos anos ao acervo do Arquivo, a documentação encontrava-se incompleta e desfalcada ${ }^{213}$, contendo apenas os inventários, e mesmo assim não todos, visto que a documentação depositada em muitos cartórios já havia desaparecido. O próprio Washington Luis deliberou e autorizou a impressão dos autos, por se tratar de documentação capaz de subsidiar a reconstrução do "estado social da época" e as "particularidades do início da formação paulista"214.

Em seu primeiro volume, referente ao período de 1548 a 1603, foram reproduzidos os documentos do $1^{\circ}$ Cartório de Órfãos da capital. A preservação deste material mostrava-se importante visto que por meio dos registros de avaliação de bens móveis e imóveis (terras, escravos, gado, ferramentas, roupas, objetos domésticos, pequenas bibliotecas) seria possível explicitar a existência de um conjunto de relações comerciais baseadas na troca de mercadorias, além de jogar luz em aspectos da vida social, econômica, costumes e "ocupações cotidianas dos paulistas de outrora" ${ }^{215}$. Ainda hoje, esse material se apresenta como uma das poucas fontes documentais capazes de permitir a reconstituição do modo de vida de um determinado grupo social e econômico, em especial dos primeiros moradores de São Paulo, cujo distanciamento temporal mostra-se mais severo quanto à preservação de vestígios do passado. Muitas declarações registradas nesses documentos decorreram de informações recebidas ainda enquanto um grupo de homens encontrava-se em expedição pelo sertão, sendo oficializadas quando do

\footnotetext{
${ }^{213}$ AESP. Inventários e testamentos. São Paulo, Departamento de Arquivo, 1920, vol. I, p. VI.

${ }^{214}$ AMARAL, Antônio Barreto do. O departamento de arquivo do estado e sua história. São Paulo, DAESP, 1974, p. 66.

${ }^{215}$ AESP. Inventários e testamentos. Op. Cit., p. III.
} 
regresso do grupo à capital paulista. Tais informações constariam de inventários "provisórios", feitos ainda no sertão, e depois "legalizados" por ocasião do término da expedição. Aparentemente, aproveitava-se tudo o que era possível, inclusive os leilões dos bens feitos pelo comandante da bandeira ${ }^{216}$. A publicação desse material foi mantida pelo Arquivo até o ano de 1999, totalizando 47 volumes.

Outra publicação que durante muito tempo ocupou lugar de destaque, tanto no cenário intelectual paulista como quanto aos esforços técnicos do próprio Arquivo, foram as Sesmarias. Iniciada em 1921, também por determinação de Washington Luis, a transcrição desse material se estendeu por 6 volumes $(1944)^{217}$ registrando as cartas de doação de terras efetuadas por diferentes capitães-mores, entre os anos de 1602 e $1821^{218}$. Aparentemente, o objetivo primeiro dessa publicação era o de dar vazão à intensa demanda, por parte dos pesquisadores, a informações precisas sobre a procedência, posse e demarcação dessas terras. Os dois primeiros volumes referiam-se a "dois grossos alfarrábios, que foram cuidadosamente restaurados e copiados" ${ }^{, 219}$. Como desde 1720 esse material deixara de ser registrado em livro próprio, passando a compor o segmento do acervo denominado "Sesmarias, Patentes e Provisões", muito desse material havia sido publicado nos Documentos interessantes de maneira esparsa. A retomada da publicação desse material pelo Arquivo teve o interesse de dar fim à empreitada, publicando as cartas "avulsas" de forma sistemática e em ordem cronológica, mesmo que por vezes já tivessem vindo a público. Na opinião de João Lellis Vieira, Diretor do Arquivo em 1944, tratava-se de oferecer maior facilidade aos consulentes visto que

\footnotetext{
${ }^{216}$ Uma análise mais detalhada desse material permitiria reconstruir uma expedição bandeirante, bem como o caminho percorrido.

${ }_{217}^{217}$ No decorrer do processo, constatou-se que algumas transcrições haviam sido omitidas, fosse por descuido ou incapacidade de transcrição devido ao péssimo estado de conservação. Além disso, outros registros foram encontrados posteriormente, por terem sido arquivados de maneira equivocada. Com isso, foi necessária a edição de volumes com o subtítulo de Bis. Esse foi o caso dos volumes II e III. AMARAL, A. B. do. $O$ departamento de arquivo. Op. Cit., p. 69- 70.

${ }^{218}$ Parte desse material foi publicado pelo Instituto Histórico e Geográfico de São Paulo (IHGSP) devido a existência de contrato do Estado com esse órgão privado em 1937.

${ }^{219}$ AESP. Sesmarias. São Paulo, IHGSP, 1937, vol. III, p. 5.
} 
“a vulgarização por este meio dos 'Códices' possuídos pelo Arquivo melhor atenderia o objetivo a que se propõe, isto é, dar na íntegra, a parte essencial, devidamente copiada, e aqui entregue ás investigações dos que se interessam pelo estudo de um passado que tanto nos significa, pelo valor dos seus nobres espíritos, pelo acentuado patriotismo dos seus propósitos e pelo fulcro de glória que nos foi legado.

Assim, aqui tem os homens de hoje, páginas magníficas para as pesquisas dos séculos, em cujas notas, informações, manuscritos e documentos, poderão haurir os mais fulgurantes ensinamentos das épocas pretéritas" 220 .

Durante o Estado Novo, mais precisamente em 1939, o acervo do Arquivo foi sistematicamente registrado em seu Catálogo da seção histórica do Departamento do Arquivo do Estado de São Paulo ${ }^{221}$. Tratou-se de iniciativa promovida pelo Arquivo Nacional após o desmembramento, em São Paulo, da antiga Repartição de Estatística e Arquivo. Pelo decreto $n^{\circ}$ 9.036, de 14 de março de 1938, criava-se o Departamento de Arquivo, encarregado por recolher, guardar e disponibilizar toda a documentação produzida pelo governo estadual em sua instância executiva, enquanto caberia ao recém criado Departamento Estadual de Estatística (decreto ${ }^{\circ}$ 9.330, de 15 de julho de 1938) parte das antigas funções da Repartição. O novo Arquivo, agora como uma repartição pública independente, seria o local para onde recorreriam tanto a administração como o público pesquisador interessado na busca de material guardado para "se instruírem sobre fatos passados que influem sobre o

\footnotetext{
${ }^{220}$ AESP. Repertório de sesmarias. São Paulo, AESP, 1994, p. 07 (edição fac-similar).

${ }^{221}$ É importante salientar não ter sido esta a primeira iniciativa de produzir um instrumento de pesquisa que fosse capaz de abarcar a totalidade do acervo. Ferramentas de acesso vinham sendo confeccionadas desde o início do séc. XX. Talvez o primeiro exemplo disso no Arquivo tenha sido a publicação do Histórico do archivo público de São Paulo; acompanhado da relação dos cidadãos que governaram a província e o estado, em 1908. Além de traçar um o quadro "biográfico" da instituição, e trazer uma relação com os nomes de cada um dos governantes de São Paulo, esta obra ainda registrou, individualmente, todos os volumes encadernados de documentos existentes em seu acervo, fazendo alusão a eventuais expurgos ocorridos durante o período imperial, e que nunca tinham sido oficial e devidamente registrados, e indicar o material publicado na série Documentos interessantes. Aparentemente, foi na época dessa publicação que toda a documentação do acervo fora separada seguindo-se um critério cronológico, recebendo notação TC, para Tempo Colonial, e TI, para Tempo Imperial.
} 
presente" 222 . Pautando-se na opinião do antigo Diretor Antonio de Toledo Piza, o novo Arquivo seria um órgão administrativo de grande valor para o governo.

Sendo assim, em 1942 teve início a publicação intitulada Boletim do Departamento do Arquivo do Estado de São Paulo. Contando com 16 volumes apresentava características peculiares apesar de ser seu objetivo o mesmo de outras publicações congêneres mantidas pela instituição, qual fosse, o de salvaguardar os documentos da "ação destruidora das traças e também do tempo",223. Para Lellis Vieira, a intenção da publicação seria a de "divulgar uma documentação que muito servirá para fonte de locubrações e estudos" ${ }^{224}$. Entre seus volumes I e VIII foram editados apenas documentos transcritos cujos originais se encontravam no próprio acervo da instituição, em especial referentes aos períodos colonial e Império. Tratava-se de cópia de material armazenado sob o rótulo "Tempo Colonial", organizado em 97 maços. Apesar da semelhança, esse documentos não foram publicados nos Documentos interessantes pois poderiam parecer deslocados "se não no interesse ou utilidade (...) pelo menos na cronologia"225, visto que na ocasião, estavam sendo publicadas nos Documentos interessantes apenas correspondências de capitães-generais ${ }^{226}$.

Para Lellis Vieira o Arquivo teria material preparado para publicar 100 livros, "trabalho executado com patriotismo, visando salvar das traças e do tempo, as jóias seculares de papéis que falam alto de nosso passado e de nossa tradição", visto que

"divulgar épocas, homens, fatos e episódios constantes do riquíssimo documentário do Arquivo, é o objetivo desta

\footnotetext{
${ }^{222}$ AESP. Catálogo da seção histórica do Departamento do Arquivo do Estado de São Paulo. Rio de Janeiro, Oficina Gráfica do Arquivo Nacional, 1939, p. 05.

223 AESP. Boletim do Departamento do Arquivo do Estado de São Paulo. São Paulo, Departamento de Arquivo, 1942, vol. I, p. 06. Para maiores informações sobre os títulos de cada um dos volumes da coleção, ver Anexo II.

${ }^{224}$ Idem, 1942, vol. II, p. 04.

${ }^{225}$ Idem, 1952, vol. IX, p. 03.

${ }^{226}$ Nos anos 1990 a série Boletim do Arquivo voltou ser editada, dessa vez com a intenção de divulgar debates acerca do campo arquivístico e das ações do próprio Arquivo. Contudo, em alguns volumes, essa característica foi sendo perdida em nome da publicação de textos de análise historiográfica. Esse foi o caso do Boletim do Arquivo, vol. IV, $\mathrm{n}^{\circ}$ 2, de 2002.
} 
diretoria para que os futuros estudiosos possam focalizar a grandeza de nosso passado",227.

Imbuído do mesmo espírito de Toledo Piza, o então Diretor, além de se responsabilizar pela transcrição e publicação de documentos do acervo do Arquivo, também escrevia artigos em periódicos da capital, em especial o Correio Paulistano, sendo que alguns deles eram transcrições e comentários sobre documentos existentes no próprio acervo do Arquivo. Assim, em texto de abertura do volume VI do Boletim, Vieira corrigia em 5 dias a duração do governo paulista de João Carlos Augusto de Oeynhausen (assumindo o cargo em 1819, teria saído destituído do poder em 24 de agosto e não 19 de agosto de 1822$)^{228}$. Afinal de contas, de acordo com suas palavras, a "história, é isso mesmo. Através de investigações positivas e documentais é que se podem lançar afirmativas categóricas",229.

Nessa ocasião São Paulo continuava sendo visto como a "locomotiva do país", fosse em termos econômicos ou sociais, cabendo um papel de destaque a seus grandes homens. Para Lellis Vieira,

"São Paulo, cuja formação étnica do século XVII se entrosava nas veias mais puras da nobreza européia, tinha mesmo de ser o que é- o 'Non ducor duco' das prioridades e primazias comerciais, agrícolas e industriais. Despido de orgulho e vaidade, trabalhando sempre para o bem comum, Piratininga marca a sua primeira etapa de fidalguia e desprendimento, quando, Amador Bueno, em 1640 proclamado Rei de São Paulo, ali mesmo nas portadas do velho mosteiro de S. Bento, recusou tal título porque, paulista, leal, franco, sincero, honesto, íntegro, puro e portador de uma tradição nobilitante, não poderia trair a $\mathrm{D}$. João IV, reconhecendo-o monarca de Portugal. Amador Bueno é um tipo representativo da 'Raça de Gigantes' de que fala Alfredo Ellis o mestre ilustre da História Paulista. Daí para cá, uma incontável galeria de homens geniais enriquecem a terra dos Taques, com seus extraordinários atributos de civismo e dedicação ao berço em que nasceram.

\footnotetext{
${ }^{227}$ AESP. Boletim do Departamento. Op. Cit. 1943, vol. III, p. 03.

${ }^{228}$ Apesar de ser ele um militar e político português de carreira (foi Governador das capitanias do Pará, Ceará, Mato Grosso e São Paulo), apoiou a Independência do Brasil apesar de fazer oposição a José Bonifácio de Andrada e seu grupo (daí sua demissão do cargo de Governador de São Paulo).

${ }^{229}$ AESP. Boletim. Op. Cit. 1946, vol. VI, p. 08.
} 
Esse 'Boletim', como aliás os 112 volumes publicados por esse Departamento, constitui mais um galardão impresso das eras que se foram e deixaram na luminosidade dos seus rastros, sulcos imortais, indeléveis, característicos e típicos, e eternos do povo piratiningano" ${ }^{\text {230 }}$.

Mesmo com toda essa "grandeza", o Boletim teve sua edição suspensa. Após um período de quatro anos a publicação passou por uma mudança em seu perfil editorial, assumindo a forma que o próprio nome indicava. Com isso, artigos passaram a ser produzidos especialmente para esta publicação, deixando a transcrição de documentos a cargo de uma nova série iniciada pelo Arquivo sob o título Documentos avulsos. Em seu volume IX, de 1952, o Boletim trazia informações sobre o andamento dos seus serviços, estudos, ensaios e espaço para comunicados sobre a própria instituição ${ }^{231}$. Em "Breve história do Arquivo", o então Diretor Ubirajara Dolácio Mendes, mostrava que o Departamento, vinculado à Secretaria da Educação, deveria ser reenquadrado junto à Secretaria de Governo, conforme proposta do Governador Lucas Nogueira Garcez, pois assim poderia servir às demais Secretarias com menos burocracia ${ }^{232}$.

Aquilo que fora iniciado como um "novo" espaço visando a publicação de transcrições de documentos teve seu perfil "restaurado" em 1961 quando de seu volume $\mathrm{XV}$, trazendo em suas páginas as "Atas do Conselho da Presidência da Província de São Paulo (1829),233. Os motivos dessa retomada teriam sido os constantes pedidos do público leitor. Nas palavras de César Teixeira Penteado, todo o material seria "manancial de excelente matéria para a descrição das personalidades

\footnotetext{
${ }^{230}$ Idem, 1947, vol. VII, pp. 05- 06.

${ }^{231}$ Em seu vol. X, de 1953, o Boletim apresentou as conferências ministradas no Curso Livre de Paleografia, oferecido pelo Arquivo no ano anterior. O vol. XIII, de 1954, trouxe, além de excertos dos programas de rádio transmitidos pelo Arquivo durante o ano de 1953, em emissora da capital, os relatórios do Secretário de Educação e do Diretor do Arquivo tratando da mudança das dependências do Arquivo para um prédio na r. Dona Antonia de Queiros (todo o acervo foi reorganizado e acondicionado em latas de alumínio). Além disso, foram dadas explicações sobre os motivos pelos quais o Arquivo não participaria de maneira mais intensa das comemorações do IV Centenário de São Paulo (parte da verba destinada fora cortado e dinheiro enviado ao Museu Paulista).

${ }^{232}$ Proposta publicada em Diário oficial de 25 de julho de 1951, no capítulo XXIII.

233 Tratava-se de continuação do material publicado no volume 86 dos Documentos interessantes. Vale salientar que em 1962 o volume XVI deu continuidade a essas atas, referentes ao período de 1832 a 1834.
} 
que, nos primórdios da independência política do país, constituíram o corpo diretivo de São Paulo" ${ }^{234}$.

A publicação de Documentos avulsos teve início apenas em 1952. Com apenas 6 volumes (1955), contou cada um deles com recortes cronológicos muito abrangentes. Criado para "substituir" o antigo Boletim do Departamento de Arquivo, as páginas dos Documentos avulsos dedicaram-se à publicação de transcrição referentes a documentos manuscritos existentes no acervo do Arquivo e que não poderiam ser publicados na série Documentos interessantes porque, na ocasião, ali estavam sendo editadas apenas as correspondências dos capitães generais. Para a direção do Arquivo a coleção seria nada menos que uma

$$
\begin{aligned}
& \text { "coletânea de ofícios, atos, provisões, bandos e de circulares } \\
& \text { de várias autoridades dirigidos aos mais diversos lugares da } \\
& \text { Capitania. Neles também vão publicados patentes de } \\
& \text { capitães-generais e nomeações que localizaram, por assim } \\
& \text { dizer, vultos e personalidades que participam da nossa } \\
& \text { história, no tempo colonial" "235. }
\end{aligned}
$$

Apesar do tempo, as preocupações da instituição para com a preservação e divulgação de seu acervo, bem como as políticas adotadas para tanto, sofreram poucas mudanças, numa clara manifestação de continuidade de determinados princípios intelectuais e acadêmicos. Em 1984 a equipe técnica do Arquivo do Estado iniciou os trabalhos de organização e transcrição de documentos referentes ao Registro de terras ${ }^{236}$. O primeiro volume foi publicado em 1986, referente aos registros promovidos na paróquia correspondente ao distrito da Sé. Até 1999 haviam sido publicados outros 4 volumes, dedicados respectivamente às regiões de São Francisco de Paula dos Pinheiros, São Miguel de Areias, Senhor Bom Jesus do Brás e Santa Ifigênia. Por tratar-se de material utilizado na confecção de certidões, a publicação desse conjunto garantiria não apenas a preservação e o acesso de

\footnotetext{
${ }^{234}$ AESP. Boletim. Op. Cit., 1961, vol. XV, p. 07.

${ }^{235}$ AESP. Documentos avulsos. São Paulo, Departamento de Arquivo, 1955, vol. VI, p. 05.

${ }^{236}$ Os 177 livros originais encontram-se sob guarda do AESP sob o título "Registros Paroquiais de Terras", produzidos entre os anos de 1854 e 1859 em atenção à Lei de Terras de 1850 (lei n 601, de 18 de setembro de 1850).
} 
pesquisadores acadêmicos às informações contidas nos documentos, mas também salvaguardariam direitos quanto à propriedade fundiária em São Paulo. Nas palavras do próprio corpo técnico do Arquivo, a publicação desse material representaria

"um valioso instrumento para o conhecimento da evolução da política agrária e da aplicação da legislação sobre terras no período, contribuindo para a construção da História Social e Econômica de São Paulo e do país" ${ }^{237}$.

A intenção desse breve panorama acerca das séries de publicações mantidas pelo Arquivo do Estado, especialmente no decorrer do séc. XX, foi municiar o leitor com referências que permitam avaliar a importância da série Documentos interessantes de maneira ainda mais complexa (iniciada ainda no séc. XIX, estendeu-se até meados da década de 1990), antes mesmo de iniciativas semelhantes provenientes de instituições congêneres, como é o caso do Arquivo Nacional. Apesar de seu pioneirismo e importância à época, conforme foi demonstrado, a própria instituição optou por ampliar sua linha editorial, mesmo que o perfil fosse preservado. Assim, documentos relacionados a São Paulo, em sua maior parte existentes no acervo da instituição, continuaram sendo selecionados, transcritos e publicados. A diferença dessas iniciativas para os Documentos interessantes é que, em alguns dos títulos, optou-se por preservar a seriação documental existente no acervo do próprio Arquivo do Estado, garantindo-lhes certa organicidade, diferentemente do que ocorria com os Documentos interessantes, selecionados e publicados seguindo-se os mais variados critérios, sempre em nome de um suposto interesse.

\section{2- Antonio de Toledo Piza e os Documentos interessantes}

\footnotetext{
${ }^{237}$ AESP. Registro de terras de São Paulo. São Paulo, AESP, 1999, p. 05.
} 
Desde sua criação (1892), a Repartição de Estatística e Arquivo teve como função preservar e disponibilizar os documentos armazenados pela extinta Secretaria de Governo, bem como produzir estudos estatísticos acerca das mais variadas questões administrativas.

Visando garantir a efetivação de suas atribuições, foram adotados mecanismos de "intercâmbio" com diversas instâncias, em âmbito federal, estadual e municipal $^{238}$. Assim, para melhor atender às demandas oriundas do público pesquisador, foram comuns as correspondências oficiais enviadas pelo Arquivo no sentido de buscar informações junto às Câmaras Municipais paulistas quanto a suas datas de instalação (tratava-se de atender a um pedido vindo do governo federal), além de informações sobre estradas de rodagem, empresas de viação, instituições de beneficência, entrada de imigrantes... Somente por meio dessas informações é que relatórios e quadros estatísticos- tão importantes para a construção da imagem de uma São Paulo moderna e em franco desenvolvimento- bem como orientar as melhores estratégias administrativas a serem adotadas (espírito cientificista), poderiam ser criadas.

Assim, foram comuns os ofícios enviados por Toledo Piza à Secretaria do Interior solicitando verbas para a aquisição de coleções de jornais e revistas produzidos em diferentes regiões do país. A intenção talvez fosse equipar a Repartição com um volume cada vez maior de informações, capazes de subsidiar seus trabalhos. Em 29 de outubro de 1894, Toledo Piza enviara uma correspondência a Cesário Motta Jr., pedindo dinheiro para a compra de uma coleção da Revista do Instituto Histórico e Geográfico Brasileiro ${ }^{239}$. Outro exemplo disso foi o ofício enviado ao General Bernardo Vasques (então Ministro da Guerra)

\footnotetext{
${ }^{238}$ Para atender a uma solicitação feita por João Sabino Damasceno (Diretor Geral de Estatística, no Rio de Janeiro), Toledo Piza enviou exemplares da Divisão administrativa do Estado, feita pela própria Repartição, em 22 de julho de 1902. Acervo AESP. Repartição de Estatística e Arquivo (correspondências), E 01438 (folha 258-9).

${ }^{239}$ Acervo AESP. Repartição de Estatística e Arquivo (correspondências), E 01436 (folha 21- 21v).
} 
pedindo cópia de mapa da capitania de São Paulo, datado de 1766, em posse do Arquivo Militar ${ }^{240}$.

Outra medida muito comum, visto não onerar o Estado, foram as constantes solicitações, junto às cidades do interior, que seus os órgãos jornalísticos enviassem à Repartição uma cópia de suas coleções e almanaques para que pudessem fazer parte do acervo. Em um pedido feito a J. J. Seabra (Ministro do Interior), em 09 de maio de 1902, Toledo Piza solicitava o envio do Diário Oficial da União para ser incorporado ao acervo ${ }^{241}$.

Em alguns casos, cabia à Repartição cobrar de algumas instituições, mesmo privadas, informações acerca de seu funcionamento, o que alimentava seus anuários estatísticos. Um dos exemplos pode ser percebido no ofício enviado pelo então Diretor Adolpho B. de Abreu Sampaio, em 14 de abril de 1909, para Carlos Augusto Pereira Guimarães (Secretário do Interior), pedindo informações administrativas sobre o Instituto histórico e geográfico de São Paulo e do Hospital de Misericórdia de Santo Amaro. Apesar de instituições privadas, ambos eram subvencionados pelo Estado $^{242}$.

Foram comuns também os contatos feitos por terceiros com o Arquivo oferecendo a eles os mais variados documentos. Esse foi o caso ofício de 13 de dezembro de 1895, enviado pelo secretário do Gabinete de Leitura de Sorocaba oferecendo, em doação, a documentação do órgão referente ao séc. XVIII ${ }^{243}$.

Apenas para ilustrar a importância de tal iniciativa, mesmo depois da morte de Toledo Piza o Arquivo deu continuidade a esta política. Em 1909 Abreu Sampaio era o Diretor da Repartição e coube a ele entrar em contato com o Barão do Rio Branco (Ministro das Relações Exteriores) solicitando uma relação de Ministros e

\footnotetext{
${ }^{240}$ Idem (folha 50, de 31 de janeiro de 1895; folha 363, respectivamente).

${ }^{241}$ Este foi o caso do ofício enviado ao redator do Correio de Jahu, em 17 de fevereiro de 1902. Para maiores informações ver: Acervo AESP. Repartição de Estatística e Arquivo (correspondências), E 01438 (folha 23940).

${ }^{242}$ Muitas vezes, a "aprovação" desses relatórios garantia a elas a própria manutenção desse vínculo. Acervo AESP. Repartição de Estatística e Arquivo (ofícios expedidos), E 11856 (folha 53).

${ }_{243}$ Trata-se do ofício $\mathrm{n}^{\circ}$ 454. Acervo AESP. Repartição de Estatística e Arquivo (protocolo de correspondências), E 01433 (folha 50).
} 
Cônsules brasileiros custodiados em outros países, para que a instituição pudesse lhes enviar uma cópia do Anuário estatístico de São Paulo, servindo verdadeiramente como ferramenta de propaganda do Estado no exterior ${ }^{244}$.

As preocupações com a preservação e acesso à documentação e informação mostraram-se comuns à instituição desde sua criação, mesmo que não ocupassem posição prioritária. Apesar da documentação pesquisada não trazer essa informação em profusão, um ofício assinado por Francisco José da Silveira Lobo indicava a seriedade com que a questão era conduzida. Trata-se de uma correspondência da Repartição para a Câmara Municipal da cidade de Assú (Rio Grande do Norte), datado de 20 de abril de 1892. Nela, o Diretor afirma ter no acervo um livro de Registro de Terras da freguesia de São João Batista, daquele município, e que deverá remetê-la à origem para não causar prejuízo de direitos aos possuidores nele registrados ${ }^{245}$.

$\mathrm{Na}$ intenção de viabilizar o acesso a todo esse material, sucessivas intervenções técnicas foram sendo propostas e levadas a cabo. Recorrentes mudanças de sede obrigavam o translado do material, assim como sua constante (re)organização. Nesse processo, descartes foram sendo efetuados em parcela significativas do acervo, amparados fossem pelo péssimo estado de conservação dos originais, fossem pela suposta inutilidade dos mesmos ao exercício administrativo ou garantia de direitos.

A nomeação de Antonio Toledo Piza como Diretor da instituição (1893) ${ }^{246}$, abriu possibilidades diversas ao direcionamento intelectual dos paulistas, com propostas autônomas em relação ao establishment nacional. Já em seu primeiro relatório, apresentado em 31 de julho de 1894, apontava para a necessidade de

\footnotetext{
${ }^{244}$ Acervo AESP. Repartição de Estatística e Arquivo (ofícios expedidos), E 11856 (folha 25, de 18 de fevereiro de 1909).

${ }^{245}$ Acervo AESP. Repartição de Estatística e Arquivo (correspondências), E 01434.

${ }^{246}$ O primeiro Diretor da Repartição de Estatística foi Francisco José da Silveira Lobo, Tenente-Coronel da Guarda Nacional. Nascido em Alagoas, tinha sido secretário da Sociedade Promotora de Imigração e, em 1892, ocupava um cargo nos Feitos da Fazenda. Foi iniciativa dele as primeiras intervenções de classificação dos documentos e formação da biblioteca. Também foi de sua iniciativa um acordo com a Diretoria Geral de Estatística da União. Foi substituído em 09 de maio de 1893 por Antonio de Toledo Piza e Almeida. Para maiores informações ver: AMARAL, A. B. do. O departamento de arquivo. Op. Cit.
} 
publicação de documentos que pudessem ser de interesse à "história e costumes dos paulistas nos tempos coloniais" 247 . As parcerias com diversos particulares, bem como Câmaras Municipais e outras instituições, especialmente o IHGSP, foram colocadas como prioritárias desde muito cedo ${ }^{248}$. Paralelamente a uma de suas funções legais, qual seja, a de produção e análise de dados estatísticos, em seu arquivo foram sendo armazenados documentos de origens diversas, fossem eles produzidos pelo poder público, cartórios, ou recolhidos junto a famílias ilustres de São Paulo. Toledo Piza entrava em contato com todos eles e pedia para que remetessem à Repartição papéis originais, ou cópias, de tudo aquilo que fosse considerado importante ${ }^{249}$. Em circular de 07 de maio de 1904, o Diretor solicitava a todos os Presidentes de Estado que enviassem coletâneas de atos administrativos para que pudessem constar da coleção da Repartição ${ }^{250}$.

Em ofício endereçado a Cesário Motta Jr, em 06 de fevereiro de 1894, Toledo Piza falava da existência de documentos eclesiásticos sob a posse da Câmara Municipal de Faxina, que deveriam ser recolhidos ${ }^{251}$. Outro exemplo do empenho da Repartição em recolher documentos considerados úteis e importantes para a história de São Paulo está a carta de Toledo Piza ao presidente da Câmara de Itanhaém, em 13 de março de 1896. Nela foi solicitado o envio para a instituição dos livros de Registros de Terras existentes nessa Câmara para fins de direitos e pesquisa ${ }^{252}$.

Visando publicizar todo esse material, bem como os documentos existentes em diversos acervos do país, a Repartição deu início à série denominada

\footnotetext{
${ }^{247}$ Idem, p. 54.

${ }^{248}$ Os vínculos existentes entre o Instituo Histórico e Geográfico de São Paulo e o Arquivo do Estado são muito mais profundos do que se pode imaginar. Apenas para ilustrar, vale lembrar que Antonio de Toledo Piza, responsável pelo início das publicações do Arquivo com a série Documentos interessantes, foi também um dos "ilustres paulistanos" responsáveis pela criação do IHGSP, no mesmo ano de 1894.

${ }^{249}$ Atendendo a esse pedido, a Câmara de Cananéia enviou, por empréstimo, quatro volumes de documentos antigos "para ser deles extraído tudo quanto houvesse de interesse". AMARAL, A. B. do. O departamento de arquivo do estado. Op. Cit., p. 54.

${ }^{250}$ Acervo AESP. Repartição de Estatística e Arquivo (correspondências), E 01438 (p. 362).

${ }^{251}$ Acervo AESP. Repartição de Estatística e Arquivo (correspondências), E 01434 (folha 181v).

${ }^{252}$ Acervo AESP. Repartição de Estatística e Arquivo (correspondências), E 01436 (folha 128-128v).
} 
Documentos interessantes para a história e costumes de São Paulo ${ }^{253}$. O intuito era disponibilizar ao público cópias documentais transcritas, autênticas e fidedignas, capazes de permitir um trabalho sistemático de historiadores. Um dos primeiros registros encontrados no acervo do Arquivo do Estado sobre esse assunto diz respeito a um ofício enviado pelo Diretor a Motta Jr. solicitando dinheiro para a publicação de documentos relativos à história de São Paulo, existentes no acervo do Arquivo $^{254}$.

Se por um lado, as escolhas feitas pela direção do Arquivo sobre quais documentos reproduzir e preservar (avulsos ou em série) foram supostamente motivadas por questões "técnicas" (fragilidade do suporte ou risco de perda da informação devido à ação de umidade ou agentes biológicos), por outro, esta publicação expressa de maneira significativa a forma com que se pensava o fazer história, em uma clara demonstração da ação constitutiva de uma representação sobre um passado "glorioso e heróico". Especial atenção foi dada ao período colonial, fazendo com que a figura do bandeirante fosse sendo (re)alimentada e consolidada como o grande agente promotor de modernidade e desenvolvimento do território nacional.

Para Ana Maria Camargo e Heloísa Bellotto a iniciativa estaria relacionada ao esforço de confecção de um tipo de instrumento de pesquisa conhecido como Catálogo Seletivo (o mesmo que Repertório), tomando por unidade básica de descrição documentos previamente selecionados, pertencentes a um ou mais fundos ou arquivos, seguindo-se critérios temáticos. Tal iniciativa não poderia ser confundida com a elaboração de um Guia de Fontes, pois este teria por função

\footnotetext{
${ }^{253}$ Uma relação do material que deu origem ao acervo da Repartição de Estatística e Arquivo, oriunda da extinta Secretaria de Governo, aponta tratar-se de documentação sobre os mais variados assuntos, produzidos entre os anos de 1821 e 1886. São eles: documentos sobre Instrução Pública, Câmaras Municipais, Tesouraria/ Tesouro Provincial, Cadeia, Ofícios Diversos, Qualificação de Votantes, Alistamento/ Mesa Eleitoral, Ministérios, Juízes de Direito, Corpo de Permanentes, Penitenciária, Casa de Correção, Polícia, Obras Públicas, Mesas de Renda, Guarda Nacional, Estatísticas. Acervo AESP. Repartição de Estatística e Arquivo (catálogo de documentos da Secretaria do Governo), E 01464.

${ }^{254}$ Acervo AESP. Repartição de Estatística e Arquivo (correspondências), E 01434 (folha 191v, de 12 de maio de 1894).
} 
identificar e localizar fundos, grupos ou séries, de um ou mais arquivos, seguindo-se critérios temáticos, coisa que os Documentos interessantes não fazem ${ }^{255}$.

É importante salientar que a tomada de decisão sobre organizar, ou não, um conjunto documental reafirmaria a condição deste mesmo material como "morto" ou "vivo" aos olhos do público pesquisador.

"A idéia de uma massa passiva e inerte de documentos parece comumente associada ao trabalho de organização de acervos documentais de qualquer natureza. Todavia, se colocada em movimento- através de instrumentos de público acessotorna-se o elemento vitalizante de inúmeros setores, em função dos quis sua existência é justificada. É por esse estreito vínculo com uma realidade que lhe é exterior que toda documentação potencial passa a ser incorporada a um ou mais sistemas atualizados de informação"256.

O grande problema de ações como as promovidas pela Repartição de Estatística e Arquivo, por meio de seus Documentos interessantes, seria a de criar uma falsa aparência quanto à realidade do potencial informativo presente na massa documental depositada no acervo da instituição. Por comodidade, ou mesmo ignorância, muitos pesquisadores poderiam imaginar tratar-se de toda a documentação existente no Arquivo acerca de um determinado assunto, especialmente aqueles ligados à origem paulista, e não de uma seleção, que seguira critérios muito próprios e pouco explicitados que, por vezes, abdicou de qualquer preocupação quanto à manutenção da organicidade do material ${ }^{257}$.

$\mathrm{Na}$ opinião de Jean Glénisson a edição de documentos exigiria atenção quanto à seleção, leitura paleográfica, análise diplomática, identificação de datas e

\footnotetext{
${ }^{255}$ CAMARGO, Ana Maria de Almeida, BELlOTTO, Heloisa Liberalli (coord.). Dicionário de terminologia arquivística. São Paulo, AAB-SP/SEC, 1996.

${ }^{256}$ CAMARGO, Ana Maria de Almeida. A imprensa periódica como objeto de instrumento de trabalho: catálogo da hemeroteca Júlio de Mesquita do Instituto Histórico e Geográfico de São Paulo. Tese de Doutorado apresentada na FFLCH da Universidade de São Paulo, 1975, p. 14.

${ }^{257}$ Conforme apresentado na Introdução desse trabalho, o que torna a publicação dessa série ainda mais intrigante é que, mesmo com o avanço técnico da arquivística ao longo do séc. XX, além das próprias transformações ocorridas no seio da história, com todas as novidades metodológicas propostas a partir da chamada escola dos Analles, o Arquivo do Estado continuou adotando os mesmos procedimentos de seleção e publicação de documentos.
} 
nomes, além das determinações dos fatos históricos ${ }^{258}$. No caso dos Documentos interessantes, em seus primeiros anos todas essas preocupações ficavam a cargo do próprio Toledo Piza. Exatamente aí talvez resida o ponto crucial das críticas elaboradas por Heloísa Bellotto. Para ela, apesar de iniciativa legítima, os motivos da escolha dos documentos nunca ficam muito claros, ou seguem critérios científicos, ficando à mercê das "seleções ao gosto dos diretores ou ao sabor de algumas pesquisas em voga" 259 .

Para Theodore Schellenberg, um dos pontos positivos desse tipo de publicação seria a de "tornar acessível os documentos que são inacessíveis devido a características físicas" ${ }^{260}$, visto ser a fragilidade dos suportes documentais um critério recorrente apontado como motivador da seleção. Vale lembrar que, tecnicamente, esse tipo de intervenção acarretaria, como subproduto, na preservação dos próprios originais, protegendo-os do manuseio constante por parte do público interessado.

Além disso, em muitos casos, esse tipo de iniciativa tornaria acessível o conteúdo das fontes primárias a um número maior de pesquisadores devido à adoção de mecanismos de intervenção técnica, especialmente a paleografia, agrupando informações "segundo critérios ligados não a uma necessidade prática interna, mas sobretudo a uma necessidade científica" 261 .

Schellenberg chegou mesmo a defender o recurso da microfilmagem como meio para a obtenção de cópias fidedignas aos originais, capazes de preservarem não apenas informações descritivas sobre sua composição e conteúdo, mas também uma imagem do próprio documento, permitindo ao investigador ampliar suas próprias conclusões. No caso dos Documentos interessantes, a vantagem de se manter uma linha editorial e não uma rotina de reprodução analógica de documentos era a de

\footnotetext{
${ }^{258}$ GLÉNISSON, Jean. Introdução aos estudos históricos. São Paulo, DIFEL, 1961.

259 BELLOTTO, Heloísa Liberalli. Arquivos permanentes: tratamento documental. Rio de Janeiro, Editora FGV, 2004, p. 217.

${ }^{260}$ SCHELLENBERG, Theodore R. Arquivos modernos: princípios técnicos. Rio de Janeiro, FGV, 2002, p. 330.

${ }^{261}$ CAMARGO, A. M. de A. A imprensa periódica. Op. Cit., p. 16.
} 
permitir a reprodução do mesmo material em larga escala, possibilitando uso/ divulgação em diversas instituições de pesquisa e difusão, sem as dificuldades inerentes ao microfilme, apesar de não possuir o mesmo amparo legal que esse tipo de reprodução tem quanto ao valor de original ${ }^{262}$.

Com uma visão mais contemporânea, André Ancona Lopez defende a tese de que a importância "atribuída a determinados documentos é sempre embasada em critérios alheios às atividades do arquivo" 263 . Não caberia, como função primeira deste tipo de instituição, a produção de repertórios (atualmente conhecidos por catálogos seletivos) ou mesmo a escolha de documentos a serem publicados, independentemente dos critérios adotados. Sendo os arquivos instituições ligadas muito mais à administração, garantidoras de direitos, que à pesquisa acadêmica, deveriam dedicar-se a produzir meios de acesso a um volume cada vez mais amplo de documentos, deixando-se de lado interesses pessoais ou efemérides ${ }^{264}$. Definitivamente, esse não foi o caso dos Documentos interessantes visto terem surgido na própria gênese da Repartição, como uma de suas principais atividades. Nesse caso, a seleção e publicação de documentos garantiria visibilidade ao acervo, permitindo sua utilização por parte de historiadores, especialmente os vinculados ao IHGSP, na apropriação e legitimação de uma identidade paulista imbuída de um espírito pioneiro e empreendedor (quase republicano).

Pioneira, a edição da série foi iniciada em 1894 e estendida até 1990, sendo a responsável por implantar e consolidar uma política de reprodução documental que

\footnotetext{
${ }^{262}$ É importante salientar que a preocupação técnica quanto ao valor e uso dos microfilmes é bem mais recente que o início da série Documentos interessantes. A primeira lei que passou a amparar o uso da microfilmagem como recurso legal válido para a reprodução de documentos com o mesmo valor dos originais é de 1968 (lei no 5.433). Se por um lado a microfilmagem representaria uma possibilidade de preservação dos originais, por outro, não poderia ser vista como um mecanismo permissivo à eliminação dos documentos originais visando a liberação de espaço. Vale lembrar ainda que, apesar das dificuldades, a publicação desta série estendeu-se, mesmo que maneira irregular, até o ano de 1990, quando a prática de microfilmagem já era uma realidade consolidada no próprio Arquivo do Estado.

263 LOPEZ, André Ancona. Como descrever documentos de arquivo: elaboração de instrumentos de pesquisa. São Paulo, AESP/ Imesp, 2002, p. 39. Vale lembrar que essa mesma idéia também é defendida por Heloísa Liberalli Bellotto em Arquivos permanentes: tratamento documental. Rio de Janeiro, Editora FGV, 2004.

${ }^{264}$ Apesar delas representarem, muitas vezes, as únicas oportunidades efetivas de obtenção de recursos, tanto junto ao poder público como com particulares, para a organização de um segmento de acervo.
} 
extrapolaria as próprias fronteiras dos Documentos interessantes, passando a ser adotada pelo Arquivo em inúmeras outras publicações, conforme visto anteriormente.

Na visão de Armando Prado (responsável pelo volume 44 dos Documentos interessantes) teria sido do próprio Antonio de Toledo Piza a idéia de publicar a série, na época em que ocupava o cargo de Diretor da Repartição de Estatística e Arquivo $^{265}$. Tratava-se de uma proposta editorial que atendia à demanda por acesso fácil e ágil às "fontes históricas relativas a São Paulo, existentes nos arquivos do Estado e nos de suas Municipalidades, mas também em mãos de particulares"266. Teria sido dele os "pacientes trabalhos de pesquisa, escolha, cópia, anotação e publicação de livros e papéis antigos, concernentes aos fastos paulistas" 267 .

Apenas para ilustrar as dimensões da empreitada, o volume 39 da coleção será utilizado como exemplo ${ }^{268}$. Nele, aparentemente, foram transcritos na íntegra todos os registros existentes em um único códice, o de $\mathrm{n}^{\circ} 115$, referente às correspondências enviadas pelo Governador e Capitão General da capitania de São Paulo, Antonio Manoel de Mello Castro e Mendonça, entre 1797 e 1803, preenchido pelo secretário de governo Luis Antonio Neves de Carvalho ${ }^{269}$.

Nascido na cidade de Capivari (interior de São Paulo), Toledo Piza ainda jovem mudou-se para Porto Feliz ocupando a cadeira de professor primário até 1874. No ano seguinte, devido a problemas de saúde, foi para os Estados Unidos, aproveitando a estadia para estudar engenharia civil na Universidade de Cincinati

\footnotetext{
${ }^{265}$ Nessa mesma época, além de participar da criação do IHGSP, também foi nomeado como responsável pela edição da Revista do Instituto.

266 PRADO, Armando. "Antonio de Toledo Piza". In: AESP. Documentos interessantes para a história e costumes de São Paulo. São Paulo, Casa Eclética, 1915, vol. 44, p. 03.

${ }^{267}$ Ibidem.

${ }^{268}$ Trata-se da "Correspondência do Capitão General Antonio Manoel de Mello Castro e Mendonça" (17971803), sendo o primeiro documento o termo de abertura do livro.

269 Vale lembrar que todo esse material nada mais seria que o registro de minutas referentes aos ofícios expedidos pelo Governador. Apesar dessa condição, este material não pode ser visto como uma documentação "menor". Para Ana Maria Camargo e Heloísa Bellotto, esta seria apenas uma forma de expressão de um documento "antes de sua feição definitiva" que, embora não apresente os sinais de validação (chancelas, selos, assinaturas...) já foi devidamente revisado. Para muitos especialistas, este tipo de documento não poderia ser confundido com um rascunho. Ver: CAMARGO, A. M. de A., BELLOTTO, H. L. (coord.). Dicionário.. Op. Cit.
} 
(Ohio). Em seu regresso ao Brasil (1880) tornou-se Diretor técnico do Engenho Central de Porto Feliz.

Contando com certa experiência na lida com equipamentos pesados (ainda nos EUA participara da construção de estradas de ferro no Kentucky e Tennessee) foi encarregado por Joaquim de Salles \& Comp para representar a empresa junto a fornecedores estadunidenses e adquirir o maquinário necessário para a instalação da unidade fabril da cervejaria Antártica Paulista, na capital de São Paulo (1885).

Em seguida mudou-se para o interior de São Paulo (Jaboticabal e Araraquara, respectivamente), atuando na divisão de terras e construção de edificações. Como funcionário público, foi nomeado engenheiro da Secretaria de Obras Públicas de São Paulo, cargo que ocupou entre 1891 e 1893, quando da sua nomeação para Diretor da Repartição de Estatística ${ }^{270}$.

Apesar de uma formação técnica, Toledo Piza sempre manteve estreitas ligações com o cenário acadêmico e jornalístico. Ainda morando nos EUA, escreveu artigos sobre temas ligados à política e economia do Brasil, colaborando com a Província de São Paulo (entre 1886 e 1888), Folha do Povo de Araraquara, Correio Paulistano e Diário Popular (estes dois últimos na capital paulista).

$\mathrm{Na}$ época em que assumiu a Repartição, uma das queixas administrativas mais comuns versava sobre a falta de centralização dos cálculos estatísticos, feitos parcialmente em diferentes instituições, o que dificultava qualquer tipo de intervenção "cientificamente sistematizada" por parte do poder público. Responsável pela organização dos serviços estatísticos do Estado, foi sob sua direção que os primeiros anuários foram publicados (1904), referentes ao ano de 1901. Nas palavras de Armando Prado,

"O êxodo dos campos para as cidades; a imoralidade doméstica avaliada pelo maior ou menor número dos nascimentos ilegítimos; as íntimas correspondências dessa imoralidade com as tabelas do crime; a inexistência de leis físicas ou morais que presidam a proporcionalidade dos matrimônios com relação aos nascimentos; os costumes da

\footnotetext{
${ }^{270}$ Este cargo foi ocupado por ele até sua morte em 1905.
} 
população concernentes aos regimes de bens no casamento; o horrível coeficiente da letalidade infantil, que o levou a chamar São Paulo- o açougue das crianças; a determinação das regiões do Estado onde a vida é mais enérgica e ativa; o grau de cultura intelectual do povo; a constatação da preponderância dos estrangeiros nesta Capital e o grau de simpatia que eles dedicavam à nacionalidade brasileira, tirando esse grau das tábuas de naturalização, cujos dados permitiram esta sugestiva inferência: os alemães foram os que mais se identificaram conosco, ao passo que os italianos, os portugueses e os espanhóis nenhum interesse tomaram pela vida política do país- eis os problemas que ele agitou nas centenas de páginas de seus relatórios.

(...) afirmou que os estrangeiros eram cinco vezes mais prolíferos que os nacionais; casavam-se mais e morriam em menor proporção que estes e, por isso, constituíam-se o agente principal do povoamento do território paulista" ${ }^{271}$.

Ao longo de suas análises, é possível perceber a rejeição de Toledo Piza à máxima de que "abrir escolas é fechar cadeias"272. Mediante leitura cuidadosa dos dados coletados pela Repartição, fora possível ao Diretor aferir que "somente a educação moral, aquela que se recebe no seio da família, a educação do sentimento, é que preserva os homens dos vícios e dos crimes" ${ }^{\text {273 }}$. Isso não quer dizer que ele tenha se mostrado refratário a políticas educacionais mantidas pelo poder público.

Em nota explicativa, incorporada a uma carta enviada ao Conde de Oeiras pelo Capitão General Luiz Antonio de Souza Botelho Mourão, Toledo Piza aponta para a educação como uma ferramenta eficiente na docilização dos colonos no sertão, deixando de lado questões como a pequena propriedade e o agrupamento da população em povoados. De acordo com suas palavras,

"Para que o povo não se embrutecesse o Capitão General não se lembrava da escola e do ensino primário, e aconselhava reuni-lo em povoações de 50 famílias para cima para que não vivesse disperso e insociável. Agora pretende distribuir terras

\footnotetext{
${ }^{271}$ PRADO, A. “Antonio de Toledo Piza”. Op. Cit., p. 06.

${ }^{272}$ Esse princípio norteou um grande volume de ações do poder público em seu período republicano. Muitos desses esforços foram amparados pela própria Repartição e seus Documentos interessantes, distribuídos para todas as bibliotecas escolares de São Paulo no afã de servirem de material "ilustrativo" da grandeza do povo paulista.

${ }^{273}$ PRADO, A. “Antonio de Toledo Piza”. Op. Cit., p. 07.
} 
em pequenos lotes e constituir a pequena propriedade, com pequeno estipêndio para as Secretarias do Governo e Conselho Ultramarino. Só esse pequeno estipêndio, pago em Lisboa, com as despesas acessórias de procurador, requerimentos, selos, etc, absorveria o valor da pequena propriedade e ainda o camponês ficaria a dever. $\mathrm{O}$ governo português, nem mesmo no tempo de Pombal, não queria o progresso do Brasil, e por isso os esforços de D. Luiz Antonio ficaram perdidos" 274 .

Apesar disso, boa parte dos esforços que o Diretor dedicou à frente da Repartição dizia respeito à preservação, transcrição e divulgação sistemática de documentos pertencentes ao acervo de seu Arquivo, estivesse ele organizado em códices ou apenas enfeixados em maços de material avulso ${ }^{275}$. Contando com o apoio do Secretário dos Negócios do Interior, Cesário Motta Jr, ainda no final do séc. XIX (início do período republicano) foi principiada a publicação dos

\section{Documentos interessantes.}

“(...) é claro que os arquivos não se fizeram para ficarem segregados ao conhecimento dos estudiosos e à utilidade do povo. De onde, a imprescindível necessidade de se propagarem os documentos nele guardados. Essa necessidade é urgente em se tratando dos arquivos de São Paulo, não só pelo estado precário em que se vêem muitíssimo dos seus melhores manuscritos, se não também pela intervenção contínua de São Paulo nos acontecimentos da história nacional.

Salvando da destruição de um grande número de códices, que se achavam no arquivo, e descobrindo fora dele muitas memórias preciosas, a ação do nosso incansável paleógrafo foi das que merecem a gratidão pública"276.

No decorrer dos 11 anos em que ficou à frente da empreitada, Toledo Piza foi o responsável pela publicação de 43 volumes da coleção, dando sempre preferência a temas ligados aos períodos colonial e imperial brasileiro, com especial atenção

\footnotetext{
274 AESP. Documentos interessantes. São Paulo, Casa Eclética, 1896, vol. 20, pp. 09- 10.

275 De acordo com seus biógrafos, Toledo Piza dedicava horas do seu dia à leitura e transcrição de documentos antigos utilizando-se de lentes e ácidos. Para uma melhor leitura, punha-se nos jardins do prédio, em plena luz do sol, para melhor transcrever as informações registradas em documentos danificados.

${ }^{276}$ PRADO, A. “Antonio de Toledo Piza”. Op. Cit., pp. 08- 09.
} 
para a participação de São Paulo nesses $\operatorname{processos}^{277}$. Nas palavras do próprio Diretor, o volume de material relevante para o estudo da história de São Paulo existente no acervo da Repartição era tamanho que seria possível publicar um exemplar de Documentos interessantes por mês ${ }^{278}$. Para Armando Prado,

"Os prodronos em São Paulo da nossa independência política, com a organização dos governos provisórios de 1821 e 1822 e o patético enforcamento do Chaguinhas, de que as lendas se apoderaram; a bernarda de Francisco Ignácio com todos os complicados temas que suscita sobre a ação dos Andradas; a fundação do presídio de Iguatemi, doloroso lance de nossa história, em que se vêem os paulistas subordinados ao egoísmo e avareza da metrópole e aos caprichos tirânicos dos seus prepostos, que depois de fundarem a povoação à custa de inaudito sofrimento do povo, entenderam de abandoná-la a uma destruição trágica; a importantíssima questão das confrontações entre São Paulo e Minas Gerais; os descobrimentos das minas de Cuiabá e de Goiás, o tremendo assassinato oficial dos irmãos Leme e as várias vicissitudes do governo de Rodrigo Cezar de Menezes, que marca a passagem dos paulistas da vida nômade de faiscadores de ouro para a vida sedentária da agricultura; os fastos dos governadores que mais ou menos acabrunharam São Paulo no período que vai de 1721 até o surto da independência; o aspecto geográfico, os movimentos da população, o estado financeiro, a estrutura militar, a situação econômica, a organização eclesiástica, as expedições guerreiras, o organismo das leis, as medidas políticas e administrativas, enfim todas as manifestações da vida do povo e do estadoeis, em epítome, a matéria dos Documentos Interessantes, sem os quais ninguém poderá abalançar-se a escrever a história de São Paulo,279.

Como nem só o poder público era detentor de documentos considerados importantes para a história de São Paulo, Toledo Piza buscava junto a particulares novos materiais. Esse foi o caso do material oriundo do espólio de José Arouche de

\footnotetext{
${ }^{277}$ Se levarmos em conta que o último volume, de número 95, foi publicado em 1990, é fácil constatar sua importância. Em apenas 11 anos sob seu comando, a Repartição publicou aproximadamente $45 \%$ de toda a coleção, demorando outros 81 anos para publicar o restante (47 volumes).

${ }^{278}$ Trata-se de comentário inserido no relatório apresentado pelo Secretário Cesário Motta Jr, em 1895, à Presidência do Estado. GOVERNO DE SÃO PAULO. Relatório da Secretaria dos Negócios do Interior. São Paulo, Tipografia Vandorden, 1895, p. 09.

${ }^{279}$ PRADO, A. “Antonio de Toledo Piza”. Op. Cit., pp. 09-10.
} 
Toledo Rendon. Autorizado pela família, Toledo Piza pode entrar na casa pertencente ao titular, situada no largo do Arouche, e recolher todo o material que lhe interessasse. Lá encontrou, exposto à chuva, um grande volume de laudas, muitas delas danificadas irremediavelmente. Dentre elas estavam a narrativa sobre a descoberta de minas de ouro em Guarapuava, cartas de Pedro Taques a frei Gaspar da Madre de Deus, estudos realizados por esse mesmo frei sobre a fundação da capitania de São Vicente, manuscritos sobre a expulsão dos jesuítas de São Paulo... Esse material acabou sendo incorporado ao acervo do Arquivo, e suas respectivas transcrições terminaram por ser publicadas tanto nas páginas dos Documentos interessantes como na Revista do IHGSP, que Toledo Piza era um dos responsáveis.

Outro exemplo de valorização da documentação privada diz respeito ao esforço empreendido pelo Diretor da Repartição no sentido de recolher documentos “importantes" junto a cartórios. Com isso, parcela significativa desse material pode vir a público fosse por meio de sua reprodução ou por textos analíticos publicados em revistas dedicadas a temas de história regional. Tais iniciativas objetivavam dar vazão aos preceitos metodológicos defendidos por Langlois e Seignobos, na medida em que colecionar documentos e subordiná-los ao processo de análise crítica seriam os primeiros passos rumo a uma construção histórica eficiente sobre São Paulo ${ }^{280}$.

Uma leitura atenta de todo o material publicado permite estabelecer que os critérios de seleção utilizados para a publicação foram os mais variados, não seguindo ordem cronológica obrigatória. Um dos motivos talvez tenha sido o desejo de reproduzir, visando uma tentativa de preservação, todo o material que se encontrava em precário estado de conservação, independentemente da idade.

\footnotetext{
${ }^{280}$ Apenas para registrar, de acordo com a publicação História do arquivo público de São Paulo os documentos publicados nos volumes de números 01 a 03,07 a 09, 13, 15 e 27 da série Documentos interessantes não aparecem identificados no acervo do Arquivo. Talvez todos eles sejam fruto de pesquisas externas, ou mesmo seleções feitas junto a segmentos do acervo sem que tivesse sido identificado a procedência dos originais. Como o instrumento de pesquisa traz a relação apenas do material encadernado, é possível que existam documentos avulsos, sem identificação. AESP. Histórico do archivo público de São Paulo; acompanhado da relação dos cidadãos que governaram a província e o estado. São Paulo, Duprat, 1908.
} 
Todo esse esforço de preservação e divulgação de documentos, bem como a produção de seus estudos estatísticos, franquearam a Toledo Piza uma vaga como sócio correspondente do Instituto Histórico, Geográfico e Estatístico Brasileiro (proposta feita de 1895, após a publicação da Estatística de São Paulo em 1894 e dos Documentos interessantes). A seção de 11 de agosto de 1895 aprovou-o com o seguinte parecer, assinado por Américo Brasiliense e Cesar Marques:

“A comissão de História, tendo em vista a proposta de 19 de maio, relativa á admissão do Sr. Dr. Antonio de Toledo Piza para sócio correspondente deste Instituto, é de parecer que seja a mesma aprovada.

A proposta indica como título de admissão o trabalho ultimamente publicado- Estatística do estado de São Paulo, e bem assim outros escritos não menos importantes, que tem sido dado à luz, e recentemente o $13^{\circ}$ volume da utilíssima obra histórica denominada: Documentos interessantes para a história e costumes de São Paulo.

O Sr. Dr. A. Piza, diretor do Arquivo Público daquele estado, tem dado sobejas provas de sua atividade intelectual e dedicação ao estudo de acontecimentos da nossa pátria, como se evidencia das suas publicações dignas de apreço, e muitos bons auxílios prestará a este Instituto" ${ }^{281}$.

Em uma de suas colaborações nesse instituto pode ser lido um artigo seu sobre a igreja existente no colégio jesuítico de São Paulo. Trata-se de um texto publicado na sua revista do $\mathrm{IHGB}^{282}$ em que Toledo Piza discorre sobre a fundação da cidade; a ereção da primeira igreja, a fim de abrigar os "catecúmenos indígenas", bem como sua participação na paisagem local até a construção do moderno templo da "urb contemporânea", que viu ruir a antiga estrutura "numa noite de grandes chuvaradas" $" 283$.

Parte de seus esforços como historiador também podem ser constatados quando da análise de seus escritos, publicados na Revista do Instituto Histórico de São Paulo. Seu primeiro trabalho nesse periódico diz respeito às divisas entre o

\footnotetext{
${ }^{281}$ Idem, p. 11.

${ }^{282}$ IHGB. Revista do Instituto Histórico e Geográfico Brasileiro. Rio de Janeiro, Companhia Tipográfica do Brasil, 1896, tomo 59, $2^{\text {a }}$ parte, pp. 57- 150.

${ }^{283}$ PRADO, A. “Antonio de Toledo Piza”. Op. Cit., pp. 23- 24.
} 
estado de Santa Catarina e Paraná. Tratava-se de matéria de grande interesse visto que, ainda no início do séc. XX, existiam divergências sobre sua localização. Nesse trabalho Toledo Piza reconstruiu minuciosamente os diversos desmembramentos da capitania de São Paulo, assim como as vicissitudes dos administradores coloniais diante da descoberta de ouro em Minas Gerais e Goiás.

"Continuava São Paulo a ser a célula mater que, após desenvolver-se pela audácia cruel mas proveitosa dos bandeirantes, destacava de si enormes porções de chão povoado por gente civilizada" 284 .

De acordo com o pensamento corrente na época, não seria a primeira, nem mesmo a última vez que São Paulo seria sacrificado em benefício do Brasil.

$\mathrm{Na}$ análise de Toledo Piza, a administração de D. Luiz Mascarenhas (responsável pela capitania entre 1739 e 1748) teria posto fim ao primeiro período da história colonial de São Paulo. Para ele

"Aquelas famosas de intrépidos bandeirantes paulistas que, com Antonio Raposo, tinham desbravado o Goyará, assolado as missões dos jesuítas de além Uruguai e Corrientes, e ido dar combate aos espanhóis sobre os Andes; que, com Luiz Pedroso de Barros, foram combater com o inimigo estrangeiro no Recôncavo da Bahia, e depois travaram novos combates contra os espanhóis, no Peru; que, Pedroso Xavier, invadiram o Paraguai, e de lá trouxeram ricos despojos; que, Domingos de Brito, fundaram a vila da Laguna e exploraram as campinas do sul até o Rio da Prata; que, João Amaral Maciel Parente, invadiram e devassaram os sertões do norte até o Piauí e Maranhão; que, com Domingos Jorge, foram os únicos capazes de destruir a legendária república africana dos Palmares; que com Raposo Tavares, foram a Pernambuco auxiliar a restauração do domínio português contra o poder dos holandeses; que, com Fernando Dias Paes, tinham descoberto as riquezas de Minas Gerais e enchido a Europa de inveja da opulência do subsolo brasileiro; que, com Paschoal Moreira Cabral e Bartholomeu Bueno da Silva haviam explorado e povoado os sertões de Mato Grosso e de Goiás e exibido ao mundo os tesouros ocultos que encerravam, tinham todos desaparecido para sempre, para serem substituídos por outras gerações pacíficas de

\footnotetext{
${ }^{284}$ Idem, p. 17.
} 
cultivadores das terras e exploradores das minas já
conhecidas ${ }^{\text {285 }}$.

Para o historiador e estatístico seria este o momento da mudança no perfil do paulista. Sempre dedicado ao crescimento local, e a reboque trazendo todo o restante do Brasil, deixava de ser um faiscador de ouro constantemente envolvido em conflitos militares e crimes, pelo menos aos olhos das autoridades metropolitanas, para se dedicar à agricultura, de maneira pacífica e fortemente vinculada ao solo. Este último aspecto teria sido decisivo para o desenvolvimento de São Paulo, colocando a capitania, até então periférica na lógica colonial, como região destacada na economia imperial ${ }^{286}$.

Em seu segundo trabalho publicado na Revista do IHGSP, Toledo Piza tratou da expulsão dos jesuítas de solo brasileiro, especialmente paulista. Ao analisar esta questão, Armando Prado aponta para um problema: como realizar a agricultura sem contar com os braços que apenas os indígenas poderiam oferecer em abundância, economia e relativa facilidade? O posicionamento contrário dos jesuítas ao cativeiro tornara-se um entrave à exploração agrícola do solo, assim como à manutenção da população e do próprio território colonial. "Era fatal fossem combatidos e

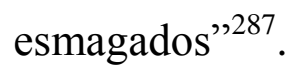

Em boa parte de seus trabalhos historiográficos, fossem eles publicados no IHGB ou IHGSP, Toledo Piza tecia duras críticas àqueles que defendiam a idéia de que os paulistas eram regionalistas e com tendências ao separatismo. Ao contrário, em sua opinião, esta seria a região que mais abriu mão de territórios, sacrificando-se em nome da grandeza pátria. No caso da escassez de sal e do militarismo da capitania como causas de seu sofrimento, Piza escreveu importantes artigos demonstrando que, se por um lado, o militarismo trouxe malefícios, também não

\footnotetext{
${ }^{285}$ Idem, p. 18.

286 Para Toledo Piza os constantes desmembramentos das regiões auríferas em relação à capitania, promovidos pela metrópole portuguesa, teriam atuado de maneira decisiva nesse processo, transformando a agricultura, originalmente única alternativa, em meta das atividades econômicas paulistas.

${ }^{287}$ PRADO, A. “Antonio de Toledo Piza”. Op. Cit., p. 19.
} 
deixou de beneficiar a colônia, especialmente com a aquisição e preservação de enormes territórios.

"Não resultasse da ação das bandeiras a incorporação do território e seria força reconhecer que estas não haviam passado de maltas de homens ferozes, os quais, longe da influência repressiva das leis penais, andaram à solta, praticando nos sertões brasileiros barbaridades horripilantes" 288 .

Esse primeiro momento da história paulista foi visto como seu período áureo, quase mesmo republicano. Nas palavras de Toledo Piza,

"De 1532 até 1720, durante perto de dois séculos, a liberdade individual dos cidadãos republicanos paulistas, o seu espírito de iniciativa e de empreendimentos e o seu gosto pelas aventuras dos sertões desconhecidos tinham-se firmado e desenvolvido em ausência das medidas restritivas de um governo local acanhado, mesquinho e suspeitoso, que ainda não existia; e a ação governamental emanada de Lisboa e do Rio de Janeiro, por falta de uma bem combinada hierarquia administrativa que só mais tarde apareceu, ia perdendo a intensidade de seus efeitos à proporção que se distanciava do seu ponto de partida e quase não se fazia sentir na periferia.

Foi esta época especialmente caracterizada pela extensão da liberdade individual e pela realidade da antonomia municipal e forma por estes motivos o período áureo da história colonial de São Paulo. Fora da influência imediata da ação deletéria do governo colonial, aquelas famosas gerações de audaciosos bandeirantes, de imperterritos sertanejos, não tinham para os seus atos outras restrições e outros incentivos mais de que os estímulos de um brio levado ao extremo, a sua proverbial honradez, o sentimento da sua dignidade individual, a consciência do seu valor pessoal, o gosto cavalheiresco pelas arriscadas aventuras nos misteriosos sertões do interior e a nobre ambição da independência pessoal pela riqueza bem adquirida" 289 .

Tal situação foi alterada apenas com uma intervenção cada vez mais efetiva de Portugal e suas autoridades coloniais. A mudança da capital para o Rio de Janeiro serviria de marco para esse processo. Na visão de muitos historiadores paulistas, em

\footnotetext{
${ }^{288}$ Idem, p. 20.

${ }^{289}$ Idem, pp. 20- 21.
} 
especial aqueles ligados ao IHGSP, uma presença maior da metrópole na região, assim como sua intromissão em seus negócios econômicos, seria nada menos que fruto de ganância lusitana, até então voltada apenas ao nordeste açucareiro. A suposta liberdade dos paulistas teria seu fim em 1721 quando da nomeação de Rodrigo Cesar de Menezes como Capitão General e Governador de São Paulo. A presença do poderio português no início do séc. XIX se fazia sentir, não se importando em melindrar os colonos. Logo da chegada do novo Governador, este mandou executar alguns indivíduos já condenados apenas para servir de exemplo aos demais moradores. Para Caio Prado Jr, este seria o momento da subordinação de São Paulo ao controle português, bem como o estabelecimento de uma estreita dependência para com a metrópole ${ }^{290}$. O poder político, até então centrado nas mãos dos proprietários de terras, foi sendo transferido para a Coroa portuguesa. O exemplo marcante disso foi a perda do poder decisória das Câmaras Municipais, até então, praticamente as únicas estruturas administrativas da colônia (controladas por membros das elites locais, boa parte deles proprietários rurais) ${ }^{291}$.

Diversos volumes dos Documentos interessantes foram dedicados especificamente a esse tema ${ }^{292}$. De acordo com o levantamento cronológico acerca da história administrativa da capitania, realizado por Toledo Piza, até 1709 os territórios que hoje pertencem a São Paulo, Minas Gerais, Goiás, Mato Grosso, Paraná e Santa Catarina pertenciam à capitania do Rio de Janeiro. Por meio de uma carta régia de 23 de novembro de 1709 foi que toda essa região acabou desmembrada, criando-se a capitania de São Paulo.

Como o ouro encontrado em Minas e Goiás faziam de algumas povoações do interior regiões mais ricas que a própria cidade São Paulo, os primeiros governadores preferiram residir em Ouro Preto, fazendo com que São Paulo não chegasse a gozar das regalias de ser capital.

\footnotetext{
${ }^{290}$ PRADO JR, Caio. Evolução política do Brasil colônia e império. São Paulo, Brasiliense, 1989, p. 43.

${ }^{291}$ Para Prado Jr a metrópole mostrou-se passiva diante a elite colonial, dando-lhe carta branca para agirem como entendessem. Por muito tempo os portugueses limitaram-se ao governo geral, mantendo o mínimo necessário para não perder o contato com a colônia.

${ }^{292}$ Tratam-se dos volumes 12 (1895), 13 (1895), 20 (1896), 32 (1901).
} 
O início da fragmentação viria com o desmembramento de Minas Gerais (1721), devido à sua importância político-econômica. Essa primeira fase teria fim em 1748 mediante a supressão da capitania. Nessa ocasião, todas as deliberações administrativas foram transferidas para o Rio de Janeiro ou para a praça de Santos ${ }^{293}$.

Além da postura "autoritária", D. Rodrigo César de Menezes teria sido importante para a capitania por ser o primeiro Capitão General a efetivamente residir em São Paulo (entre 05 de maio de 1721 e 14 de agosto de 1727). Se por um lado foi ele o responsável por reordenar parte dos serviços da nova capitania, também foi dele a iniciativa de organizar toda a documentação existente, na medida em que parcela dos originais encontrava-se em mal estado de conservação ou perdidas de maneira irremediável. Visando melhor cumprir com suas obrigações administrativas, Menezes chegou a solicitar ao vice-rei "cópia das ordens mais modernas que há de haver", por não ter encontrado aqui documento algum. Em carta de 29 de abril de 1722 teria declarado:

“(...) quando saí do Reino procurei ao Secretário de Estado, sem embaraço do pouco tempo que tive, me desse todas as instruções necessárias ao que me respondeu havê-las remetido, e que cá as acharia, o que sucedeu tanto pelo contrário, que nem as mandou, nem os meus antecessores deixaram papel algum, que como faziam a sua assistência nas Minas Gerais, levaram todos consigo, e que no tempo em que demorei no Rio de Janeiro, se não copiassem os que me pareceram preciosos, ficaria sem nenhum, ${ }^{, 294}$.

Alguns dos temas preferidos por Toledo Piza estavam associados ao processo de independência do Brasil. Questões como a aclamação, em 1821, do governo provisório a partir de São Paulo, passando pelo suplício do Chaguinhas ${ }^{295}$, da

\footnotetext{
293 AESP. Documentos interessantes. São Paulo, Casa Eclética, 1901, vol. 32.

294 AESP. Guia do acervo. São Paulo, Imesp, 1997, p. 09.

${ }^{295}$ Francisco José das Chagas era militar do $2^{\circ}$ Batalhão do Regimento de Caçadores, custodiado em Santos. Em 1821 Chaguinhas, como era conhecido, foi preso e acusado de crime de lesa-majestade por participar de uma rebelião contra a Coroa. Após seu julgamento em São Paulo, foi levado ao patíbulo, situado no largo da Forca. Após três tentativas (em todas a corda arrebentara), a população intercedeu pelo condenado, acreditando tratar-se de uma intervenção divina. Alheias aos clamores, as autoridades militares levaram a
} 
bernarda de Francisco Ignácio e os acontecimentos que marcaram o cenário político paulista e brasileiro até o dia do Fico, em 09 de janeiro de 1822, recebiam do Diretor da Repartição especial atenção.

Aqueles que tratavam a bernarda como mera "questão de penacho" assumiam postura contrária à de Toledo Piza, para quem o evento seria fruto de uma conspiração capitaneada por elementos lusitanos retrógrados em oposição ao nacionalismo desmedido encabeçado pelos Andrada. Tratava-se de um grande acontecimento, cujos desdobramentos seriam os responsáveis por levar ao Rio de Janeiro as figuras de José Bonifácio e Martim Francisco. Por intermédio deles é que o Príncipe Regente, e futuro imperador do Brasil, teria vindo a São Paulo na ocasião do episódio das margens do Ipiranga. Desta viagem, além da independência do Brasil, resultou também no encontro de D. Pedro com a futura Marquesa de Santos, D. Maria Domitila de Castro Canto e Melo, que teria tido importante papel na dissolução da Constituinte de 1823.

Todos esses temas foram tratados ao longo dos 43 exemplares dos Documentos interessantes editados por Toledo Piza. Para se ter a dimensão disso, o primeiro volume da série foi dedicado inteiramente ao tema. Tratava-se de levantamento feito por Paulo Valle, na forma de texto, sobre "A 'bernarda' de Francisco Ignácio" (título original do volume). O evento analisado nada mais fora que uma revolta ocorrida em São Paulo (23 de maio de 1822) contra o Governo Provisório e seus desdobramentos, mediante as ações postas em vigor pelo então Príncipe Regente. De acordo com Antonio de Toledo Piza, o levante dizia respeito ao "início da independência em São Paulo" ${ }^{296}$, quando amotinados invadiram a Câmara pedindo a deposição de Martim Francisco e do Brigadeiro Manoel Francisco Jordão, o que foi efetivado. Para Toledo Piza,

termo a condenação utilizando-se de uma "corda" feita em couro. Após seu corpo ter sido retalhado, sua cabeça teria rolado para dentro da capela de Nossa Senhora dos Aflitos, alimentando a crença popular de sua santidade. Para maiores informações ver: SEVCENKO, Nicolau. "Incursões na entropia paulista". In: CAMARGO, Ana Maria de Almeida. São Paulo: uma viagem no tempo. São Paulo, CIEE, 2005; e SANTANA, Nuto. São Paulo histórico: aspectos, lendas e costumes. São Paulo, Departamento de Cultura, 1937, pp. 60- 5.

${ }^{296}$ AESP. Documentos interessantes. São Paulo, Casa Eclética, 1894, vol. 01, p. 03. 
"Francisco Ignácio, nascido em São Paulo, mas filho de portugueses, educado em Portugal e nos hábitos do exército, não tinha essas maneiras flexíveis e insinuantes" atribuídas ao então Capitão General de São Paulo, General João Carlos Augusto Oeynhausen, que o distinguiam e assegurariam "o êxito aos agitadores da opinião pública" ${ }^{" 297}$.

O levante pode ser visto como resultado do embate entre grupos políticos divergentes capitaneados por José Bonifácio e Martim Francisco Ribeiro de Andrada, de um lado, e Francisco Ignácio de Sousa Queirós e João Carlos Augusto de Oeynhausen, de outro, este último presidente da Junta de governo em São Paulo. Ao que tudo indica, o início do levante teria sido marcado pela convocação de Oeynhausen e Francisco Ignácio para dirigirem-se ao Rio de Janeiro, deixando a presidência da Junta para Martim Francisco. Temeroso pelo destino político, Francisco Ignácio e seus aliados impediram a saída de Oeynhausen e demitiram Martim Francisco do cargo de secretário da Fazenda provincial.

A intervenção de José Bonifácio, então ministro do Reino e de Negócios Estrangeiros, foi providencial. Contando com grande prestígio junto a D. Pedro I, conseguiu que esta Junta fosse extinta. Como conseqüência, o próprio Imperador chegou a viajar para São Paulo com o objetivo de acalmar os ânimos. Por ordem imperial Francisco Ignácio foi removido para Santos e uma junta trina de governo foi estabelecida em São Paulo até que uma nova junta provisória tomasse posse (ocorreu em janeiro de 1823). Martim Francisco foi nomeado ministro da Fazenda e todos os envolvidos no movimento foram anistiados ${ }^{298}$.

Na prática, os revoltosos representariam a manutenção de antigos interesses portugueses, desacreditando o Partido Brasileiro, em especial os irmãos Andrada, devido à sua influência no governo ${ }^{299}$. Para Toledo Piza, a saída de paulistas da

\footnotetext{
${ }^{297}$ Idem, p. 07.

${ }^{298}$ Para Maria Beatriz Nizza o evento mostrou-se menos como reflexo do interesse da elite local em romper com Portugal, e mais seu esforço em pôr fim ao despotismo metropolitano, assegurando a centralidade do Império. Para maiores informações, ver: SILVA, Maria Beatriz Nizza da (org.). História de São Paulo colonial. São Paulo, Editora da Unesp, 2009.

${ }^{299}$ Para Toledo Piza, o ódio popular teria sido canalizado contra os irmãos Andrada por serem os mais influentes no Governo Provisório.
} 
província para conter um levante de tropas portuguesas no Rio de Janeiro (12 de janeiro de 1822) teria aberto espaço para o "elemento português e retrogrado" tentar ganhar projeção política na região ${ }^{300}$.

Esta coleção representou um verdadeiro marco nas possibilidades das pesquisas históricas, servindo de espaço tanto para a publicação de cópias de documentos, como ensaios e artigos resultantes de pesquisas temáticas realizadas por diversos colaboradores. Apenas para se ter a dimensão do vínculo profundo existente entre o Arquivo e o IHGSP, vale ressaltar que todo esse primeiro volume foi "reeditado" integralmente no volume 7 da Revista do Instituto Histórico e Geográfico de São Paulo.

Em muitos casos, a seleção de documentos a serem publicados ocorreu fora do acervo da Repartição, exigindo de seu corpo técnico um empenho ainda maior. Dependendo do tema a que o volume era dedicado, pesquisas e reproduções eram feitas junto aos acervos da Biblioteca Nacional, Arquivo Militar, Arquivo do Congresso Federal, IHGB e Arquivo Nacional, sob ordem do próprio governo estadual $^{301}$.

Como o principal intento da série sempre foi o de subsidiar as pesquisas promovidas por acadêmicos da época, auxiliando na formação de uma identidade paulista, todo esse material era disponibilizado irrestritamente, permitindo sua circulação junto a um grupo cada vez mais amplo de leitores. Assim, a própria Repartição acabou por não guardar exemplares das primeiras edições, fosse por descaso, fosse pela grande procura. De acordo com a relação de publicações e impressos sob guarda da $5^{\text {a }}$ Seção da Repartição, realizada em 1908, na coleção de revistas e jornais, não são encontradas as primeiras edições dos Documentos interessantes. No índice publicado na História do arquivo público de São Paulo, os volumes de 01 a 03 guardados na instituição teriam sido publicados em 1895 quando, na prática, eles são do ano anterior. Além disso, os volumes de 08 a 10,

\footnotetext{
${ }^{300}$ AESP. Documentos interessantes. São Paulo, Casa Eclética, 1894, vol. 01, p. 18.

${ }^{301}$ Entre outros, esse foi o caso do vol. 11 dos Documentos interessantes, intitulado "Divisas entre São Paulo e Minas Gerais".
} 
publicados em 1895, aparecem como 1901, o mesmo acontecendo com os volumes 12 e $13^{302}$. Como será tratado oportunamente, a discrepância de datas não pode ser explicada por mero equívoco no preenchimento de dados de tombo. Devido à grande demanda e constantes reimpressões de muitos dos volumes, muito provavelmente a referência quanto ao ano de publicação possa ser entendida meramente como a data registrada em um volume específico (seu ano de publicação), e não o ano em que o volume surgiu.

Se as origens da grandiosidade paulista era o tema preferido da publicação, a construção da imagem do paulista como o bandeirante desbravador, dotado de espírito pioneiro, responsável pela ampliação das fronteiras portuguesas na América, não poderia ser deixada de lado. Nesse sentido, foram reunidos no volume 5 , documentos referentes às tentativas e esforços paulistas em formar uma colônia às margens do rio Iguatemi (fronteira com o Paraguai), região contestada pela Espanha durante a segunda metade do séc. XVIII. Apesar dos esforços paulistas, a colônia foi desarticulada em outubro de 1777 devido ao descaso do Governador Martim Lopes Lobo de Saldanha ${ }^{303}$. De acordo com alguns documentos publicados na coleção, foram enviadas tropas, armamento e munição para essa praça, visando sua defesa. Contudo, mais não pode ser encaminhado devido à falta de equipamentos disponíveis. Apenas para se ter uma idéia, peças de artilharia precisaram ser compradas de embarcações portuguesas custodiadas em Santos e enviadas para a região devido à falta de suprimentos disponíveis ${ }^{304}$.

Tratavam-se de documentos retirados do próprio acervo do Arquivo e seriam "todos os que encontramos (...) sobre as tentativas e esforços feitos na segunda metade do século passado para a fundação de uma colônia paulista nas margens do rio Iguatemi, em território fronteiro ao Paraguai’305.

\footnotetext{
${ }^{302}$ AESP. Histórico do archivo público de São Paulo. Op. Cit., pp. 223- 4. Para maiores informações, ver relação de títulos publicados em Anexo I.

${ }^{303}$ Para Toledo Piza, a região foi alvo de disputas tão acaloradas que somente após a morte de Solano Lopes foi que o Paraguai abriria mão oficialmente do território.

${ }^{304}$ AESP. Documentos interessantes. São Paulo, Casa Eclética, 1901, vol. 33, p. 09.

305 AMARAL, A. B. do. O Departamento do Arquivo. Op. Cit., p. 55.
} 
Com o mesmo teor, outros quatro volumes da série foram organizados, contando sempre com os comentários de Toledo Piza. Para ele

"Tomada e destruída a praça de Iguatemi, que tanto dinheiro, tanto dinheiro, tantas vidas e tantas lágrimas custou ao povo paulista, dispersado o resto da população que tinha escapado das deserções e das epidemias, o padre Ramos Louzada, que, como comandante da praça, tinha assinado a capitulação (...) trouxe de lá para cá consigo como relíquia dois curiosos objetos que ainda existem e que podem ser vistos em Itu, pelos amantes de raridades históricas: estes objetos são um sino e um crucifixo"306.

O tema mostrou-se recorrente, mesmo quando um livro não era produzido especificamente para esse fim. Em muitos volumes dos Documentos interessantes foram incorporados ofícios, relatórios, bandos ${ }^{307}$, provisões, escolhidos especificamente pelo teor das informações que traziam registradas. No volume 33 (“Bandos, ordens e portarias de D. Luiz Antonio de Souza", de 1901) pode ser lida uma carta enviada por Francisco Carneiro Lobo ao Secretário de Estado em 1769, narrando os constantes ataques indígenas na região do rio Tibagi que, na procura por ferramentas, acabavam matando muitos escravos ${ }^{308}$. Dedicada à criação de gado e alguns faisqueiros, a ordem foi garantida nas margens desse rio apenas com o uso da força militar. A retirada do aparato militar da região, por mando do então Governador interino do Rio de Janeiro, possibilitou ações ainda mais violentas por parte dos nativos.

Na visão de alguns observadores da época, os indígenas teriam verdadeira capacidade de organização militar. Sob o toque de uma gaita disparavam setas,

\footnotetext{
${ }^{306}$ AESP. Documentos interessantes. São Paulo, Casa Eclética, 1895, vol. 09, p. 161. De acordo com a análise de Toledo Piza, o sino teria sido fundido pelos jesuítas e levado a São Paulo por Antonio Raposo após ataque paulista à missão em 1632.

307 Tratava-se de um aviso público referente a ordens ou decretos governamentais a serem divulgados.

${ }^{308}$ Este rio pertence à bacia do Paranapanema, tendo seu curso no atual estado do Paraná. No séc. XVIII, por se tratar de uma região "fronteiriça", o governo português custodiado em São Paulo pouco fez, de maneira efetiva, para preservar os colonos que para lá se deslocaram. A falta de apoio era tamanha que nesta carta de 18 de maio de 1769, Francisco Lobo descreve que "parece se não pode presumir se não de milagre de Nossa Sra. da Penha, a quem tinham recorrido, e não de forças humanas poderem se defender de tanta multidão tão poucos". AESP. Documentos interessantes. São Paulo, Casa Eclética, 1901, vol. 33, p. 07.
} 
"e com jeitos de corpo os faziam subitamente lançar por terra ao tempo que se disparavam as armas para se livrarem dos danos delas, conservando-os em um contínuo e veloz movimento de balanço dos corpos, já para um lado, já para outro e já prostrados, e a todos os movimentos disparando cargas de setas" 309 .

Outro assunto que suscitava acalorados debates dizia respeito à formação física da Província/ Estado de São Paulo. Este tema foi tratado no volume 11 da coleção, um dos mais "famosos" da série. Tal adjetivação pode ser feita devido ao volume de reimpressões ocorridas desse material. Originalmente contando com 1.000 exemplares, foram comuns os pedidos de verba por parte de Toledo Piza e outros diretores junto à Secretaria do Interior na intenção de efetuar pagamento por novas tiragens da obra ${ }^{310}$. Esse material acabava sendo distribuído para bibliotecas, escolas e órgãos administrativos, no intuito de melhor instruir servidores públicos, historiadores e futuras gerações quanto a grandeza de São Paulo. Em declaração oficial, o geólogo estadunidense Orville Adelbert Derby diria:

“(...) aceitei o convite do digno diretor do Arquivo do Estado, Dr. Antonio de Toledo Piza, para colecionar e coordenar tudo que fosse possível encontrar referente a este assunto. Cabeme o grato dever de agradecer ao dito diretor e ao pessoal do Arquivo a seu cargo o eficaz auxílio que me prestaram na execução desta tarefa, a qual, na sua parte material, é quase exclusivamente obra do amanuense da Comissão Geográfica e Geológica, Dr. Melquíades da Boa Morte Trigueiro, que com admirável paciência e perspicácia conseguiu decifrar quase por inteiro diversos documentos que, à primeira vista, pareciam totalmente perdidos pela ação destruidora do tempo. Alguns documentos que faltavam no Arquivo do Estado foram obtidos, por cópia, na Biblioteca Nacional, Instituto Histórico, Arquivo Público, Arquivo Militar e Arquivo do Congresso Federal do Rio de Janeiro, graças à

\footnotetext{
${ }^{309}$ Idem, p. 05.

${ }^{310}$ Em ofício de 25 de julho de 1895, Toledo Piza solicitou ao Secretário do Interior Interino, João Álvares Rubião Jr., dinheiro para pagamento de 6.000 mapas, cartas e plantas anexas aos Documentos interessantes vol. XI. Acervo AESP. Repartição de Estatística e Arquivo (correspondências), E 01436 (folha 89v). Aparentemente, devido aos elevados gastos com impressão, fossem de publicações ou mapas estatísticos a serem preenchidos, em 21 de dezembro de 1899 o então Secretário do Interior comunicava em ofício $\mathrm{n}^{\circ} 1.461$ que todos os trabalhos de impressão deveriam ser efetuados nas oficinas do Diário Oficial do Estado. Acervo AESP. Repartição de Estatística e Arquivo (protocolo de correspondências), E 01433 (p. 126).
} 
gentileza dos diretores destes estabelecimentos e aos patrióticos esforços do digno paulista, Barão Homem de Melo",311.

Por meio dele, Derby, membro da Comissão Geográfica e Geológica de São Paulo $^{312}$, elencou documentos referentes à questão de limites entre São Paulo e Minas Gerais, servindo para reconstruir a história de diferentes localidades, bem como o "desenvolvimento geográfico de uma parte do território nacional" 313.

Sob seu comando a Comissão iniciou seus trabalhos por meio de exploração dos rios Itapetininga, Paranapanema e afluentes, levando em conta, entre outras coisas, sua navegabilidade. Para Luiz Augusto Costa

"Está portanto posto aqui claramente qual o real objetivo vislumbrado para a CGGSP: reconhecer o território para melhor infraestruturá-lo e por conseqüência imediata, explorá-lo. Em outras palavras, planejamento territorial" ${ }^{314}$.

Na opinião do autor, existiria uma discrepância entre o espírito cientificista de Derby e o pragmatismo econômico dos dirigentes paulistas. Para Silvia Mendonça Figueirôa, o fato de em 1905 o "sertão" (aproximadamente 1/3 de todo o território paulista) ainda não ter sido mapeado, gerava grande desconforto junto ao governo, na medida em que inviabilizava sua efetiva ocupação e exploração ${ }^{315}$. "Com a saída de Derby, a Comissão adquire um caráter mais pragmático, com uma produção

\footnotetext{
${ }^{311}$ AESP. Documentos interessantes. São Paulo, Casa Eclética, 1896, vol. 11, p. XXXII.

312 Tratou-se de uma comissão criada por iniciativa de Antonio Carlos de Arruda Botelho, o Visconde do Pinhal, e do Presidente da Província, o Conselheiro João Alfredo Corrêa de Oliveira, ainda durante o Império. Instituída pela lei provincial $\mathrm{n}^{\circ}$ 9, de 27 de março de 1886, nos mesmos moldes da Comissão Geológica Brasileira (criada em 1875 e extinta dois anos depois) era chefiada por Derby, e tinha o intuito de atender às novas demandas impostas pela cafeicultura. Criada para o estudo do solo e rios de São Paulo, assim como sua flora e fauna, atuou até 1931. Foi a responsável pela organização das primeiras coleções zoológicas da então província, fosse por meio de prospecções próprias ou compra. A Comissão atuou antes mesmo da implantação do Museu Paulista, que tinha à frente de seus serviços o zoólogo alemão Hermann Von Ihering. Para maiores informações, ver o Capítulo I dessa dissertação.

${ }^{313}$ AESP. Documentos interessantes. São Paulo, Casa Eclética, 1896, vol. 11, p. XXXI.

${ }^{314}$ COSTA, Luiz Augusto Maia. O ideário urbano paulista na virada do século. O engenheiro Theodoro Sampaio a as questões territoriais e urbanas modernas (1886-1903). São Paulo, Dissertação de Mestrado defendida na Faculdade de Arquitetura e Urbanismo da Universidade de São Paulo, 2001, p. 172.

315 FIGUEIRÔA, Silvia Fernanda de Mendonça. Os modernos bandeirantes: a Comissão Geográfica e Geológica de São Paulo e a exploração científica do território paulista (1886-1931). São Paulo, Dissertação de Mestrado defendida no Departamento de História da Faculdade de Filosofia, Letras e Ciências Humanas da Universidade de São Paulo, 1987.
} 
intensa e profícua"316. É importante ressaltar que um dos grandes nomes vindos dessa Comissão foi o de Teodoro Sampaio, cujas idéias eram manifestadas em artigos publicados pelo IHGSP. Em seus trabalhos, ele deixava de lado os supostos mecanismos para a construção de uma identidade nacional, optando pela elaboração de um projeto que possibilitasse o desenvolvimento econômico e social do país ${ }^{317}$.

Todo esse espírito cientificista imposto à Comissão, pelo menos em seus primeiros anos (1886-1905) exigiu de Orville Derby, assim como de toda a sua equipe, um grande trabalho de compilação e sistematização de informações. Parte desses esforços foram registrados nos Documentos interessantes, tratando-se de uma coletânea feita a partir de um levantamento ocorrido três anos antes, junto a diversos acervos arquivísticos. Apesar de acreditar que toda a documentação pública existente em São Paulo, e boa parte da mineira, acerca do tema ter sido aí compilada, seu organizador abria a possibilidade de que outros documentos pudessem ser localizados na medida em que parte significativa de material sobre o tema poderia estar nas mãos de "colecionadores de papéis velhos". Além disso, um volume apreciável poderia ter desaparecido "pela ação do tempo",318.

Como no início do séc. XX a questão de limites e fronteiras nacionais ainda suscitavam dúvidas, Toledo Piza incumbiu parte da equipe técnica da Repartição para que efetuassem trabalhos de levantamento de documentos referentes aos limites do Brasil com a Argentina. Todo o material selecionado foi devidamente copiado e enviado a uma Comissão especial, criada exclusivamente para dirimir esta questão. Em relatório de 1895, Piza afirmava que tal material serviria para demonstrar as reações enérgicas de São Paulo quando das invasões de territórios promovidos pelos argentinos, e que estes não poderiam alegar "aquiescência (...), nem mesmo o silêncio negligente" ${ }^{\text {319. }}$.

\footnotetext{
${ }^{316}$ COSTA, L. A. M. O ideário urbano. Op. Cit., p. 173.

317 Teodoro Sampaio desligou-se da Comissão em 1892, indo chefiar a Repartição de Água e Esgoto de São Paulo. Para maiores informações sobre o tema ver: COSTA, L. A. M. O ideário urbano paulista. Op. Cit.

${ }^{318}$ AESP. Documentos interessantes. São Paulo, Casa Eclética, 1896, vol. 11, p. XXXIII.

319 GOVERNO DE SÃO PAULO. Relatório da Secretaria dos Negócios do Interior. São Paulo, Tipografia Vandorden, 1895, p. 57.
} 
$\mathrm{Na}$ visão de Toledo Piza, o "valioso material do arquivo não deveria permanecer segregado dos estudiosos" ${ }^{320}$. Isso talvez tenha norteado parte de seus esforços no sentido de compilar e publicar as cópias dos documentos sem seguir um critério cronológico rígido visto que a brevidade era exigida pelo adiantado estado de deterioração dos originais $^{321}$. Este foi o caso do volume 19, dedicado às correspondências do Capitão General D. Luiz Antonio de Souza. Nele existem notas afirmando ter sido o material publicado pois o livro de registros onde se encontravam as anotações originais encontrava-se em péssimas condições de conservação, especialmente pela ação da água e traças ${ }^{322}$. O mesmo aconteceu no primeiro documento publicado no volume 23 , referente às correspondências do Capitão General Antonio Manoel de Mello Castro e Mendonça, entre 1797 e 1800. Trata-se de uma carta remetida ao Conde de Oeiras, em cuja nota explicativa escrita por Toledo Piza pode ser lido:

"Esta interessante carta está estragadíssima por água e traças; é com a aplicação de reagentes químicos que conseguimos ler alguma coisa e por meio de interpolações de palavras que podemos completar os pensamentos. Outros documentos, adiante nesse mesmo livro, estão ainda em pior estado, e o próprio papel, apodrecido pela água e pelo tempo desfaz-se todo em uma massa informe com a aplicação de reagentes $" 323$.

Como muitas vezes os documentos transcritos encontravam-se em péssimas condições de conservação, foi necessário a adoção de técnicas de leitura paleográfica. De acordo com palavras do próprio Diretor, em nota explicativa na mesma carta ao Conde de Oeiras,

"As palavras sublinhadas são as restauradas por meios químicos e por interpolações aconselhadas pelo sentido da

\footnotetext{
${ }^{320}$ AMARAL, A. B do. O Departamento do Arquivo. Op. Cit., p. 57.

${ }^{321}$ Nas palavras de Barreto do Amaral, a respeito do estado de conservação de parcela dos documentos, "muitos deles [encontravam-se] deteriorados pela ação deletéria da umidade, que empastava maços de tal forma que tornava quase que impossível separarem-se as folhas sem totalmente inutilizá-los". Ibidem. (p. 57)

${ }^{322}$ Aparentemente, os registros tiveram início no documento de $\mathrm{n}^{\circ} 14$ por erro de quem confeccionou os originais (informações anteriores encontram-se dispersos pelo volume).

${ }^{323}$ AESP. Documentos interessantes. São Paulo, Casa Eclética, 1896, vol. 23, p. 01.
} 
oração e os pontinhos representam a parte totalmente destruída do manuscrito" ${ }^{324}$.

O mesmo ocorreu no volume 29 ("Correspondência do Capitão General Antonio Manoel de Mello Castro e Mendonça”, entre os anos de 1797- 1800). Contudo, no caso específico desse volume, pela falta de documento melhor, organizadores encartaram dois pedidos de doação para rocio $(1860$ e 1724, respectivamente), devido à inexistência de um documento qualquer que pudesse comprovar a doação de terras feito por Martim Affonso, fosse no arquivo da Repartição, fosse no arquivo da Câmara Municipal paulista.

Um elemento significativo que aponta para o papel impactante dessa coleção no cenário intelectual paulista é a tiragem que cada um dos volumes atingia. Originalmente, as primeiras edições contaram com a impressão de 1.000 exemplares. Contudo uma análise mais atenta na correspondência da Repartição para com a Secretaria do Interior é possível constatar que muitos deles, devido à procura, acabaram sendo reimpressos. Em diversos ofícios, Toledo Piza solicita verba junto à Secretaria do Interior com o intuito de pagar pela reimpressão de exemplares dos Documentos interessantes. Aparentemente, tais pedidos foram sendo atendidos, sendo comuns os volumes que podem ter atingido cifras superiores a 2.500 exemplares $^{325}$. Para se ter a dimensão de como esses livros assumiram importante papel junto à intelectualidade local, tornando-se de uso recorrente, em relatório assinado por Adolpho B. de Abreu Sampaio, então Diretor do Arquivo, em 1926, pode ser lido o pedido por reimpressões de muitos exemplares dos Documentos interessantes pois encontravam-se esgotados ${ }^{326}$.

Como foi dito, muitas das transcrições nada mais eram que o esforço de preservação de originais danificados pela água, com folhas desfazendo-se, e que nas

\footnotetext{
${ }^{324}$ Idem, p. 02.

${ }^{325}$ Apesar das dificuldades em mensurar a efetivação de tais pedidos, cabe um esclarecimento. Em muitos desses ofícios o Diretor da Repartição solicita verba para quitar dívidas previamente contraídas junto a casas editoriais. Para maiores informações vale a leitura das minutas de ofícios registrados em material encadernado Repartição de Estatística e Arquivo (correspondências), E 01434, acervo AESP.

${ }^{326}$ Acervo AESP. Repartição de Estatística e Arquivo (relatórios), E 12033.
} 
palavras de Piza, não obedeciam à "ação restauradora dos ácidos"327. Em outros casos, como no volume 40, como parte da "Correspondência do Conde de Sarzedas" encontrava-se danificada pela água e traças, foram agregadas notas explicativas a esse respeito. Assim, visando garantir preservação e acesso ao material, parte da documentação referente ao governo do Conde de Sarzedas já havia sido publicada em outros volumes da série ${ }^{328}$.

Isso talvez ajude a entender o porquê de em 1901 terem sido publicados 5 volumes da série (de 31 a 35) referentes a períodos anteriores ao recorte cronológico adotado para os volumes 29 e 30. Nesses dois últimos casos, tratavam-se de "Correspondência do Capitão General Antonio Manoel de Mello Castro e Mendonça”, entre os anos de 1797 e 1802, enquanto que os 5 volumes posteriores percorrem o período de 1721 a $1775^{329}$. Vale salientar que logo no volume seguinte, o de número 36, podem ser encontradas "Correspondência do Governo Geral" referentes aos anos de 1815 a $1822^{330}$.

Ainda no final do séc. XIX foi dada prioridade à publicação de cartas régias e correspondências de capitães generais, entre eles D. Luiz Antonio de Souza Botelho Mourão. Tratava-se de material referente à administração colonial do séc. XVIII. A publicação de cartas patente (volume 26, "Patentes, provisões e sesmarias") ganhou certa atenção pois representava material de grande relevância histórica por ser ele capaz de registrar tanto a biografia como a "fé de ofício do agraciado", conforme registrado pelo próprio Toledo Piza em nota ${ }^{331}$.

Quanto a isso, alguns pontos merecem ser destacados. Além de Piza colocarse como agente atuante na seleção, transcrição e publicação de boa parte dos documentos, mesmo que transparecendo neutralidade, cabia a ele a confecção de

\footnotetext{
${ }^{327}$ AESP. Documentos interessantes. São Paulo, Casa Eclética, 1901, vol. 35, p. 01.

${ }^{328}$ Trata-se do volume 22 (1896), intitulado "Bandos, regimentos e ordens dos Capitães Generais Conde de Sarzedas e D. Luiz Mascarenhas" (1732- 1748).

${ }^{329}$ Os títulos atribuídos a esses volumes são, respectivamente: "Diversos", "Correspondências e papéis avulsos de Rodrigo Cesar de Menezes", entre 1721- 1728; "Bandos, ordens e portarias de D. Luiz Antonio de Souza" (1721- 1775); e 2 referentes a "Correspondência do Capitão General D. Luiz Antonio de Souza" (1770- 1771, 1772-1775).

${ }^{330}$ Para maiores informações ver Anexo I.

${ }^{331}$ AESP. Documentos interessantes. São Paulo, Casa Eclética, 1898, vol. 26, p. 05.
} 
"breves" anotações que pudessem orientar a leitura dos documentos, sejam eles de maneira isolada ou em conjunto. Para muitos, entre eles Armando Prado, isso talvez tenha sido um de seus maiores "defeitos" como historiador. Em muitos casos o Diretor tratava com entusiasmo desmedido determinados vultos políticos, atuando com "paixão no julgá-los e uma certa fúria agressiva no defendê-los" ${ }^{, 32}$. Exemplo disso é seu posicionamento diante da participação dos irmãos Andrada na independência do país, criticando todos aqueles que, como João Carlos de Oeynhausen e o padre Diogo Feijó, não mostravam simpatia por eles. Na opinião de Armando Prado, tentando enaltecer seus nomes "pelo processo de fazer vácuo ao redor deles, restringiu a quase nada o papel de Pedro I", reivindicando a José Bonifácio "a primazia e as glorias do Fico"333.

Em muitos casos tratam-se de meras anotações explicativas quanto a locais, nomes e distâncias ${ }^{334}$. Em outros, o editor dá-se ao luxo de analisar as "mentiras" registradas nos documentos. Apenas para utilizar como exemplo, no volume 20, dedicado à "Correspondência interna do Governador Rodrigo Cezar de Menezes (1721-1728)", foi transcrita a carta enviada ao Vice Rei relatando minuciosamente as providências que foram dadas para a perseguição e captura dos irmãos Leme. Em nota, o Diretor afirma que "grande parte desta história é pura invenção do Capitão General". Desde datas e nomes, além da precisão dos fatos, são questionados. Até mesmo a distância, em léguas, entre São Paulo e a cidade de Itu é motivo de questionamento (seriam 18 léguas e não 36, como afirma Cesar de Menezes). Além de autoritário, Toledo Piza vê o Capitão General como um sujeito dado a invencionices. Que os irmãos Leme eram "maus homens" ele não questiona, mas teriam sido vítimas de uma "infame traição da parte do Capitão General"335.

Desconstruindo a fala do Governador de São Paulo, Piza afirma:

\footnotetext{
${ }^{332}$ PRADO, A. “Antonio de Toledo Piza”. Op. Cit., p. 22.

${ }^{333}$ Ibidem.

${ }^{334}$ Isso ocorreu em uma nota explicativa feita por Toledo Piza no volume 23 da coleção. Tratava-se de uma correção quanto a distância de São Paulo a Sorocaba, visto que as "léguas brasileiras eram de 6.600 metros". AESP. Documentos interessantes. São Paulo, Casa Eclética, 1896, vol. 23, p. 04.

335 AESP. Documentos interessantes. São Paulo, Casa Eclética, 1896, vol. 20, p. 82.
} 
"Quem ler esta história há de supor que Rodrigo César esteve presente à ação quando ele deixou-se ficar em São Paulo e não foi a Itu e Porto Feliz, onde os fatos se passaram. Quem comandava a força era o ouvidor Godinho Manço, tendo a seu lado o gatuno Sebastião do Rego, que se apropriou dos bens das vítimas..."336

Na visão crítica de Toledo Piza, caberia a Cesar de Menezes apenas o envio de ordens e bandos, enquanto toda a ação ficava a cargo de Godinho e Rego. Para tanto, o Diretor cotejava a leitura dos documentos a serem transcritos e publicados nos Documentos interessantes à luz de outras leituras, muitas delas também transcritas no decorrer da coleção. Em uma nota explicativa apensa a esta mesma carta endereçada ao Vice-rei, o Diretor mesclava alguns de seus comentários a outros documentos, remetendo o leitor a eles ${ }^{337}$.

Em outras ocasiões, o juízo de valor feito por Toledo Piza direciona a compreensão dos documentos. Em sua visão, a ação despótica e violenta do governo colonial foi a responsável pela dispersão de parte dos colonos pelo sertão pois "todos desejavam estar o mais longe possível das garras do governo", preferindo lutar com as feras dos sertões. Ao descrever um habitante do sertão, Luiz Antonio de Souza Botelho Mourão diz ser ele um sujeito fugidio e assustado "que nem o chapéu lhe tira, e se lhe dizem a mínima palavra desconfia, e mata logo". Para Toledo Piza, tratava-se de uma afirmativa exagerada por parte do Governador, mas caso fosse verdade, o leitor poderia fazer uma idéia "do que era o governo colonial que reduziu o seu povo a este estado de selvageria!"338.

Por meio de suas explicações é possível perceber uma certa visão de mundo que, além de conduzir para uma leitura "correta" dos documentos, também explica,

\footnotetext{
${ }^{336}$ Idem, p. 83.

${ }^{337}$ Neste caso, Toledo Piza orienta o leitor a procurar o volume 12 da coleção, além do anexo B do volume 13. Idem, p. 85.

338 Trata-se de uma carta enviada ao Conde de Oeiras, contendo considerações gerais sobre os costumes e lavoura de São Paulo, bem como informações sobre seus habitantes. AESP. Documentos interessantes. São Paulo, Casa Eclética, 1896, vol. 23, p. 05.
} 
aos olhos da ciência mais moderna, alguns dos dilemas enfrentados pelos colonos paulistas. Em uma de suas notas é possível ler:

"Até hoje ainda nos sertões se emprega este método de derrubada de mato virgem para a plantação de milho e criação de porcos; para a plantação de café o trabalho precisa ser mais cuidadoso a fim de haver simetria na plantação em carreiras" ${ }^{339}$.

Na seqüência, outra explicação sobre agricultura é feita: "aqui não se diz alqueires de que mantimento; mas deve ser de milho, porque a derrubada da mata virgem só se faz para a plantação de milho" 340 .

Como a maioria dos capitães generais atendiam quase que exclusivamente as vontades e determinações portuguesas, a análise de suas condutas tornou-se um dos principais focos de Toledo Piza. Ao analisar documentos produzidos por Botelho Mourão, o Diretor aponta para sua falta de percepção quanto à realidade do sertão. Em nota ele aponta

"A lógica do Capitão General é um tanto falha, porque considera somente um lado da questão social e econômica. A principal dificuldade da lavoura estava na sua improficuidade; os produtos do solo não tinham saída e quando sobrava dos gastos domésticos apodrecia nos paióis. Se as sobras haviam de apodrecer nos armazéns era melhor que ficassem apodrecendo nas roças, porque havia economia do custo da colheita. As expedições que precisavam de mantimentos eram raras e não valia a pena guardar mantimentos na fiúza delas. Não havia estradas, nem ligação com a Europa, e Portugal só queria ouro e mais ouro" 341 .

Tratava-se da visão de um administrador português que via o colono como preguiçoso e ineficiente, e que solto à própria sorte ficaria rude e desrespeitoso. E aí residiria o erro pois, deste tipo sertanejo teria surgido o bandeirante paulista, desbravador, e detentor de um passado glorioso.

\footnotetext{
339 AESP. Documentos interessantes. São Paulo, Casa Eclética, 1896, vol. 20, p. 06.

${ }^{340}$ Ibidem.

${ }^{341}$ Idem, p. 08.
} 
Como boa parte dos documentos reproduzidos nos Documentos interessantes foram confeccionados visando atender a uma demanda administrativa, muitas das informações aí registradas acabavam servindo como verdadeiras prestações de conta da administração colonial aos superiores metropolitanos. Um interessante exemplo disso diz respeito a um ofício endereçado ao Conde de Oeiras, remetido por Luiz Antonio de Souza Botelho Mourão, sobre a remessa de artilharia e suprimentos para a região do Iguatemi. Em determinado momento, o Capitão General vangloria-se de tudo ter feito em prol dos moradores da região do Iguatemi sem que fossem onerados os cofres públicos ou a Real Fazenda, além de tudo ter sido feito sem que a população manifestasse a "menor queixa".

Em nota, Toledo Piza apontou tratar-se de verdadeiro engodo, visto que

“(..) para poupar a fazenda real se submetia o povo a trabalhos públicos forçados, e o governador dava-se por feliz deste seu ato não trazer revoltas!

As queixas não chegavam aos seus ouvidos e quando chegassem não seriam transmitidas ao Marques de Pombal; a grande questão era fazer o serviço sem despesa para a real fazenda",342.

Ao analisar determinados documentos, Toledo Piza expõe parte de seus valores acerca de algumas personalidades políticas de São Paulo. Quanto à administração de Martim Lopes Lobo de Saldanha, a exposição de suas opiniões é gritante, especialmente quanto ao caráter "hipócrita" do Capitão General. Em carta de 10 de junho de 1775 ele rogava para que Sua Majestade não viesse a saber das confusões ocorridas na administração de D. Luiz Antonio de Souza "para que the não sejam funestas as conseqüências". Na opinião de Toledo Piza,

"Esta linguagem mostra o quanto era hipócrita o Capitão General de São Paulo. Levou ele todos os sete anos de seu governo a denunciar D. Luiz Antonio ao governo de Lisboa e a caluniar o seu antecessor e, entretanto, diz que deseja que o rei saiba das minúcias do governo anterior" ${ }^{\text {,343 }}$.

\footnotetext{
${ }^{342}$ AESP. Documentos interessantes. São Paulo, Casa Eclética, 1901, vol. 33, p. 10.

${ }^{343}$ AESP. Documentos interessantes. São Paulo, Casa Eclética, 1903, vol. 42, p. 19.
} 
Para Barreto do Amaral, a morte de Antonio Toledo Piza (1905), teria posto fim ao "ciclo áureo das publicações do Arquivo, que enriqueceu a historiografia paulista com uma soberba quantidade de peças, quase todas elas inéditas" ${ }^{\text {344 }}$. Os dois últimos volumes da série publicados por ele (os de números 42 e 43) referentes a correspondências do Capitão General Martim Lopes Lobo de Saldanha datam do ano de 1903. Por 12 anos calaram-se os Documentos interessantes para a história e costumes de São Paulo, apesar de algumas iniciativas no sentido de preservá-lo ${ }^{345}$. Na prática, o retorno ocorreu apenas em 1915 com a edição de um volume que o próprio Toledo Piza havia deixado preparado ${ }^{346}$.

${ }^{344}$ AMARAL, A. B do. O Departamento do Arquivo. Op. Cit., p. 58.

345 Em relatório de 1907, o então Diretor da Repartição solicitava autorização para dar continuidade à publicação dos Documentos interessantes. Apesar do Secretário do Interior apoiar a medida, em sua resposta encaminhava para "que se peça ao Poder Legislativo verba para tal fim, visto tratar-se de publicação de real utilidade". Relatório da Secretaria dos Negócios do Interior, 1907- 8, p. 41.

${ }^{346}$ Trata-se do volume 44, intitulado "Diversos". 


\section{Capítulo 3}

\section{Os arquivos e seus dilemas: memória, patrimônio e representações}

\section{1- Relações entre a memória e a constituição do patrimônio}

Sabidamente, história não é sinônimo de memória, apesar de o senso comum ter alimentado durante as últimas décadas a proximidade, quase sinonímica, de termos como memória, passado, história e patrimônio ${ }^{347}$. Apesar das diferenças, tais conceitos apresentam proximidades significativas, sendo possível construir um sentido de passado somente por meio da reflexão consciente do homem sobre sua memória. Assim, a memória atuaria de maneira inquestionável na ordenação e releitura de vestígios pretéritos, atuando como agente na construção de narrativas projetadas a partir de lembranças ${ }^{348}$. Nas palavras de Eclea Bosi,

"Na maior parte das vezes, lembrar não é reviver, mas refazer, reconstruir, repensar, com imagens e idéias de hoje, as experiências do passado. A memória não é sonho, é trabalho. Se assim é, deve-se duvidar da sobrevivência do passado, 'tal como foi', e que se daria no inconsciente de cada sujeito. A lembrança é uma imagem construída pelos materiais que estão, agora, à nossa disposição, no conjunto de representações que povoam nossa consciência atual. Por mais nítida que nos pareça a lembrança de um fato antigo, ela não é a mesma imagem que experimentamos na infância, porque nós não somos os mesmos de então e porque nossa percepção alterou-se e, com ela, nossas idéias, nossos juízos de realidade e de valor. $\mathrm{O}$ simples fato de lembrar o passado, no presente, exclui a identidade entre as imagens de um e de outro, e propõe a sua diferença em termos de ponto de vista"${ }^{349}$.

\footnotetext{
${ }^{347}$ PAOLI, Maria Célia. "Memória, história e cidadania: o direito ao passado". In: DEPARTAMENTO DO PATRIMÔNIO HISTÓRICO. O direito à memória: patrimônio histórico e cidadania. São Paulo, DPH, 1992. ${ }^{348}$ Mediante a diversidade de possibilidades, seria impossível imaginar a história como algo preexistente ao historiador. Na prática, essa diversidade de elementos permitiria sua constante modificação e rearticulação conforme a posição social que o indivíduo ocupasse no seu meio, bem como as diferentes relações estabelecidas com diferentes grupos.

${ }^{349}$ BOSI, Eclea. Memória e sociedade. São Paulo, Companhia das Letras, 1994, p. 55.
} 
Para Jacques Le Goff, a preocupação acadêmica com o tema da memória é oriunda da chamada "história das mentalidades", propagada a partir dos anos 1970. Os primeiros estudos pautavam-se na tentativa de análise das diferentes manipulações sofridas por um fenômeno histórico no campo da memória. Em sua opinião, Philippe Áries teria sido um dos pioneiros ao defender que o historiador deveria dedicar maior atenção ao papel exercido por monumentos e comemorações junto ao seio de um determinado grupo, relacionando-os a personagens políticas reconhecidas, com atuação especial no campo da formação dos Estados-Nação.

$\mathrm{Na}$ opinião de Carlos Alberto Vesentini o passado colocar-se-ia sempre no presente, projetando sua força. Com isso, mesmo diante de um conhecimento cada vez maior sobre eventos ocorridos sua interpretação não escaparia às amarras estabelecidas pelos vencedores. Assim, por mecanismos de "transubstanciação uma enorme gama de significados pode ser colocada aos episódios de um dia, de um mês, convertidos em fato histórico", ausentando-se, convenientemente, a criação política $^{350}$.

Citando o historiador Maurice Halbwachs, Le Goff apontou que a memória individual existiria sempre a partir de um fenômeno coletivo, posto que todas as lembranças seriam constituídas no interior de um determinado grupo social. Tais elementos seriam responsáveis pelo estabelecimento de certa identidade na medida em que a existência, ou construção, de um passado comum representaria o compartilhamento de memórias, além da coletivização de experiências. Indo além, Vesentini afirma que o ato de recordar poderia transparecer e tomar rumos de uma memória coletiva, confundindo-se com a posição de observador privilegiado (ocular) que esteve presente em um evento escolhido como fundamental pela posteridade, a partir de seleções e determinação de sentido ${ }^{351}$. O passado refeito pela memória legitimaria o poder vigente e definiria o campo de ação coletiva.

\footnotetext{
${ }^{350}$ VESENTINI, Carlos Alberto. A teia do fato. São Paulo, Hucitec, 1997, p. 26.

${ }^{351}$ Idem, p. 35.
} 
Assim, a memória constituiria o suporte fundamental dessa identidade, refletindo a maneira como os diferentes agentes sociais organizam e traduzem, para os demais, seus diferentes mecanismos de reconhecimento, podendo ao mesmo tempo constituir um registro de fatos ou um mosaico de lembranças ${ }^{352}$. Em termos orgânicos, ela permitiria "ao homem atualizar impressões ou informações passadas, ou que ele representa como passadas" ${ }^{, 353}$.

Uma manifestação importante desse fenômeno estaria vinculada ao desenvolvimento da noção de tradição, especialmente após a instalação das estruturas nacionais. Fruto de uma intervenção direta das classes dominantes, serviria como forma de legitimação do poder, sendo muitas delas inventadas no presente, apesar da aparência, compondo um substrato capaz de garantir a superioridade inatacável de alguns povos, em uma clara manifestação conservadora. No limite, a idéia de tradição estaria amparada na transmissão, por gerações, de práticas ou valores determinados, compondo o conjunto das crenças de um povo.

O estabelecimento de certos valores e práticas seriam inculcados mediante repetição, constituindo-se como verdadeira “continuidade em relação ao passado"354, mesmo que de maneira artificial, em oposição às constantes mudanças propostas pelo mundo moderno e a tentativa de consolidação imutável de alguns aspectos do vivido $^{355}$. Assim,

"consideramos que a invenção de tradições é essencialmente um processo de formalização e ritualização, caracterizado por referir-se ao passado, mesmo que apenas pela imposição da repetição" ${ }^{, 356}$.

\footnotetext{
${ }^{352}$ LE GOFF, Jacques. História e memória. Campinas, Editora da Unicamp, 2003.

${ }^{353}$ Idem, p. 366.

${ }^{354}$ HOBSBAWM, Eric. "Introdução: a invenção das tradições". In: HOBSBAWM, Eric; RANGER, Terence (org.). A invenção das tradições. Rio de Janeiro, Paz e Terra, 1997, p. 09.

${ }^{355}$ Na visão de Hobsbawm não se deveria confundir tradição com convenção ou rotina. Esses dois últimos, apesar de sugerirem o imutável, não possuem nenhuma função simbólica ou ritual. Para o autor, a automatização das convenções, visando sua maior eficiência, acabaria por inibir sua capacidade de lidar com imprevistos.

${ }^{356}$ HOBSBAWM, E. "Introdução". Op. Cit., p. 12.
} 
Ao analisar a constituição das tradições como um fenômeno inventado, Hobsbawm apontou para a possibilidade de, no caso de instituições recentes, sem antecessores históricos ou mesmo um passado capaz de trazer legitimidade, os mecanismos utilizados para consolidá-las teriam que se inventar quanto à continuidade, especialmente estabelecendo-se um certo espírito de ancestralidade mediante a consolidação de símbolos e acessórios inteiramente novos. Este talvez tenha sido o caso da figura do bandeirante, ou mesmo do pioneirismo paulista, enaltecidos nos artigos publicados na Revista do IHGSP, amparados por documentos preservados e disponibilizados pela Repartição de Estatística e Arquivo e seus Documentos interessantes. Na prática, tais "tradições inventadas" tolheriam aquilo que de essencial tem a história, qual seja, seu caráter vivo e dinâmico.

Utilizando-se de premissas semelhantes àquelas estabelecidas por Vesentini ao analisar a revolução Constitucionalista de 1932, seria possível identificar o movimento bandeirante como um fato/ marco, excluindo-se diversas possibilidades de identificação dos possíveis. Assim, perder-se-ia

a "percepção do processo como choque entre sujeitos e propostas divergentes e como sequência de cristalizações também diferentes, como que se esvai - sendo substituída pelo movimento de um tempo e de algumas ações a confluírem para um único lugar" ${ }^{357}$.

Para Hobsbawm seria possível classificar as tradições em três categorias distintas: 1) aquelas que estabelecem ou simbolizam coesão social ou condições de admissão de um grupo; 2) aquelas que estabelecem ou legitimam instituições, status ou relações de autoridade; 3 ) e aquelas cujo propósito seria a socialização de idéias, valores e padrões de comportamento. $\mathrm{O}$ caso paulista talvez possa ser enquadrado em todos esses elementos. Quanto ao primeiro item, levando-se em conta o seu pioneirismo em relação ao movimento republicano, por exemplo, associado ao desenvolvimento econômico da região e o elevado volume de imigrantes europeus, nada mais necessário que a implantação de uma identidade coesa capaz de legitimar

${ }^{357}$ VESENTINI, C. A. A teia do fato. Op. Cit., 138. 
o poder de São Paulo diante aos demais estados da federação. Levando-se em conta que o republicanismo ainda não fora estabelecido de maneira homogênea e coerente em todo o país, com uma proposta verdadeiramente nacional, nada mais importante que legitimar a liderança dos membros do PRP (Partido Republicano Paulista) por meio de uma ancestralidade "inventada" em termos históricos ${ }^{358}$. Nesse sentido, o passado serviria para corroborar o presente, garantindo tanto a liderança política paulista como a coesão regional em torno de um ideal "patriótico" e nacionalista ${ }^{359}$.

Dessa mesma forma, instituições foram sendo legitimadas, consolidando-se relações de autoridade. O pioneirismo paulista, em moldes semelhantes ao estadunidense, divulgados sob a ótica de um novo modelo de ensino, refletiria esse fenômeno, consolidando o poder republicano nas mãos das "boas e ilustres" famílias tradicionais de São Paulo, moradoras do bairro de Higienópolis, em detrimento de agentes sociais "perniciosos" como negros, brancos pobres, imigrantes ${ }^{360}$.

Para Oliveira Vianna a superioridade paulista seria fruto da permanência eugênica do grupo, persistindo características "mentais dos antigos paulistas nos paulistas modernos" ${ }^{361}$, sendo que pouco, ou nada, havia modificado no caráter desse grupo durante seus quatro séculos de evolução, tais como o senso prático, o realismo, espírito de idealista, a ambição, a intuição econômica, além de audácia, obstinação, perseverança, tenacidade, gosto pela realização e "capacidade varonil de tomar absolutamente a sério todas as empresas em que se metem" ${ }^{\text {362 }}$. Essa persistência teria se constituído como uma característica devido à necessidade de sobrevivência, estabelecendo-se semelhanças entre os paulistas e os estadunidenses, especialmente quanto às grandes empreitadas. Em suma, as diferenças atribuídas a São Paulo em relação ao restante do país estabeleciam-se, na visão de Vianna, em

\footnotetext{
${ }^{358}$ Apesar dos ideais republicanos se fazerem presentes em São Paulo desde a década de 1870, o Manifesto Republicano assinado na cidade do Rio de Janeiro (1870) precedeu o surgimento do próprio Partido (no caso paulista, o PRP foi criado em 1873, durante a Convenção de Itu). Sua extinção ocorreu apenas em 1937, como decorrência da implantação do Estado Novo (1937-45).

${ }^{359}$ Para maiores informações, ver Capítulo I.

${ }^{360}$ Esse talvez fosse o campo de atuação tanto da Escola Normal como do Museu Paulista, ambos com forte caráter pedagógico no tocante à difusão desses novos ideais. Para maiores informações, ver Capítulo I.

${ }^{361}$ VIANNA, Francisco José de Oliveira. Ensaios inéditos. Campinas, Unicamp, 1991, p. 69.

${ }^{362}$ Idem, p. 70.
} 
parte pelas maiores possibilidades econômicas da região, mas também pela excelência eugênica da "velha cepa ancestral".

O surgimento de instituições como a Repartição de Estatística e Arquivo, o IHGSP, o Museu Paulista e a Escola Normal estariam associados à necessidade de se criar mecanismos eficientes para a "socialização de idéias, valores e padrões de comportamento". É importante lembrar que os diversos volumes da série Documentos interessantes eram distribuídos por todo o estado, ou mesmo fora do país, fossem com o intuito de subsidiar pesquisas locais amparadas em documentos oficiais, fosse para garantir a boa formação de professores e alunos espalhados nos diversos Ginásios públicos no estado, ou mesmo como ferramenta de propaganda. Além disso, os próprios membros do IHGSP seriam encarregados de estabelecerem uma visão oficial da história regional, amparada em documentos, que serviria de subsídio a uma história nacional. Vale lembrar que a própria escolha do local onde o Museu Paulista foi construído teve forte caráter monumental, atuando como elemento pedagógico, responsável por divulgar um determinado conjunto de valores e normas comportamentais.

Com tudo isso, seria possível estabelecer uma ligação profunda entre uma determinada memória, paulatinamente construída, e um caráter específico de história como parte componente do conjunto ideológico e de saberes de uma nação, na medida em que ela seria convertida em ferramenta responsável por selecionar, escrever, popularizar e institucionalizar aquilo que deveria ser preservado, independentemente de como foram mantidos na memória popular. Com isso,

“as ações modernas, com toda a sua parafernália, geralmente afirmam ser o oposto do novo, ou seja estar enraizadas na mais remota antiguidade, e o oposto do construído, ou seja, ser comunidades humanas, 'naturais' o bastante para não necessitarem de definições que não a defesa dos próprios interesses" 363 .

${ }^{363}$ HOBSBAWM, E. “Introdução”. Op. Cit., p. 22. 
Ao analisar a obra de Alison Landsberg, Ulpiano Bezerra de Meneses apontou para a importância de uma "nova" modalidade de memória, chamada de "memória protética". Em sua opinião, seria semelhante ao que ocorreria por intermédio da indústria cultural, produzindo-se algo alheio ao sujeito, não sendo reflexo de seus usos e práticas, não havendo "apropriação, por experiência, de um passado alheiro, mas uma seleção e apropriação das memórias em oferta"364.

Sendo assim, esses elementos acabariam por atuar no sentido de ressaltar aquilo que deveria ser guardado na memória ou mesmo esquecido, tornando-se uma preocupação significativa para os grupos dominantes de sociedades históricas. Le Goff observou que "os esquecimentos e os silêncios da história são reveladores desses mecanismos de manipulação da memória coletiva"365, tornando-se manifestações de perda, voluntária ou não, da memória de povos e nações, em uma clara demonstração de alteração na identidade do grupo. Apenas para exemplificar, durante a chamada Idade Média, característica de parcela significativa da Europa ocidental, foi comum a criação dos libri memoriallis, tratando daquilo que estava destinado a ser lembrado ou esquecido.

Nas palavras de Pierre Nora, o processo de aceleração da história seria responsável pelo estilhaçamento da memória. Para ele, as sociedades tecnológicas não poderiam ser responsabilizadas por estabelecer uma crise na própria história, mas sim junto à consolidação da memória, valorizada na sua ausência.

Levando-se em conta a idéia de Le Goff de que uma memória étnica poderia ser encontrada nos mitos de origem, seria possível enquadrar o caso do habitante de São Paulo dos séc. XVII- XVIII, travestido de desbravador bandeirante, nesse mecanismo interpretativo. Em muitos casos, como no próprio exemplo, tende-se a confundir história com mito, promovendo verdadeira exumação e "ressurreição" dos "bravos heróis".

\footnotetext{
${ }^{364}$ MENESES, Ulpiano T. Bezerra de. "Cultura política e lugares de memória”. In: AZEVEDO, Cecília (org.) et al. Cultura política, memória e historiografia. Rio de Janeiro, FGV, 2009, p. 451.

${ }^{365}$ LE GOFF, J. História e memoria... Op. Cit, p. 367.
} 
Associado a este fenômeno estaria o surgimento da figura de homensmemória, verdadeiros narradores responsáveis por serem seus fiéis depositários, sendo deles a atribuição de manter a coesão do grupo. Talvez este fosse o caso tanto dos historiadores ligados ao IHGSP como da própria Repartição de Arquivo, responsável por aglutinar em seus acervos, assim como disponibilizar, uma infinidade de documentos referentes ao período embrionário da grandeza bandeirante. Além disso, a seleção de documentos tidos como interessantes nada mais seria que uma clara demonstração das escolhas feitas por um determinado grupo sobre qual memória deveria ser preservada, permitindo a construção de uma versão histórica específica ${ }^{366}$.

O surgimento da São Paulo "moderna" (conforme apresentado no Capítulo I), com todos os seus conflitos e múltiplos agentes sociais, exigia o estabelecimento de um foco central capaz de orientar narrativas sobre o passado, levando determinados feitos à fronteira onde uma memória passaria a ser considerada como a "verdadeira" história. Assim, uma memória coletivizada foi sendo sobreposta às memórias individuais (especialmente devido ao grande volume de imigrantes e homens pobres nesse centro urbano), permitindo a "conquista" de um passado coletivo por todos esses diferentes agentes. Vale salientar que o interesse aqui não seria o de destruir a individualidade, mas sim, transformá-la, dando-lhe outra coerência e sentido.

Em sua análise sobre o papel do documento na confecção da história, Elias Saliba argumentou que em algumas comunidades africanas, cujo tempo verbal no passado inexiste, um morto permaneceria vivo na memória até que o último que o conheceu morresse (um morto-vivo). Esse seria o caso dos suaites, cabendo aos

\footnotetext{
${ }^{366}$ Para Le Goff, teria sido com o advento da escrita que o estabelecimento de uma "memória artificial" tornou-se possível, relacionada diretamente a uma nova organização de poder. Assim surgiram os arquivos, calcados nos aspectos da durabilidade e publicidade, mesclando tanto uma função administrativa como a de garantidor de poder. $\mathrm{O}$ surgimento suportes documentais diferenciados permitiria um melhor armazenamento e a transmissão de informações pelo tempo/ espaço, possibilitando reordenar, retificar e examinar frases e até palavras de uma peça específica.
} 
anciãos carregar "o registro do que passou de mais importante", tornando-se "historiadores necromantes do passado" 367.

Outro elemento que merece destaque nessa análise diz respeito ao vínculo existente entre aquilo que se quer preservar na memória e o estabelecimento de instituições escolares e currículos responsáveis por divulgá-las, articulando-se uma tradição oral à lógica imperialista da escrita. Talvez essa fosse a função de instituições como a Escola Normal, situada na praça da República, no centro da capital paulista. A formação de professoras dedicadas às primeiras letras serviria tanto como elemento garantidor de eleitores num Brasil "moderno" e republicano ${ }^{368}$, como reprodutoras de um modelo específico de poder. Se Marc Ferro tiver razão, o uso dos livros didáticos auxiliaria no estabelecimento de um controle social sobre o passado, construindo-o de maneira uniforme ${ }^{369}$. Para tanto, seria necessário a criação de leitores (público escolar), divulgadores (professores) e agentes produtores de saber (no caso paulista, os historiadores do IHGSP espalhados por todo o estado, amparados nos documentos oficiais da Repartição de Arquivo e seus Documentos interessantes). Vesentini chegou a afirmar que o livro didático (primeira ferramenta com que se toma contato com a história), tende a universalizar leitores diferentes, colocando-se elementos definidos e prontos como saberes corretos. Assim, desapareceriam conflitos e divergências, estabelecendo-se o conhecimento como algo unitário e impositivo ${ }^{370}$.

Em sociedades ágrafas, pessoas encarregadas de preservar a memória, especialmente quanto a temas religiosos e questões jurídicas, tornavam-se importantes. No caso helênico, exemplo de sociedade que vivenciou o hibridismo quanto ao letramento, pois a palavra falada continuava a ser de grande importância,

\footnotetext{
367 SALIBA, Elias Thomé. "Pequena história dos documentos: aventuras modernas e desventuras pósmodernas". In: PINSKY, Carla Bassanezi e LUCA, Tania Regina de. O historiador e suas fontes. SP, Contexto, 2009, p. 311.

${ }^{368}$ A Constituição republicana de 1891, em seu artigo 70, estabelecia que seriam considerados eleitores todos aqueles que, maiores de 21 anos, não fossem analfabetos, mendigos, praças de pré ou religiosos de qualquer ordem que, uma vez vinculados, tivessem que renunciar à liberdade individual em nome da obediência.

${ }^{369}$ FERRO, Marc. A manipulação da história no ensino e nos meios de comunicação. São Paulo, Ibrasa, 1983.

${ }^{370}$ VESENTINI, C. A. A teia do fato. Op. Cit., 68.
} 
a figura do aedo nada mais seria que a de um cantor responsável por popularizar acontecimentos míticos e heróicos ${ }^{371}$. Com o fortalecimento da escrita como forma de mediar o registro e a comunicação do grupo, estes indivíduos foram sendo substituídos por arquivistas, especialmente devido ao poder e "arrogância" da palavra escrita sobre a palavra falada.

A França pós revolucionária assistiu uma retomada no culto da memória aos mortos, com monumentos, ritos e visitações a cemitérios ${ }^{372}$. Comemorar tornou-se elemento importante no programa revolucionário, inclusive pela Constituição de 1791. De acordo com ela, seriam "estabelecidas festas nacionais para conservar a recordação da Revolução Francesa"373. Vale lembrar que a multiplicação de datas comemorativas veio especialmente após a laicização dessas festas e do próprio calendário, com forte atuação de mecanismos de censura. Apenas para exemplificar, foi no primeiro ano de mandato de George Washington na presidência dos Estados Unidos que o feriado do Thanksgiving foi estabelecido, em uma clara alusão às origens coloniais, sendo este o primeiro feriado nacional dos EUA ${ }^{374}$.

A utilização desses eventos como forma de comemoração permitiu aos grupos conservadores fazerem uso da memória como objeto e instrumento de governo, em uma verdadeira celebração "política" do passado, utilizando-se de objetos comemorativos especialmente elaborados para esse fim, como era o caso de selos, moedas, medalhas, placas... Para Le Goff, a memória exterior, registrada por meio da escrita, teria dado um grande salto após o surgimento dos dicionários e enciclopédias, ainda durante o séc. XVIII.

\footnotetext{
${ }^{371}$ Daí viria a importância das musas, filhas da deusa Mnemosine com Zeus. Cada uma das nove divindades seria responsável pela inspiração poética, possibilitando a certos homens lembrar-se do passado para transmiti-lo aos meros mortais.

${ }^{372}$ De acordo com Le Goff, os cemitérios ligaram-se à memória especialmente com o advento do romantismo. Para P. Joutard os mártires nacionais foram acomodados em cemitérios destinados a eles. Em sua opinião, o caso mais famoso nos Estados Unidos seria o cemitério de Arlington, "à entrada de Washington, transformado em símbolo da unidade nacional após acolher os confederados sulistas mortos depois todos os mortos nas guerras seguintes e, de modo geral, os antigos combatentes". JOUTARD, Philippe. "Memória e identidade nacional: o exemplo dos Estados Unidos e da França". In: AZEVEDO, Cecília (org.) et al. Cultura política, memória e historiografia. Rio de Janeiro, FGV, 2009, p. 73.

${ }^{373}$ LE GOFF, J. História e memoria. Op. Cit., p. 399.

${ }^{374}$ JOUTARD, P. “Memória e identidade nacional”. Op. Cit., p. 61.
} 
Com o desenvolvimento científico do séc. XIX, inúmeros vocábulos foram criados fazendo alusão à memória, num reflexo claro de que esta questão passara a fazer parte do cotidiano, especialmente europeu, alargando-se a memória coletiva.

Como disciplina científica, a história surgiu nesse mesmo contexto, sendo o documento escrito a pedra fundamental sobre a qual se estabeleceu toda a base para o julgamento promovido por parte do historiador. Privilegiando-se esse tipo de documento, tornou-se possível a reconstrução de grandes movimentos políticos articulados por grupos dominantes, banindo aqueles que mais tarde seriam considerados oprimidos ou minoritários, além de descartar temas relativos ao cotidiano e às mentalidades.

O historiador passou a alimentar um verdadeiro fetiche em relação ao documento (fonte primária), atribuindo a ele o poder de tornar visível, no presente, um determinado passado real ofuscado ${ }^{375}$. Para Keith Jenkins o problema residiria no fato de o evento passar a ter, ilusoriamente, a mesma clareza no presente do que teve para um observador de sua época ${ }^{376}$.

Sendo assim, boa parte da discussão sobre o que é documento histórico teria por intuito "estabelecer qual a memória que deve ser preservada pela História e qual o estudo da própria História"377. Para Saliba, os trabalhos de Lucien Febvre acabavam "com a ilusão da existência do documento isolado, bruto, quase imponderável, relacionando-o à participação ativa, rigorosa e seletiva do historiador" ${ }^{\prime 378}$. Assim, o documento deixaria de ser visto como resto de uma determinada manifestação pretérita, passando a ser encarado como seu produto.

Na opinião de Vesentini, "seria muito difícil admitir isenção quando se pensa no poder, especialmente quando sua intenção explícita é a afirmação de sua

\footnotetext{
${ }^{375}$ Apesar da busca pela autenticidade e veracidade ser comumente atribuída aos "positivistas" do séc. XIX, tal preocupação pode ser encontrada no ambiente cartesiano da segunda metade do séc. XVII. Por meio desse novo processo investigativo, o texto passou a ter a função de convencer, e as notas de rodapé, provar. SALIBA, E. T. "Pequena história dos documentos". Op. Cit., p. 314.

${ }^{376}$ JENKINS, Keith. A história repensada. São Paulo, Contexto, 2004.

377 KARNAL, Leandro; TATSCH, Flavia Galli. "Documento e história: a memória evanescente". In: PINSKY, Carla Bassanezi e LUCA, Tania Regina de. O historiador e suas fontes. SP, Contexto, 2009, pp. 09- 10.

${ }^{378}$ SALIBA, E. T. "Pequena história dos documentos". Op. Cit., p. 317.
} 
legitimidade" ${ }^{\text {379 }}$. Para ele, os diferentes documentos produzidos no exercício administrativo expressariam práticas políticas em litígio, fruto da existência de sujeitos históricos divergentes e atuantes ${ }^{380}$.

Se por um lado, seria possível afirmar que toda valoração feita ao documento é dada pelo pesquisador, numa construção permanente, estabelecendo-se diálogo constante entre o presente e o próprio documento (ao olhar do analista, um mesmo documento pode encontrar "novos nichos semânticos"381), por outro, tal posicionamento relegaria a um segundo plano toda a intencionalidade existente antes mesmo de seu ato constitutivo, ignorando toda uma série de disputas presentes no campo das relações sociais. Para Ulpiano Bezerra de Meneses
"nenhum atributo de sentido é imanente. O fetichismo consiste, precisamente, no deslocamento de sentidos das relações sociais- onde eles são efetivamente gerados- para os artefatos, criando-se a ilusão de sua autonomia e naturalidade. Por certo, tais atributos são historicamente selecionados e mobilizados pelas sociedades e grupos nas operações de produção, circulação e consumo de sentido" ${ }^{382}$.

Como afirmou Meneses, em um mundo individualista, determinados vestígios do passado funcionariam como vínculos de qualificação social, sujeitos a transformações de sentidos. Sendo assim, tais elementos possuiriam uma biografia (trajetória), sendo necessário avaliá-los nas diferentes modalidades de apropriação de que fazem parte, entendendo-os mediante sua interação social. No caso específico dos documentos, eles não apresentariam, intrinsecamente, uma identidade, mesmo que provisoriamente indispensável. De acordo com suas palavras, caberia aos "ósculos metodológicos do historiador resgate a Bela Adormecida de seu sono programático. É pois a questão do conhecimento que cria o sistema documental. O historiador não faz o documento falar: é o historiador quem

\footnotetext{
${ }^{379}$ VESENTINI, C. A. A teia do fato. Op. Cit., 130.

${ }^{380}$ Idem, p. 93. Para esse historiador, as disputas políticas continuariam interferindo no "fato" por meio das interpretações, buscando projetar-se na memória em verdadeiras versões herdadas de tempos anteriores.

${ }^{381}$ KARNAL, L.; TATSCH, F. G. "Documento e história". Op. Cit., p. 13.

${ }^{382}$ MENESES, Ulpiano T. Bezerra de. "Memória e cultura material: documentos pessoais no espaço público". In: Estudos históricos. Rio de Janeiro, vol. 11, nº 21, 1998, p. 91.
} 
fala e a explicitação de seus critérios e procedimentos é fundamental para definir o alcance de sua fala" ${ }^{383}$.

Mediante o argumento de que as diferentes manifestações histórico-culturais de um povo não seriam capazes de retratar um fato em si, mas sim sua reapresentação, seja sob a forma de teatro ou simulação, os arquivos passariam a desempenhar um papel importante nesse cenário, visto que seus acervos acabariam recebendo importância patrimonial, como algo intocado, que teria chegado até o presente com o intuito de fazer os homens conhecerem seu verdadeiro passado. Nestor Canclini defende a idéia de que

a "teatralização do patrimônio é o esforço para simular que há uma origem, uma substância fundadora, em relação à qual deveríamos atuar hoje. Essa é a prática das políticas culturais autoritárias" $^{, 384}$.

De acordo com Antonio Augusto Arantes, tal preocupação com a preservação estaria diretamente vinculada ao "desejo de manter laços de continuidade com o passado", sendo "pensada como trabalho transformador e seletivo de reconstrução e destruição do passado, que é realizado no presente e nos termos do presente" ${ }^{\text {, }} 85$.

Foi diante desses elementos que a idéia de patrimônio veio sendo alimentada, sempre calcada em escolhas, muitas delas utilizando-se de critérios duvidosos. Fraçoise Choay demonstrou de maneira elucidativa a ação de preservação do patrimônio arquitetônico referente a Roma, promovida durante séc. XV, por ordem do papado. Contudo, a mesma Igreja que protegeu com uma das mãos, destruiu com a outra. Boa parte do mármore e das pedras dos monumentos pagãos foram retirados de seus locais de origem, destruídos (transformados em cal) e reutilizados na construção da "nova" Roma renascentista, dotada de forte caráter cristão ${ }^{386}$.

\footnotetext{
383 Idem, p. 95.

${ }^{384}$ CANCLINI, Néstor Garcia. Culturas híbridas. São Paulo, Edusp, 2006.

385 ARANTES, Antonio Augusto. Produzindo o passado. Estratégias de construção do patrimônio cultural. São Paulo, Brasiliense, 1984, pp. 08- 09.

${ }^{386}$ CHOAY, Françoise. A alegoria do patrimônio. São Paulo, Estação Liberdade/ Editora da Unesp, 2001.
} 
Philippe Joutard, ao analisar o vínculo existente entre memória e identidade nacional, levou em conta o caso francês e o estadunidense. De acordo com suas palavras,

\begin{abstract}
"a França, que bem cedo, desde o século XIII, fundou sua identidade numa memória histórica bastante elaborada, que a partir daí só fez se fortalecer, em especial durante as crises, a Guerra dos Cem Anos, e, sobretudo, durante as guerras religiosas. De outro lado, uma nação recente, de história mais curta: os Estados Unidos (...) que desenvolveu um forte centralismo e uma unidade que desconfia dos particularismos, e um poder federal que delega o máximo de função aos estados"387.
\end{abstract}

Dentro dessa perspectiva, o culto aos heróis opunha-se ao espírito republicano estadunidense. Tanto assim, que em 1812 "não se hesitou em destruir a casa de Benjamin Franklin na Filadélfia”, e quatro anos mais tarde quase foi demolido o Independence Hall, local "onde foi assinada em 1776 a Declaração de Independência" ${ }^{388}$.

O conceito de patrimônio, estabelecido e difundido durante o séc. XIX, tornou-se gradativamente um campo de saber próprio aos especialistas do passado. Em uma noção tradicional e popular esses elementos resumir-se-iam quase exclusivamente à arquitetura e às artes plásticas de grande vulto (monumentos e estátuas), numa falsa idéia de que seriam recebidos do passado como algo a ser preservado, restaurado e difundido devido a um suposto valor inquestionável, mediado por um consenso coletivo, não trazendo consigo supostas divisões sociais ou étnicas. Preservado por motivos estéticos e/ ou gloriosos, um monumento seria dotado de uma aparente isenção ${ }^{389}$.

\footnotetext{
${ }^{387}$ JOUTARD, P. "Memória e identidade nacional". Op. Cit., p. 59.

${ }^{388}$ Idem, p. 60. Isso não significou dizer que mais tarde novos monumentos fossem erigidos, como foi o caso da própria cidade de Washington, toda ela construída em estilo neoclássico.

${ }^{389}$ Este é o caso brasileiro que, em um primeiro momento, a idéia de patrimônio esteve atrelada a exemplares arquitetônicos a serem preservados (haja vista a criação do SPHAN, em 1937). Vale lembrar que nesse contexto a história gozava de certo prestígio quanto ao papel desempenhado na formação da identidade nacional, mesmo que dedicado ao controle e docilização. Para maiores informações ver: MARTINS, Ana Luiza. "Fontes para o patrimônio cultural: uma construção permanente". In: PINSKY, Carla Bassanezi e LUCA, Tania Regina de. O historiador e suas fontes. SP, Contexto, 2009.
} 
Desde esse momento a idéia de patrimônio cultural vem sendo consolidada como conjunto de bens representativos da ação humana, deixados de herança por um determinado grupo, demonstrando o envolvimento da comunidade local com um conjunto de bens culturais, reflexo de uma relação específica com a noção de tempo, construindo certa identidade. Assim, desfrutar do patrimônio seria incorporar naturalmente algo do qual o indivíduo já é um herdeiro, sendo proibido a ele "desertar" de seu destino. Nas palavras de Pierre Bourdieu seria a forma com que o indivíduo deveria "transformar-se no que é", e o reduto patrimonial poderia tornarse o elemento de lembranças de nós mesmos no futuro ${ }^{390}$. Por isso que para Joutard, sem a presença do Estado "não há articulação entre memória e identidade nacional" ${ }^{\prime 391}$.

Maria Célia Paoli apontou para uma faceta do debate que mereceria melhor atenção, qual seja, a relação do público com o próprio patrimônio. Tal questão mostra-se importante na medida em que o conceito de patrimônio consolidou-se na perspectiva de "uma imagem congelada do passado". Assim, a necessária preservação simbólica e material de determinados elementos ficaria distanciada de seu caráter coletivo, deixando de expressar um conjunto de experiências sociais orgânicas ${ }^{392}$, silenciando ou escondendo outras possibilidades narrativas. A história seria concebida "como um processo acabado e fechado aos significados sociais"393. Ao mesmo tempo, uma determinada identificação com o "vencedor" passaria a ser alimentada, mesmo que com isso fossem geradas suas contradições ${ }^{394}$.

Não foi por acaso que o próprio conceito de patrimônio estabelecido pelo Decreto-Lei no 25 de 1937, responsável por criar o SPHAN (Serviço do Patrimônio Histórico e Artístico Nacional), vinculava-se a tudo aquilo que fosse visto como

\footnotetext{
${ }^{390}$ CHOAY, F. A alegoria do patrimônio. Op. Cit.

${ }^{391}$ JOUTARD, P. "Memória e identidade nacional". Op. Cit., p. 60.

${ }^{392}$ PAOLI, M. C. "Memória, história e cidadania". Op. Cit., p. 25.

${ }^{393}$ Ibidem.

${ }^{394}$ Para a autora seria esse exercício o responsável por estabelecer aquilo que comumente é conhecido por "história oficial", preservando apenas alguns testemunhos específicos. Idem, p. 26.
} 
excepcional, ou estivesse ligado a pessoas ilustres, buscando desvendar as "manifestações genuínas do país"395.

Se uma das questões fundamentais desse debate relaciona-se ao forte vínculo mantido pela idéia de patrimônio com a consolidação de uma memória, bem como seu diálogo constante entre passado e presente, os critérios adotados comumente no ato de seleção acabam por privilegiar objetos inerentes à classe dominante, levando a uma visão distorcida da memória coletiva, especialmente pela falta de uma representatividade mais ampla. Apesar da aparência formal globalizante, esses bens não pertenceriam a todos, passando a ser vistos como elementos de produção de valor, identidade e distinção de setores hegemônicos modernos, produzindo uma herança cultural assimilada de maneira diferente e desigual por grupos sociais distintos.

Ao analisar o desenvolvimento urbano de São Paulo, Nicolau Sevcenko apontava para a contínua expansão da fronteira de investimentos imobiliários, ocorrida na cidade desde o séc. XIX, estabelecendo constantemente novos bolsões de "modernidade". Em sua opinião, a rua que melhor tipificaria esse processo seria a rua São Paulo, originalmente chamada rua dos Ingleses, situada no atual bairro da Liberdade. Para ele, o que permitiria a constituição de seu caráter identitário seria

"seu potencial de polarização de recursos, centralidade
orgânica, articulação de fluxos, referência espacial,
simbolização e visibilidade. Ou seja, o que define o seu papel
e identidade é a sua condição, ao mesmo tempo, de núcleo da
cidade-centrífuga, de vitrine da cidade-mercadoria, de
passarela da cidade-desfile, de palco da cidade-espetáculo e
de pódio da cidade-poder"396.

Contudo, sua própria escolha não apresentaria expressamente nenhum desses elementos, sendo muitas vezes taxada como um verdadeiro espaço maldito, recebendo e acolhendo tudo aquilo que a cidade rejeitava, dando-lhe novo

\footnotetext{
${ }^{395}$ MARTINS, A. L. "Fontes para o patrimônio cultural”. Op. Cit., pp. 285- 6.

396 SEVCENKO, Nicolau. "Incursões na entropia paulista". In: CAMARGO, Ana Maria de Almeida. São Paulo: uma viagem no tempo. São Paulo, CIEE, 2005, p. 187.
} 
significado. Daí sua relevância, pois permitiria a compreensão não daquilo que ela mostra diretamente, mas sim, o que esconde e releva em seus "desvãos, espaços e presenças que são como resíduos varridos para debaixo do tapete vistoso da paisagem urbana" ${ }^{397}$, tornando-se verdadeiro contraponto daquilo que se pretendeu construir como elemento identitário.

Todos os elementos que não representassem o novo ambiente construído pelas elites, entendam-se os (i)migrante, negros e mestiços, deveriam ser escondidos no cenário de progresso pretendido por esse grupo. Assim,

“A aversão das novas elites em relação aos rios, às várzeas e à natureza e exuberante da Piratiniga, área sagrada para os índios e atraente para os negros e seus descendentes, secretou um pendor deletério das camadas dirigentes para estabelecer os referenciais da cidade na sua própria área construída, nos portentos da engenharia, nas dinâmicas dos fluxos de mercadorias, finanças e comunicações, nos processos de valorização cumulativa pela concentração de riquezas, nos nichos de segregação social e assepsia ambiental"398.

Sendo assim, um posicionamento aparentemente "neutro" diante o passado, que defendesse a preservação de tudo aquilo que é antigo, também esconderia uma postura ideológica muito evidente. A preservação da totalidade do fazer humano amparava-se na mesma premissa da destruição, que é a de não reconhecer e valorizar o significado coletivo do passado. Na opinião de Paoli,

o “'antigo' parece estar apenas no sentido de perda- e o critério de preservação dos documentos, objetos e monumentos, constitui uma forma de nostalgia de algo que não existe mais" ${ }^{399}$.

$\mathrm{Na}$ modernidade, certos saberes e objetos tornaram-se superiores por terem sido produzidos por grupos dominantes ou porque esses elementos possuiam “informação e formação necessárias para compreendê-los e apreciá-los, quer dizer,

\footnotetext{
${ }^{397}$ Ibidem. Sobre esse aspecto, ver também Capítulo I.

${ }^{398}$ Idem, p. 195.

${ }^{399}$ PAOLI, M. C. "Memória, história e cidadania”. Op. Cit., p. 26.
} 
para controlá-los melhor" ${ }^{\natural 00}$. Sendo assim, para Eunice Ribeiro Duham o censo comum não estaria de todo errado ao tachar certos bens culturais como "melhores" que outros, pois na medida em que a elite possui dinheiro, tempo (inclusive para lazer) e treinamento, acabaria produzindo e se apropriando de bens culturais mais elaborados.

Com isso, setores dominantes determinariam quais os bens superiores e como deveriam ser preservados. A "mundialização dos valores e das referências ocidentais contribuiu para a expansão ecumênica das práticas patrimoniais" ${ }^{\text {"401 }}$, podendo gerar falsa consciência, recusa do real ou mesmo repetição.

Os monumentos, vistos como manifestações de um momento ou lembrança, conforme o próprio termo latino, passaram a ser utilizados como elementos de rememoração, tornando-se a materialidade de uma identidade nacional, com forte caráter afetivo, atuando sobre a memória e a identidade de grupos, significando, desde o séc. XVIII, poder, grandeza e beleza.

$\mathrm{Na}$ contemporaneidade, por meio de uma ação direta da mídia e meios de comunicação, potencialmente tudo poderia ser convertido em monumento, ou mesmo "patrimônio" ${ }^{\text {402 }}$. Exemplos desse poder tornaram-se visíveis nos casos mais comuns. Talvez isso tenha ocorrido com a cidade de Búzios, no litoral carioca. Nos anos 1950, a atriz Brigitte Bardot visitava a região da Cote-d'Azur (especificamente a cidade de Saint-Tropez) quando decidiu viajar para o Brasil. Durante sua estada, acabou hospedando-se em uma aldeia de pescadores no litoral carioca. Essa região transformou-se em um dos grandes focos turísticos do país, acarretando em especulação imobiliária e interesse pela preservação do local, apesar da "expulsão" dos antigos moradores.

Associado a toda essa questão de patrimonialização encontram-se os debates e mecanismos vinculados aos processos de tombamento. Na maioria dos casos, ele

\footnotetext{
${ }^{400}$ CANCLINI, N. G. Culturas híbridas. Op. Cit.

${ }^{401}$ CHOAY, F. A alegoria do patrimônio. Op. Cit., p. 207.

${ }^{402}$ Conforme já citado, para a ampliação desse debate valeria a leitura da obra A manipulação da história, de Marc Ferro.
} 
acarreta uma forma de sacralização da memória, relacionada a conceitos e critérios elitistas, correndo-se o grande risco de se proteger a coisa em si e não seu significado histórico-cultural ${ }^{403}$.

Por meio desse mecanismo os museus tornariam-se verdadeiras pontes entre tempos, espaços, indivíduos, grupos sociais e culturas diferentes, num simulacro de infinitudes, fazendo alusão à própria abrangência do patrimônio nacional, como se esta instituição fosse capaz de abarcá-la, construindo uma suposta legitimidade em torno de si, apesar de sacar os objetos dos meios ou idéias que lhes davam vida. Na prática, tal atitude transformou os museus, e mesmo as coleções particulares, em verdadeiros cemitérios, cujas peças seriam resignificadas ao bel prazer do colecionador, sem atentar-se para os motivos sociais, políticos e culturais de sua criação. Além disso, a preservação e proliferação de monumentos passou a produzir uma invisibilidade, e não mais a presença do passado ${ }^{404}$.

A origem disso também poderia ser remontada à Inglaterra do séc. XVIII ou ao período revolucionário francês, quando esses estabelecimentos passaram a ter a função de instruir a nação, transferindo os bens móveis a locais definitivos e abertos ao público, sobrepondo-se o nacional ao regional. Com isso, tornaram-se verdadeiros espaços de renovação de uma hegemonia cultural ${ }^{405}$. Aparentemente, foi em torno dessa valorização que teriam surgido tanto os museus como os arquivos públicos, ambos responsáveis por estabelecerem elementos subsidiários à construção

\footnotetext{
${ }^{403}$ Vale lembrar que foi somente a partir da década de 1980 que Instituto do Patrimônio Histórico e Artístico Nacional (IPHAN) passou a considerar como patrimônio os bens de origem popular, afazeres e festas, danças, procissões, gastronomia (cultura imaterial), deixando de lado o exclusivismo das estruturas arquitetônicas.

${ }^{404}$ MENESES, U. T. B. de. "Cultura política”. Op. Cit., p. 455.

${ }^{405}$ A noção de um museu estatal surgiu mediante a fusão de interesses públicos e privados, dando início à valorização da arte a partir dos monumentos. Esse foi o caso do Museu Britânico, "inaugurado" com o acervo do médico escocês Hans Sloane (1753). Em ata, o Parlamento inglês expressava sua determinação em convergir esse acervo em algo que pudesse servir à utilidade e proveito do público em geral, sem nenhum tipo de limitação. Em uma clara alusão à tradição clássica, seu prédio foi projetado para assemelhar-se a um templo grego. No caso russo, a concepção de seu museu nacional, o Ermitage, apresentou algumas peculiaridades. Nele as visitas eram permitidas apenas trajando-se fraque e cartola, e até a Revolução de 1917 teria sido praxe visitar as coleções sempre de cabeça descoberta, em sinal de respeito e subserviência ao próprio czar. Para maiores informações ver: SCHLOSSER, Julius Von. Las cámaras artísticas y maravillosas del renascimento tardío. Una contribuición a la historia del coleccionismo. Madri, Akal, 1988.
} 
de uma unidade nacional, consolidando-se como os verdadeiros e legítimos detentores de uma dada memória.

De acordo com Néstor Canclini essas instituições passaram a contar com repertórios fixos, como o nacionalismo, dotados de verdadeiros palcos-depósito e palcos-vitrine capazes de acumulá-los e exibi-los. Para exemplificar esta questão, Canclini utilizou-se do Museu Nacional de Antropologia (México), mostrando seu poder de centralização político- ideológico ao reunir peças de todas as regiões do país na capital (centralização do plural). Com isso o elemento nacional passou a ser representado como espetáculo, e não por meio de uma visão realista de suas relações sociais $^{406}$. A intenção dos museus nacionais seria oferecer aos visitantes estrangeiros, e especialmente aos nativos (maior parte do público), um panorama da história como base de unidade e consciência política, convertendo o povo em público, e construindo uma uniformidade aparente, responsável por esconder contradições sociais e alimentar mitos escolhidos com a finalidade de legitimar projetos políticos específicos.

A escolha das peças mediante um suposto valor estético escamotearia o assombro pelo diferente, alimentando uma falsa idéia de testemunho fiel da realidade. Na prática, estes seriam espaços de preservação do conservadorismo, sendo que os bens populares, incorporados sob o rótulo do folclore, entrariam em confronto com o olhar culto. Ulpiano Bezerra de Menezes afirmou:

"É comum lembrar o que John Q. Adams, segundo presidente da jovem república americana, no final do século XVIII: 'na democracia não há monumentos'. A frase expressa o propósito de um igualitarismo radical, mas, ao mesmo tempo, reconhece a potência do monumento como recurso classificatório, produtor de diferenciações. Paradoxalmente, entretanto, o objetivo com que se costuma justificar o monumento é unificar" ${ }^{\text {, } 07}$.

\footnotetext{
${ }^{406}$ CANCLINI, N. G. Culturas híbridas. Op. Cit.

${ }^{407}$ MENESES, U. T. B. de. "Cultura política”. Op. Cit., p. 454.
} 
Durante o séc. XIX a escolha/ valorização do patrimônio histórico tornou-se empreendimento considerável por representar parte significativa da renda de muitas cidades. Adquirindo as funções de propiciar saber e prazer a todos, tornava-se um produto cultural vendável, permitindo dar vazão às demandas por distração (sociedade do lazer), além de fornecer status e distinção àqueles que detinham e consumiam esses bens patrimoniais. Com isso o Estado, bem como parcela da iniciativa privada, incumbiu-se de capitanear ações de reconstrução e restauro visando atender às demandas do público visitante. A cidade canadense de Quebec pode ser tomada como um exemplo disso. Em seu centro histórico existe a presença de um conjunto arquitetônico francês que remete ao séc. XVIII, contudo todo o “cenário" foi construído aleatoriamente, sem base histórica alguma.

Constituídos por coleções de peças exóticas, reunidas em um processo diretamente vinculado a uma política de dominação, "os objetos são deslocados de seus usos e sentidos originais, mostrados a partir de um saber (de uma ciência) que pretende restaurar ou até mesmo instaurar outros significados". Na prática, esses ambientes, seriam destinados a "reverenciar uma determinada memória, uma determinada história" ${ }^{408}$.

Associando esse debate ao caso paulista, Silvia Lara exemplificou-o a partir da constituição do Museu Casa do Bandeirante. Incorporado ao patrimônio municipal de São Paulo em 1938, explicitaria a continuidade de importância em relação a um tema que desde o final do séc. XIX servia como amálgama à sociedade paulista $^{409}$. Se no segundo quartel do séc. XX a preocupação política em relação ao elemento alienígena (imigrante) era menor, o mesmo não pode ser dito quanto ao migrante nordestino. Assim, temas ligados ao pioneirismo paulista em tempos coloniais continuaram a ser utilizados como mecanismos de dominação e construção identitária, alimentando a imagem de São Paulo como a locomotiva do país, mesmo

\footnotetext{
408 LARA, Silvia Hunold. "História, memória e museu". In: DEPARTAMENTO DO PATRIMÔNIO HISTÓRICO. Revista do Arquivo Municipal. São Paulo, DPH, vol. 200, 1991, p. 101.

${ }^{409}$ Para maiores informações, ver Capítulo I e Capítulo II.
} 
que em um cenário diferente do prioritariamente agrário ${ }^{410}$. Na opinião de Lara, tratava-se de algo com

"sentido explícito de reunir e mostrar à população da cidade o poder e a glória desta 'raça de conquistadores'. A partir de uma concepção nitidamente celebrativa e laudatória que pretendia recriar (sem o menor rigor histórico, aliás) uma moradia colonial paulista, a Comissão [do IV Centenário] recolheu móveis, utensílios e outros objetos no interior de São Paulo, Minas Gerais e Vale do Paraíba, passando a 'mobiliar' a casa com esse acervo" ${ }^{\text {"411. }}$.

Apesar da aparente arbitrariedade, o tema do bandeirismo, inaugurado no final do séc. XIX, continuava sendo caro à historiografia paulista, presente em seu imaginário político e cultural por décadas. Um exemplo disso foi

“a criação, nos anos 70, do 'Museu Casa do Sertanista', também dedicado a divulgar 'tudo o que se relacionar com a penetração e a conquista do sertão brasileiro nos séculos XVII, XVIII e XIX', e 'também a cultura indígena, exibindo material etnográfico referente a tribus (sic) brasileiras" ${ }^{\prime 412}$.

Com tudo isso, Choay defende a tese de que o "reduto patrimonial poderá se tornar o terreno inestimável de uma lembrança de nós mesmos no futuro" ${ }^{\text {"413, }}$ deixando de ser um mero posicionamento burocrático para se transformar em uma opção social. Para tanto, a idéia de Raymond Williams poderia ser seguida mais proximamente, estabelecendo-se políticas culturais baseadas menos na oposição tradicional X moderno e mais nas diferenças existentes entre o arcaico, o residual e o emergente, permitindo desafiar o exclusivismo dos testemunhos escritos. Assim, talvez fosse possível estabelecer uma nova orientação no tocante à preservação da memória e a construção da história. Nas palavras de Maria Célia Paoli,

\footnotetext{
${ }^{410}$ Uma análise significativa dessa questão foi elaborada por Odair da Cruz Paiva em seu livro Caminhos cruzados: migração e construção do Brasil moderno (1930- 1950), mostrando, entre outras coisas, como São Paulo foi sendo construída no imaginário brasileiro como sendo a terra das oportunidades, não apenas para imigrantes mas também para todos aqueles que pretendiam uma vida melhor, longe das mazelas da seca no sertão nordestino. Bauru, EDUSC, 2004.

${ }^{411}$ LARA, S. H. "História, memória e museu". Op. Cit., pp. 103- 4.

${ }^{412}$ Idem, p. 104.

${ }^{413}$ CHOAY, F. A alegoria do patrimônio. Op. Cit., p. 257.
} 
"É exatamente aí que se encontra um dos maiores desafios: fazer com que experiências silenciadas, suprimidas ou privatizadas da população se reencontrem coma dimensão histórica. Por esta via, pode-se constituir uma política de preservação (e uma historiografia) que deverá ter em mente o quanto o poder desorganizou a posse de um sentido das participações coletivas, destruindo a possibilidade de um espaço público diferenciado.

Trazê-las à luz deve também implicar não sacralizar sua presença: uma história 'dos vencidos' não pode ser a construção de novas mitologias, mas a produção de um direito ao passado que se faz como crítica e subversão constantes das versões instituídas" ${ }^{, 14}$.

\section{2- Os arquivos como espaços patrimoniais fossilizados}

Os arquivos modernos apresentam como uma de suas características fundamentais permitir aos cidadãos e pesquisadores um acesso seguro e preciso a um conjunto informativo cada vez mais amplo. Nas palavras de Jaime Antunes da Silva, Diretor do Arquivo Nacional brasileiro, tratar-se-ia de possibilitar uma verdadeira "auditoria cidadã" aos processos administrativos estatais ${ }^{415}$, além de permitir o estabelecimento de certos vínculos entre a idéia de patrimônio e a implantação de políticas de preservação documental, capazes de refletir realidades sociais mais amplas e complexas.

Como apontado anteriormente, durante muito tempo o documento apropriado para o fazer histórico era aquele registrado por escrito. Contudo, esse conceito foi paulatinamente ampliado, agregando novas possibilidades de fontes, inclusive aquelas ligadas à cultura material. Como visto na Introdução deste trabalho, a palavra documentum derivaria de docure (ensinar), evoluindo para um caráter probatório, amplamente usado no vocabulário legislativo. Sob a ótica da escola metódica francesa, o documento parecia apresentar-se "por si como prova histórica»"416, estabelecendo uma aparente distinção entre a objetividade do

\footnotetext{
${ }^{414}$ PAOLI, M. C. "História, memória e cidadania”. Op. Cit., p. 27.

415 Expressão foi utilizada pelo Diretor do Arquivo Nacional durante o II Seminário Internacional de Arquivos de Tradição Ibérica, realizado no Rio de Janeiro, entre os dias 18 e 22 de novembro de 2002.

${ }^{416}$ LE GOFF, J. História e memória. Op. Cit., p. 526.
} 
pesquisador e a intencionalidade na composição do documento, isolado ou em conjunto.

As instituições arquivísticas foram sendo criadas para a guarda da documentação produzida/acumulada pelo poder constituído, com o intuito de acomodar grandes massas documentais capazes de subsidiar a própria administração, fornecendo material original, autêntico e fidedigno. Com isso, acabaram tornando-se espaços de guarda de uma memória específica, muitas vezes oficializada, como se ela também não se constituísse mediante o embate de diferentes agentes sociais escamoteados.

Prédios foram adaptados, ou mesmo edificados, para cumprirem a função específica de servirem de espaços de guarda a todo esse material, refletindo diretamente o empenho das estruturas governamentais em manterem grandes massas de documentos preservadas e disponíveis a eventuais consultas por parte do poder. Esses espaços tornaram-se gradativamente, verdadeiros "templos" de conservação de memória e de passado, atuando diretamente na consolidação de um espírito responsável por estabelecer coesão política e social ${ }^{417}$. Exemplos disso podem ser encontrados em todo o mundo ocidental, tanto no velho como no novo continente, sempre associados ao estabelecimento de uma identidade nacional.

Para facilitar o trabalho dos pesquisadores que a esses acervos recorriam, na virada do séc. XVIII- XIX conjuntos documentais passaram a ser sistematicamente publicados sob formas monumentalizadas, fossem eles fruto de uma acumulação natural ou como coleções temáticas de documentos originalmente isolados e esparsos. Nesse sentido, muitos desses conjuntos passaram a ser dotados de significados específicos, mesmo que não os possuindo originalmente. Isso ocorria na medida em que tais elementos recebiam uma determinada orientação quando de sua organização e eventual publicação. Alguns dos melhores exemplos são o Monumenta germaniae histórica para a Idade Média (1826) e o Monumenta historiae patriae, "refletindo" a nacionalidade italiana (1836). Quanto à formação de

\footnotetext{
${ }^{417}$ Para maiores informações, ver Capítulo II.
} 
coleções dotadas de caráter monumental, podem ser citados a Colletion de documents inédits sur l'historie de France (1835) ou os Documenti di storia italiana (1867), reunindo peças documentais de origens diversas a partir de uma suposta coesão temática. No caso paulista, os Documentos interessantes publicados pela Repartição de Arquivo apresentariam o mesmo significado, porém com uma peculiaridade. Devido a sua composição, esta série acabou por aglutinar em seus volumes características semelhantes a estes dois princípios geradores. Enquanto uma parcela dos exemplares da coleção dedicava-se à publicação de conjuntos orgânicos de documentos, como o caso das correspondências de Capitães Generais, outra parte foi utilizada para publicar documentos selecionados mediante pesquisas realizadas, fossem no próprio acervo do Arquivo, fossem em outras instituições congêneres. Esses talvez tenham sido os casos dos volumes dedicados à bernarda de Francisco Ignácio ou ao estabelecimento das divisas político-administrativas entre os estados de São Paulo e Minas Gerais.

Se Keith Jenkins tivesse razão, o passado tornou-se o próprio objeto da história, e a leitura desse passado ocorreria por intermédio da produção historiográfica, sendo impossível atingi-lo de maneira isenta, especialmente porque o historiador distancia-se dele em termos temporais e espaciais, tomando contato com esse passado apenas por meio de diferentes e diversas leituras. Com isso, um mesmo objeto poderia ser fruto de diversas interpretações, tornando infinitas as possibilidades de interpretação de mundo. Isso ocorreria devido à impossibilidade de recuperação dos acontecimentos em sua totalidade. Na prática, a verdade seria sempre criada e nunca descoberta, uma vez que sistemas de poder atuariam em seu controle. Assim, as diferentes interpretações possíveis de um mesmo evento não ganhariam perenidade por serem verdadeiras ou constituídas a partir de estruturas metodologicamente corretas, mas sim porque se apresentariam alinhadas com discursos dominantes, alimentando forte relação entre poder e saber ${ }^{418}$.

\footnotetext{
${ }^{418}$ JENKINS, K. A história repensada. Op. Cit.
} 
Nesse contexto, a força probatória e a importância do documento tornaram-se tamanhas que alguns historiadores chegaram mesmo a afirmar que se um fato não deixasse registro escrito ou mesmo gravado de alguma forma, ele teria sido perdido irremediavelmente. Para Fustel de Coulanges,

"Leis, cartas, fórmulas, crônicas e histórias, é preciso ter lido todas essas categorias de documentos sem omitir uma única [...]. Encontraremos no curso desses estudos várias opiniões modernas que não se apóiam em documentos, devemos estar em condição de afirmar que não são conformes a nenhum texto, e por essa razão não nos cremos com o direito de aderir a elas. A leitura dos documentos não serviria, pois, para nada se fosse feita com idéias preconcebidas [...]. A sua única habilidade (do historiador) consiste em tirar dos documentos tudo o que eles contêm e em não lhes acrescentar nada do que eles não contêm. $\mathrm{O}$ melhor historiador é aquele que se mantém o mais próximo possível dos textos" ${ }^{, 419}$.

Durante o séc. XX a idéia de documento preservou o seu status, mas passou por profundas transformações e ampliações em sua definição, permitindo o uso não mais de peças isoladas, mas sim organizadas em séries, preservando-se sua orientação produtiva original na medida em que refletiriam uma produção em massa.

Essa nova orientação acabou por estabelecer e alimentar o princípio da organicidade, definidor das características inerentes dos arquivos, e responsável por diferenciar tais instituições de outras congêneres, como os museus e bibliotecas. Levando-se em conta este conceito, o documento não deveria ser tratado como peça isolada de seu meio genético, tendo apenas um determinado valor intrínseco. A indivisibilidade dos conjuntos visaria sua não dispersão (princípio da proveniência ou respects des fonds ${ }^{420}$ ), alimentando a tese de que o material preservado em seu meio original teria a oferecer um volume informativo significativamente mais amplo

\footnotetext{
${ }^{419}$ Cf. LE GOFF, J. História e memória. Op. Cit., p. 527.

${ }^{420}$ Apesar de criado na França por Nataly de Wally (1841), chefe da Seção Administrativa dos Arquivos Departamentais, sua definição não fora vista como elemento conceitual. Tal categorização somente foi "lapidada" na Alemanha (1881) sob a forma de regulamento orientado para a prática arquivística. Sobre o tema, valem as leituras de: HERRERA, Antonio Heredia. El principio de procedência y los otros princípios de la archivística. São Paulo, Arq-SP, 2003; RODRIGUES, Ana Márcia Lutterbach. Uma análise da teoria dos arquivos. Dissertação de Mestrado apresentada na Escola de Ciência da Informação da Universidade Federal de Minas Gerais, 2004.
} 
que o mero somatório das partes componente dos conjuntos, possibilitando acesso à informação de maneira contextualizada ${ }^{421}$. Com isso, estabeleceu-se forte vínculo entre os arquivos e o direito, sendo o primeiro considerado o "armazém" da legislação e verdadeiro celeiro informativo para o Estado $^{422}$.

Na opinião de José Sebastião Witter tal princípio redefiniria as próprias características dessas instituições, deixando de lado a idéia de meros depósitos de coleções classificadas de maneira temática (arbitrárias e subjetivas). Adotando a idéia de respeito aos fundos, e considerando os arquivos como produtos naturais da atividade administrativa da instituição que o criou, os acervos destas instituições passariam a atender a um volume significativamente mais amplo de pesquisas, deixando de ser encaradas apenas como redutos de historiadores e eruditos ${ }^{423}$. A partir desse novo princípio adotado na acumulação e disponibilização de documentos, tais acervos adquiriam importante caráter probatório da ação políticoadministrativa, tanto de instituições públicas como privadas, bem como possibilitando o acúmulo de uma massa documental significativa, vinculada a pessoas físicas cuja relevância passaria a ser ditada por interesses sociais mais amplos.

A aparente semelhança entre acervos arquivísticos e museológicos, especialmente na perspectiva de um observador menos atento, resume-se ao apego quase "fetichista" às peças documentais, especialmente quando legitimadas pelo tempo, ou seja, mais antigas. Porém cabe aqui uma ressalva. Quando se discute acervos museais necessariamente deve-se levar em conta seu caráter artificial de coleção, ou seja, a reunião de objetos que não mantém nenhuma relação orgânica entre si, apresentando características comuns apenas aos olhos de quem os

\footnotetext{
${ }^{421}$ Para maiores informações ver: BELLOTTO, Heloísa Liberalli. "A profissão e o ensino da arquivologia". In: Boletim do Arquivo. São Paulo, Arquivo do Estado de São Paulo, v. 01, n 1, dez 1992.

${ }^{422}$ Após a Revolução Francesa, esse arsenal passou também a servir aos cidadãos. A intenção era que, com isso eles pudessem reivindicar e garantir direitos. BELLOTTO, Heloísa Liberalli. Arquivística: objetos, princípios e rumos. São Paulo, Arq-SP, 2002.

${ }^{423}$ Vale salientar que esse conceito fora elaborado pelo historiador francês Natalis de Wally em 1841, mas aceito e posto em vigor apenas algum tempo depois. Para maiores informações ver: WITTER, José Sebastião. Arquivo e história. O Arquivo do Estado de São Paulo na administração e na história. Tese de Livre Docência apresentada na FFLCH da Universidade de São Paulo, 1981, p. 30.
} 
selecionou e juntou, seja seguindo critérios estéticos, temáticos ou cronológicos ${ }^{424}$. Trata-se de material na maior parte das vezes descontextualizado, perdendo de maneira irreparável parcela significativa das informações que eles poderiam conter na origem, enquanto ainda contextualizados. $\mathrm{Na}$ opinião de Ulpiano Bezerra de Meneses, no ato criador de uma coleção ficaria patente o caráter de interlocução e interferência (subjetividade em diálogo), não sendo força de expressão permitir entendê-la como fruto de ato autobiográfico ${ }^{425}$.

Já os acervos arquivísticos, ao contrário, apresentariam uma diferença significativa em relação às coleções, estando eles intimamente ligados a dois princípios técnicos fundamentais, quais sejam, o princípio da organicidade e o da proveniência. É inegável que a questão da constituição de representações está posta em ambos os casos, tanto nos museus como arquivos. Contudo, nos arquivos, a organicidade impõe uma característica a esse material segundo a qual ele refletiria a estrutura, funções e atividades da entidade ou pessoa encarregada por acumulá-lo, no exercício natural de suas atribuições, sendo vedada qualquer possibilidade de seleção artificial de documentos.

O outro elemento distintivo, conforme visto anteriormente, diz respeito à proveniência, estabelecendo que devam ser mantidos reunidos, num mesmo fundo, todos os documentos oriundos de uma mesma fonte geradora de arquivo ${ }^{426}$. De acordo com Heloísa Bellotto tal atitude visaria manter a individualidade desses conjuntos documentais, impossibilitando tecnicamente que fossem misturados a documentos de conjuntos distintos. A não observância desse princípio poderia acarretar na construção de interpretações absolutamente equivocadas quanto à origem do material pesquisado ${ }^{427}$.

\footnotetext{
${ }^{424}$ CAMARGO, A. M. de A., BELlOTTO, H. L. (coord.). Op. Cit.

${ }^{425}$ MENESES, Ulpiano T. Bezerra de. "Memória e cultura material: documentos pessoais no espaço público". In: Estudos históricos. Rio de Janeiro, vol. 11, n 21, 1998.

${ }^{426}$ PAES, Marilena Leite. Arquivo: teoria e prática. Rio de Janeiro, FGV, 2002.

${ }^{427}$ A figura do "erudito", tipificada por Langlois e Seignobos, mostra-se atual. Caberia apenas ao pesquisador a efetivação de análises que caminhassem no sentido da intertextualidade, inclusive recorrendo a conjuntos arquivísticos distintos.
} 
O que poderia ser apenas uma diferença vulgar e superficial, apresenta-se na prática como a garantia a todo e qualquer pesquisador, independentemente do seu tema de interesse, poder analisar documentos, e as informações neles contidas, sempre em seu conjunto original, evitando-se a perda de parcela de seu valor quando analisado apenas sob o viés de seu conteúdo informativo estrito, sem levar em conta seu meio genético.

Com todos esses elementos "interferindo" no processo reconstrutivo do passado, seria um erro encarar a história como sinônimo de memória, ou mesmo o documento como seu receptáculo fiel e neutro, apesar de algumas correntes estabelecerem os arquivos como verdadeiros depósitos à disposição do historiador. Na visão de Michel Foucault, uma possibilidade seria a de a história ser vista como construção efetuada no presente a partir de vivências/ experiências ocorridas no passado, elaboradas mediante o uso de uma determinada massa documental encarregada de registrá-la. Assim, conforme discutido anteriormente, a memória constituiria o suporte fundamental da identidade individual e coletiva de um grupo, sendo por meio dela que se organiza e traduz para o outro aquilo que se reconhece como importante.

Esse "domínio" sobre a memória permitiu o estabelecimento da idéia do tempo reversível, sendo possível ao indivíduo lembrar-se daquilo que não viu porque lhe foi contado. Na opinião de Alfredo Bosi,

"O tempo reversível é, portanto, uma construção da percepção e da memória: supõe o tempo como seqüência, mas o suprime enquanto o sujeito vive a simultaneidade. $\mathrm{O}$ mito e a música, que trabalham a fundo a reversibilidade, são 'máquinas de abolir o tempo', na feliz expressão de LéviStrauss. Ora a condição de possibilidade do mito e da música é a memória, aquela memória que se dilata e se recompõe, e a qual Vico chama de fantasia. A memória vive do tempo que passou e dialeticamente, o supera" ${ }^{428}$.

\footnotetext{
${ }^{428}$ BOSI, Alfredo. "O tempo e os tempos". In: NOVAES, Adauto (org.). Tempo e história. São Paulo, Companhia das Letras/ Secretaria Municipal de Cultura, 1992, p. 27.
} 
Ao analisar a idéia de diferentes temporalidades presentes na obra do filósofo francês Henri Lefebvre, José de Souza Martins mostrou como esse autor foi capaz de perceber, por meio de seu método de análise regressivo-progressivo, a coexistência de diferentes "épocas" no desenvolvimento humano, decorrentes de momentos historicamente específicos, mas que acabavam sendo preservados em uma determinada sociedade, dando a falsa aparência de contemporaneidade. Assim, seria possível perceber que "contradições sociais são históricas e não se reduzem a confrontos de interesses entre diferentes categorias sociais" $"$ " Com isso, mesmo quando determinadas questões encontrem-se aparentemente ausentes do debate analítico, sua presença pode ser sentida na origem mais remota de sua elaboração, em um processo constitutivo que não foi capaz de romper simplesmente com seu passado, ou mesmo escamoteá-lo. Essas temporalidades singulares estão presentes simultaneamente no cotidiano social e institucional, portanto, recuperáveis para o entendimento do vivido. Em relação às instituições arquivísticas, tal elemento explicita-se nos lugares e sentidos das coletas, guarda e divulgação das bases documentais produzidas e abrigadas nesses locais.

Em termos sociais, esse tempo múltiplo seria o responsável por informar e determinar a própria ação do sujeito. Elementos contemporâneos ao crescimento econômico paulista, como as péssimas condições de moradia de parcela significativa da população, além da precariedade e fragilidade da vida, foram sistematicamente omitidos. Quando, por meio de trabalhos analítico-descritivos comumente divulgados na Revista do IHGSP e amparados nas seleções documentais publicadas nas páginas dos Documentos interessantes, tais elementos apareciam, eram para expressar a amplitude do processo de martirização a que estavam expostos os ancestrais da "pátria paulista". Na prática, serviriam tanto para alimentar a critica em relação ao elemento português, como para retratar o processo de superação bandeirante.

\footnotetext{
${ }^{429}$ MARTINS, José de Souza (org). Henri Lefebvre e o retorno à dialética. São Paulo, Hucitec, 1996, p. 22.
} 
Na visão de Odair Paiva essa variedade de tempos poderia ser exemplificada quando tomadas como exemplo as obras literárias de Mario de Andrade (Paulicéia desvairada) e Raquel de Queiroz ( $O$ quinze). A primeira retrata a "São Paulo dos bondes, dos edifícios, do burburinho urbano, da possibilidade do novo, da ruptura" ${ }^{430}$, em suma, frenética e palco de bruscas mudanças. Em $O$ quinze, Raquel de Queiroz dedicou-se a retratar a precariedade e miséria do sertanejo em decorrência da grande seca de 1915. "A vida transcorre numa situação-limite, na qual a precariedade material está acompanhada das agruras da perda da dignidade humana" ${ }^{331}$.

Apesar de contemporâneas, essas histórias foram ambientadas em situações absolutamente diferentes, não apenas pela questão espacial. Em ambos os casos os tempos vividos eram distintos. Nas palavras de Paiva,

"a modernização econômica de São Paulo na primeira metade do século XX, cujo carro-chefe, num primeiro momento, foi a cafeicultura e, posteriormente, a industrialização, sustentava-se na permanência de relações arcaicas em outra região do país, o Nordeste"

A situação torna-se ainda mais complexa quando levada em conta o posicionamento da elite paulista diante do enfrentamento com o migrante. Ideologicamente, no decorrer do séc. XX a pujança de São Paulo foi construída tanto por seu pioneirismo ancestral como, em tempos mais recentes, pela vinda do europeu. Os conflitos existentes em relação aos migrantes seriam decorrência da tentativa de "domesticação" desse novo elemento, como havia sido feito com as levas de imigrantes chegadas na segunda metade do séc. XIX, gerando conflito entre temporalidades diferentes. Para Paiva, os estranhamentos e dilemas próprios daquele

\footnotetext{
${ }^{430}$ PAIVA, Odair da Cruz. "Diferentes tempos de uma mesma história". In: CAMARGO, Ana Maria de Almeida. São Paulo: uma viagem no tempo. São Paulo, CIEE, 2005, p. 106.

${ }^{431}$ Ibidem.

${ }^{432}$ Idem, p. 109.
} 
tempo histórico foram explicitados pela identificação de fronteiras oriundas de "outro tempo" "433.

Sob esta perspectiva, seria possível afirmar que o esquecimento em relação a determinadas facetas do passado seria o mesmo que negar as experiências adquiridas no vivido, eliminando-se do futuro a possibilidade transformadora do novo. Ao analisar a obra de Heidegger, Benedito Nunes apontou os vínculos profundos existentes entre o fazer história e o tempo, especialmente aquele do historiador. $\mathrm{O}$ exercício de voltar-se ao passado acabaria possibilitando sua recomposição fosse como uma história monumental, "que elege as realizações dignas de serem imitadas", ou por uma história antiquaria, "que venera o que existiu como patrimônio a ser conservado" (culto ao antigo, pelo simples fato de sê-lo). Uma terceira possibilidade seria o estabelecimento de uma história crítica, "que julga os outros tempos em nome das necessidades ou urgências do presente" ${ }^{434}$.

Com exceção dessa última modalidade do fazer história, as demais estariam fortemente vinculadas a uma idéia de que "o antes é a semente, o germe, a raiz do depois ${ }^{\text {"435 }}$, estabelecendo-se forte vínculo com a idéia de progresso. $\mathrm{Na}$ opinião de Alfredo Bosi este conceito atravessaria grave crise especialmente devido ao avanço tecnológico que, além de destruir a natureza, não foi capaz de sanar a miséria do mundo nem harmonizar o convívio entre os povos.

Sendo assim, as narrativas dos historiadores "não constroem um tempo monolítico, mas tempos diversos". Para Catherine Darbo-Peschanski a percepção de existência de tempos diferentes para grupos humanos distintos permitiu sua utilização quanto à hierarquização de povos distintos, vivendo em estágios de desenvolvimento tecnológicos diferentes, ou mesmo "inferiores", o que possibilitaria a implantação de idéias civilizadoras. Com isso seria comum a criação

\footnotetext{
${ }^{433}$ Idem, p. 110. Vale salientar que elementos semelhantes de estranhamento, controle e convivência foram estabelecidos também com o imigrante europeu, docilizado fosse por meio da lógica educacional, militar ou policial. Para maiores informações, ver Capítulo I.

${ }^{434}$ Para uma análise mais aprofundada sobre o tema, ver: NUNES, Benedito. "Experiências do tempo". In: Idem, p. 139.

${ }^{435}$ BOSI, A. "O tempo e os tempos". Op. Cit., p.21.
} 
de narrativas de origem, buscando estabelecer ancestralidade. Em muitos casos, territórios ocupados pela ação expansionista humana passaram a ser vistos como áreas descendentes, verdadeiras ramificações, tributárias de uma mesma memória ${ }^{436}$. Esta talvez tenha sido a tentativa dos Documentos interessantes ao compilarem não apenas os atos administrativos oriundos dos Capitães Generais, mas especialmente aqueles relacionados à ação portuguesa no interior da capitania, como o caso do sertão do Iguatemi, ou as expedições dirigidas à região do Tibagi. Nesses exemplos a administração portuguesa era sempre vista como omissa e irresponsável, deixando os bravos paulistas pioneiros abandonados à própria sorte, ou quando não, negociando "às escondidas" com o governo espanhol para que territórios fossem "devolvidos". Assim, o sertão pertenceria legitimamente a seus desbravadores, cabendo ao bandeirante de São Paulo o "privilégio" de usufruir das riquezas dessas regiões, caso não tivesse sido alijado mediante ação "predatória" da Coroa.

Para Le Goff, o advento da escrita permitiu à memória assumir certo caráter monumental e comemorativo de lembranças, especialmente a partir do mundo greco-romano, em que os registros feitos em pedra garantiam a publicidade e durabilidade da memória. Esses monumentos ganhariam o status de suporte da memória coletiva, trazendo consigo traços indiscutíveis e indeléveis do passado. Assim, a sobrevivência de determinados elementos não seria fruto do acaso, nem tão pouco resultado da preservação do todo, mas sim ocasionado por uma ação deliberada de escolhas, cuja intencionalidade seria a de "congelar" no tempo determinadas possibilidades reconstrutivas do passado.

$\mathrm{Na}$ opinião de Michel Foucault, durante muito tempo o historiador buscou transformar o monumento em documento para poder ouvi-lo, mesmo que de forma não verbal. Contudo, na contemporaneidade tem-se exercido um papel diametralmente oposto, apesar de complementar. Sendo assim, hoje é essa mesma história que transforma o documento em monumento. Em sua opinião,

\footnotetext{
${ }^{436}$ PESCHANSKI. Catherine Darbo. "Os tempos da história”. In: Idem.
} 
“A história, na sua forma i, dedicava-se à 'memorizar' os monumentos do passado, a transformá-los em documentos e em fazer falar os traços que, por si próprios, muitas vezes não são absolutamente verbais, ou dizem em silêncio outra coisa diferente do que dizem; nos nossos dias a história é o que transforma os documentos em monumentos e o que, onde dantes se tentava reconhecer em negativo o que eles tinham sido, apresenta agora uma massa de elementos que é preciso depois isolar, reagrupar, tornar pertinentes, colocar em relação, construir em conjunto" 437 .

Com isso, preservar determinados tipos de documentos tornou-se prioridade tanto para membros de grupos ideologicamente dominantes como para os próprios historiadores, muitas vezes a eles ligados, permitindo apenas a reconstituição de uma "história oficial".

Na opinião de alguns especialistas, o documento teria sido transformado em monumento quando da sua utilização por parte do poder. O fortalecimento dos arquivos (ainda no séc. XIII) teria tido por interesse conservar a memória escrita para que ela tivesse maior durabilidade. Com isso, e ampliado pelo crescimento urbano, proliferaram-se arquivos notariais por toda a Europa, ficando a cargo de corpos municipais que os tornaram receptáculos de uma identidade coletiva una e coesa. Todo esse conjunto de elementos acabou por alimentar um caráter patrimonialista, atribuindo a estas instituições nascentes e constantemente ameaçadas, o poder de representarem uma identidade coletiva e comunitária, conservando sua memória na forma escrita para que esta tivesse maior durabilidade. $\mathrm{Na}$ prática, os arquivos tornaram-se responsáveis por salvaguardar a "verdade" por eles divulgada, fosse por meio da adoção de inúmeros critérios de descarte, fosse por meio da produção de instrumentos de pesquisa capazes de "recuperar" certas informações custodiadas em seus acervos, ou mesmo utilizando-se de recursos editoriais, como a publicação de documentos selecionados e transcritos, dando a falsa aparência de que toda a diversidade político-administrativa estivesse ali contemplada ou mesmo registrada.

${ }^{437}$ Cf. LE GOFF. História e memória. Op. Cit., p. 536. 
Foi nesse contexto que os primeiros inventários foram produzidos, ainda no séc. XIV, objetivando garantir a preservação de determinados documentos bem como o "acesso" a esse material por parte do poder ${ }^{438}$.

Com a abertura dos arquivos vinculados a Estados nacionais e sua publicização (a partir de 1794) documentos "oficiais" tornaram-se disponíveis à memória nacional, o mesmo ocorrendo mediante o surgimento dos museus públicos. Vale salientar que nesse contexto a França revolucionária mostrou-se modelar para o restante do mundo "civilizado", com suas listas de documentos incorporados ao poder estatal mediante o confisco e tombamento de parcela dos bens da nobreza e da própria Igreja.

Para Le Goff, o documento poderia ser produzido/ acumulado como um monumento mesmo que por uma intencionalidade inconsciente, o que tornaria cada vez mais necessário o estabelecimento de mecanismos de crítica interna por parte do pesquisador. Assim, tal monumentalização ocorreria como resultado do "esforço das sociedades históricas para impor ao futuro- voluntária ou involuntariamentedeterminada imagem de si próprio" 439 . O ofício do historiador teria sempre como produto a montagem, consciente ou não, da história mediante a escolha dos documentos utilizados,

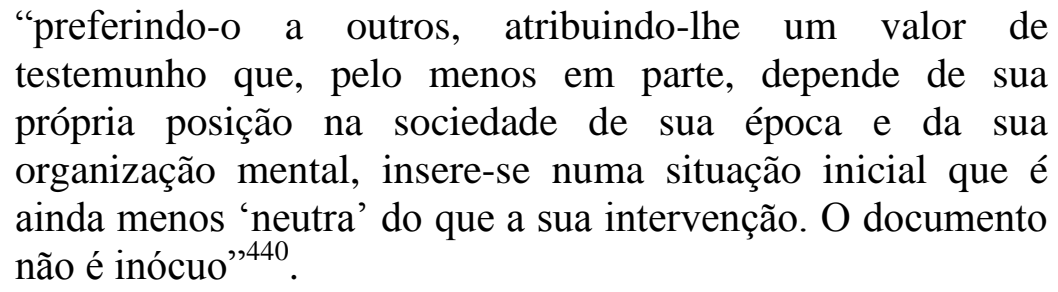
testemunho que, pelo menos em parte, depende de sua própria posição na sociedade de sua época e da sua organização mental, insere-se numa situação inicial que é ainda menos 'neutra' do que a sua intervenção. $\mathrm{O}$ documento não é inócuo",440.

Sendo assim, o estabelecimento de instituições cujo grande objetivo seria a guarda e disponibilização de documentos acabou por solidificar determinadas possibilidades historiográficas, deixando de lado inúmeras alternativas. Atos

\footnotetext{
${ }^{438}$ De acordo com Jacques Le Goff, esse pioneirismo poderia ser atribuído a iniciativas que partiram do rei Carlos V da França e do papa Urbano V. Idem.

${ }^{439}$ Idem, p. 538.

${ }^{440}$ Idem, p. 537.
} 
governamentais, consolidados em suas mais diversas instâncias, acabaram por encontrar nos arquivos públicos seu espaço de preservação sacralizado. Como exigência administrativa, a implantação de políticas destinadas ao recolhimento de documentos transformou-se em uma ferramenta eficiente para o controle exercido por e sobre os arquivos, estabelecendo regras para quais documentos deveriam, ou não, ser incorporados aos acervos das instituições. Para José Honório Rodrigues (Diretor do Arquivo Nacional entre os anos de 1958 e 1963) essa atitude seria a responsável por estabelecer aos arquivos seu caráter eminentemente administrativo e supostamente neutro. Em sua opinião, "como arsenais da administração eles não destroem a missão histórica, nem se deve pensar que haja uma competição entre a História e a Administração"441.

Se por um lado todo esse material seria dotado de certa verdade e um importante caráter probatório, não apenas quanto a determinados atos do poder público, mas também legal, ou quanto à existência de determinadas estruturas e seus funcionamentos, o simples estabelecimento de critérios sobre o que deveria, ou não, ser recolhido, já seria argumento suficiente para por em cheque um suposto aparato de neutralidade. Inegavelmente todo o documento pode ser avaliado quanto a sua fidedignidade, autenticidade e legalidade, contudo atribuir a ele um caráter de "verdadeiro" quanto ao seu potencial interpretativo é deixar de lado todas as possibilidades decorrentes do próprio fazer histórico, atributo inerente do pesquisador, responsável por suas escolhas temáticas e critérios de seleção documental. Vale lembrar que se para a escola metódica, encabeçada por Charles Langlois e Charles Seignobos, o documento falsificado perderia qualquer importância historiográfica por não ser detentor de uma verdade inconteste, textos apócrifos ou mesmo informações sustentadas por um autor incapaz de bem

\footnotetext{
${ }^{441}$ RODRIGUES, José Honório. A situação do Arquivo Nacional. Rio de Janeiro, Ministério da Justiça e Negócios Interiores, 1959, p. 10. In: ARQUIVO NACIONAL. O Arquivo Nacional: 1838- 2004. Rio de Janeiro, Arquivo Nacional, 2004.

http://www.portalan.arquivonacional.gov.br/Media/Catalogo\%20Institucional.pdf (acessado em 22 de junho de 2009).
} 
informar-se dos fatos, deveriam também ser rejeitados ${ }^{442}$. Esse posicionamento serviria para expurgar os documentos tidos como "imprestáveis, que só serviriam para confundir e levar ao erro"443, especialmente em um cenário em que a autenticidade não poderia ser confundida com sinceridade pois, significaria apenas atestar a procedência das informações e não a exatidão de seu conteúdo.

Por outro lado, em meados do séc. XX Marc Bloch defendia a importância de manterem-se preservados documentos mesmo quando falsificados. Para ele não se tratava de existir a possibilidade de obtenção de respostas "verdadeiras" mediante perguntas dirigidas ao conteúdo intrínseco dos documentos, por se tratarem de falsificações. Mas na medida em que o documento não traria consigo respostas, ou mesmo falaria por si mesmo, apenas respondendo ao que lhe fora perguntado, dentro de suas limitações, bastaria mudar o tipo de pergunta para tornar esse documento historiograficamente importante. Questionamentos feitos quanto ao teor dos documentos permitiriam, sempre, respostas inúteis por se tratar de uma fraude, mas se levado em conta os por quês de tais falsificações, assim como quem as teria feito e quais os seus motivos geradores, o pesquisador poderia obter respostas importantes ${ }^{444}$.

Na opinião de Langlois e Seignobos seria fortemente criticável a forma com que boa parte dos documentos antigos teriam sido preservados, muito tendo se perdido ou não passando de cópias que dificilmente se poderia atestar a autenticidade. Daí viria a importância da seleção e guarda de "bons textos", indispensáveis ao ofício do historiador. Na busca por uma determinada "pureza" dos documentos históricos, os pesquisadores de carreira deparar-se-iam com a necessidade de trabalhos eficientes, realizados por eruditos, capazes de oferecer aos historiadores a "certeza de que carecem"445. Em decorrência disso surgiria a necessidade não apenas de preservação dos documentos originais, mas também

\footnotetext{
${ }^{442}$ LANGLOIS, Charles; SEIGNOBOS, Charles. Introdução aos estudos históricos. São Paulo, Editora Renascença, 1946, p. 138.

${ }^{443}$ Idem, p. 70.

${ }^{444}$ BLOCH, Marc. Apologia da história ou o ofício do historiador. Rio de Janeiro, Jorge Zahar Editor, 2001.

${ }^{445}$ LANGLOIS, C.; SEIGNOBOS, C. Introdução. Op. Cit., p. 52.
} 
garantir que fossem publicados de maneira "correta", evitando-se erros comuns como supressão de linhas ou palavras trocadas.

Nesse sentido os acervos destinados à guarda permanente, especialmente em arquivos públicos, ganhariam outra dimensão. Seu caráter pragmático de atender às demandas dos historiadores não se restringiria apenas ao recolhimento e preservação dos originais, mas sim seria ampliado para a publicação de seleções desses mesmos documentos, capazes de subsidiarem futuras pesquisas. Com isso, todo esse material acabaria solidificado sob a égide da "verdade", monumentalizado sob a perspectiva de único manancial respeitável para a pesquisa, na medida em que todas as avaliações externas já teriam sido levadas a cabo.

Tanto as instituições arquivísticas quanto os documentos por ela armazenados acabaram adquirindo um forte caráter patrimonial imutável, realimentando a idéia de que estas instituições seriam verdadeiros depósitos da história, responsáveis por subsidiar uma efetiva formação cidadã de seus compatriotas, como se os documentos ali preservados não tivessem, eles mesmos, sido alvos de escolhas que refletiram embates político-administrativos.

Muitas vezes, a própria mudança de sede, como as que ocorreram com o Arquivo do Estado, legitimavam-se pelo discurso preservacionista de uma determinada memória elitista. Assim, esses espaços tornaram-se tão mimetizados à paisagem que acabaram sendo reduzidos a parte do próprio mobiliário urbano, descaracterizados de sua função primeira, por vezes até mesmo perdendo seu caráter político, e terminando como mera referência topográfica, por vezes nômade ou exilado em diferentes espaços da cidade ${ }^{446}$.

\section{3- O uso dos arquivos como espaços de representações}

\footnotetext{
${ }^{446}$ MENESES, Ulpiano T. Bezerra de. "Cultura política”. Op. Cit., p. 455- 6.
} 
Se temas como a memória e o patrimônio encontraram nesse capítulo espaço para discussão, outra questão merecedora de destaque, especialmente por sua intima ligação, diz respeito ao uso dos conjuntos arquivísticos como subsidiários de representações. Se por um lado, arquivos, especialmente os públicos, tornaram-se espaços próprios para a elaboração da imagem desejada pelo Estado sobre si, frente à opinião da sociedade civil, por outro, permitiu a essa mesma sociedade construir interpretações diversas sobre esse mesmo Estado a partir do acesso aos atos por ele realizados. Tornaram-se, de fato, subsidiários importantes na construção de representações, especialmente porque aí os diferentes tempos históricos se fazem presentes no seu conjunto e não de maneira isolada, ou mesmo fragmentada, sendo possível perceber que o fazer histórico não está apenas no ato intencional de criação do novo em detrimento do velho, mas também nos desencontros e repetições ${ }^{447}$. Se em todas as escolhas de fatos históricos a serem estudados as diversidades de tempos sociais se fazem presentes, cabendo ao pesquisador atentar-se a eles, nos arquivos o próprio princípio da organicidade garante sua preservação e visibilidade como condição sine qua non de existência.

Assim sendo, o caso dos Documentos interessantes mostra-se emblemático pois, apesar de sua publicação ter sido iniciada no final do séc. XIX, seu caráter monumental e seus critérios de seleção, associando a história de São Paulo aos atos heróicos de seus habitantes e à administração de seus Capitães-Generais, estendeuse até o final do séc. XX, mesmo em uma época em que tanto o fazer história como a arquivística consolidavam-se em um novo cenário, propondo elementos teóricos e técnicos diferenciados. Tais escolhas abriram mão da diversidade em nome de um único caminho possível, favorecendo a manutenção de poder e status a um determinado grupo social. Em uma região cuja figura do imigrante foi sendo constituída como um verdadeiro paradigma à constituição de sua imagem moderna, nada melhor do que "docilizá-la" diante da ancestralidade paulista. Mesmo nesse caso, as fendas e rupturas continuam presentes, mas escamoteadas sob o manto do

\footnotetext{
${ }^{447}$ MARTINS, José de Souza (org). Henri Lefebvre e o retorno à dialética. São Paulo, HUCITEC, 1996.
} 
tempo, responsável por legitimar tradições utilizando-se de um discurso homogenizador.

Henri Lefebvre afirmava que diante da existência de um discurso, haveria sempre a falsidade, com motivações e poderes ocultados por palavras e gestos, não cabendo a redução desses elementos apenas aos seus veículos lingüísticos nem a suportes sociais. Para ele, se a linguagem teria alguma função esta seria, em primeiro lugar, a de dissimulação. Em todo o seu processo constitutivo o discurso não seria apenas uma concatenação de signos e significações, mas sim, a aplicação de valores e normas admitidas em uma dada sociedade, atribuindo a ele um sentido $^{448}$. Assim, a construção do discurso histórico seria um espaço próprio de representações, superando-se as críticas que a colocam ora como verdade, ora mentira, na medida em que inexiste, no campo do conhecimento, uma verdade acabada. A criação de séries editoriais dedicadas à publicação de documentos originais selecionados junto a acervos públicos nada mais seria que elaboração de um discurso oficial.

É importante salientar que cada representação, em seu tempo e contexto, tornar-se-ia central e privilegiada, agindo verdadeiramente como sujeito de atenção da análise. É o que Lefebvre chama de superposição da tríade representanterepresentado- representação à díade significante- significado, ou sujeito- objeto, na medida em que o presente conviveria com seu passado, dialogando com suas possibilidades no futuro.

O campo das representações foi visto pelo autor como um espaço de possibilidades, no constante diálogo entre o que impede e o que permite, sendo ele verdadeiramente responsável pela formação dos tecidos sociais mais fundamentais. Seria esse o ambiente próprio da mediação para a construção histórica, na medida em que presenças e ausências não se excluem, mas sim, pressupõe uma a outra. $O$

\footnotetext{
${ }^{448}$ LEFEBVRE, Henri. La presencia y la ausencia. Contribución a la teoria de las representaciones. México, Fondo de Cultura Económica, 1983.
} 
desprezo e a substituição das representações seriam operações mantidas perpetuamente na constituição da história.

A compreensão de como determinadas representações seriam constituídas deveria levar em conta o modo de vida de grupos humanos e o resultado de uma determinada correlação de forças. Apenas debruçando-se verticalmente na complexidade da vida social seria possível decompor a realidade e perceber a coexistência, no presente, de elementos preservados e/ou reelaborados ao longo da trajetória de determinados grupos, possíveis de serem recuperados pela trama documental reunida em diversas instituições, especialmente aquelas mantidas pelo Estado, permitindo reconstituir a história do órgão gerador e os sujeitos envolvidos.

Criar uma representação sobre algo implicaria em um exercício de valoração. Contudo, para que algo pudesse ser valorado, precisaria antes ser representado, e essa atribuição de valor alteraria a própria representação, criando outra, em um verdadeiro processo dialético. A situação tornar-se-ia complexa a ponto de o próprio indivíduo somente se perceber na "plenitude" através do outro (alteridade), não existindo a presença em si, mas sim uma representação. "Se é certo, desde Kant, que o sujeito não se representa senão pelo objeto (e inversamente), não é igualmente certo que o infinito não se represente senão pelo finito?"449

Para Ulpiano Bezerra de Meneses todo fenômeno material traria intrínseco a ele um caráter parcial, estabelecendo distinção entre os componentes materiais e não materiais da cultura. Em sua opinião, a cultura seria definida como prática e representação social, mediante articulações constantes, sendo indissolúveis esses dois elementos. Sob esta perspectiva, seria falsa a tentativa de restituição do acontecimento em si, qualquer que fosse ele, visto que sua compreensão ocorreria apenas mediante uma observação "legitimada na convicção segundo a qual aquilo que foi possui em si sua própria identidade" ${ }^{450}$. Vale lembrar que esse elemento

\footnotetext{
${ }^{449}$ Idem, p. 63.

450 MENESES, Ulpiano T. Bezerra. "A cultura material no estudo das sociedades antigas". In: Revista de história. São Paulo, no 115, jul- dez., 1983, p. 111.
} 
oscila no tempo, cabendo diferentes explicações quando se analisa o processo por meio de mecanismo que levam em conta a longa duração. Sendo assim,

"o acontecimento é instaurado pela operação de conhecimento (como já vimos), de maneira que é uma ilusão dispor, de um lado, os fatos, de outro, a teoria. No caso da documentação arquivística, esta ilusão se desdobra e agrava na medida em que se estabelece coincidência entre fato real e relato verbal (eu diria, quase, fato verbal). No entanto, o documento escrito é essencialmente representação (e, enquanto tal, naturalmente, parte da realidade a que se refere). Não é o equivalente verbal" ${ }^{\text {"51 }}$.

Sob essa perspectiva, o passado permaneceria vivo no presente, não por sua existência concreta, mas sim, mediado por ausências estabelecidas por escolhas, muitas vezes deliberadas. O próprio presente encontraria representação no passado utilizando-se de mecanismos de recordação, fazendo com que suas representações tornem-se objetos ativos da preocupação analítica do historiador.

Um bom exemplo desse tipo de operação é o que fez o inglês E. P. Thompson. Em seu livro Senhores e caçadores o autor discutiu a ação da chamada "Lei Negra" na Inglaterra do primeiro quartel do séc. XVIII ${ }^{452}$. Tratava-se de uma legislação criada para atuar em defesa da propriedade e ordem pública, estabelecendo a morte como penalidade. Tal medida foi posta em prática especialmente contra pessoas acusadas de andarem armadas e escondidas atrás de disfarces, como escurecer a face com fuligem para não serem reconhecidos, praticando delitos como caça de cervos e derrubada de madeira em áreas florestais ${ }^{453}$. O que originalmente, para o próprio Thompson, era para ser apenas um artigo acadêmico tornou-se uma obra exemplar, e até mesmo uma aula de metodologia do fazer história como ofício. O autor buscou junto a documentos pouco convencionais (todos eles minuciosamente referenciados) explicações quanto aos motivadores da Lei; quem eram os elementos envolvidos como criminosos e o

\footnotetext{
${ }^{451}$ Ibidem.

${ }^{452}$ THOMPSON, E. P. Senhores e caçadores: a origem da lei negra. Rio de Janeiro, Paz e Terra, 1987.

${ }^{453}$ Conforme colocado por Thompson, a função legal da floresta era servir ao Rei como "uma distração das preocupações do Estado". Idem, p. 32.
} 
porquê de sua confecção, na medida em que boa parte das ações de que os "negros" foram acusados não serem cometidas contra prerrogativas reais, mas contra nobres e fidalgos.

Além de todo o trabalho de análise, um dos elementos que mais chama a atenção diz respeito à explicitação, por parte do próprio autor, das inferências que ele faz junto à documentação, assim como as possibilidades interpretativas aventadas por ele. Quando, a partir da documentação, Thompson estabelece nome e profissão dos "negros", deixa claro que se trata de uma listagem que pode apresentar erros de origem como o registro de um nome, imprecisões ou mesmo homônimos, tão comum no universo das florestas inglesas. Para Thompson não se deve considerar

"o trabalho de inferência, a partir de fontes que os qualificadores chamam de 'literária', como uma atividade historiográfica menor. Se os registros das Sessões Judiciais nos fornecessem uma série ordenada de profissões, faria bela figura numa tabela; mas a tabela parcial que eles realmente forneceram (...) revela-se enganosa. Apenas a cuidadosa contextualização pode testar o significado das cifras. E talvez uma série muito boa de números seja um estímulo à preguiça do historiador. Em todo caso a ausência de fontes prontas obrigou-me a procurar adiante evidências próximas, e esse capítulo de inferências e conjecturas custou-me mais semanas de pesquisa e mais semanas de trabalho para dispô-las em alguma ordem do que qualquer outra parte do livro" 454 .

É inegável que toda a leitura feita desse material levará inevitavelmente à elaboração de representações diferentes, mediante operações distintas do saber, manifestadas na diversidade interpretativa da historiografia. Contudo, existe a possibilidade de constantes reconstruções dessa representação, em diversos contextos ou sobre diferentes olhares, utilizando-se sempre dos mesmos conjuntos

\footnotetext{
${ }^{454}$ Idem, p. 144.
} 
documentais, especialmente quando preservados seguindo-se a lógica estabelecida pela arquivística ${ }^{455}$.

Com toda a certeza a série Documentos interessantes enquadra-se nesse caso pois, mesmo tendo sido criada visando atender a uma demanda historicamente demarcada, em uma clara associação entre um órgão público (a Repartição de Estatística) e a iniciativa privada (o IHGSP), foi responsável por fornecer subsídios a uma determinada representação acerca de São Paulo e seu passado "glorioso". A própria coleção, como reflexo do funcionamento da instituição, serviu de representação da Repartição sobre si mesma e sua função de guardiã fiel do passado e memória paulista, como se fosse possível monumentalizá-las de maneira imutável ${ }^{456}$.

Decorre daí a importância de estudos cada vez mais aprofundados que levem em conta a realidade dos conjuntos documentais arquivísticos disponíveis à consulta, especialmente aqueles editados por instituições que possuem fé pública, bem como seu processo acumulativo, explicitando a relação existente tanto dos documentos entre si como com seu órgão gerador (contexto). Além disso, mostra-se necessário explicitar-se os critérios adotados durante eventuais processos de seleção, garantindo assim uma percepção mais nítida do caráter de representação construído em torno de conjuntos documentais arquivísticos, bem como das instituições responsáveis pela guarda documental.

Apesar de teóricos como Luciana Duranti afirmarem ser o documento a corporificação do fato, o que está sendo deixado de lado é que tal materialização, mesmo como resultado natural de uma determinada ação administrativa, traria

\footnotetext{
${ }^{455}$ Para Ana Maria Camargo, a "Arquivística é marcada pela transversalidade de seu objeto: que não são os documentos de um modo geral, mas os que justificam sua existência pela força probatória, que não são as informações neles contidas, mas sua forma e o contexto que lhes dá relevância; que não é o conhecimento que se pode construir a partir de suas reservas de sentido, mas a correspondência que mantém com as ações para as quais serviram de instrumento e que lhes conferem um caráter específico e único". CAMARGO, Ana Maria de Almeida. "Por um modelo de formação arquivística". In: Ciências e letras. Porto Alegre, n 31, janjun 2002, p. 194.

${ }^{456}$ Uma tipificação mais aprofundada foi realizada no Capítulo II dessa dissertação. Vale destacar que ainda hoje, após tantas mudanças institucionais, o Arquivo do Estado ainda se vê como instituição depositária/detentora da memória paulista, como se isso não fosse fruto de construção social, conforme discutido no início desse Capítulo.
} 
consigo a intensionalidade difusa de grupos em litígio, sendo impossível negar seu caráter probatório e de atestação, mas também necessário levar em conta a intencionalidade do ato que o constituiu e o preservou. Apesar de todo o processo de valoração ser atribuído a ações específicas, oriundas do próprio pesquisador, permitindo-se inúmeras ilações e interpretações, esses conjuntos documentais não poderiam ser vistos como meios propriamente neutros pois, a própria acumulação mediada pelo princípio da organicidade, já atribuiria a ele um certo critério e valor, inclusive o probatório, numa tentativa de refletir o próprio modus faciendi da instituição geradora.

Essa questão suscita debates ainda mais acalorados quando levado em conta ações como as da Repartição de Estatística e Arquivo quando se responsabilizou por publicar aquilo que seria interessante ao público leitor, abrindo mão do que para Ana Maria Camargo seria um dos atributos cruciais dos documentos de arquivo, qual seja, seu poder de imposição "a partir do lugar, físico ou lógico, de onde pode exercer plenamente a função instrumental que lhe deu origem" ${ }^{457}$. Certamente ela tem razão quando afirma que

"O documento impõe-se, então, de uma forma complexa e plural, na medida em que não prescinde do contexto (lugar e ordem) para preservar sua identidade, ou seja, para garantir a estabilidade de seu estatuto probatório" ${ }^{458}$.

Contudo não se pode perder de vista que tais colocações seriam válidas mediante a adoção de procedimentos técnicos elaborados no decorrer da segunda metade do séc. XX. No caso de muitas instituições arquivísticas, assim como seus trabalhos de intervenção técnica, os procedimentos levados a cabo foram legitimados por critérios anteriormente estabelecidos, sendo viável a seleção e confecção de grandes coleções documentais, cujo objetivo seria atender apenas a

\footnotetext{
457 Vale lembrar que na publicação dos Documentos interessantes não se registrou a localização física dos originais, nem tampouco a qual conjunto eles pertenciam. Para maiores informações ver Anexos I e III. CAMARGO, A. M. de A. "Por um modelo de formação arquivística". Op. Cit., p. 192.

458 Ibidem.
} 
determinados interesses de pesquisa, especialmente histórica, não levando em conta, propriamente, o princípio da não-intervenção.

Nas palavras de Michel de Certeau "a transformação da arquivística é o ponto de partida e a condição de uma nova história". Em A escrita de história, o autor ressalta os laços que unem a escrita sobre o passado a um conjunto de procedimentos científicos próprios de um momento e um lugar social. Sendo assim, aquilo que o historiador produz não pode prescindir da particularidade do lugar de onde se fala, ficando as representações sobre o passado definidas por procedimentos específicos, de acordo com o lugar social em que foi produzido determinado discurso $^{459}$. Uma representação construída sobre o passado pode ser usada como ferramenta da luta política, especialmente devido ao seu grande poder de legitimação de estruturas e privilégios, permitindo que diferentes grupos busquem sua identificação.

Com isso, a produção de um discurso historiográfico a partir de uma determinada instituição "possuidora" de saber (como é o caso do Arquivo do Estado) não significaria anular o seu caráter político e ideológico, visto que ela ocuparia um lugar definido na sociedade e diante das lutas nas quais o historiador, e a própria instituição, estão inseridos organicamente, estabelecendo-se uma tensão constante entre os valores e normas da disciplina história e as demandas sociais às quais se coloca o historiador.

As instituições arquivísticas seriam as responsáveis por acumular em seus acervos as diferentes facetas registradas no vivido, decorrentes dos inúmeros tempos históricos que agregam. Esse elemento permitiria explicitar os lugares e os sentidos de um determinado recolhimento documental, bem como os motivadores da guarda e divulgação do material abrigado nesses locais, proporcionando ao usuário "de outro tempo e lugar, dispor de representação aproximada da entidade que deseja conhecer, $^{\prime 460}$.

\footnotetext{
${ }^{459}$ CERTEAU, Michel. A escrita da história. Rio de Janeiro, Forense Universitária, 2006.

${ }^{460}$ CAMARGO, A. M. de A. "Por um modelo de formação arquivística". Op. Cit., p. 193.
} 
Sob essa nova perspectiva, os mesmos arquivos que auxiliaram na construção do culto ao herói e ao indivíduo, passariam a fornecer subsídios para uma nova historiografia, preocupada com o coletivo e outros agentes sociais, negando essas antigas representações em nome de outras. Sendo isso, a mera apresentação de dados extraídos dos documentos, como ilustrações, passariam a ser vistos como amorfos, cabendo ao historiador (re)construir o fato histórico, na medida em que o documento "não mais fala por si só, cabendo a uma atividade teórica a sua construção"461.

Se por um lado a questão das múltiplas potencialidades de análise existentes em um determinado conjunto documental mostra-se cada vez mais clara, por outro, na longa tradição historiográfica brasileira, tributária de tendências européias, os arquivos tornaram-se espaços privilegiados (quase restritos) de um público especializado. Durante muito tempo, imaginou-se ser ali um local exclusivo para a forja da história, quase seu berço, utilizando-se de documentos que valeriam por si mesmo, independentemente de seu contexto, confundindo-se história com colecionismo ${ }^{462}$. Assim,

“(...) administradores não sentiram escrúpulos, em nenhum país, em dividir e dispersar os documentos de uma mesma origem, nem em agrupar e misturar os documentos quando a necessidade se fazia sentir.

A classificação dos documentos nos arquivos reflete a concepção que se tem da história, com o predomínio das divisões por matérias, temas, lugares e com o rompimento da ordem na qual os documentos foram produzidos" $"$.

O estabelecimento desse novo diálogo com as fontes possibilitou à historiografia não apenas manter-se viva ao longo do tempo, mas também consolidar-se como ramo de interesse acadêmico. As diferentes visões metodológicas sobre o fazer pesquisa, assim como as questões e dilemas mais

\footnotetext{
${ }^{461}$ WITTER, J. S.. Arquivo e história.. Op. Cit., p. 26.

${ }^{462}$ Apesar das críticas, vale lembrar que essa tendência persiste até os dias de hoje, em uma marca inquestionável do conservadorismo acadêmico e da manutenção de antigas estruturas de construção de saber (resistências).

${ }^{463}$ Idem, p. 22.
} 
relevantes para o historiador em determinados momentos, poderiam ser aí percebidos.

Um bom exemplo disso diz respeito ao conflito historiográfico que durante algum tempo persistiu no Brasil quanto à possibilidade, ou não, de se fazer pesquisas acadêmicas tendo como tema a escravidão africana no país. Para muitos, a ação deletéria de Rui Barbosa ordenando a destruição da documentação fazendária a esse respeito implicava na impossibilidade de execução de qualquer trabalho sério sobre esse tema devido à precariedade das fontes. Na prática, a ação governamental conseguiu recolher e destruir livros de matrículas e demais documentos sobre escravos que estivessem em poder das repartições do Ministério da Fazenda. Isso ocorreu depois de árdua batalha política, que se arrastava desde o Império, cujo objetivo, especialmente da elite escravista nacional, era a obtenção de indenização por parte dos cofres públicos devido ao fim da escravidão. Apenas para se ter uma idéia, entre os meses de julho e novembro de 1888 foram feitas 79 representações junto à Câmara Federal e Senado solicitando ressarcimento aos fazendeiros “prejudicados”. Em um projeto apresentado pelo Barão de Cotegipe $^{464}$, em 1888, podia-se ler que tal atitude seria necessária para solucionar os "prejuízos que [os fazendeiros] sofreram com a rápida e inesperada abolição da escravidão no Brasil”. De acordo com Américo Jacobina Lacombe, a ação de Rui Barbosa tinha como objetivo matar no nascedouro a idéia de indenização, queimando todos os comprovantes fiscais existente no seu Ministério. Tal medida foi amplamente defendida por parcela da população brasileira quando da sua execução, especialmente por aqueles ligados ao movimento abolicionista, como foi o caso de Joaquim Nabuco $^{465}$. Ainda como Ministro, em despacho de 11 de novembro de 1890, Rui Barbosa respondia a um pedido de indenização promovido por um senhor

\footnotetext{
${ }^{464}$ Trata-se do baiano João Maurício Wanderley (1815- 89), primeiro e único Barão de Cotegipe. Com longa vida pública, ocupou diversos cargos, entre eles alguns ministérios. Como presidente do Conselho de Ministros (1885- 8) fez aprovar a chamada Lei do Sexagenário, proposta pelo então Conselheiro José Antônio Saraiva. http://www.senado.gov.br/senadores/senadores_biografia.asp?codparl=1819 (acessado em 27/ 09/ 2010).

${ }^{465}$ LACOMBE, Américo Jacobina; SILVA, Eduardo; BARBOSA, Francisco de Assis. Rui Barbosa re a queima dos arquivos. Rio de Janeiro, Fundação Casa de Rui Barbosa, 1988.
} 
de escravos da seguinte maneira: "mais justo seria, e melhor se consultaria o sentimento nacional, se pudesse descobrir meio de indenizar os ex-escravos não onerando o Tesouro" ${ }^{466}$.

Com relação a esse debate, vale salientar alguns pontos. O primeiro deles diz respeito à sua execução. Ao que tudo indica, apesar da assinatura do decreto, isso não implicou na sua efetivação, pois aparentemente foram poucos os atos de incineração produzidos, concretizando-se especialmente nos estados do Rio de Janeiro (1892) e Bahia (1893). Outra questão importante, e que merece uma melhor atenção, é que o ato em si não impossibilitou a pesquisa sobre o tema por parte dos interessados. Isso ocorreu especialmente porque a medida adotada quanto à destruição de documentos dizia respeito apenas ao material existente no Ministério da Fazenda e não em relação às demais instituições públicas ou privadas.

Sendo assim, quando tomado na longa duração, torna-se praticamente impossível o esgotamento do potencial analítico e informativo de um determinado conjunto documental arquivístico, mesmo com suas ausências ${ }^{467}$.

A questão torna-se ainda mais complexa quando levado em conta as instituições de guarda de caráter oficial. Se por um lado esse material auxilia na definição das relações entre governantes e governados, servindo como prova de direitos e privilégios civis, além de prova de propriedade temporal e direitos de ordem financeira, por outro atua como prova da existência de determinados órgãos e ações governamentais. Às instituições públicas cuja função é gerenciar, acumular e disponibilizar toda essa massa documental produzida pelo Estado, caberia tipificar o relacionamento entre governados e governantes, seja na forma com que disponibilizam seu acervo, seja na sua própria composição, permitindo uma auditoria constante dos atos públicos e seu diálogo com a sociedade civil. A análise de todo esse manancial, bem como seu uso por parte dos pesquisadores, poderia

\footnotetext{
${ }^{466}$ Idem.

${ }^{467}$ Vale salientar que, devido ao princípio da organicidade, até mesmo "desfalques" documentais tornam-se facilmente perceptíveis no universo informativo do conjunto arquivístico. Nesse caso, a presença se faz sentir mesmo na ausência.
} 
servir para identificar as diferentes tendências da historiografia, construídas ao longo do tempo ${ }^{468}$.

Esse "controle" em relação aos atos do Estado, produzido por pesquisadores em geral, mostra-se mediada por elementos importantes, relacionados à idéia de representações a serem construídas em determinados tempos históricos, por agentes sociais diversos, imbuídos de estruturas ideológicas próprias. O Brasil possui alguns bons exemplos de ações deliberadas no sentido de se construir memórias/ esquecimentos. Um deles diz respeito à falta de políticas públicas específicas e eficientes relacionadas à área de gestão documental, o que tem levado à inacessibilidade de parcela significativa dos acervos públicos. Esse é o caso do arquivo do Itamaraty, que preserva parte de sua massa documental como sendo de acesso restrito (sigilosa). Com isso, pesquisadores interessados na documentação ali contida têm dificuldades em acessar as fontes, sejam elas vinculadas a temas gerais, ou questões específicas, como a Guerra do Paraguai. Outro exemplo diz respeito à documentação produzida pelos órgãos de segurança durante a ditadura militar. Como cobrar das autoridades a disponibilização ao público da documentação produzida por elas, fazendo valer o artigo $5^{\circ}$ da Constituição (direito ao hábeas data), se não se sabe o que foi produzido?

A restrição ao acesso ou disponibilização de determinados acervos documentais muitas vezes tem por função garantir a honra e a imagem da pessoa humana, assim como a segurança do Estado, conforme estabelece a própria Constituição Federal de 1988. Contudo, por ser comumente confundida como mero mecanismo de sigilo e manipulação, acaba por tornar-se elemento importante na manutenção de segredos/ mentiras. Em um suposto Estado democrático de direito, o

\footnotetext{
468 Comumente, conjuntos documentais são organizados visando sua disponibilização de acordo com a frequiência, ritmo e interesse das pesquisas acadêmicas, seguindo-se calendários comemorativos. Se para escrever história o vínculo com as efemérides pode ser considerado um problema na atualidade, especialmente por reproduzir determinadas versões oficiais, para os arquivos essas festividades podem ser as únicas oportunidades para obtenção de recursos financeiros a projetos aparentemente "pouco vendáveis". Algo muito próximo a isso pode ser percebido quando da comemoração do centenário da imigração japonesa para o Brasil, época em que surgiu interesse e financiamento para a tradução de documentos referentes a esse processo, especialmente as listas de passageiros de navios oriundos do porto de Kobe.
} 
poder público não poderia agir de maneira abusiva, utilizando a informação como ferramenta de dominação. Para Norberto Bobbio,

"não há política sem uso do segredo: o segredo não só tolera como exige a mentira. Ficar preso ao segredo significa ter o dever de não revelá-lo; o dever de não revelá-lo implica o dever de mentir ${ }^{\text {"469 }}$.

Outra questão merecedora de destaque diz respeito à adoção de critérios de seleção e descarte documentais por parte das instituições arquivísticas. As diferenças existentes entre acervos formados por museus, bibliotecas e arquivos são evidentes. Cada uma dessas instituições possui preocupações técnicas distintas, seja na composição de seus acervos, conservação, acondicionamento e disponibilização de suas peças. Contudo, para o público pesquisador pouca diferença faz em qual instituição os documentos serão disponibilizados, sendo que a maior preocupação reside em localizar as informações "úteis" e necessárias.

Talvez aí resida o maior equívoco dos pesquisadores, especialmente porque em conjuntos arquivísticos o volume informacional disponível é maior quando preservado o seu meio genético (organicidade).

Uma das formas adotadas para garantir tal preservação diz respeito ao cumprimento da chamada Teoria das 3 idades, elaborada por Theodore Schellenberg, ainda na década de 1950. Como Vice-Diretor do Arquivo Nacional dos Estados Unidos, seu trabalho reorientou a idéia dos arquivos públicos amparados meramente no princípio "histórico". Neles, a documentação acumulada apoiava-se em épocas históricas e estruturas governamentais e administrativas do passado, inexistindo investimentos no recolhimento sistemático de documentos públicos ou preocupação com as transformações administrativas ocorridas no tempo. Para ele apenas uma parcela da documentação produzida pelos arquivos correntes deveria chegar à terceira idade (arquivos permanente), na medida em que todo o conjunto documental deveria antes passar por processo de avaliação e eventual

\footnotetext{
${ }^{469}$ BOBBIO, Norberto. Elogio da serenidade e outros escritos morais. São Paulo, Editora da Unesp, 2002, p. 208.
} 
descarte. Contudo, para que critérios técnicos eficientes fossem adotados seria necessário que o resultado final mantivesse preservado o princípio de proveniência, garantido por uma organização eficiente da massa documental desde sua fase corrente $^{470}$.

A tarefa de descarte, apesar de pouco agradável aos pesquisadores, tem se mostrado um processamento técnico cada vez mais necessário especialmente devido à implantação de estruturas administrativas cada vez mais burocratizadas, responsáveis por ampliar assustadoramente a produção de documentos ${ }^{471}$.

Com isso, inevitavelmente as peças documentais disponibilizadas ao público passariam antes por processos de seleção, seja pela ação aleatória do tempo, seja seguindo-se mecanismos técnicos de descarte. O mais importante nisso tudo é que, preservada a organicidade, acredita-se que até mesmo as eventuais lacunas documentais existentes não colocariam em risco a reconstrução informacional, visto ser possível restabelecer as presenças pelas ausências, sendo impossível apagar o resíduo da informação deixado no restante do acervo, mesmo que expurgos documentais tenham sido realizados em defesa de interesses individuais ou de grupos $^{472}$, permitindo um diálogo constante e renovado do historiador e as fontes documentais.

\footnotetext{
${ }^{470}$ ARQUIVO NACIONAL. O Arquivo Nacional. Op. Cit. Para uma leitura mais detalhada sobre a questão, ver: SCHELLENBERG, Theodore R. Arquivos modernos: princípios técnicos. Rio de Janeiro, FGV, 2002.

${ }^{471}$ Como o volume documental é cada vez maior, a tarefa de descarte mostra-se inevitável e por isso deve ser feito de maneira ordenada, seguindo-se critérios estabelecidos por um Plano de Gestão Documental (PGD). O Brasil, pioneiro em matéria de legislação sobre arquivos (lei no 8.159/91), entre outras medidas, torna ilegal o descarte de documentos públicos sem previa avaliação e aprovação dos órgãos competentes, por meio de suas Comissões de Avaliação, responsáveis por avaliar, publicar edital de ciência de eliminação (periódicos oficiais) e eliminar documentos (produzir relação de eliminação). Sua principal ferramenta de ação seria a Tabela de Temporalidade (aprovada por autoridades competentes) que orienta o arquivista quanto aos prazos legais de guarda intermediária, para daí estabelecerem-se possíveis descartes ou recolhimentos. Para maiores informações vale a leitura de: BERNARDES, Ieda Pimenta. Como avaliar documentos de arquivo. São Paulo, Arquivo do Estado de São Paulo/ Imesp, 1998. Também vale a leitura das resoluções técnicas estabelecidas pelo Conselho Nacional de Arquivos (Conarq), em: http://www.conarq.arquivonacional.gov.br/cgi/cgilua.exe/sys/start.htm (acessado em 28/ 09/2010)

${ }^{472} \mathrm{O}$ conjunto documental produzido/acumulado pelo DEOPS- SP (Departamento Estadual de Ordem Política e Social) pode servir de exemplo para essa ponderação visto ter sido este um órgão que passou por transformações internas importantes, mudando seu perfil conforme a mudança do regime político vigente, mas sem nunca perder de vista seu papel de vigilância. Além disso, seu acervo "viveu" algum tempo sobre o controle da Polícia Federal, num híbrido de controle e fiscalização em tempos de redemocratização. Ao que parece, mesmo que determinadas informações tenham sido deliberadamente "apagadas", mediante a retirada
} 
No caso do acervo pertencente à $3^{\circ}$ seção da Repartição de Estatística e Arquivo de São Paulo, algo semelhante aconteceu. Tratava-se de um grande volume de documentos, preservados a duras penas, com o intuito de subsidiar a governança paulista desde o tempo colonial, com todas as idas e vindas administrativas em relação à autonomia da Capitania ${ }^{473}$. Por necessidade administrativa, durante o Império inúmeras comissões foram nomeadas pelo governo provincial visando organizar esse acervo, produzido/acumulado pela Secretaria de Governo. Apesar de nenhuma delas ter chegado a lavrar qualquer tipo de registro relacionando o material descartado, nos relatórios anuais de atividades do governo constam a saída de "grande número de carroças cheias de papéis, sem o necessário exame e julgados pelas mesmas inúteis, para serem incinerados" ${ }^{\prime 474}$.

Mesmo após a constituição oficial da Repartição (1892) pouca coisa foi alterada nessa questão. Ainda nesse ano uma correspondência oficial emitida pela própria Repartição acusava o recebimento de dinheiro decorrente da venda de papéis inúteis do Arquivo ${ }^{475}$, que nada mais eram que documentos da extinta Secretaria de Governo e que não serviriam à nova ordem administrativa vigente.

Em 1904, em relatório produzido pela Secretaria do Interior, a quem a Repartição estava vinculada, e apresentado ao governo do Estado, mostrava-se a necessidade de classificação e liberação eventual de documentos, cabendo ao Diretor a atribuição de

"destruir, sem dano para a história ou para a administração, aquilo que não mereça ficar na Repartição, tomando-lhe inutilmente o espaço, sempre, porém com o voto de uma comissão, nomeada pelo Governo do Estado, para julgar a oportunidade da medida" ${ }^{, 476}$.

\footnotetext{
de documentos do acervo, a integridade dessa massa documental foi mantida, não representando perda informacional significativa para o público interessado, seja ele o historiador ou o cidadão em busca de direitos.

${ }^{473}$ Para maiores informações, ver Capítulo I.

474 AESP. Histórico do archivo público de São Paulo; acompanhado da relação dos cidadãos que governaram a província e o estado. São Paulo, Duprat, 1908, p. 12.

${ }^{475}$ Acervo AESP. Repartição de Estatística e Arquivo (protocolo de correspondências), E 01433 (nº 29, p. 04, de 14 de dezembro de 1892).

${ }^{476}$ GOVERNO DE SÃO PAULO. Relatório da Secretaria dos Negócios do Interior. São Paulo, Tipografia do Estado de São Paulo, 1904, p. 179.
} 
Diversas iniciativas de triagem da documentação merecedora de guarda foram levadas a cabo durante os primeiros anos de existência da Repartição, separando-se o "joio do trigo". Após a morte de Antonio de Toledo Piza (1905), mais uma comissão fora nomeada para realizar triagem nos papéis acumulados nos depósitos do Arquivo e incinerar aqueles considerados inúteis (1906) ${ }^{477}$. Em relatório apresentado ao Sr. Jorge Tibiriçá enquanto este governava São Paulo, Gustavo Godoy, Secretário do Interior, apresentou a seguinte afirmação:

"O Archivo, depositário das tradições históricas, políticoadministrativas de São Paulo, desde os tempos coloniais até os nossos dias, melhorou sensivelmente com a nova sede. No intuito de expurgá-lo da grande quantidade de papéis sem valor e utilidade nele existentes, foi nomeada uma comissão encarregada de selecionar cuidadosamente todos os papéis e documentos que por sua natureza e antiguidade interessam à história política e administrativa nacional e do Estado ou sejam de interesse público ou privado.

Essa comissão já fez incinerar grande cópia de papéis completamente inúteis e continua a trabalhar com atividade no desempenho de sua incumbência; dos papéis inutilizados, fica constando a respectiva relação em acta lavrada pela comissão." 478

Tal procedimento objetivava garantir maior eficiência nos trabalhos de guarda, organização e disponibilização das informações. Sendo assim, o próprio Diretor da Repartição, por meio de relatório encaminhado ao Secretário do Interior, defendia uma intervenção rápida e eficiente de seu corpo técnico junto ao acervo,

\footnotetext{
${ }^{477}$ Essa comissão era composta por Adolpho Botelho de Abreu Sampaio (Presidente), Anselmo de Carvalho, Antonio Egydio Martins (Secretário) e Eugênio de Andrade Egas. Acervo AESP. Secretaria do Interior, C 7010, ofício de 19 de março de 1906. Uma outra comissão para seleção de documentos foi nomeada em 09 de dezembro de 1927, responsabilizando-se pela eliminação de 14 toneladas de material. Aparentemente esse procedimento contou com a confecção de relações diárias encaminhadas ao Secretário do Interior. AESP. Boletim do Departamento do Arquivo do Estado de São Paulo. São Paulo, Departamento de Arquivo, 1952, vol. IX.

${ }^{478}$ GOVERNO DE SÃO PAULO. Relatório da Secretaria dos Negócios do Interior. São Paulo, Tipografia do Estado de São Paulo, 1907, p. 62.
} 
visto que a $3^{\mathrm{a}}$ seção era vista "antes [como] um amontoado de papéis, em grande parte inúteis, cuja seleção se impõe com urgência" ${ }^{\text {"479. }}$.

Durante essa pesquisa não foi localizado nenhum livro de ata acerca do material expurgado. Contudo, em ofícios encaminhados pelo então Diretor da Repartição de Estatística e Arquivo, Sr. Adolpho de Abreu Sampaio, foi relacionado, genericamente, todo o material eliminado mediante incineração junto às dependências do Desinfectório Central. As pessoas nomeadas para essa finalidade deveriam expurgar tudo aquilo que fosse considerado documento sem valor e utilidade "à história política e administrativa nacional e do Estado ou sejam de interesse público ou privado" ${ }^{480}$. Tratavam-se de boletins e mapas apurados de escolas públicas (com exceção dos ofícios, pertencentes ao arquivo da extinta Secretaria da Instrução Pública), maços de papéis acumulados pela antiga Secretaria de Governo da Província (ofícios, relações, mapas e atas referentes à escravidão, ofícios e balancetes das Mesas de Renda e Barreiras, mapas diários do corpo policial, mapas de férias de trabalhadores das obras públicas), mapas de recenseamento, 497 carta patentes de oficiais da Guarda Nacional, atas das sessões da Assembléia Legislativa Provincial, boletins de movimento de imigrantes, jornais e revistas de diferentes anos e localidades (alegavam estarem estragados pela ação da umidade), relatórios, coleções de leis e decretos e publicações oficiais de São Paulo e outros estados (também danificados pela umidade) ${ }^{481}$. De acordo com a própria comissão, parte desse material teria sido selecionado e considerado inútil pelo próprio Toledo Piza ${ }^{482}$.

Por um lado, a eliminação de mapas de recenseamento confeccionados pela própria Repartição pouco traria de prejuízo ao conhecimento futuro das ações do poder público, visto que as informações contidas nesse material, provavelmente, já teriam sido sistematizadas em outros documentos, até mesmo publicações. Tal

\footnotetext{
${ }^{479}$ Ibidem.

${ }^{480}$ Ibidem.

${ }^{481}$ Acervo AESP. Secretaria do Interior, C 7010. Tratam-se de 8 ofícios assinados por Adolpho de Abreu Sampaio e destinados a Gustavo de Oliveira Godoy, entre os dias 19 de março e 11 de outubro de 1906.

${ }^{482}$ Acervo AESP. Secretaria do Interior, C 7010, ofício de 01 de maio de 1906.
} 
afirmação torna-se possível quando avaliado o próprio discurso da Repartição acerca do poder informativo e potencial de uso desse material. Para o próprio Abreu Sampaio esses dados estatísticos seriam,

"além de elementos indispensáveis à administração, seria valioso instrumento de propaganda de suas condições naturais para a grande imigração e povoamento do solo, assim como para atrair a inteligência e o capital estrangeiro" ${ }^{483}$.

O mesmo não pode ser dito sobre toda a massa documental referente ao tema “escravidão". Vale salientar que, em todos os ofícios encaminhados ao Secretário do Interior referentes a essas eliminações aparece sistematicamente a referência a esse tipo de documento. Se por um lado poderia tratar-se de peças com significativo teor explicativo, por outro, seria plausível a suposição de ser apenas material inutilizado pela própria ação do tempo. Contudo, caberia aqui mais um questionamento. Se o material encontrava-se danificado pela ação da umidade (problema comum enfrentado no Arquivo), por que essa documentação foi alvo de danificação sistemática? Se isso realmente ocorreu, e não houve nenhuma tentativa deliberada de apagamento de uma determinada memória, tal colocação aponta para a condição de descaso em que esse material estava entregue durante boa parte da existência do órgão. $\mathrm{O}$ intrigante é que se tratava sempre do mesmo tipo de documento, o que aponta para um possível descaso "proposital" $"$.

Além disso, uma análise que levasse em conta a totalidade do material recolhido à Repartição apontaria para uma determinada intencionalidade. Em um balanço "oficial" do acervo realizado em 1908, foi enumera parcela dos conjuntos documentais existentes no Arquivo, sendo eles:

"Além da grande quantidade de maços de papéis, Mapas de População de 1765 a 1822 e de 1823 a 1846, Livros mestres

\footnotetext{
${ }^{483}$ GOVERNO DE SÃO PAULO. Relatório da Secretaria dos Negócios do Interior. São Paulo, Tipografia do Estado de São Paulo, 1907, p. 63.

484 Apenas para ilustrar, em relatório encaminhado pelo Diretor do Arquivo em 1926 era registrada a reclamação a respeito das péssimas condições de preservação dos documentos referentes à Secretaria de Justiça, que teriam sido levados provisoriamente ao Arquivo, encontrando-se "amontoados no assoalho, estragando-se por completo". Acervo AESP. Repartição de Estatística e Arquivo (relatórios), E 12033, p. 14.
} 
de militares de 1765 a 1821 e os Livros de Registro de Patentes, Provisões e Cartas de Sesmaria e da Correspondência do Governo do tempo colonial e que ainda não foram publicados, existem também, no Arquivo Público, guardados, nas respectivas estantes, diversos maços de papéis do tempo do Império, o Livro de Atas das sessões da Junta do Governo Provisório de 1821 a 1822 e o das Atas do Conselho do Governo de 1828 a 1830; os Autógrafos das cartas de Leis Provinciais de 1835 a 1889; Dito da Constituição do Estado promulgada, pelo Congresso Constituinte, em data de 14 de julho de 1891; Ditos dos Decretos e Resoluções do Governo Provisório de 18 de outubro de 1890 a 30 de junho de 1891; Ditos das Leis e Decretos Estaduais de 1891 a 1906; os Livros de Registro da Correspondência e Atos do Governo Provisório de 1823 a 1824 e os dos Presidentes e VicePresidentes da Província de São Paulo desde 1824 até 1889, e bem assim os Livros de Registro de Terras do tempo do Império, Decretos e Cartas Imperiais e os originais dos Avisos dos Ministérios do Império, Justiça, Fazenda, Estrangeiros, Agricultura, Comércio e Obras Públicas, Marinha e Guerra de 1822 a 1889; os papéis e livros da extinta Secretaria da Instrução Pública, das atuais Secretarias de Estado dos Negócios do Interior e da Justiça e Segurança Pública e da Inspetoria Geral do Ensino de 1898 a 1903 e grande número de maços de autos cíveis, crimes e de inventários desta Capital e de Sorocaba, processados nos séculos XVI, XVII e XVIII, assim como os processos criminais do Cartório do $1^{\circ}$ Escrivão do Júri desta Capital, os quais, em virtude do que determina a Lei $\mathrm{n}^{\circ}$ 666, de 6 de setembro de 1899, foram recolhidos ao Arquivo Público.

(...) Também existem, no Arquivo Público, depositados grande número de exemplares impressos de Leis Provinciais, Estaduais, Regulamentos, Relatórios e outras publicações oficiais" ${ }^{\prime 45}$.

$\mathrm{Na}$ ocasião, tais elementos foram elencados pois coube à Repartição efetuar outro recolhimento referente de documentos administrativos do Estado. Tratava-se de relatórios, minutas de ofícios, registros de atos diversos e telegramas, cobrindo o período que ia de 1874 a 1891 . Aparentemente o processo tornou-se comum e, recorrentemente, conjuntos documentais eram enviados para a Repartição. Em 1910 um grande volume de material referente aos anos de 1881 a 1893, produzidos pela

${ }^{485}$ AESP. Histórico do archivo público de São Paulo. Op. Cit., pp. 7-8. 
Secretaria da Agricultura, Comércio e Obras Públicas foi incorporado ao acervo, sendo eles dotados de descrição unitária ${ }^{486}$.

Outros exemplos dessa iniciativa ocorreram durante a década de 1920. Em 1922 o então Diretor do Arquivo encaminhava um relatório apontando para a entrada na instituição de documentos oriundos da Secretaria do Interior, além de diversas publicações para sua biblioteca ${ }^{487}$.

Apesar dos constantes recolhimentos, e ampliação da massa documental disponível ao público consulente, a questão do descarte ainda causará polêmica entre arquivistas e pesquisadores, especialmente em um país corriqueiramente acusado de não "preservar sua memória", mesmo sendo ele um ato técnico, capaz de agregar aos acervos arquivísticos um caráter absolutamente único na ação dialética de construção de representações.

Na opinião de José Sebastião Witter, o dilema residiria em como selecionar o que deveria ser preservado ou eliminado. Para ele,

$$
\begin{aligned}
& \text { "tudo pode ser considerado História e documentos } \\
& \text { insignificantes hoje podem se constituir em peças } \\
& \text { fundamentais amanhã. Mas, não se pode, evidentemente, } \\
& \text { manter tudo o que se produz hoje e assim a opção se } \\
& \text { impõe" } " \text {. }
\end{aligned}
$$

Apesar da impossibilidade de se preservar todos os documentos produzidos pelo Estado, em suas mais diferentes instâncias, o processo de desburocratização não deveria passar pela ativação inconseqüente de comissões de descarte dos “desnecessários papéis velhos" "489. Em sua opinião, "quanto documento já deve ter sido destruído, quer pelos processos de maceração, quer pela incineração, em nome

\footnotetext{
${ }^{486}$ Acervo AESP. Repartição de Estatística e Arquivo (relação de remessa), E 12032. Trata-se de material encaminhado entre os dias 17 de outubro e 23 de dezembro de 1910.

${ }^{487}$ Nessa mesma ocasião, o Diretor relatou o envio de 135 volumes de documentos para serem encadernados na Penitenciária do Estado. Acervo AESP. Repartição de Estatística e Arquivo (relatórios), E 12033.

${ }^{488}$ WITTER, J. S. Arquivo e história. O Arquivo do Estado de São Paulo. Op. Cit., p. 13.

${ }^{489}$ Idem, p. 38.
} 
de uma agilidade no processo de arquivamento"490. Contudo, a não adoção de mecanismos técnicos adequados que possam orientar a eliminação, e por tanto a preservação da documentação "restante", acabaria por permitir o desaparecimento de grandes massas documentais, especialmente pelo descaso por parte daqueles que deveriam preservá-la.

Com tudo isso fica claro não se poder atribuir aos arquivos o caráter de detentores da "verdade histórica", disponibilizando informações neutras e inquestionáveis. Como visto anteriormente, não se pode deixar de lado todos os elementos vinculados à própria composição dos acervos que, em certa medida, já apresentaria um caráter tendencioso, seja no perfil de seu material, seja pelos diferentes mecanismos de descarte ocorridos ao longo do tempo. Além disso, caberia ao público pesquisador o estabelecimento das ilações possíveis dentro de um determinado cenário temporal.

Mesmo assim, para o efetivo ofício do historiador, a riqueza dos arquivos mostra-se como algo inquestionável e de potencial ilimitado, permitindo "que a História seja reinterpretada, que não se fossilize"491. Para isso é preciso que o pesquisador estabeleça um novo olhar sobre o documento de forma a romper com a colonialidade do saber, especialmente acadêmico. Em uma dura crítica, Boris Fausto ataca parte dos historiadores por alimentarem uma tendência à repetição e reprodução de informações, muitas vezes por mero comodismo, reafirmando interpretações "como verdade sabida, não suscetível de discussão" ao que de "pior" poderia persistir do chamado positivismo.

\footnotetext{
${ }^{490}$ Ibidem.

${ }^{491}$ FAUSTO, Boris. "Comentário". In: INSTITUTO FERNANDO HENRIQUE CARDOSO. Documentos privados de interesse público: o acesso em questão. São Paulo, IFHC, 2004.

${ }^{492}$ Idem.
} 


\section{Capítulo 4}

\section{Considerações Finais}

Diferentemente daquilo que era preconizado como prática dos arquivos em pleno séc. XIX, atualmente as instituições de guarda documental vêm demonstrado grande preocupação quanto à preservação de conjuntos organicamente acumulados, capazes de atender tanto aos interesses dos pesquisadores como servirem de prova da existência administrativa de determinados órgãos e ações, muitas vezes públicas, auxiliando no desempenho de suas funções cotidianas. Inegavelmente, documentos não são produzidos para atender a uma demanda de pesquisa, mas sim, para cumprirem funções burocrático-administrativas definidas.

Sendo assim, apesar de todo seu caráter técnico, instituições como a Repartição de Estatística e Arquivo possuíam grande responsabilidade quanto à construção da imagem que o poder público visava preservar sobre si e seu envolvimento nos embates sociais. Intervenções como o descarte documental e a escolha de peças a serem publicadas, de maneira seriada ou isoladamente, tipificam o posicionamento ideológico adotado pelo poder constituído.

Uma visão mais contemporânea acerca da importância das instituições arquivísticas as vincula diretamente à administração, deixando em segundo plano seu caráter de atendimento ao público pesquisador no tocante a questões culturais ou históricas. Na opinião de Ana Maria Camargo caberia aos arquivos a reconstituição da lógica administrativa, seja do Estado, seja de instituições privadas, por meio da documentação por ela produzida/acumulada. Para ela, o arquivista não deveria interferir na organização de um acervo feita por sua instituição geradora, mas sim, conhecê-la profundamente "para poder imprimir qualidade ao fluxo dos documentos que a viabilizam". Contudo, diante um conjunto de documentos desorganizados, 
cuja função primária já tenha esgotado, caberia ao arquivista devolver-lhes a “configuração original, perfeitamente ajustada ao modus faciendi da entidade" ${ }^{493}$.

Contudo, os arquivos públicos, especialmente o Arquivo do Estado de São Paulo, foco deste trabalho, acabaram ampliando suas funções e direcionando parcela de suas atenções mais ao atendimento aos anseios advindos do público pesquisador do que à gestão documental propriamente dita. Em muitos casos, as iniciativas dos próprios pesquisadores é que direcionaram intervenções técnicas junto aos acervos, contando com a chancela da própria instituição, mas sem nenhuma participação direta de seu corpo técnico. Em outros, conjuntos documentais fragmentados foram reproduzidos digitalmente e disponibilizados, seguindo-se os mesmos "critérios" estabelecidos na série Documentos interessantes desde o final do séc. XIX e boa parte do séc. XX. Assim, acredita-se e divulga-se que a instituição seria a própria detentora de parcela significativa da "memória paulista", sem levar em conta seu caráter de constante transformação.

$\mathrm{Na}$ opinião de muitos, o simples fato de se preservar documentos antigos, mesmo que de maneira descontextualizada, já lhes atribuiria valor de guarda, pois afinal, seriam manifestações verdadeiras de um passado acabado e pronto para ser contado em sua totalidade. Contudo, o que muitos não percebem é que tão impactante quanto o estabelecimento de critérios que levam à preservação de um determinado conjunto patrimonializado são os motivos que acarretam na destruição do restante. Ideologicamente, as mesmas forças que motivam a preservação podem atuar diretamente na destruição (como nos casos do muro de Berlim ou os budas no Afeganistão), tornando a demolição, ou o descarte, tão representativo quanto a preservação. Ao analisar o caso europeu, Françoise Choay apontou para os movimentos de destruição de antigos monumentos feudais. Para ela não se tratava de mero vandalismo, mas sim fruto de um ato que se propunha cívico e patriótico. Algo semelhante teria acontecido com a Bastilha. Em seu lugar original fora

\footnotetext{
${ }^{493}$ CAMARGO, Ana Maria de Almeida. "Por um modelo de formação arquivística". In: Ciências e letras. Porto Alegre, nº 31, jan- jun 2002, p. 193.
} 
construída uma praça, não sendo cogitada a preservação do prédio fosse por seu valor arquitetônico, fosse por uma eventual reutilização simbólica, mesmo que para outros fins. Assim, souvenirs foram distribuídos por toda a França, confeccionados a partir de pedras retiradas da estrutura da prisão. Muitas delas eram compradas em formato de medalhão, cravados com brilhantes onde podia ser lido "Liberdade"494.

A grande diferença para o caso dos conjuntos documentais arquivísticos é que até mesmo quando parcela da documentação é descartada, deveria ser possível preservar e recuperar seu caráter orgânico. Assim, esses mesmos documentos passariam a ser "reflexos (ou evidências)" das mesmas atividades que o geraram, adquirindo significado apenas quando levado em conta as atividades realizadas. Nas palavras de André Ancona Lopes, seria o princípio da organicidade o responsável por estabelecer a compreensão dos "documentos agrupados em séries, de acordo com as atividades responsáveis por sua geração", deixando-se de lado a "idéia de documento único ou de peças individualizadas" ${ }^{495}$.

Com isso, as coleções, dissociadas de seus organismos produtores, permitiriam menores possibilidades de compreensão dos mesmos documentos, valorando-se apenas seu conteúdo intrínseco e impedindo sua categorização como arquivo. Se, por um lado, o documento de arquivo mostra-se como resultado de uma vontade administrativa, amparada em uma "determinada concepção de mundo", por outro ele se coloca como "vetor tanto de novas ações administrativas, como do entendimento do real" ${ }^{\prime 496}$.

Inegavelmente, em um primeiro momento, um documento tem "a função administrativa de indicar que a atividade deverá ser executada, por qual motivo e por quem". Contudo, é equivocado concluir, assim como fez André Ancona Lopez que, uma vez cumprida essa função, "a permanência do documento ocorre como uma prova da execução das atividades, mostrando para o pesquisador quem fez o que e

${ }^{494}$ CHOAY, Françoise. Alegoria do patrimônio. São Paulo, Estação Liberdade/ Editora da Unesp, 2001.

${ }^{495}$ LOPEZ, André Ponto Ancona. As razões e os sentidos. São Paulo, Tese de Doutorado defendida no Departamento de História da Faculdade de Filosofia, Letras e Ciências Humanas da Universidade de São Paulo, 2000, p. 14.

${ }^{496}$ Idem, p. 39. 
por quais motivos ${ }^{\$ 497}$. Valem aqui algumas ressalvas. Em primeiro lugar, o acúmulo de determinados conjuntos documentais, mesmo que preservada a organicidade, não garantem que tais atividades tenham sido efetivamente executadas. Como apontou Caio Prado Jr., a existência de um sem número de decretos imperiais nos arquivos portugueses sobre a proibição da escravidão indígena no Brasil, seria um forte indício de que tal determinação nunca fora cumprida, apesar das preocupações da administração portuguesa ${ }^{498}$. Além disso, a eventual inexistência de ofícios remetidos por aquelas autoridades em terras brasileiras à Coroa, sobre as dificuldades de implantação dessa medida, não permitiria a conclusão de inoperância e concupiscência dessas mesmas autoridades frente aos interesses da elite local. Um segundo ponto que merece destaque diz respeito à própria preservação de um conjunto documental. Por mais criteriosa que seja a teoria arquivística no tocante ao descarte, inegavelmente a preservação de determinados conjuntos, em detrimento de outros, ocorre muitas vezes de maneira aleatória, quando não "criminosa", permitindo a degradação sistemática de conjuntos documentais devido ao total descaso das autoridades competentes. Este talvez tenha sido o caso dos documentos sobre escravidão, sistematicamente descartados pela Repartição de Arquivo em 1908 devido ao seu péssimo estado de conservação ${ }^{499}$. Se o ato de arquivar tem por finalidade "provar atividades realizadas", resta saber sob quais interesses repousa tal prova pois, assim como a preservação, a destruição também apresenta forte caráter ideológico.

Apenas para estimular a reflexão sobre tal situação, no ano de 2001 o Arquivo do Estado entrou em contato com a Fundação SEADE (Sistema Estadual de Análise de Dados) ${ }^{500}$ para que ela estabelecesse destinação a um conjunto documental sob custódia intermediária no Arquivo. Tratavam-se dos "Boletins Individuais" (B.I.s), criado pelo Código de Processo Penal (artigo 809) e

\footnotetext{
${ }^{497}$ Idem, p. 61.

${ }^{498}$ PRADO JR, Caio. Formação do Brasil contemporâneo. São Paulo, Brasiliense, 1996.

${ }^{499}$ Para maiores informações, ver Capítulo III.

${ }^{500}$ Criada em 1978, tornou-se de responsabilidade da Fundação a execução de estatísticas criminais, policiais e judiciais em todo o estado de São Paulo.
} 
regulamentado pelo decreto-lei 3.992/41, vigentes a partir de 1 de janeiro de 1942. Originalmente, esse documento era composto de três partes, sendo as duas primeiras preenchidas ainda pelas delegacias de polícia, após o término do inquérito. A primeira delas deveria ficar arquivada no cartório policial e a segunda, remetida ao órgão responsável pelas estatísticas policiais de cada estado. Uma terceira via seguia com o inquérito, para ser preenchida quando transitado em julgado o processo, sendo então remetida aos órgãos estaduais de estatística. Uma vez apuradas as estatísticas, as segundas e terceiras vias dos B.I.s deveriam ser encaminhadas ao Instituto de Identificação do Estado - no caso de São Paulo o Instituto de Identificação Ricardo Gumbleton Daunt, que iniciou suas atividades em 1907 ainda com outra denominação - para auxiliar na emissão de folhas e atestados de antecedentes.

Em Relatório de avaliação e descarte apresentado ao SEADE em 2001 pela historiadora Mônica Duarte Dantas, constatou-se a existência de um acervo composto por mais de 500 caixas de B.I.s, estando 34 delas na própria Fundação e outras 481 no Arquivo do Estado, em seu setor Intermediário. Porém, por meio de convênio assinado em 1991, o Núcleo de Estudos da Violência (NEV) da Universidade de São Paulo recebera 110 caixas de B.I.s para a realização de uma pesquisa sobre criminalidade. Por meio de outro convênio, assinado em 1994, o NEV recebeu outras 292 caixas de B.I.s, agora oriundas diretamente do Poder Judiciário. Ao que parecia, a data-limite do material percorria o período de 1973 a 1999. A dificuldade em estabelecer análises precisas sobre qualquer um desses dados residia no fato de ser impossível uma averiguação mais detalhada em relação à documentação sob guarda do NEV. O motivo disso é que todo o material fora, simplesmente, descartado sem passar por nenhum processo de avaliação técnica.

De acordo com relatos de antigos funcionários do Núcleo, em 1995 o NEV recebeu um ofício da Reitoria da Universidade pedindo que, frente à necessidade de reforma do galpão onde estavam guardados os B.I.s, se manifestasse quanto a 
necessidade de guarda ou a possibilidade de descarte da documentação, como o NEV não se manifestou, os B.I.s foram incinerados.

Para muitos, a melhor forma de solucionar tais desencontros seria a implantação de políticas de reprodução, especialmente por meio digital, divulgando todo esse material na rede mundial de computadores. Na prática, apesar de incorporar mecanismos inovadores em termos tecnológicos, tal atitude nada mais representaria que a reedição da publicação Documentos interessantes, adotando-se critérios pautados muito menos em questões técnicas e mais em vontades políticas. Assim, caberia ao Arquivo do Estado, mais uma vez, reeditar sua auto-imagem, agora menos preocupado com as questões técnicas da arquivística e mais voltado à confecção de uma história fragmentada e ligada a efemérides.

Quando em 1894 a Repartição de Estatística e Arquivo, sob direção do Sr. Antonio de Toledo Piza, iniciou a publicação dos Documentos interessantes, visava atender a uma demanda do público pesquisador, custodiado principalmente no Instituto Histórico e Geográfico de São Paulo (IHGSP), criando uma fonte segura e rápida para a obtenção de documentos originais transcritos e valorados como “importantes" pela própria instituição. Conforme apontado anteriormente, durante os 11 anos de administração de Toledo Piza foram publicados quase 50\% de todos os volumes disponibilizados pela coleção. Contudo, mesmo com seus lapsos temporais, a série permaneceu sendo editada pelo Arquivo do Estado até 1990, sempre mantendo o mesmo perfil editorial. $\mathrm{Na}$ prática, os documentos selecionados adquiriam um caráter muito mais museal do que de peça documental administrativa produzida de maneira contextualizada, para atender a uma demanda burocráticoadministrativa.

Com tudo isso, espero que esse trabalho permita ao leitor ter uma percepção mais complexa sobre os Documentos interessantes, diferentemente daquela que eu tinha enquanto estava vinculado ao Arquivo do Estado e não era capaz de perceber a relevância de uma publicação tão extensa, possuidora de uma aparente fragmentação cronológica e temática. Espero também que tenha conseguido esclarecer os 
mecanismos estabelecidos pela instituição no tocante à construção de sua identidade, mantendo um posicionamento capaz de consolidar a imagem pioneira de São Paulo quanto ao desenvolvimento econômico e cultural do país. 


\section{Referências}

\section{Acervos Consultados}

Arquivo do Estado de São Paulo (AESP)

Biblioteca do Instituto de Estudos Brasileiros (IEB)

\section{Fontes}

ARQUIVO DO ESTADO DE SÃO PAULO. Documentos interessantes para a história e costumes de São Paulo. São Paulo, Casa Eclética, vol. 01- 92, 18941978.

. Histórico do archivo público de São

Paulo; acompanhado da relação dos cidadãos que governaram a província e o estado. São Paulo, Duprat, 1908.

. Inventários e testamentos. São Paulo,

Departamento de Arquivo, vol. 01- 47, 1920- 1999.

. Sesmarias. São Paulo, Departamento

de Arquivo, vol. 01- 06, 1921- 1944.

- Catálogo da secção histórica do

departamento do Arquivo do Estado de São Paulo. Rio de Janeiro, Oficina Gráfica do Arquivo Nacional, 1939.

. Boletim do Departamento do Arquivo

do Estado de São Paulo. São Paulo, Departamento de Arquivo, vol. 01- 16, 1945- 1962.

. Documentos avulsos. São Paulo,

Departamento de Arquivo, vol. 01- 06. 1952- 1955. 
. Pequeno histórico e prontuário do

Departamento do Arquivo do Estado. São Paulo, Departamento do Arquivo do Estado, 1953. . Crônica dos diretores do Arquivo. São

Paulo, Arquivo do Estado, 1984. . Registro de terras. Departamento de

Arquivo, vol. 01- 05, 1984- 1999. . Guia do acervo. São Paulo, Arquivo

Estado/ Imprensa Oficial, 1997.

GOVERNO DE SÃo PAUlO. Relatório do Presidente da Província. São Paulo, Tipografia Jorge Secker, 1881- 87.

- Relatório da Secretaria dos Negócios do Interior.

São Paulo, Tipografia Vandorden, 1892- 1912.

- Relatório da Repartição de Estatística e Arquivo.

São Paulo, Tipografia Leuzinger, 1935- 39.

. Relatório do Departamento de Arquivo do Estado de

São Paulo. São Paulo, Imprensa Oficial, 1935- 53.

. Coleção de leis e decretos do estado de São Paulo.

São Paulo, Imprensa Oficial, 1958.

INSTITUTO HISTÓRICO E GEOGRÁFICO BRASILEIRO. Memórias do instituto histórico e geographico brasileiro. Rio de Janeiro, Tipografia de Laemmert, 1839.

INSTITUTO HISTÓRICO E GEOGRÁFICO DE SÃO PAULO. Revista do Instituto Histórico e Geográfico de São Paulo. São Paulo, IHGSP, vol. 01- 88, 1895- 1993.

\section{Conjuntos documentais pertencentes ao acervo permanente do AESP}

Departamento do Arquivo do Estado (1906- 67). 
Divisão de Arquivo do Estado (1842- 1998).

Repartição de Estatística e Arquivo (1830-1950).

Secretaria do Interior - Estatística e Arquivo (1892-1915).

\section{Bibliografia}

ALVES, Ana Maria de Alencar. O Ipiranga apropriado: Ciência política e poder. $O$ Museu Paulista 1893- 1922. São Paulo, Humanitas/FFLCH-USP, 2001.

AMARAL, Antônio Barreto do. $O$ departamento de arquivo do estado e sua história. São Paulo, DAESP, 1974.

AMED, Fernando. As cartas de Capistrano de Abreu. São Paulo, Alameda, 2006.

ARANTES, Antonio Augusto. Produzindo o passado. Estratégias de construção do patrimônio cultural. São Paulo, Brasiliense, 1984.

ARQUiVO DO ESTADO DE SÃO PAUlO. Crimes em São Paulo. Catálogo de fundos dos juízos da Capital existentes no Arquivo do Estado de São Paulo. São Paulo, Arquivo Estado/ Imprensa Oficial, 1998.

ARQUIVO NACIONAL. Manual de levantamento da produção documental. Rio de Janeiro, Publicações Técnicas, 1986.

- Proposta para um programa de modernização dos sistemas arquivísticos dos países latino-americanos. Rio de Janeiro, Publicações Técnicas, 1988. . O Arquivo Nacional: 1838- 2004. Rio de Janeiro, Arquivo

Nacional, 2004.

http://www.portalan.arquivonacional.gov.br/Media/Catalogo\%20Institucional. pdf, acessado em 22/ 06/ 2009.

AZEVEDO, Cecília (org.) et al. Cultura política, memória e historiografia. Rio de Janeiro, FGV, 2009.

BARAN, Paul; SWEEZY, Paul. Capitalismo monopolista. Rio de Janeiro, Zahar, 1966. 
BARBUY, Heloísa. A exposição universal de 1889 em Paris. São Paulo, Loyola, 1999. . A cidade-exposição. Comércio e cosmopolitismo em São Paulo, 1860- 1914. São Paulo, 2006.

BELLOTTO, Heloísa Liberalli. “Arquivologia: objetivos e objetos”. In: Arquivo: boletim histórico e informativo. São Paulo, Arquivo do Estado de São Paulo, v. $10, \mathrm{n}^{\mathrm{o}} 2, \mathrm{jul} / \mathrm{dez} 1989$.

- "Da administração à história: ciclo vital dos documentos e função arquivística". In: Arquivos permanentes: tratamento documental. São Paulo, T. A. Queiroz, 1991.

. "A profissão e o ensino da arquivologia". In: Boletim do Arquivo. São Paulo, Arquivo do Estado de São Paulo, v. 01, nº 1, dez 1992. . Arquivística: objetos, princípios e rumos. São Paulo, Arq-SP, 2002. Arquivos permanentes: tratamento documental. Rio de Janeiro, Editora FGV, 2004.

BERBEL, Márcia. "Pátria e patriotas em Pernambuco (1817- 1822): não, identidade e vocabulário político". In: JANCSÓ, István. Brasil: formação do estado e da nação. São Paulo, Hucitec, 2003.

BERNARDES, Ieda Pimenta. Como avaliar documentos de arquivo. São Paulo, Arquivo do Estado de São Paulo/ Imesp, 1998.

BLOCH, Marc. Apologia da história ou o ofício do historiador. Rio de Janeiro, Jorge Zahar Editor, 2001.

BOBBIO, Norberto. Elogio da serenidade e outros escritos morais. São Paulo, Editora da Unesp, 2002.

BOSI, Alfredo. "O tempo e os tempos". In: NOVAES, Adauto (org.). Tempo e história. São Paulo, Companhia das Letras/ Secretaria Municipal de Cultura, 1992.

BOSI, Eclea. Memória e sociedade. São Paulo, Companhia das Letras, 1994. 
BRAUDEL, Fernand. Escritos sobre a história. São Paulo, Perspectiva, 1978.

BREFE, Ana Claudia Fonseca. O Museu Paulista: Affonso de Taunay e a memória nacional. São Paulo, Editora da Unesp/ Museu Paulista, 2005.

BURKE, Peter (org.). A escrita da história: novas perspectivas. São Paulo, Editora da Unesp, 1992.

CALDEIRA, João Ricardo de Castro. IEB: origem e significado. São Paulo, Oficina do Livro/ Imesp, 2002.

CAMARGO, Ana Maria de Almeida. A imprensa periódica como objeto de instrumento de trabalho: catálogo da hemeroteca Júlio de Mesquita do Instituto Histórico e Geográfico de São Paulo. Tese de Doutorado apresentada na FFLCH da Universidade de São Paulo, 1975.

. "Por um modelo de formação arquivística". In:

Ciências e letras. Porto Alegre, nº 31, jan- jun 2002.

CAMARGO, Ana Maria de Almeida, BELlOTTO, Heloisa Liberalli (coord.). Dicionário de terminologia arquivística. São Paulo, AAB-SP/SEC, 1996.

CAMARGO, Célia. "O uso acadêmico e científico dos arquivos". In: Arquivo: boletim histórico e informativo. São Paulo, v.10, nº 2, jul/dez 1989.

CAMARGO, Haroldo Leitão. Patrimônio histórico e cultural. São Paulo, Editora Aleph, 2002.

CAMPOS, Candido Malta. Os rumos da cidade. Urbanismo e modernização em São Paulo. São Paulo, Senac, 2002.

CANCLINI, Néstor Garcia. Culturas híbridas. São Paulo, Edusp, 2006.

CÂNDIDO, Antônio. Formação da literatura brasileira: 1750- 1836. Belo Horizonte, Itatiaia, 1975.

CARONE, Edgard. A evolução industrial de São Paulo (1889- 1930). São Paulo, Editora SENAC, 2001.

CARR, Edward Hallet. Que é história. Rio de Janeiro, Editora Paz e Terra, 2002.

CARVALHO, José Murilo de. A construção da ordem. A elite política imperial. Brasília, UnB, 1981. 
CARVALHO, Roberto Machado. "A fundação do IHGSP- os idealizadores e a sessão inaugural". In: Revista do Instituto Histórico e Geográfico de São Paulo. São Paulo, vol. 88, 1993.

CASTILHO, Ataliba Teixeira (org.). A sistematização de arquivos públicos. Campinas, Unicamp, 1991.

CERTEAU, Michel. A escrita da história. Rio de Janeiro, Forense Universitária, 2006.

CHOAY, Françoise. A alegoria do patrimônio. São Paulo, Estação Liberdade/ Editora da Unesp, 2001.

COSTA, Luiz Augusto Maia. O ideário urbano paulista na virada do século. $O$ engenheiro Theodoro Sampaio a as questões territoriais e urbanas modernas (1886- 1903). São Paulo, Dissertação de Mestrado defendida na Faculdade de Arquitetura e Urbanismo da Universidade de São Paulo, 2001.

CORDEIRO, Helena Kohn. O centro da metrópole paulistana. Expansão recente. São Paulo, Vozes, 1980.

DEBES, Célio. "A revista do Instituto Histórico e Geográfico de São Paulo e a pesquisa histórica". In: Revista do Instituto Histórico e Geográfico de São Paulo. São Paulo. São Paulo, vol. 88, 1993.

DE MASI, Domenico (org.). A emoção e a regra. Os grupos criativos na Europa de 1850 a 1950. Rio de Janeiro, José Olympio, 1999.

DERBY, Orville A. Limites entre São Paulo e Minas Gerais. São Paulo, Typographia Brazil, 1920.

DIAS, Maria Odila Leite da. Quotidiano e sobrevivência em São Paulo no séc. XIX. São Paulo, Brasiliense, 1995.

DONATO, Hernani. “A cidade de São Paulo em 1894”. In: Revista do Instituto Histórico e Geográfico de São Paulo. São Paulo, vol. 88, 1993.

DUCHEIN, Michel. "O respeito aos fundos em arquivística: princípios teóricos e problemas práticos”. In: Arquivo \& administração. Rio de Janeiro, vol. 10- 14, n 1 , abril 1982/agosto 1986. 
FERREIRA, Antônio Celso. A epopéia paulista: imaginação literária e invenção histórica (1870- 1940). Tese de Livre Docência defendida no Departamento de História da Unesp de Assis, 1999.

FERRETTI, Danilo José Zioni. A construção da paulistanidade. Identidade, historiografia e política em São Paulo (1856- 1930). São Paulo, Tese de Doutorado defendida no Departamento de História da Faculdade de Filosofia, Letras e Ciências Humanas da Universidade de São Paulo, 2004.

FERRO, Marc. A manipulação da história no ensino e nos meios de comunicação. São Paulo, Ibrasa, 1983.

FIGUEIRÔA, Silvia Fernanda de Mendonça. Os modernos bandeirantes: a Comissão Geográfica e Geológica de São Paulo e a exploração científica do território paulista (1886-1931). São Paulo, Dissertação de Mestrado defendida no Departamento de História da Faculdade de Filosofia, Letras e Ciências Humanas da Universidade de São Paulo, 1987.

FLEIUSS, Max. O Instituto Histórico através de sua Revista. Rio de Janeiro, Imprensa Nacional, 1938.

FLEXOR, Maria Helena Ochi. Abreviaturas: manuscritos dos séculos XVI ao XIX. São Paulo, AESP/ Editora Unesp, 1991.

GAGLIARDI, Pedro L. R. e ALMEIDA, Wilson C.F. Lopes de. Arquivos judiciários. São Paulo, Edições Arquivo do Estado, 1985.

GLÉNISSON, Jean. Introdução aos estudos históricos. São Pualo, DIFEL, 1961.

GUIMARÃES, José Augusto Chaves; NASCIMENTO, Lúcia Maria Barbosa do; NETO, Mario Furlaneto. Aspectos jurídicos e diplomáticos dos documentos eletrônicos. São Paulo, Arq- SP, 2005.

HERRERA, Antonia Heredia. El principio de procedencia y los otros principios de la archivística. São Paulo, Arq- SP, 2003.

HOBSBAWM, Eric; RANGER, Terence. A invenção das tradições. Rio de Janeiro, Paz e Terra, 1997. 
HOLANDA, Sérgio Buarque de. Leopold von Ranke: história. São Paulo, Ática, 1979.

HOLlOWAY, Thomas H. Imigrantes para o café. Rio de Janeiro, Paz e Terra, 1984.

IHGB. Revista do Instituto Histórico e Geográfico Brasileiro. Rio de Janeiro, Companhia Tipográfica do Brasil, 1896, tomo 59, $2^{\text {a }}$ parte.

IHGSP. Revista do Instituto Histórico e Geográfico de São Paulo. São Paulo, IHGSP, 1895- 1993.

INSTITUTO FERNANDO HENRIQUE CARDOSO. Documentos privados de interesse público: o acesso em questão. São Paulo, IFHC, 2004.

JANCSÓ, István. Brasil: formação do estado e da nação. São Paulo, Hucitec, 2003.

JENKINS, Keith. A história repensada. São Paulo, Contexto, 2004.

JOUTARD, Philippe. "Memória e identidade nacional: o exemplo dos Estados Unidos e da França". In: AZEVEDO, Cecília (org.) et al. Cultura política, memória e historiografia. Rio de Janeiro, FGV, 2009.

KARNAL, Leandro; TATSCH, Flavia Galli. "Documento e história: a memória evanescente". In: PINSKY, Carla Bassanezi e LUCA, Tania Regina de. $O$ historiador e suas fontes. SP, Contexto, 2009.

LACOMBE, Américo Jacobina; SILVA, Eduardo; BARBOSA, Francisco de Assis. Rui Barbosa e a queima dos arquivos. Rio de Janeiro, Fundação Casa de Rui Barbosa, 1988.

LAMEGO, Alberto Ribeiro. Orville Adelbert Derby, 1851-1951; alguns aspectos da sua obra. Rio de Janeiro, Departamento Nacional Produção Mineral, 1951.

LANGLOIS, Charles; SEIGNOBOS, Charles. Introdução aos estudos históricos. São Paulo, Editora Renascença, 1946.

LARA, Silvia Hunold. "História, memória e museu". In DEPARTAMENTO DO PATRIMÔNIO HISTÓRICO. Revista do Arquivo Municipal. São Paulo, DPH, vol. 200, 1991. 
LEFEBVRE, Henri. La presencia y la ausencia. Contribución a la teoria de las representaciones. México, Fondo de Cultura Económica, 1983.

LE GOFF, Jacques. História e memória. Campinas, Editora da Unicamp, 2003.

LINHARES, Maria Yedda; SILVA, Francisco Carlos Teixeira da. Terra prometida. Uma história da questão agrária no Brasil. Rio de Janeiro, Campus, 1999.

LOPES, Eliane Marta Teixeira (org.). 500 anos de educação no Brasil. Belo Horizonte, Autêntica, 2000.

LOPES, Luis Carlos. A gestão da informação: as organizações, os arquivos e a informática aplicada. Rio de Janeiro, APERJ, 1997. . A imagem e a sombra da arquivística. Rio de Janeiro, Arquivo Público do Estado do Rio de Janeiro, 1998.

LOPEZ, André Porto Ancona. Tipologia documental de partidos políticos e associações políticas brasileiras. São Paulo, Loyola, 1999. . As razões e os sentidos. São Paulo, Tese de Doutorado defendida no Departamento de História da Faculdade de Filosofia, Letras e Ciências Humanas da Universidade de São Paulo, 2000.

- Como descrever documentos de arquivo: elaboração de instrumentos de pesquisa. São Paulo, AESP/ Imesp, 2002.

MARTINS, Ana Luiza. "Fontes para o patrimônio cultural: uma construção permanente". In: PINSKY, Carla Bassanezi e LUCA, Tania Regina de. $O$ historiador e suas fontes. SP, Contexto, 2009.

MARTINS, José de Souza (org.). Henri Lefebvre e o retorno à dialética. São Paulo, Hucitec, 1996.

MATOS, Odilon Nogueira de. Café e ferrovias. São Paulo, Alfa-Ômega, 1974. . Afonso de Taunay, historiador de São Paulo e do Brasil: perfil biográfico e ensaio bibliográfico. São Paulo, Universidade de São Paulo, Fundo de Pesquisas do Museu Paulista, 1977. 
MATTOS, Claudia V. de. "Imagem e palavra". In: OLIVEIRA, Cecília Helena de Salles; MATTOS, Claudia Valladão de (org.). O brado do Ipiranga. São Paulo, Edusp/ Museu Paulista, 1999.

MENESES, Ulpiano T. Bezerra de. "A cultura material no estudo das sociedades antigas". In: Revista de história. São Paulo, nº 115, jul- dez., 1983.

. "Memória e cultura material: documentos pessoais no espaço público". In: Estudos históricos. Rio de Janeiro, vol. 11, nº 21, 1998. . "Cultura política e lugares de memória". In:

AZEVEDO, Cecília (org.) et al. Cultura política, memória e historiografia. Rio de Janeiro, FGV, 2009.

NEPS. Guia dos documentos históricos da cidade de São Paulo. São Paulo, Hucitec, 1998.

NISKIER, Arnaldo. Educação brasileira: 500 anos de história (1500-2000). Rio de Janeiro, Consultor, 1995.

NOVAES, Adauto (org.). Tempo e história. São Paulo, Companhia das Letras/ Secretaria Municipal de Cultura, 1992.

OLIVEIRA, Cecília Helena de Salles; MATTOS, Claudia Valladão de (org.). $O$ brado do Ipiranga. São Paulo, Edusp/ Museu Paulista, 1999.

OLIVEIRA, José da Veiga. "A expressão musical de São Paulo- fins do séc. XIXmúsica erudita". In: Revista do Instituto Histórico e Geográfico de São Paulo. São Paulo, vol. 88, 1993.

OLIVEIRA, José Joaquim Machado d'. Geografia da província de São Paulo adaptada à lição das escolas e oferecida à Assembléia Legislativa provincial. São Paulo, Tipografia Imparcial, 1862.

- Quadro histórico da província de São

Paulo. São Paulo, Governo do Estado, 1978.

OLIVEIRA, Lucia Lippi. O Brasil dos imigrantes. Rio de Janeiro, Jorge Zahar Editora, 2001.

PAES, Marilena Leite. Arquivo: teoria e prática. Rio de Janeiro, FGV, 2002. 
PAIVA, Odair da Cruz. Caminhos cruzados: migração e construção do Brasil moderno (1930- 1950). Bauru, EDUSC, 2004.

. "Diferentes tempos de uma mesma história". In:

CAMARGO, Ana Maria de Almeida. São Paulo: uma viagem no tempo. São Paulo, CIEE, 2005

PALUMBO, Maria Rita. "Bom gosto e bom senso na produção em série: a Casa Thonet”. In: DE MASI, Domenico (org.). A emoção e a regra. Os grupos criativos na Europa de 1850 a 1950. Rio de Janeiro, José Olympio, 1999.

PAOLI, Maria Célia. "Memória, história e cidadania: o direito ao passado". In: DEPARTAMENTO DO PATRIMÔNIO HISTÓRICO. O direito à memória: patrimônio histórico e cidadania. São Paulo, DPH, 1992, pp. 25-28.

PESCHANSKI. Catherine Darbo. "Os tempos da história”. In: NOVAES, Adauto (org.). Tempo e história. São Paulo, Companhia das Letras/ Secretaria Municipal de Cultura, 1992.

PETRONE, Maria Thereza Schorer. O imigrante e a pequena propriedade. São Paulo, Brasiliense, 1982.

PIMENTA, Jose de Melo. No instituto histórico e geográfico de São Paulo. São Paulo, S.N., 1959.

PINHEIRO, José Feliciano Fernandes. Anais da província de São Paulo. Rio de Janeiro, Imprensa Nacional, 1946.

PINSKY, Carla Bassanezi (org.). Fontes históricas. São Paulo, Contexto, 2005.

PINSKY, Carla Bassanezi e LUCA, Tania Regina de. O historiador e suas fontes. SP, Contexto, 2009.

PIZA, Antônio de Toledo. Questões de divisas entre São Paulo e Minas Gerais. São Paulo, Tipografia do Correio Paulistano, 1898.

PRADO JR, Caio. Evolução política do Brasil colônia e império. São Paulo, Brasiliense, 1989.

. Formação do Brasil contemporâneo. São Paulo, Brasiliense, 1996. 
PUNTONI, Pedro. "O Sr. Varnhagen e o patriotismo caboclo: o indígena e o indianismo perante a historiografia brasileira”. In: JANCSÓ, István (org.). Brasil: formação do estado e da nação. São Paulo, Hucitec, 2003.

RODRIGUES, José Honório. "A liberdade de informação e pesquisa”. In: Arquivo \& Administração. Rio de Janeiro, 6(3):5-11, dez. 1976.

RODRIGUES, Ana Márcia Lutterbach. Uma análise da teoria dos arquivos. Dissertação de Mestrado apresentada na Escola de Ciência da Informação da Universidade Federal de Minas Gerais, 2004.

ROMERO, Mariza. Medicalização da saúde e exclusão social. Bauru, EDUSC, 2002.

RONDINELLI, Rosely Curi. Gerenciamento arquivístico de documentos eletrônicos. Rio de Janeiro, FGV, 2002.

ROWLAND, Robert. "Patriotismo, povo e ódio aos portugueses: notas sobre a construção da identidade nacional no Brasil independente". In: JANCSÓ, István. Brasil: formação do estado e da nação. São Paulo, Hucitec, 2003.

SALIBA, Elias Thomé. "Pequena história dos documentos: aventuras modernas e desventuras pós-modernas". In: PINSKY, Carla Bassanezi e LUCA, Tania Regina de. O historiador e suas fontes. SP, Contexto, 2009.

SALLES, Alberto. A pátria paulista. Brasília, Editora da UnB, 1983.

SANTANA, Nuto. São Paulo histórico: aspectos, lendas e costumes. São Paulo, Departamento de Cultura, 1937.

SCHELLENBERG, Theodore R. Documentos públicos e privados: arranjo e descrição. Rio de Janeiro, FGV, 1974.

. Arquivos modernos: princípios técnicos. Rio de

Janeiro, FGV, 2002.

SCHLOSSER, Julius Von. Las cámaras artísticas y maravillosas del renascimento tardío. Una contribuición a la historia del coleccionismo. Madri, Akal, 1988.

SEVCENKO, Nicolau. "Incursões na entropia paulista". In: CAMARGO, Ana Maria de Almeida. São Paulo: uma viagem no tempo. São Paulo, CIEE, 2005. 
SILVA, Lígia Osório. Terras devolutas e latifúndio. Os efeitos da lei de 1850. Campinas, Unicamp, 1996.

SILVA, Maria Beatriz Nizza da (org.). História de São Paulo colonial. São Paulo, Editora da Unesp, 2009.

SILVA Sérgio. Expansão cafeeira e origens da indústria no Brasil. São Paulo, AlfaÔmega, 1976.

SILVA, Zélia Lopes (org). Arquivos, patrimônio e memória. Trajetórias e perspectivas. São Paulo, Editora da Unesp/ Fapesp, 1999.

SIRIANI, Silvia Cristina Lambert. Uma São Paulo alemã: vida quotidiana dos imigrantes germânicos na região da capital (1827- 1889). São Paulo, Arquivo do Estado/ Imesp, 2003.

SLENES, Robert W. "Escravos, cartórios e desburocratização: o que Rui Barbosa não queimou será destruído agora?”. In: Revista Brasileira de História, São Paulo, 5(10):166-196, 1985.

THOMPSON, E. P. Senhores e caçadores: a origem da lei negra. Rio de Janeiro, Paz e Terra, 1987.

VAIFAS, Ronaldo (org.). Dicionário do Brasil imperial. Rio de Janeiro, Objetiva, 2002.

VIANNA, Francisco José de Oliveira. Ensaios inéditos. Campinas, Unicamp, 1991.

VESENTINI, Carlos Alberto. A teia do fato. São Paulo, Hucitec, 1997.

WITTER, José Sebastião. Arquivo e história. O Arquivo do Estado de São Paulo na administração e na história. Tese de Livre Docência apresentada na FFLCH da Universidade de São Paulo, 1981. 


\begin{abstract}
ANEXO I
Relação de títulos dos Documentos interessantes

(ver Banco de Dados)
\end{abstract}




\title{
ANEXO II
}

\section{Relação de títulos do Boletim do Departamento do Arquivo do}

\author{
Estado de São Paulo
}

\begin{tabular}{|c|c|c|}
\hline Vol. I & $\begin{array}{c}\text { Maço 1 (Tempo Colonial): 1722- 1822 } \\
\text { Cartas e certidões diversas, representações e justificações, almoxarifado e alfândega } \\
\text { de Santos }\end{array}$ & 1942 \\
\hline Vol. II & $\begin{array}{c}\text { Maço } 1 \text { (Tempo Colonial): 1722- } 1822 \text { (continuação) } \\
\text { Termos diverso, certidões, vistorias, alfândega e almoxarifado de Santos } \\
\text { Tempo Imperial: criação da vila de Jacareí e instalação da de São João de Capivari, } \\
\text { papel inimitável, iluminação da capital, auto de instalação da vila de Caconde }\end{array}$ & 1943 \\
\hline Vol. III & $\begin{array}{l}\text { Maço 1 (Tempo Colonial): 1722- } 1822 \text { (continuação) } \\
\text { Tempo Imperial: a bandeira de Joaquim Francisco Lopes }\end{array}$ & 1943 \\
\hline Vol. IV & $\begin{array}{l}\text { Maço } 1 \text { (Tempo Colonial): 1722- } 1822 \text { (continuação) } \\
\text { Alfândega e almoxarifado de Santos }\end{array}$ & 1943 \\
\hline Vol. V & $\begin{array}{l}\text { Maço } 2 \text { (Tempo Colonial): 1721- } 1804 \\
\text { Aldeamento de índios } \\
\text { Documentos avulsos: doação do terreno para a fundação da vila de Ubatuba (1640) }\end{array}$ & 1945 \\
\hline Vol. VI & $\begin{array}{c}\text { Esclarecimentos sobre o tempo do governo Oeynhausen em São Paulo, histórico e } \\
\text { notas de São Carlos, Capivari, Salesópolis, Santo Amaro, Minas do Iporanga, } \\
\text { Conselheiro Carrão e Jaú }\end{array}$ & 1946 \\
\hline Vol.VII & $\begin{array}{l}\text { Maço } 2 \text { (Tempo Colonial): 1721- } 1804 \\
\text { Aldeamento de índios (continuação) }\end{array}$ & 1947 \\
\hline Vol. VIII & $\begin{array}{l}\text { Maço } 2 \text { (Tempo Colonial): 1721- } 1804 \\
\text { Aldeamento de índios (conclusão) }\end{array}$ & 1948 \\
\hline Vol. IX & $\begin{array}{c}\text { Nova fase } \\
\end{array}$ & 1952 \\
\hline Vol. X & Artigos diversos & 1953 \\
\hline Vol. XI & Artigos diversos & 1953 \\
\hline Vol. XII & Artigos diversos & 1953 \\
\hline Vol. XIII & Artigos diversos & 1954 \\
\hline Vol. XIV & Artigos diversos & 1955 \\
\hline Vol. XV & $\begin{array}{l}\text { Atas do Conselho da Presidência da Província de São Paulo (1829) } \\
\text { Continuação dos Documentos interessantes, vol. LXXXVI }\end{array}$ & 1961 \\
\hline Vol. XVI & $\begin{array}{l}\text { Atas do Conselho da Presidência da Província de São Paulo (1832- 4) } \\
\text { Continuação dos Documentos interessantes, vol. LXXXVI }\end{array}$ & 1962 \\
\hline
\end{tabular}




\section{ANEXO III}

Base de dados com todos os registros dos Documentos interessantes (ver Banco de Dados) 